Historic, Archive Document

Do not assume content reflects current scientific knowledge, policies, or practices. 


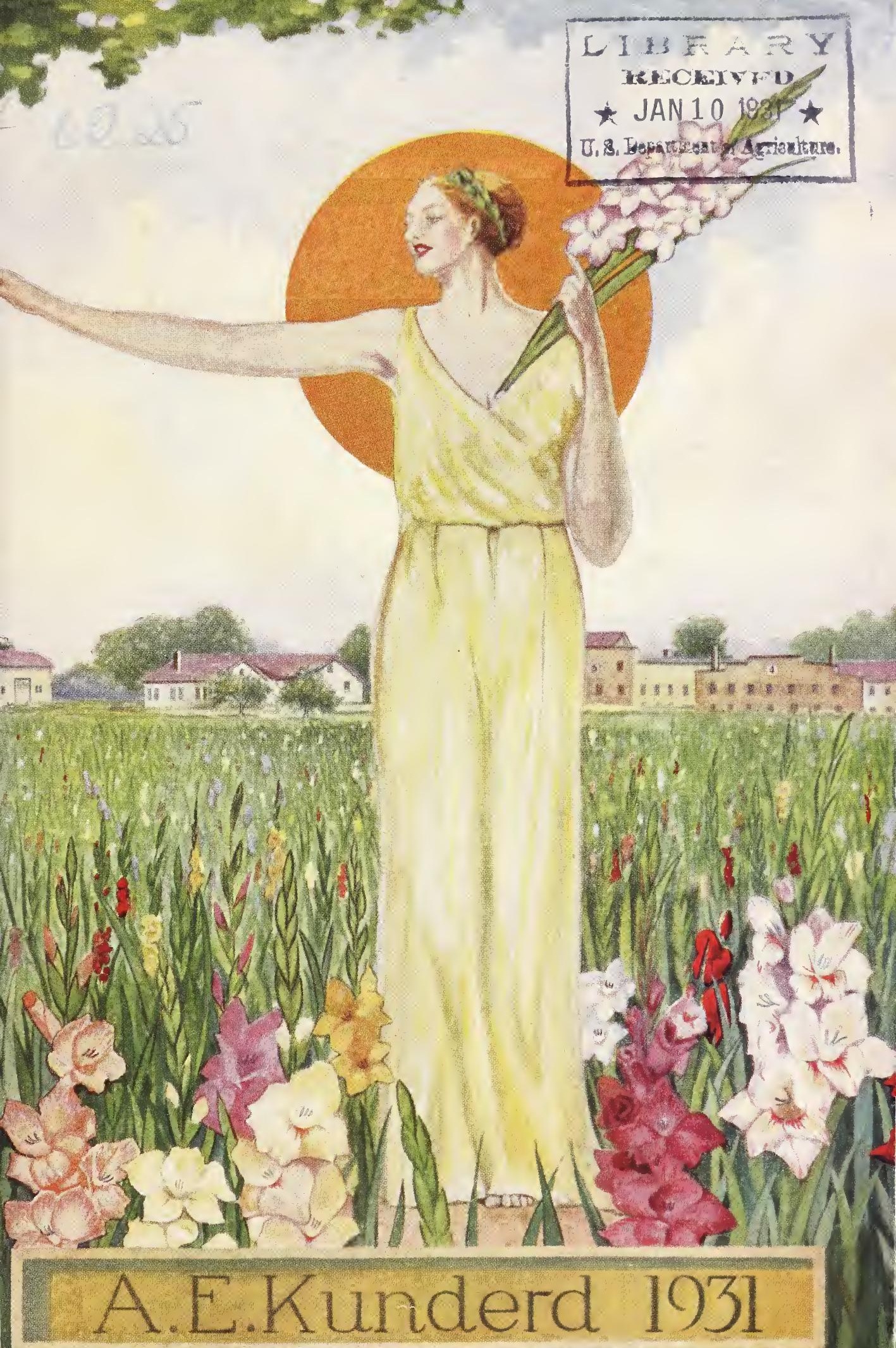

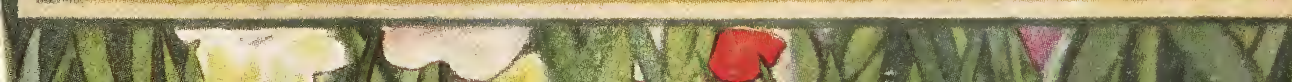




\section{Typical Kunderd Beauties}

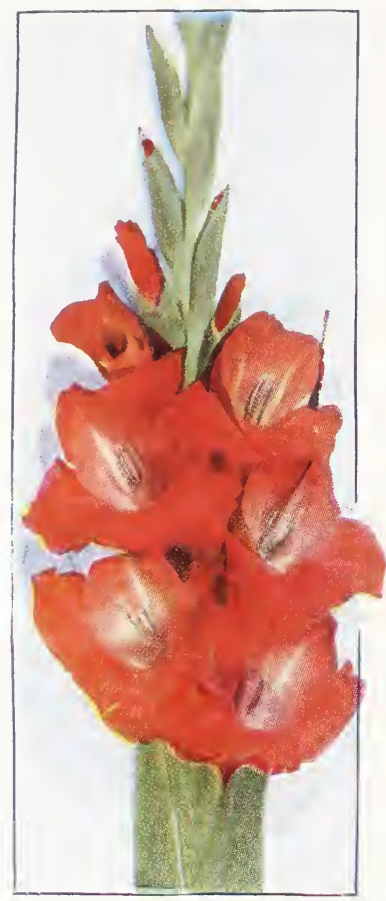

Chas. F. Fairbanks

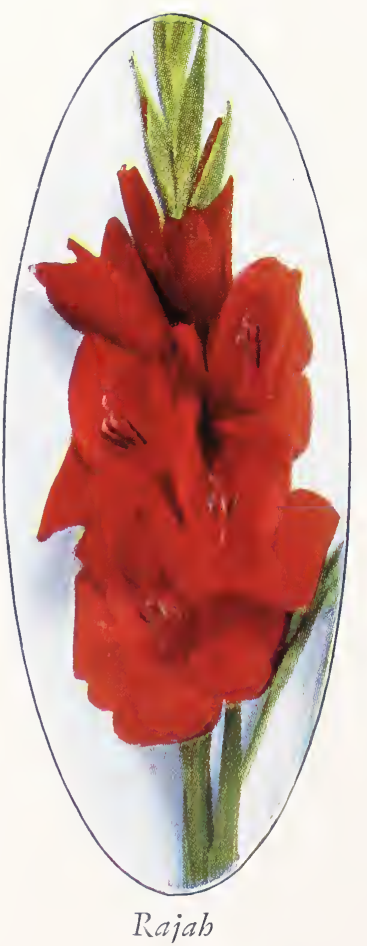

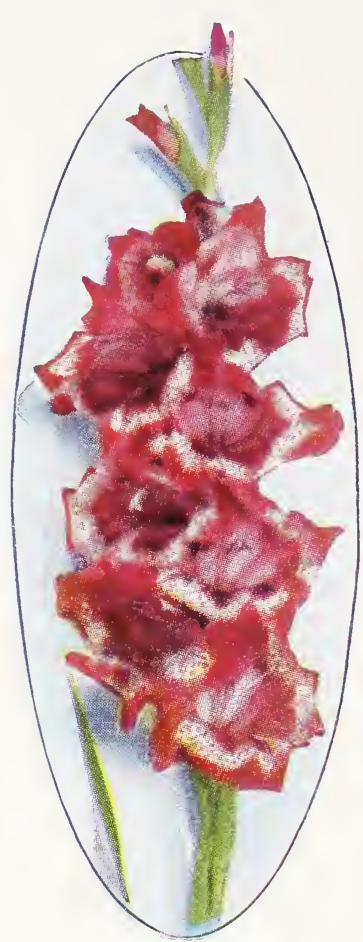

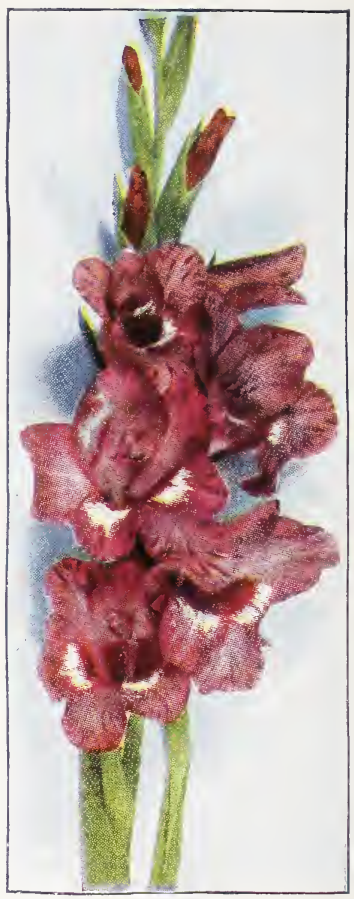

Tiger

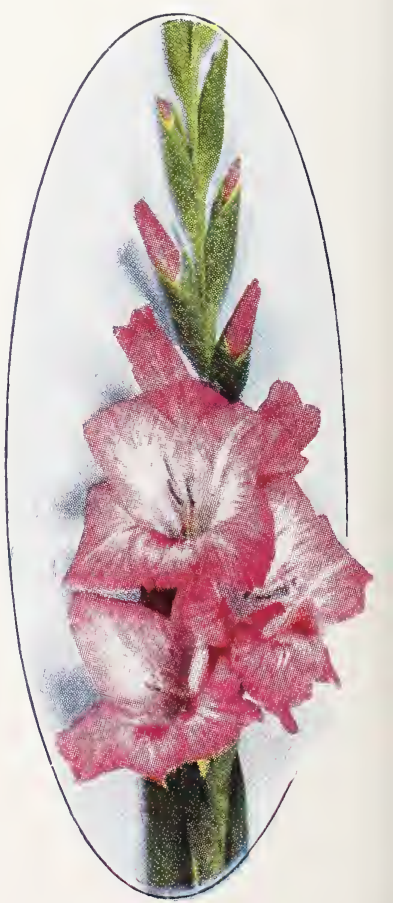

Highland Laddie

Favorite 


\section{Did You Ever Sit On Top of a Hill?}

$\mathrm{C}_{\mathrm{T}}$ Is a boyish thing to do, to watch the clouds roll by and wonder what is far beyond. My youthful vision I can recall as vividly today as when it first came before my eyes, fifty years ago. It was the dream of youth, of hope, of inspiration. It was a dream that has carried me toward the loftiest pinnacles of achievement. As I looked from the petals of the first gladiolus I had ever seen into the azure blue of the heavens I could see a marvelous field of these magnificent flowers. The sight was more than my youthful mind could comprehend, it was like a mirage, yet I followed the beckoning of the Goddess of Achievement. Beauty, perfection and realism were indelibly fixed upon my mind and that dream has really come true. The realization of that dream has made me very happy because in every civilized country flower lovers are sharing with me the privilege of enjoying my flowers. How my vision became a reality I will attempt to tell in the following pages and $I$ trust it may serve as an inspiration to the youth of today to follow the inclinations of his inner self.
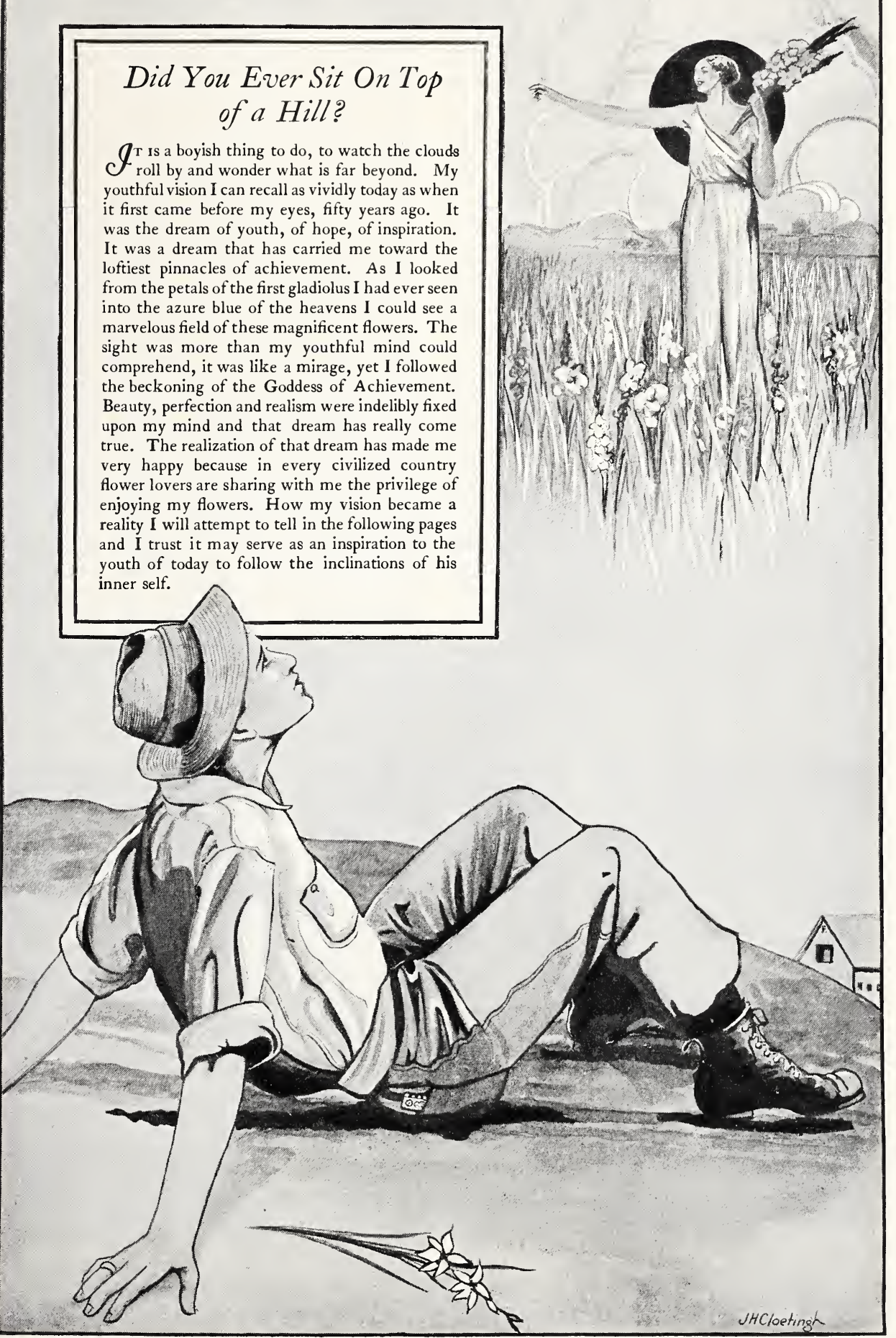


\section{Why KUNDERD Gladioli Stand Supreme}

A BOUT the year of 1880 I had the $A$ pleasure and the satisfaction of seeing the first Gladiolus. I have often repeated that my inspiration came from the beauty of this flower. There was something about the gladiolus that immediately won my admiration and for over fifty years I have devoted most all of my time producing and developing new strains. Today, I am as fond of the gladiolus as ever and I find as much interest in my breeding work as at any time during my lifetime. What has been accomplished and how, is information I will give you as accurately and briefly as possible.

Many flower lovers are of the impression that it is a difficult thing to produce gladioli from seed and that it is difficult to make crosses in order to obtain new seedlings. Such is not the case, the process is comparatively simple and I am quite sure that anyone can accomplish the task once it has been explained to them. Many of my friends have expressed themselves as being amazed that I am able to produce so many seedlings little realizing that this is a very trivial part of my work of plant breeding.

It would not be difficult to raise a few good horses, most anyone with a fair understanding of animals can do that but it is another matter to produce a "Man of War" or a "Blue Larkspur." These horses have earned fame for their owners and breeders because they are the fleetest and best. They are thoroughbreds and a most thorough knowledge of line breeding was necessary to produce them. The same holds true with flowers and plant life. One must study carefuliy the parentage and know the characteristics of the progeny.

The breeding of flowers is exactly the same as the breeding of animals. One must have the finest blood lines in order to obtain excellent results. This does not mean that two excellent horses will produce excellent offspring. On the contrary, very ordinary colts may result from such unions. The blood of these two animals may be entirely wrong for good results and for good breeding. That is the real problem of the breeder, he must know what crosses to make and this requires many years of constant study.

The process of flower and plant breeding is very slow, much slower than the breeding of animals. Early in my gladiolus breeding experience I noticed in some varieties a tendency to ruffling. This showed up along the edges of the petals of the flowers. It was a very beautiful effect but not sufficiently pronounced. For twenty-two years I experimented making crosses of my finest kinds with species having slightly ruffled petals in their native form. I made crosses always with the idea of

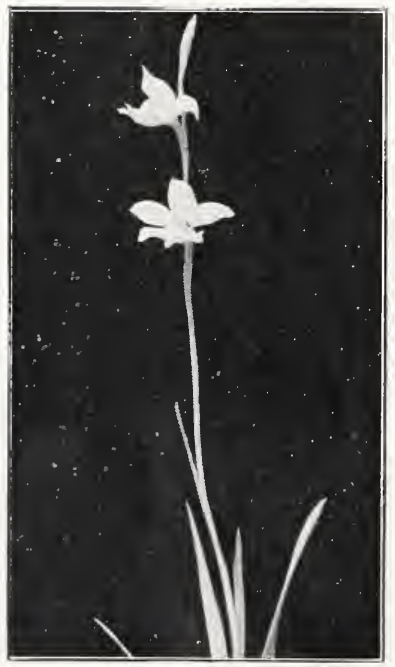

Wild Species

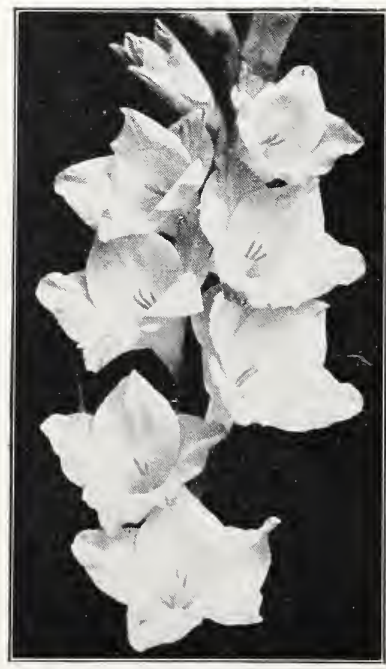

An Early Type

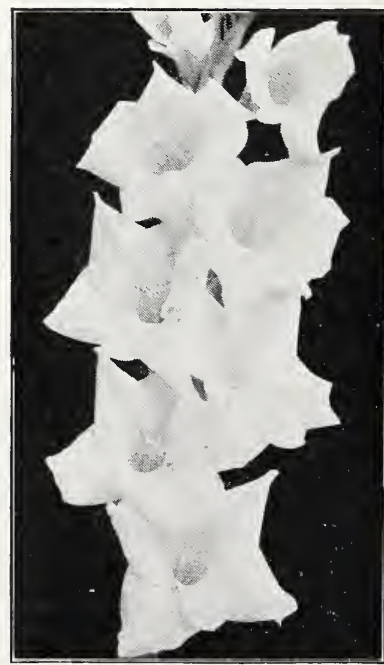

Type Preceding Kunderd Gladioli

These pictures illustrate only a few of the extreme types found along the lines of improvement in Gladioli.

See Special Collection Offers. Pages 15, 21, 30, 35, 47, 74, 75, 81, 83 
producing a ruffled type of gladiolus. In 1908 I introduced the "Man of War" of the Gladiolus Kingdom, the first ruffled gladiolus, Kunderdii Glory. It took many years to produce the first ruffled gladiolus scientifically. Many years of hard study, hard work and many disappointments but finally success. The ruffled gladioli, which I originated, have obtained remarkable popularity and are now to be found in millions of gardens throughout the entire civilized world. It has become one of the most loved flowers of the summertime.

In the breeding of flowers there are things to be considered other than beauty, such as vigor, size, formation of the flowers, ease of culture, permanency of color and adaptability to the florist trade.

Each presents its problem to the breeder, and it must be clearly understood that it requires many years of my time and utmost patience. In many instances I have toiled for fifteen years on a certain type of flower endeavoring to produce a new color or shape only to find that the variety lacks in certain characteristics. After all these years I often abandon my work with these varieties and start all over again. It is only the varieties that have all the desired features combined that ever find a place in my catalog, and while you spend a few moments reading the names and descriptions in this book, bear in mind that many years were required to produce them.

In over fifty years of plant breeding it has been my constant effort to pro- duce always something new, something better-distinctiveness in beautiful and narmonious color combination: more sturdy plant growth; more stately blooms, greater productivity: new types with better qualities throughout are always necessiry in the production of new and better originations.

It has been a reward in itself to see so many of my varieties put at the top of the list known as "the best" by those whose judgment is final, whose approval and favor I always strive to attain-the ultimate user-the flower loving public.

In order that you may have a more definite understanding of the care and skill exercised in producing Kunderd Gladioli let me take you briefly through the system employed on my farms.

Let us go into my trial grounds, by far the largest gladiolus trial grounds in the world. This is none other than my workshop for here are the new productions that are to carry on the name of Kunderd and give pleasure to my patrons. They are unnamed as yet but among them will be found the great new productions of future years. There are four outstanding types in this magnificent panorama of color-the Ruffled and Plain petalled, the Laciniated and the Kunderd Primulinus Hybrids. In each of these classes are thousands of varieties. Year after year, they are grown in our trial beds for observation until they have proven themselves to be worthy of introduction or are discarded. Only the choicest ones find their way into my catalog.

The gladiolus varieties you find listed

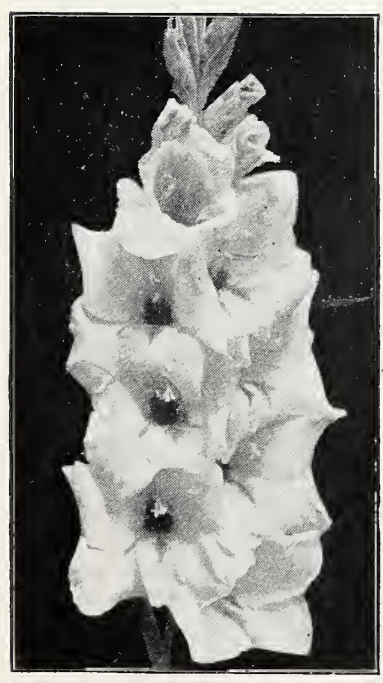

Early Kunderd Variety It must be understood that

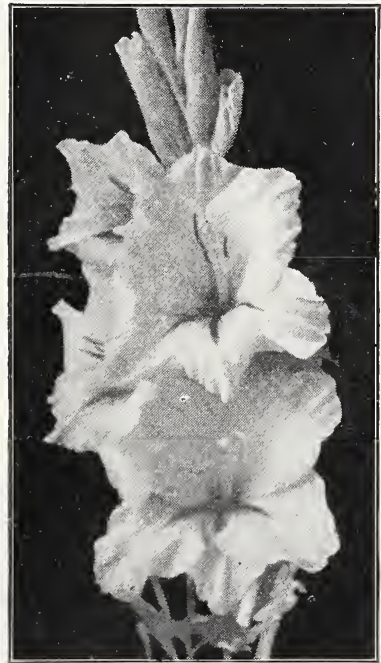

Early Ruffed Variety

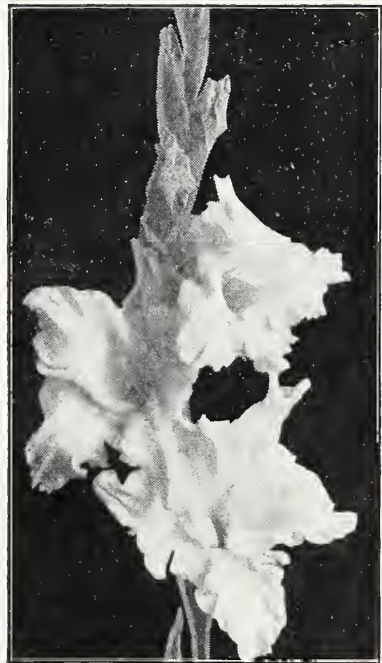

Newest Ruffed Type A. E. Kunderd, Goshen, Indiana 
are the kinds that are the result of extraordinary care and scientific breeding. In other words, they have stood the test and have reached their high standard of excellence and perfection and have won world-wide recognition as the best.

I want to take you through each step in the manufacture of my flowers and bulbs, as it were, that you may fully realize why "Kunderd Gladioli Stand Supreme."

After careful observation of weather conditions in the springtime and when all danger of frost has passed, the bulbs are planted in carefully prepared soil best suited for gladiolus production. More than seventy-five acres are devoted to my plantings and as I use the same ground only once in four years or more, hundreds of acres of choice land are required for proper rotation and highest quality of bulb production. All my bulbs are hand planted by thoroughly experienced help and this is done for the reason no other method is as good as hand planting. Almost fifty per cent of the entire weeding is done by hand. During the entire growing season my gladioli are free from weeds as I keep a crew of men constantly in the field for this purpose.

After the spikes are partly bloomed out the flowers are cut below the first blooms in order to produce the best possible bulb development. All during the growing season cultivation never ceases and when the bulbs are taken from the ground they are as nearly perfect as efficient care and culture can make them.

The next step, and a most important

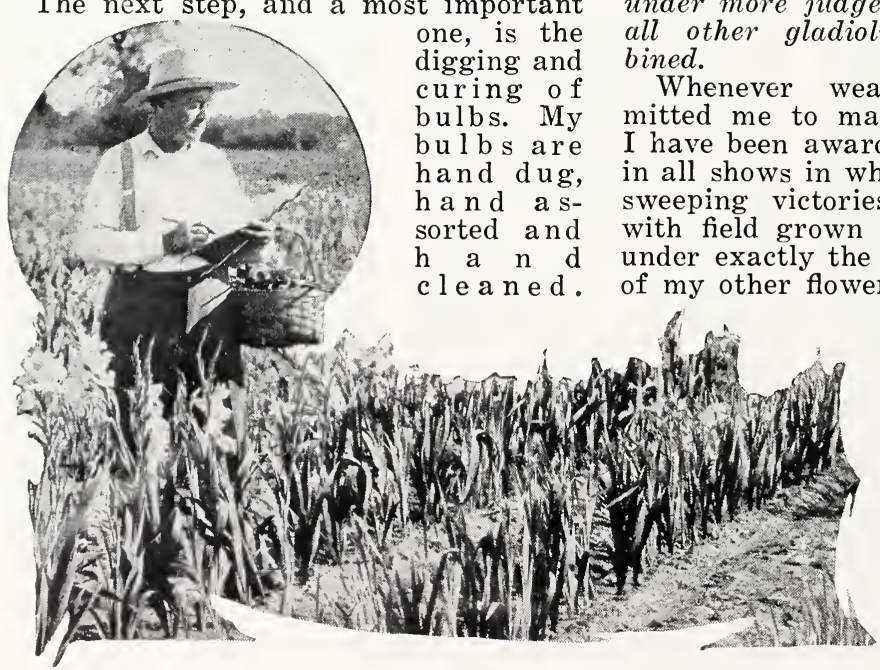
digging and curing of bulbs. My bulbs are and $\mathrm{dug}$ They are placed in flats or crates and removed from the field to the most perfect drying room possible. After they become sufficiently dry they are run under electric suction cleaners which remove all surplus dust and soil. After

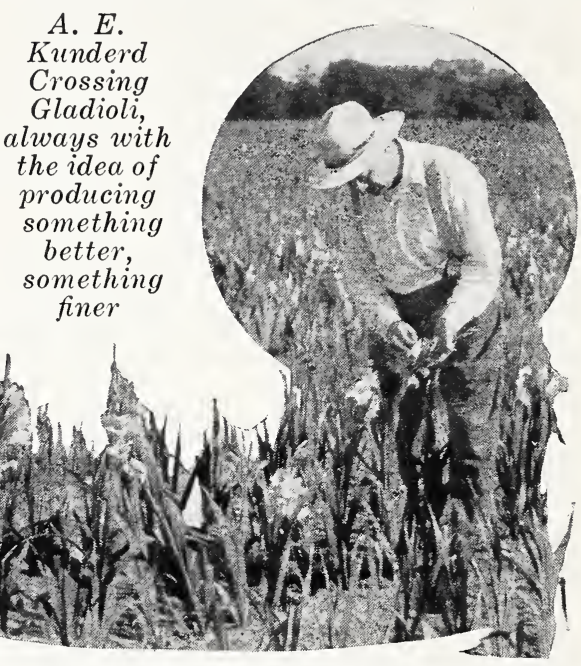

this has been done each bulb is gone over by hand by workmen who are skilled and have been in my employ for a great many years. Following the hand cleaning process they are stacked, still in their carefully labelled crates, to the final curing rooms. Humidity, temperature, circulation and watchfulness are necessary, for the curing of the bulbs is of utmost importance.

I have given you a few of the reasons why "Kunderd Gladioli Stand Supreme" and I sight as proof the fact that $K u n$ derd Gladioli have won more times, under more judges, in more shows than all other gladioli in the world combined.

Whenever weather conditions permitted me to make a complete exhibit I have been awarded the highest honors in all shows in which I competed. These sweeping victories were made entirely with field grown stocks, gladioli grown under exactly the same conditions as all of my other flowers. My record of leadership in the Gladiolus world stands unchallenged.

\section{A. E. Kunderd Describing His New Varieties in the Field and Making a Permanent Record}




\section{Endless Uses of the Gladiolus}

THE Gladiolus has become recognized 1 as the foremost all-around flower. There is nothing strange or phenomenal about this at all, because there are so many contributing factors to make it popular and versatile. In the first place, it is a beautiful flower easily and quickly obtained. Bulbs planted in April give you flowers in July. In other words, Gladioli bloom in from seventy to ninety days. Flowers can be had quickly for every purpose, "from the cradle to the grave."

Bride's bouquets, the most delicate and most feminine of all floral pieces, are the most exquisite and lovely when made with the florets of the Gladiolus, and this contrasted with the huge magnificent spikes that burst forth into bloom in your garden gives you a comprehensive idea of what can be accomplished with this beautiful flower of the summertime.

The many uses of the Gladiolus have always impressed me, in fact, it is one of the things that influence me most greatly. A Gladiolus garden can be the envy of your neighborhood. The huge spikes of gorgeous flowers as well as the most dainty and the wide variation of colors makes a lasting impression of

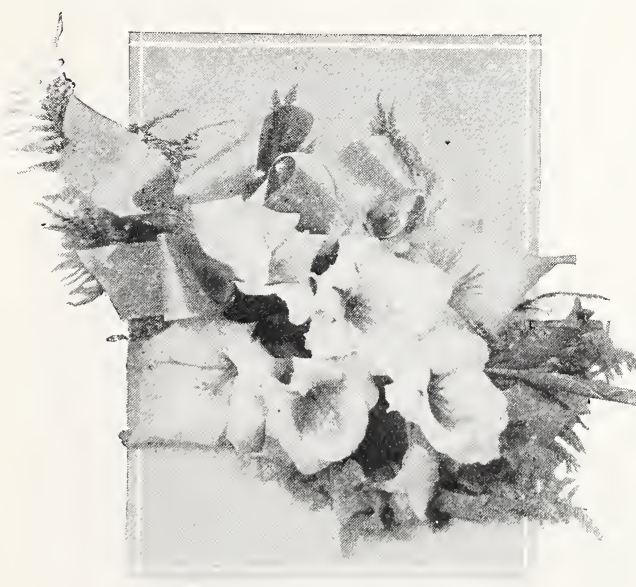

CHARMING CORSAGE BOUQUET

No flower excels the beautiful Gladioli for corsages. They are easily made by laying flat at slightly varied angles two or thrce sprays of ferns of various lengths and then arranging Gladioli tips and buds for best effect. Cover stems with two or three small ferns laid in opposite directions and tie with ribbon of appropriate color and size. Surprise your friends with these real, aristocratic little corsage favors when your Gladioli are in bloom next summer. This corsage was thc winner of first prize at a National Gladiolus show.

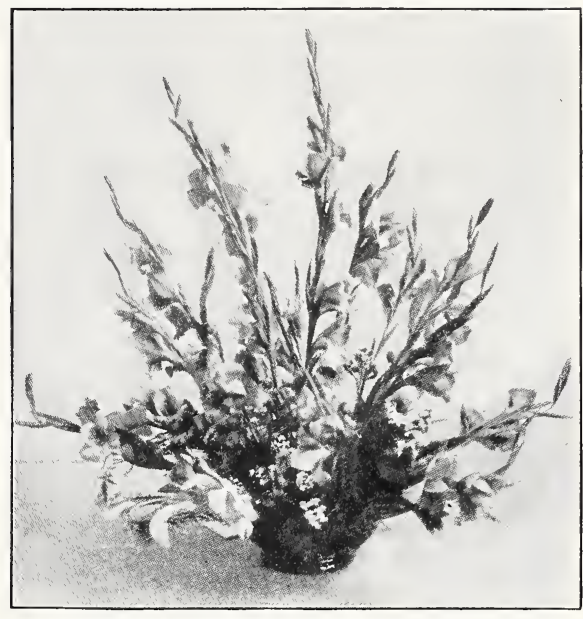

BEAUTIFUL TABLE DECORATION

For decorating the table it would be difficult to produce a morc beautiful effect than comes from Gladioli Tips in bowl. Here is shown my First Prize winning entry in this class in the National Gladiolus Show. It was awarded the A. G. S. Trophy.

beauty. Some varieties are smaller with a touch of femininity, others are large and masculine. Therefore Gladioli are found as frequently in men's club rooms as in the boudoir. Hotels, offices, hospitals, churches, stores, theatres, homes and public places are made bright and cheerful with the use of the Gladioli.

While Gladioli are especially adapted for vases, baskets, etc., they are used in an infinite number of ways. The tips can be taken from the spikes and made up into the most delightful plateau for your table. The florets also may be taken from the spikes and worked into the most artistic bowl effects. In the same fashion corsages can be made, and how beautiful and charming they are.

You will be surprised how easy it is to make up these enjoyable decorations with Gladioli. You will be surprised too how beautiful the effect, if you use with the Gladioli tiny sprays of asparagus or fern leaves, etc. There are so many variations of colors obtainable in Gladioli that you can obtain the most harmonious blendings. Whether you want a large bouquet of bold colors or a small bouquet of delicate colors Gladioli will serve you equally well. The delicate hues of an orchid, the beautiful markings of pansies, the blotches of the gloxinia, deep rich colors of the rose and the charm of the lily are all present among the many vari-

\section{A. E. Kunderd, Goshen, Indiana}




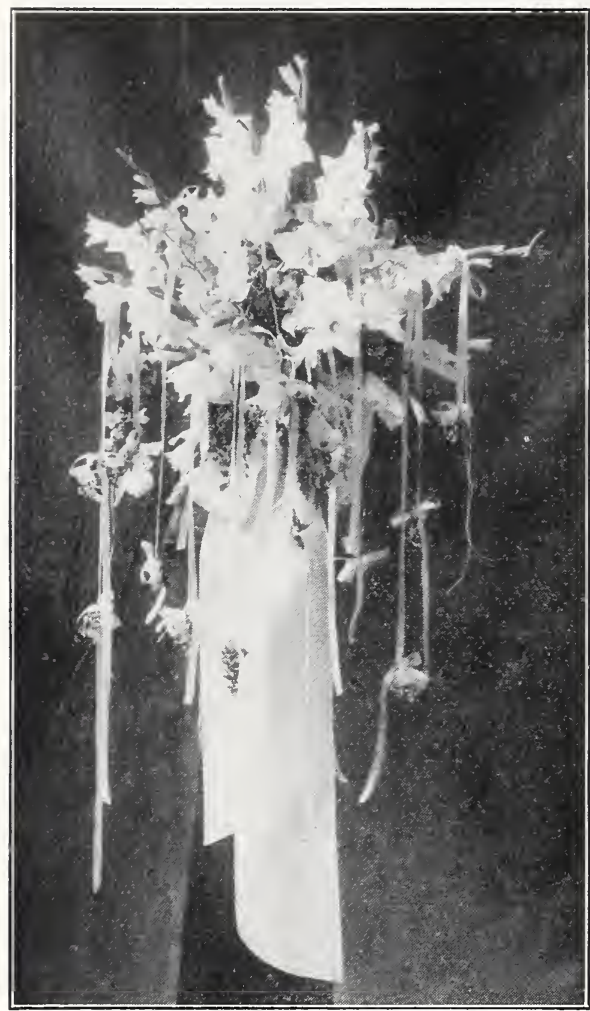

PRETTY BRIDE'S BOUQUET

Here is a lovely floral piece made almost entirely of Gladioli. Short spikes of dainty white primulinus varieties are gathered securely at the base and the blossoms are interspersed with fern. To the white baby ribbon a single floret is tied about four or five inches apart and the large bow is a silk ribbon four inches in width. The effect is most bcautiful.

eties of Gladioli. Is it any wonder why the Gladiolus should be called the "king" of the summer garden?"

Florists too have come to regard the Gladiolus as the all-purpose flower. You will see in the windows of the floral shops, baskets of Gladioli that compel you to stop and admire. You will see bridal wreaths unsurpassed for beauty and made up entirely with Gladioli. For funeral pieces and on frames and forms of every shape and style they produce effects beyond imagination.

Let me suggest what to do if you want the most beautiful bouquets, the most magnificent baskets, the loveliest table decorations, the most charming corsages, and equally important, the most beautiful garden in your neighborhood. Go through my catalog carefully, select col- ors which most appeal to you and make up your lists. You will find four classes to choose from, first the ruffled kinds, varieties for which the name of Kunderd is internationally famous. The first listing will be the new introductions for 1931. If you order from this list you will be first to have these sensational new kinds. Next in the ruffled class you will find such names as Crinkles, Chalice Flower, Dr. Nelson Shook, E. J. Shaylor, Kunderdii Glory, Purple Glory, and others that are well known to every flower lover and varieties which have won premier honors. Then you will find New Plain Petalled Kinds, introductions for 1931, followed by such famous kinds as Mrs. Frank Pendleton, Blue Isle, Cardinal Prince, Dr. J. H. Neeley, Gov. Hanly, Kunderd's Yellow Wonder, and many others. Following the plain petalled kinds are the Primulinus varieties which work so beautifully into more delicate bouquets, table pieces, corsages, etc. Finally are listed the laciniated varieties which I originated and which are becoming very popular. These too, are used where a beautiful delicate effect is desired. Select as many as you can plant, in borders, masses, beds and in among your other flowers, roses, shrubs, etc. Your varieties should be chosen from each of the four classes in order that you may enjoy the Endless Uses of the Gladiolus.

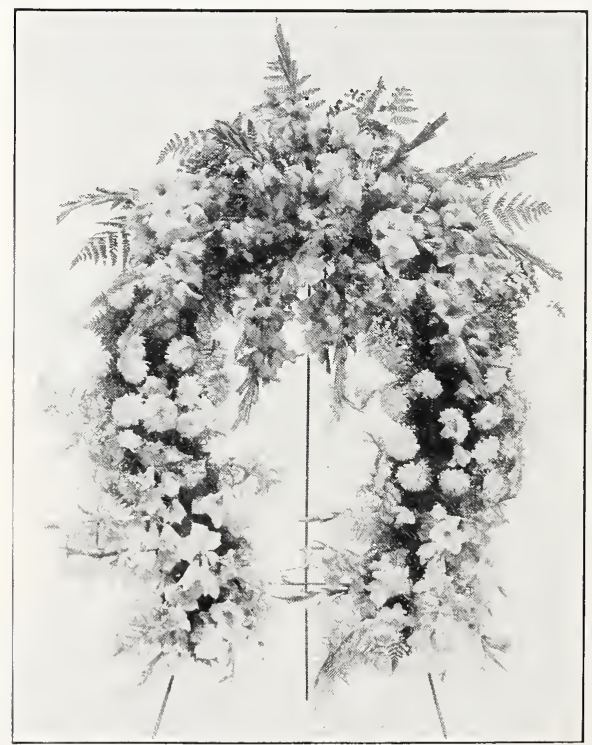

IMPRESSIVE FLORAL EMBLEM

An easily made floral emblem of very attractive design, made of the Gladioli "Uhlan Chief" and "White Butterfly," "Statice" and "Baby's Breath" added matcrially to the effectiveness. 


\section{Sending Gladioli to Your Friends}

I know of no more acceptable or more appreciated gift than flowers, and gladioli, being so beautiful and so easily managed, make ideal flowers to raise in your garden for the purpose of gladdening the hearts of your friends and neighbors.

You know, of course, that most varieties of gladioli grow facing one way on just one side of the spike. There is a decided advantage in this because they can be packed in boxes with little danger of injuring them. The proper way to pack gladioli is to use a strong paper box of adequate size. It should be long enough to allow plenty of room for the spikes. They should not be cramped under any circumstances. Lay a row of gladioli along the bottom of the box with the flowers up, arranging them side by side snugly. The next row should be lower so as not to injure the blossoms on the bottom row and continue in layers until the box is filled. Packing them in this manner makes it possible to send the flowers for reasonably long distances. Before packing the flowers they should be allowed to stand in water for a few hours or until they have absorbed a good supply of water. They should be cut when only one or two flowers are open and do not cut the spikes too deep into the plant.

If you have an ample planting of

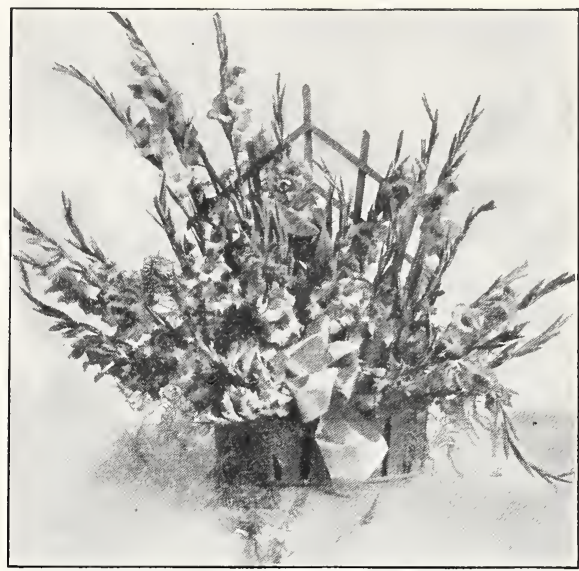

BRIDGE BASKET BOUQUET

Several years ago this beautiful basket was exhibited in the National A. G. S. show and it easily captured first honors. The variety used was Helga and today it is as popular as ever. Golden copper bronze ribbon added a delightful touch to the effect of this attractive display. Try to produce some nice floral pieces from your Gladioli next summer.

gladioli, it is a wonderful thing to present some of the flowers to churches, clubs, hospitals, etc. The illustrations on this page will serve as suggestions on how to make up baskets, bouquets and

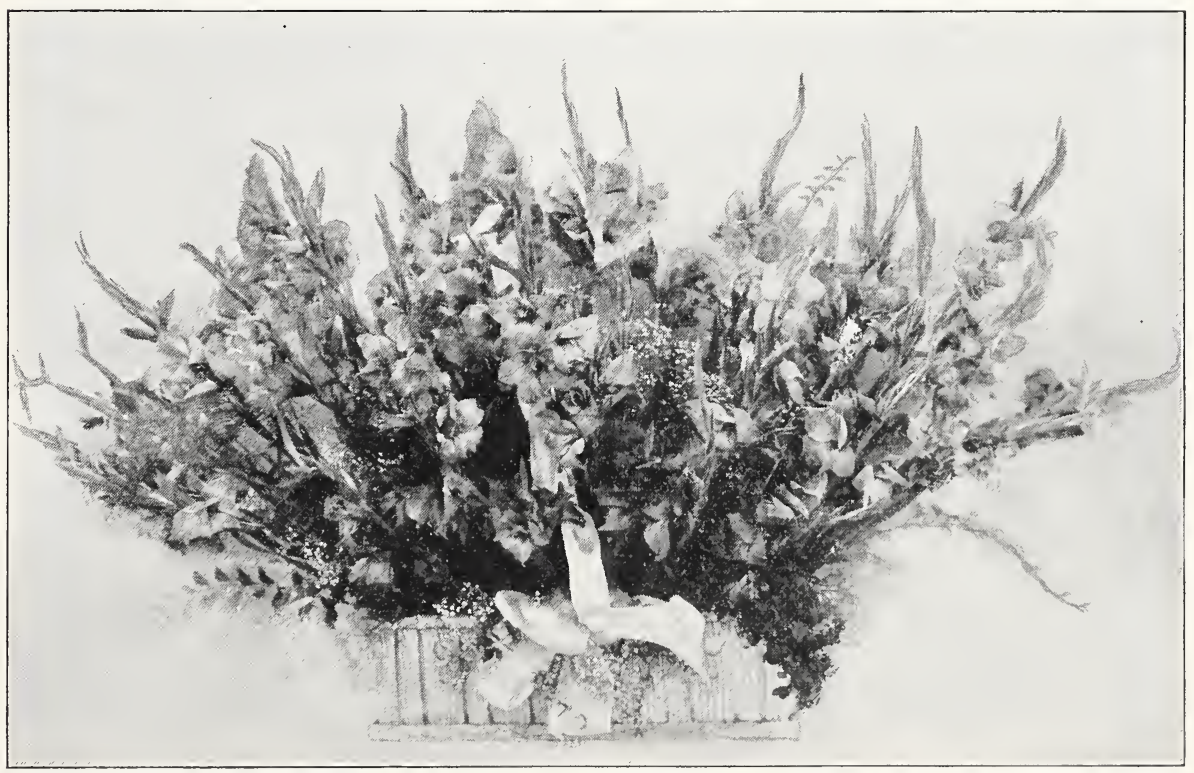

A MASSIVE BASKET DECORATION

"Orange Glow" in effectively arranged basket. A green ribbon added materially to the appearance 


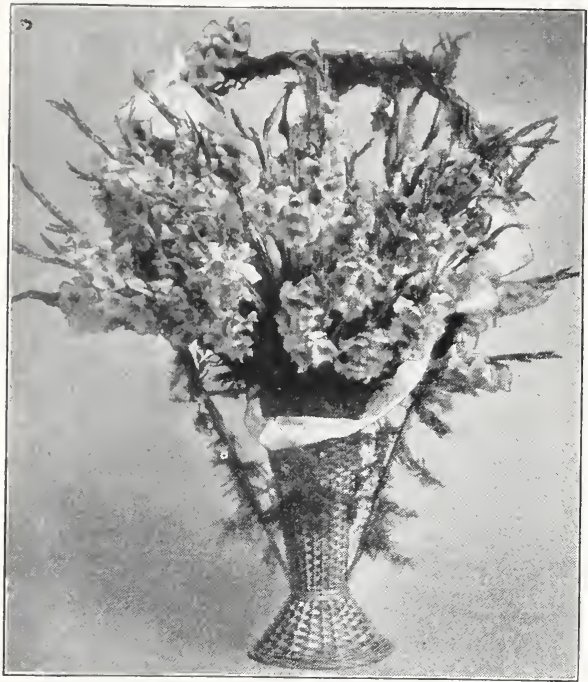

MAGNIFICENT FLOOR BASKET

A huge strikingly beautiful basket consisting of "Kunderd's Yellow Wonder." A light blue ribbon was gracefully interwoven among the flowers.

vases. Men who are proud of their offices will find much delight in a few spikes of gladioli on their desks. Children love to take gladioli to their school rooms, and they should be encouraged in their love for flowers. As the flowers bloom in your garden, you will find an infinite number of new uses for them.

\section{Kunderd Exhibits Are Educational}

At my gladiolus shows each year, I employ expert florists to arrange new floral pieces. In fact, I engage the best talent available to fashion new ideas in baskets, center pieces, funeral pieces, bouquets, etc., in order that my friends may follow the style changes in floral work. In these exhibits more than fifty thousand flowers are used in every possible range of colors. Hundreds of baskets are made up, large ones and small ones, in plain colors and in mixed colors, large flowers and small ones are used with marvelous results. These exhibits are not only of great interest to my friends but give them the advantage of seeing the best. In attendance are men who have been with my organization for many years and who are always glad to answer questions you may wish to ask. They will also explain how certain pieces are made up for best results. We are always glad to welcome you to these exhibits and they are worth going many miles to see.

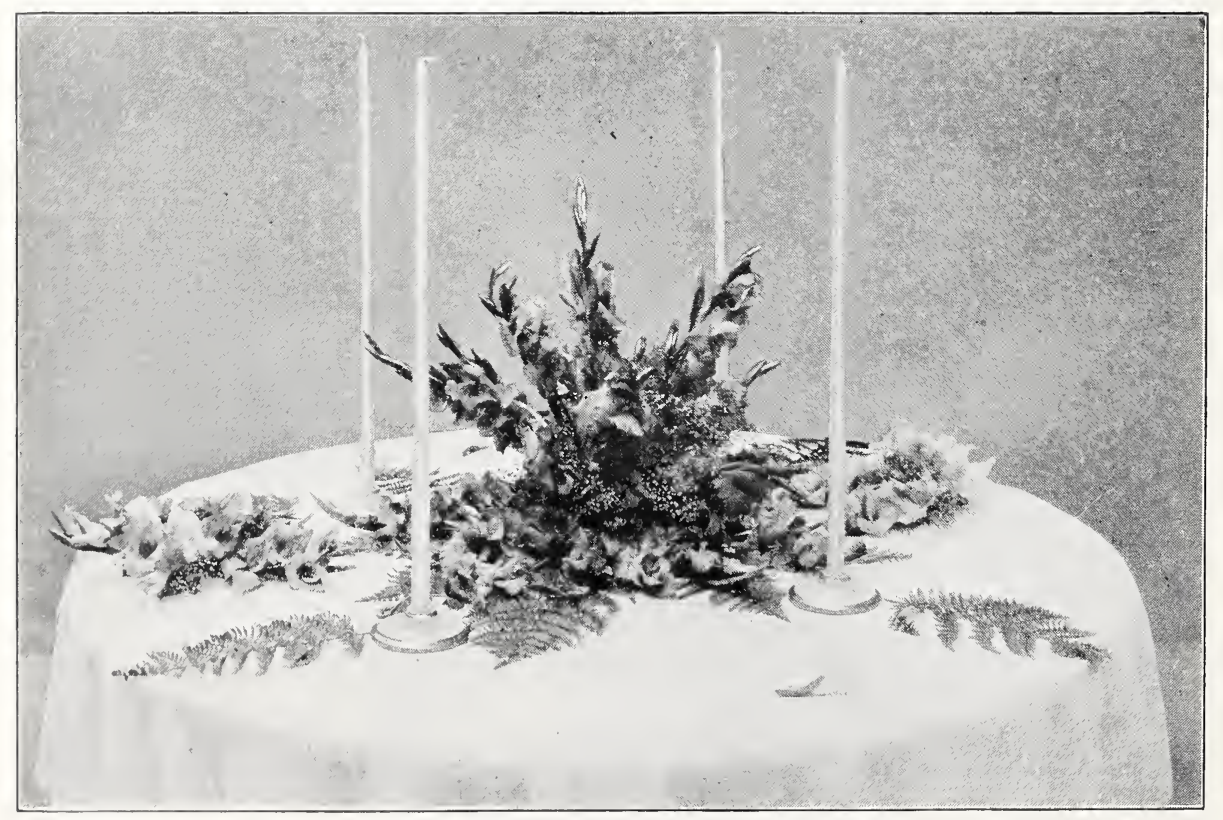

A VERY DELIGHTFUL TABLE DECORATION

Gladioli produce a most unique table decoration, as seen above. The varieties used were "Golden Frills," "Ming Toy" and "Kunderd's Yellow Wonder." The candles were blue, in gold and bronze bases 


\section{World's Recognition of KUNDERD Gladioli}

A VERY amiable gentleman from A Japan called on me one day while I was at work in the field. His interest in gladioli was very keen and I was pleased to learn that he was successfully growing my varieties at his home. One of the questions he asked of me was, "How did you get your start in the flower business?" His question interested me very much for two reasons, first because it indicated his interest in business methods and secondly it implied that my business was large and successful.

It is a very common occurrence to find in my mail letters and orders from France, Germany, Sweden, Denmark, Italy, Holland, England, Norway, Japan, Poland, Russia, and other foreign countries. So widely are my gladioli scattered throughout the world they are constantly in bloom the whole year around. In fact, the sun never sets on Kunderd Gladioli. Pictured on this page is a shipment of more than five hundred varieties of gladioli which were sent to Buenito Mussolini, the Italian Premier.

Kunderd Gladioli have graced the palaces of kings and have adorned the coverts of queens. They are found in the gardens of Monarchs and at the thresholds of peasants. They bring cheer to the living and pay tribute and memories to the dead. Everywhere throughout the civilized world are Kunderd Gladioli. They bring happiness and sunshine to those who are sick and in distress. They bring love and tenderness to those who are humble and without friends and call forth words of admiration from those who enjoy wealth. Kunderd Gladioli are loved by millions, rich and poor alike and the world has paid tribute to my work of plant growing and breeding covering a period of more than fifty years.

Recognition is gained by merit. I can recall many incidents that have compelled world wide attention but they were short lived and the world soon forgot them. I do not consider this recognition for the incident was without merit. Recognition gained upon merit is bound to prevail and it is with considerable yet pardonable pride that I have seen my gladioli recognized internationally for more than a period of twenty-five years. Furthermore, I feel sure that I will not live to see the day when my gladioli will enjoy less popularity than at present.

Recognition was not easily gained. I struggled for more than twenty-five years before I developed and introduced the ruffled gladiolus. Upon this achievement I gained international recognition. My first efforts were as strenuous as any during my lifetime for I was then without funds or encouragement. My method of sales and distribution was from door to door. My trial beds were a few choice varieties, the best known at that time. My tools were books and fervently did I use them. Fortunately I was growing my pets in ground most perfectly adapted for gladioli. This happened more by coincident than by good judgment. Obviously I am still growing my gladioli in ground similar to that in which my first experimentation took place. This is not by coincidence.

Because of the present system of news distribution we hear more about Kunderd Gladioli in this country than we do from foreign countries. Consequently I will relate by virtue of recognition some of the success others have attained with my introductions.

I will take for example the well-known variety, Mrs. Frank Pendleton, which was introduced in the year of 1910. This flower is a bright rose-pink on a pure white ground and with a giant blotch of richest carmine-red on the lower petals. It is a large flower of the plain petalled

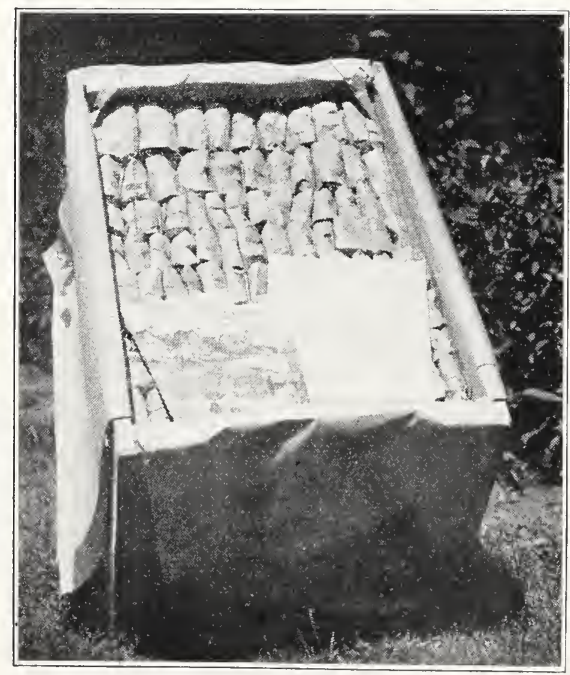

Shipment of Bulbs to Buenito Mussolini, Italy, containing Five Hundred Different Varieties 


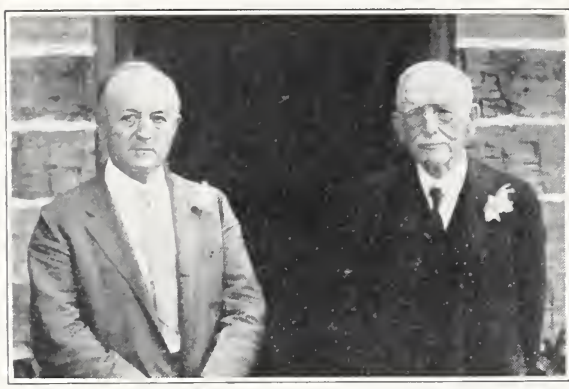

World's Foremost Rose Grower Meets World's Foremost Gladiolus Grower on the Occasion of Mr. Kunderd's Golden Anniversary

type. It was awarded highest honors by the American Gladiolus Society and the Mass. Horticultural Society. More than this, however, it has become the leading variety among the florist's trade. Millions of dollars have been profited by growers for this single Kunderd origination. Furthermore, "Pendleton" is equally popular in other countries. "Scarlet
Princeps" (Virginia) is another variety which has grown to be a great favorite throughout the world and its popularity is closely followed by such well-known kinds as "Purple Glory," an outstanding ruffled type, Crinkles, ruffled as the name implies, Marie Kunderd, the most beautitul of all whites. Dr. Nelson Shook, a mammoth ruffled red, sales of which run into many thousands of dollars each year. I could go on down through my list of popular favorites, naming you varieties which have become internationally famous.

In various communities where the love of fine flowers is most pronounced and where there is a constant effort to better the types, colors, etc., there are flower shows which command no little interest on the part of the public. There are state organizations sponsoring such events and there is the National organization which each year puts on a show of international competition. In all of these exhibits it is important to note that Kunderd originations are the most prominent among the list of winners.

\section{Why Kunderd Gladioli Represent the World's Greatest Value}

WHEN you buy your Gladioli from Kunderd you are getting them directly from the originator and you are therefore, more certain of receiving true varieties under their proper names. You are sure, too, of getting the finest varieties, kinds that have become universal favorites. You get the most exquisite colors that have ever been produced in these magnificent flowers. You get a variety of types and the greatest assortment of colors and shades. You get a quality of bulbs which only Kunderd produces. You get flowers which are superbly beautiful and you get value unequalled.

In previous articles in this book I explained how carefully I grow my stock in order that you may enjoy the very best possible blooms in your own garden. My files are filled with letters from customers who report one hundred per cent bloom from the bulbs I send them. In fact this is the usual result. Such a high percentage of bloom can only be possible from bulbs that have been properly grown and cured. My customers actually enjoy growing my flowers as much as they do picking the magnificent blooms. I also receive letters from small children telling me what good success they have had with the bulbs I sent them. When you receive Kunderd bulbs they are as nearly perfect as it is humanly possible to make them and that is why they bloom so readily and so perfectly.

Plan your garden this spring with a sufficient number of choice Kunderd Gladioli to make it an object of outstanding beauty. Enjoy the unusual value I offer you, the marvelous flowers which have made Kunderd originations world famous. Plan your garden to have Kunderd Gladioli in bloom all summer long. The joy, the happiness and lasting satisfaction you will receive from gladioli cannot be measured in terms of dollars and cents. Nothing can equal Gladioli for the home, they are the outstanding flowers for cutting and arranging in baskets, bowls and vases.

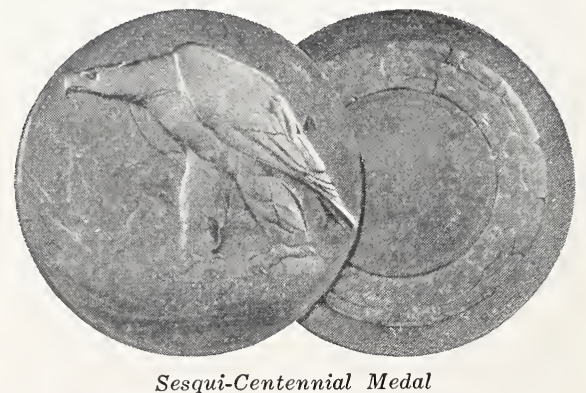

Sesqui-Centennial Medal 


\section{Why I List Only Kunderd Originations}

$A^{S}$ you read through my catalog you $\mathrm{A}$ will note that every variety listed is my own origination. This is unusual, of course, yet it has a particular significance. If you are a student of flowers you will be able to detect certain characteristics of the originator. I have had many people tell me that they are able to pick my varieties almost on sight.

In the past twenty years or more I have had unlimited resources with which to carry on my work of hybridizing. My trial grounds are the largest in the world and my experimentations are accomplished on a tremendous scale. Each year I discard more things than all originators combined, produce. From the thousands of colors and color combinations, I am able to select the varieties that have won for me the universal recognition I now enjoy.

The highest award at the National shows is ample proof of my ability to produce the finest varieties of the gladioli. In the best gardens in the world where cost is never considered, one can find Kunderd gladiolus varieties predominating. Those listed in my catalog are the finest. They are offered to you at prices consistent with quality and quantity. Many of my most unusual kinds are priced very low. This is due to the fact that I am able to produce them in sufficient number to warrant a lower price. Whenever you find a variety in my catalog at a high price you may rest assured it is worth that price, because it is new, rare and scarce.

I have a certain method of producing bulbs. Fifty years have taught me how to do this in order that each and every customer can have as fine flowers as I

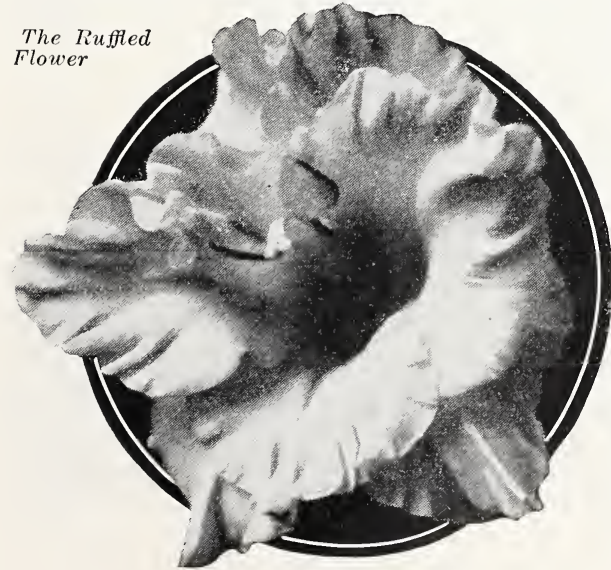

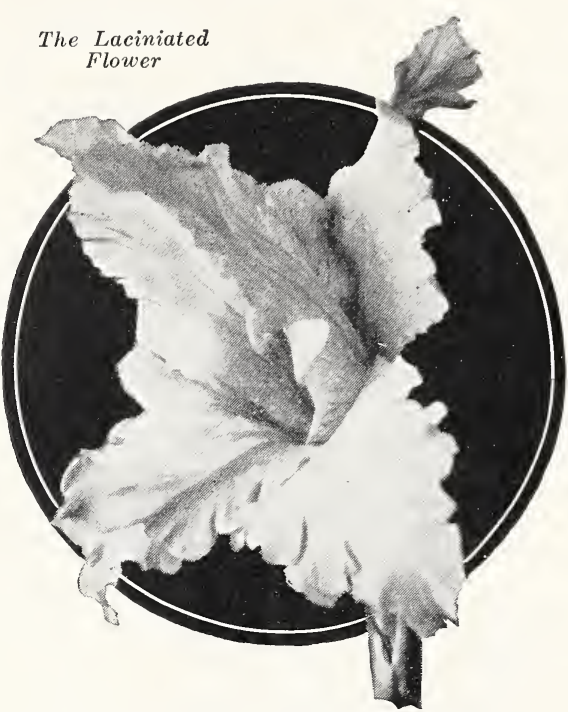

am able to grow right here under my own care. Thousands of people throughout the world, who are able to supply water, artifically, produce better flowers of Kunderd varieties than I. This fact gives me my greatest satisfaction. If you could read the many letters that come to me each day from the most enthusiastic customers you would realize why their comments give me my greatest enjoyment. The bulbs you receive from me are fully guaranteed. They are grown and cared for under my personal supervision and they are certain to reach you in excellent condition. To be absolutely sure of the finest flowers, order direct from my catalog. Small orders get the same attention as large ones. I know of no investment in the world, large or small, that could give you as much enjoyment as a garden full of Kunderd gladioli.

H. W. Elverson, Pennsylvania. "Though I have been but a very small customer, I am overflowing with appreciation and praise of your matchless Gladioli. Most of the bulbs I purchased from you during the last three seasons were in mixture, yet not a few I have been able to identify from your catalog. While it is gratifying to be able to point out, by name, these wonderful flowers, yet after all, there is in planting mixtures, something we do not get from planting named varieties. That something is the joy of anticipation realized when the flower opens. We plant the bulbs and watch with nerves high pitched the blooming-and then, what wonders! My garden space is small, could find room for only 125 bulbs this season but look forward to planting 300 or more next spring and the increase will be of your growing." 
I $\mathrm{N}$ addition to my greatly reduced 1 prices this year I am offering exceedingly liberal discounts in actual cash in consideration of early orders. Because I can handle your order so much more conveniently before the last minute rush I gladly make this liberal discount in cash.

At these price reductions it is now possible for everyone to enjoy a garden full of genuine Kunderd Gladioli. You will no longer have to be satisfied with substitutes for Kunderd Gladioli. These discounts, shown below, apply to individual orders as they are sent to me. If you send me several orders within the time limit, to receive these benefits, each order must be figured separately on the basis of my offer. Orders coming at different times cannot be combined to receive the greater discount. The prices quoted in this book will remain fixed, and there will be no special "late season" prices at the end of the season. If you should receive a second copy of this book or are not interested in the one I am sending you, I would be grateful if you will kindly hand it to a friend who is interested in the culture of beautiful flowers.

Kunderd Gladioli are the greatest value by far and now you can buy them at greatly reduced prices plus extra discounts, for simply sending in your order early.

\section{DISCOUNTS BELOW ALLOWED ON CASH ORDERS TO, AND INCLUDING FEBRUARY 20th, 1931}

\section{BEFORE ORDERING PLEASE READ NOTES ON NEXT PAGE}

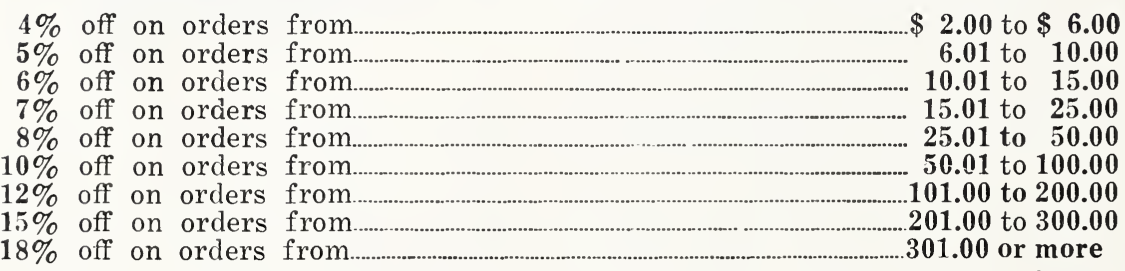

Orders of $\$ 2.00$ and under are net, no cash discount will be allowed but if sent before February 20th, 1931, I will include one extra bulb of a choice named variety complimentary.

\section{SPECIAL NOTICE}

Above Discounts and Extras Apply Only on Retail Gladiolus Orders.

Orders for Seeds, Iris, Peonies, etc., Cannot be Included in These Discounts.

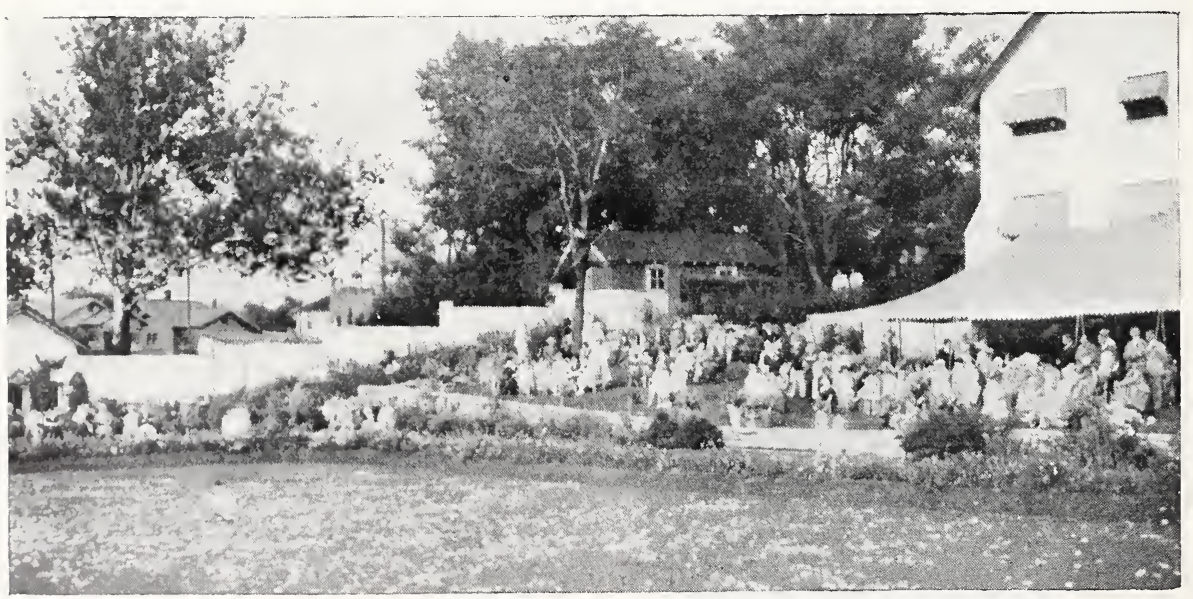

Garden Party at the Home of Otto and Mary Louise Carmichael, Muncie, Indiana, at which Mr. Kunderd Was Feted on the Occasion of His Golden Anniversary 


\section{Please Read Carefully Before Ordering}

SEND ORDERS EARIY to be more certain of getting all varieties wanted. Late orders coming during my planting season may be delayed a few days. Please use the order blank sent with this catalog.

SAFE ARRIVAL OF BULBS IS GUARANTEED to any point within the United States and Canada. I care for the bulbs during the winter months and ship them as soon after February 15 th as the weather permits, but will make earlier shipment if you desire, sending the bulbs by express to insure against freezing. Such orders are sent express collect.

TERMS. Remittances must accompany all orders. Send bank draft, express or postal money order, or if more convenient for you I will accept your personal check. Unused U. S. stamps will be accepted in payment of orders amounting to less than $\$ 1.00$.

ALL GOODS ARE SEN'T TO YOU TRANSPOR'TATION PREPAID at prices quoted in this book unless shipment is requested before regular shipping season, which starts about February 15th.

CI.AIMS FOR SHOR'TAGE must be made immediately upon receipt of goods.

REFERENCES. To those who may not know me, I refer by special permission to the following Goshen banks: The City National Bank, and the Salem Bank and Trust Co. Also R. G. Dun \& Co., and Bradstreet's Commercial Reports.

FOREIGN SHIPMEN'TS. I cannot guarantee safe arrival to foreign countries (except Canada) due to the delay and risk in transit which is entirely beyond my control. Special effort will be made to ship in proper season, to send only first-class, well-cured bulbs, also to pack well, but I cannot replace any stock arriving in unsatisfactory condition. From reports received from foreign customers, I find that over $95 \%$ of shipments arrive safely and in good condition. I can only accept Canadian and other foreign orders in American exchange. Please remit by international draft or money order either on New York or Chicago, in full value of American money. Canadian customers, be sure to give number of your import permit with each order and send me the shipping tag provided by your government. Canadian orders will be shipped with certificate of inspection from our State Entomologist as required by the Canadian Insect Pest Act.

SUIBSTITUTION. Many years of experience have taught me the value of substitution, providing something similar or of greater value can be supplied. I find 99 out of 100 customers prefer this method, but if you do not wish any substitution please say so when ordering and any difference will be cheerfully adjusted.

SUBS'TITUTION IN COLLEC'TIONS. I reserve the right to substitute when out of a variety offered in any of the collections. The stocks are not of the same size and late in the season some may be entirely exhausted when your order arrives. Collections can be furnished only as described, at prices given. No alterations can be made in the collections described and offered in this book.

WHERE OFFERED BY THE DOZEN, six may be ordered at half the dozen price. Less than six at single rate. Where offered by the hundred, fifty will be supplied at the hundred rate. Less than fifty at single or dozen rate. Exception-twenty-five may be ordered at the hundred rate in my four mixtures; 250 at the 1,000 rate.

SPECIAL COLLEC'TIONS of named varieties (labeled) will be made up for any of my customers who may wish my aid in deciding what to plant. Nothing can make a finer present to a friend than a collection of choice Gladioli. Please state choice of colors, varieties you have grown and amounts you wish to buy.

DO NO'T HESI'TA'TE 'TO SEND SMALL ORDERS, even if for a single bulb. I want to help the smallest grower or beginner.

NO MIX'TURE OF ALL RUFFLED VARIE'TIES is offered in this book.

WHEN FULL REMI'TANCE DOES NO'T ACCOMPANY AN ORDER it will be sent C. O. D. for the balance. However, do not send balance later because the orders cannot be easily located after they are sent to the shipping department. Oftentimes even though the balance is sent the order passes through the shipping and mailing departments without being noticed and comes to you C. O. D. Then it is necessary to send refund.

DISCOUN'TS AND EX'TRAS IN THIS CA'TALOG apply only to strictly retail Gladiolus orders and are figured on each individual order. That is, it is not possible to send orders at various times and then have the discount and extras figured on the combined orders.

WHEN MY CUSTOMERS DO NO'T TAKE THE CASH DISCOUN'T or select other gladiolus to the amount equivalent to the discount, my order department will send additional named varieties to balance this. 


\title{
Introductions for 1931
}

\author{
The finest in the land, may well describe these new beauties. They are \\ the result of more than fifty years of constant study and application. \\ They are premier from the standpoint of beauty and perfection. These \\ new ruffled originations for 1931 will be available this year for the \\ first time. Plant them in your garden and enjoy the last word in \\ floral beauty.
}

Achievement (1931)-Fine height and vigorous, strong plant with giant widely expanded flowers. Five or more open at a time, intensely ruffled. Color of rich deep canary yellow with very large beautiful red blotches on lower petals. A magnificent and showy variety to be classed among the very best. Each, $\$ 10.00$. Doz., $\$ 100.00$.

Cyprian (1931)-Good height plant. Very large intensely ruffled flowers of richest creamy yellow. Lower petals delicate canary yellow with a fine pink feather half way down the center. One of the richest showiest and very finest. Each, \$3.00. Doz., \$30.00.

Florence Winter (1931)-Large, tall and stately plant and very large flowers. Beautiful pure white, daintily blushed, a soft pink on outer edges of all six petals. Lower petals are deeper blushed pink on inner portion with soft creamy blush or flesh color on outer portion, ends of lower petals of soft white daintily blushed. A very extra and showy new ruffled variety of great beauty and quality. Extra fine. Each, \$3.00. Doz., \$30.00.

Joanna Hill (1931)—Extra strong, tall vigorous plant and large flowers with plenty open at a time. Color a most pleasing deep peach blossom pink. Much deeper large pink inner throat. A fine narrow central creamy white bar or feather extends down the center of each petal into the base of the throat, beautifully feathered white on either side near the base of the petals. A narrow white line borders all six petals and all petals are waved with broad waves, not ruffles, giving this flower a very refined and elegant form, equaled by few. An extra show and garden variety. Fine in any light, or out of doors. Each, \$3.00. Doz., \$30.00.

Julius Rosenwald (1931) - Tall stately plant. Large flowers of most beautiful orange salmon color. Large central upper petal very upright giving the flowers a striking appearance. Lower petals have large blotches of a very showy blush coior. Easily among the most attractive and beautiful of all Gladioli. Each, \$2.00. Doz., \$20.00.

Lavender Frills (1931)-Fine good height plant and good size flower, very ruffled and widely open. Color richest pure deep lavender with large pure white throat. White median lines on all petals. A blending of white and richest deep lavender hard to describe and of most pleasing effect. A color much needed and a very fine lavender variety. Each, $\$ 2.00$. Doz., \$20.00.

Mikail (1931) - A tall stately plant and very large flower of remarkable and extraordinary color, as beautiful as any Gloxinia and as rich in color. Ground color a beautiful purple or violet rose pink, flaked a fine rose red. Entire inner throat covered with a wonderful pansy or Gloxinia-like blotch of intense velvety dark red, again bordered and mottled. A delicate creamy border. In every way a remarkable striking and showy flower. Each, $\$ \mathbf{5 . 0 0}$. Doz., $\$ 50.00$.

Mrs. Dr. Bevan (1931)-Very tall and stately plant with five or more very large flowers open at a time. Flowers widely expanded and upper central petal placed very upright giving the individual blossom a very distinct and striking appearance. Color of upper petals and ends of lower petals of purest white with faintest tint of cream. Lower petals are almost covered with wonderful blotches of a deep golden cream with only a very narrow central thread line of softest rose pink half the length of the petals. A very refined and elegant flower. One of the finest I have ever introduced, a very magnificent and beautifully ruffied variety. Each, $\$ 3.00$. Doz., $\$ 30.00$.

Mrs. Laurance Armour (1931)-Tall strong plant, large flowers widely expanded. Ground color white with a fine soft rose pink over upper petals. Lower petals somewhat lighter and have blotches almost as fine as Pendleton. A much improved Bothin, finer 
colors and more ruffled. Very choice and fine. Each, $\$ 2.00$. Doz., $\$ 20.00$.

Otto Carmichael (1931) - Fine, tall stately plant with many large and very showy flowers open at a time. Color intense deep yellow of a rich golden tinge, intensely ruffled. Outer border of the petals are richly blushed or tinted a beautiful golden tone still deeper with soft pink flush. Lower petals have soft rose pink narrow feathered central lines. A truly magnificent golden yellow named for a distinguished and famous Hoosier. Each, $\$ 10.00$. Doz., $\$ 100.00$.

Southern Beauty (1931)-Tall fine plant, good size blooms with plenty open at a time. Color intense salmon rose. A little lighter in upper portion. Lower throat beautifully penciled deeper rose red and delicately subdued white, with still deeper central bars of rose red. Lightly red on all petals. A beautiful and distinct variety. Each, \$1.00. Doz., 10.00 .

Southland Queen (1931)-Fine height plant, good sized flower. Color of richest deep tyrian red or American Beauty rose, faintly flaked deeper on outer edges of petals. Upper portion of throat blushed lighter. Lower portion of throat beautifully penciled with a soft old gold on deeply colored American Beauty rose. A very distinct showy and beautiful color combination. A fine new ruffled variety. Each, $\$ 2.00$. Doz., \$20.00.

White Lavender (1931) - Fine height plant with good sized flowers intensely ruffled. Color a pure self colored white, delicately lavender blushed over entire flower. Upper central petal large and upright. An extremely distinct and elegant variety destined to become very popular. Each, \$3.00. Doz., \$30.00.

\section{Collection Offers \\ 1931 RUFFLED INTRODUCTIONS}

These Collections Are All Sent with Each Variety Properly Labeled

Collection No. $1-$ All varieties valued up to and including $\$ 2.00$, 5 in all (value $\$ 9.00$ ) for........... \$8.10

Collection No. 2-All varieties valued at $\$ 3.00,5$ in all (value $\$ 15.00$ ) for................. \$13.50

Collection No. 3-All varieties valued up to and including $\$ 3.00$, 10 in all (value $\$ 24.00$ ) for ......... \$20.40

Collection No. 4-All varieties valued up to and including $\$ 5.00$, 11 in all (value $\$ 29.00$ ) for......... \$24.65

Collection No. 5-Entire collection, one each of the 13 varieties listed (value $\$ 49.00$ ) for.......... \$41.65

Varieties Included in These Collections are Listed on Pages 14 and 15

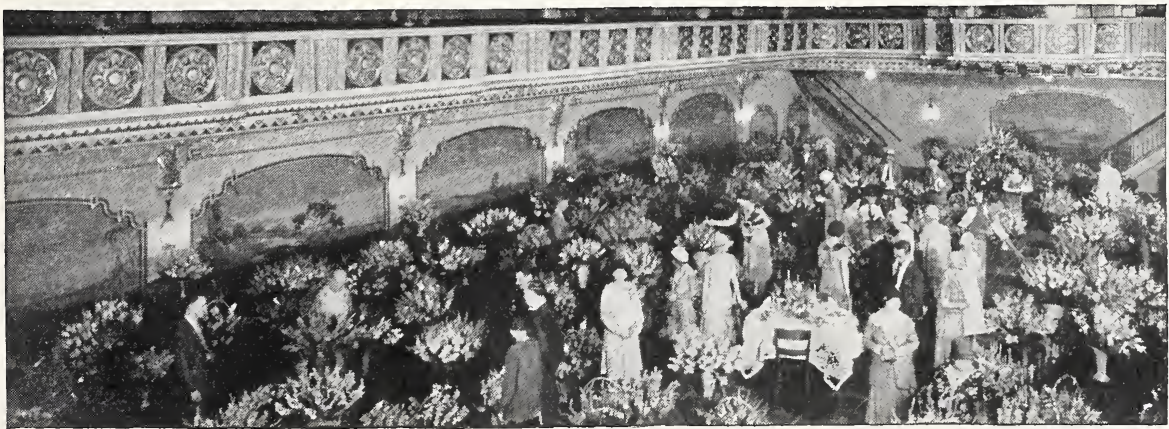

The Largest One-Man Gladiolus Show Ever Held in This Country-All Kunderd Varieties. The Above Is a Partial View of the 1930 Gladiolus Show in Chicago

A. E. Kunderd, Goshen, Indiana 
Last year I made the prediction that my 1930 introducitons would become extremely populat. That prediction certainly has come true. Wherever they have been seen they have been praised. Those who purchased them were pleasantly surprised at blooming time when these aristocrats of the flowering kingdom revealed their beauty. The prices of the varieties in this list of gladioli have been materially reduced and now more of my flower friends can en joy their rare and luxuriant beauty.

Brown Lily (1930. 64 days.)-Tall plant with large flowers, petals, curled, twisted and pointed in finest lily fashion. Prettily feathered red throat blotches on a beautiful soft creamy ground. An unusual and attractive garden variety. Each, \$1.00. Doz., $\$ 10.00$.

Canary Feather (1930. 80 days.)-Nice height, graceful slender plant with large nicely shaped and perfectly placed flowers. Color of upper petals and ends of lower petals a delicate canary yellow. Lower petals much deeper rich canary or medium daffodil yellow, slightly penciled soft pink towards the base of the throat. A very elegant and refined yellow. Each, 75c. Doz., \$7.50.

Classic (1930. 87 days.)-Medium height plant with five or more large flowers, beautifully and elegantly placed. Color daintiest deep salmon rose with softest clear creamy yellow throat, as beautifully blended as in any rose and as elegant and dainty a shading as in any rose. Very fine in outdoor light and extremely beautiful in artificial light. Each, \$2.00. Doz., \$20.00.

Country Gentleman (1930. 75 days.)Extra tall, graceful plant. Very large heavily ruffled flowers, beautifully formed. Color cleanest, clear canary yellow, deeper yellow on lower petals. Lower petals have long central bars which are divided into five beautifully alternating red and yellow thread lines giving the flowers a very fine appearance. An extra fine yellow. Each, $\$ 2.00$. Doz., $\$ 20.00$.

E. C. Vick (1930. 75 days.)-Fine height and showy plant. Flower, large, elegantly ruffled and six to eight open at a time. Color a deep Tyrian rose red, or medium dark rose red. A neat feathered darker red on lower throat petals. An extra showy and fine shade of rose red. Each, \$2.00. Doz., \$20.00.

Evangeline Booth (1930. 74 days.)Very tall, straight fine plant and large flower. Color deep pure rose pink with large feathery rose red throat blotches. Medium ruffled. Another variety similar to E. J. Shaylor, but tall and a more showy plant. An excellent variety. Each, $\$ 1.00$. Doz., $\$ 10.00$. Good Morning (1930. 71 days.)-Graceful, fair height plant. Flowers of good size, gracefully placed and five or more open at a time. Color, deepest pure deep glowing salmon red. Large creamy-white throat extending well out over the petals. These white throat blotches again have blotches which are very beautifully stippled of finest red. Medium ruffled opening buds reminds one of fine opening rose buds. An exceptionally richly colored and unusually distinct and beautiful variety. Each, $\$ 1.00$. Doz., $\$ 10.00$.

Meadow Lark (1930. 77 days.)-Tall, stately plant with large widely expanded flowers. Petals long, pointed beautifully curved like a fine lily. Color, dark velvety orange red. Throat is beautifully barred with rich, deep and pencil lines on a fine shade of yellow. In every way a distinct and showy flower. Each, 75c. Doz., \$7.50. Morning Sunshine (1930. 83 days.)Tall, stately plant with five or more showy flowers open at a time. Color, deep salmon pink, deeper towards outer edges. Throat a delicate creamy pink on a lighter ground. A refined distinct and beautiful flower. Each, $\$ 1.00$. Doz., $\$ 10.00$.

Old Rose (1930. 81 days.)-Tall, slender and graceful plant. Flowers of medium size, gracefully formed, very ruffled, recurved and twisted or curled petals like a lily. Color, a beautiful shade of old rose deepening towards the outer ends of all six petals. Lower petals have charming blotches beautifully stippled and feathered a delicate creamy white with the old rose color of the main flower. A narrow median line of the same creamy color extends from near the base of the throat, outwardly to near the ends of the lower petals. A charming flower, neat, pretty and graceful. Each, 75c. Doz., \$7.50. Ophelia (1930. 75 days.)-Tall, stately plant with massive flowers. Petals extra wide and of pure deep rose pink, lighter in upper throat, but all six are much deeper rose towards outer edges. (Continued on Page 19) 


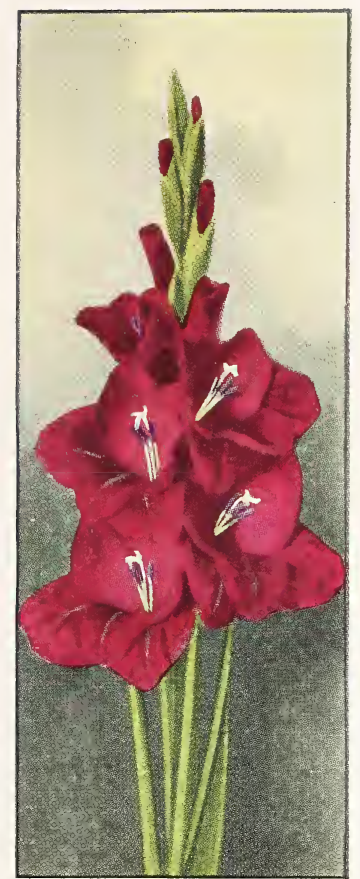

Mrs. Artbur Meeker

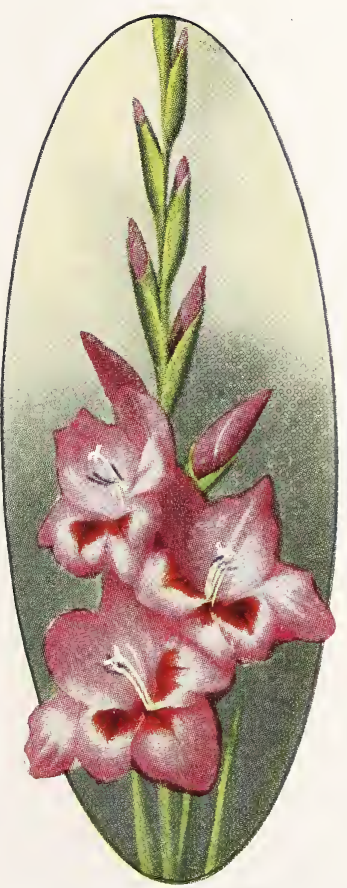

Mrs. Frank Pendleton
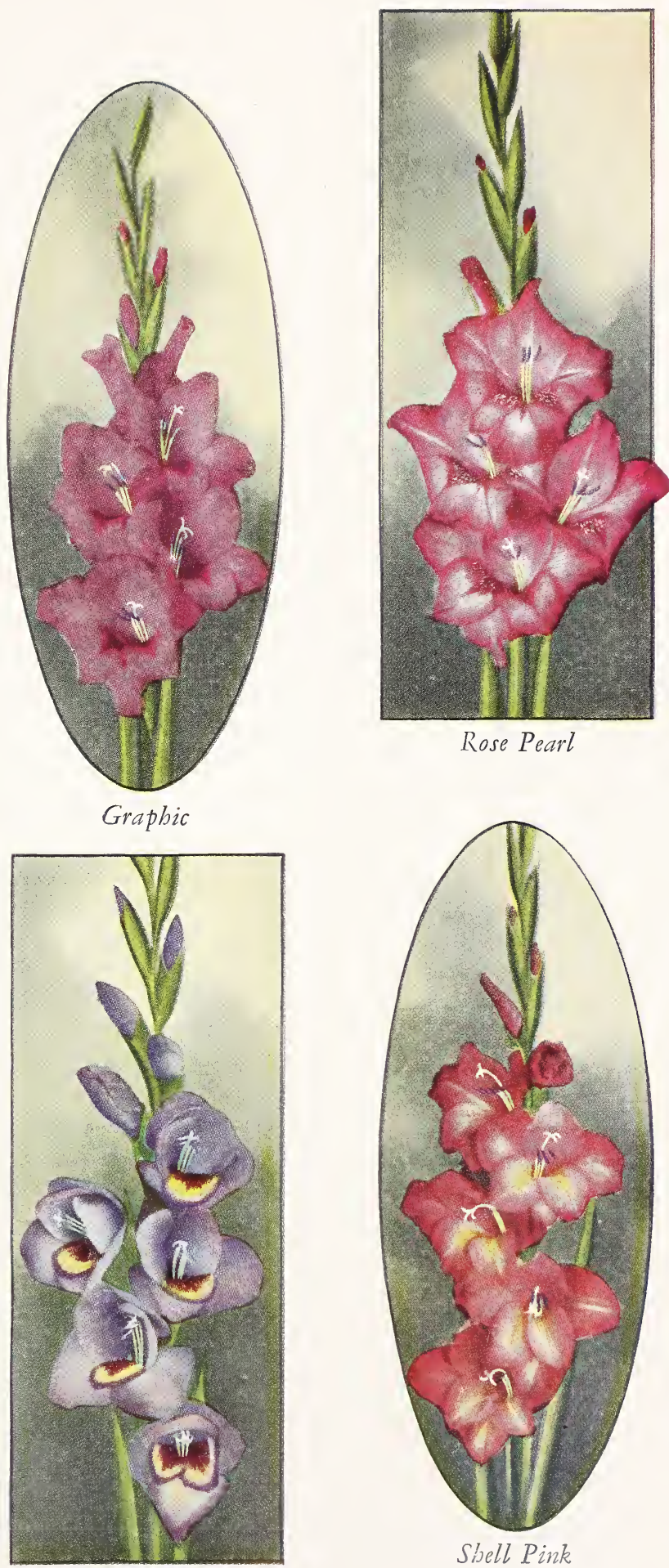

Blue Isle

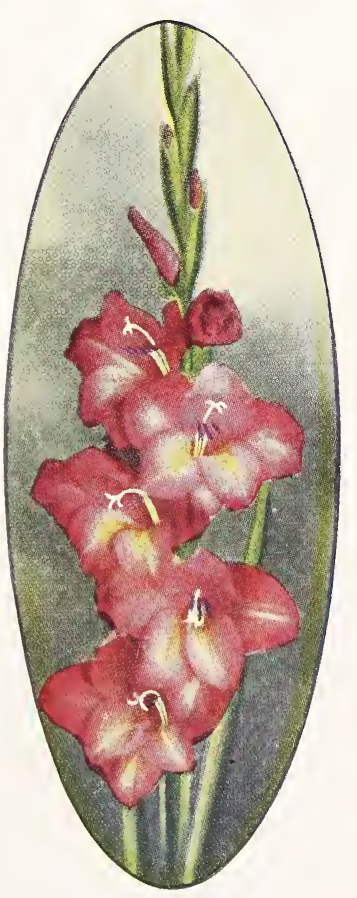

Sbell Pink

For Descriptions of Color Illustrations Refer to Index 


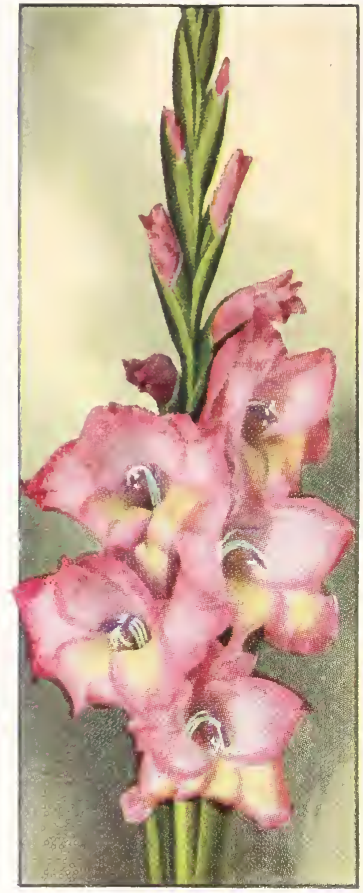

Pauline Kunderd

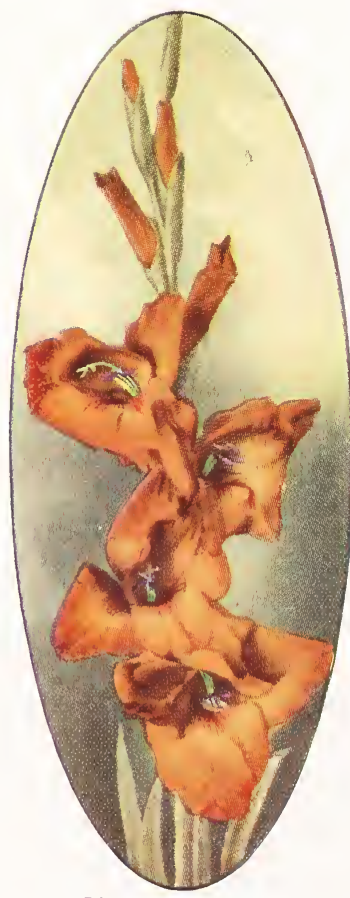

King of Oranges
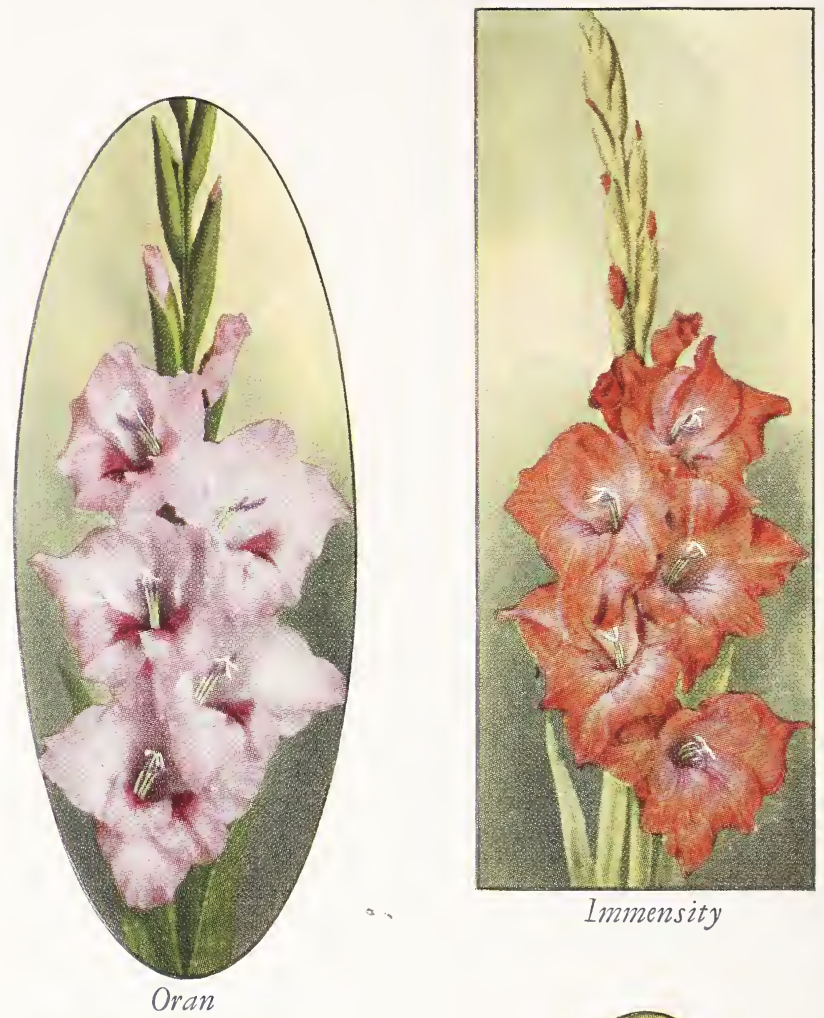

Immensity

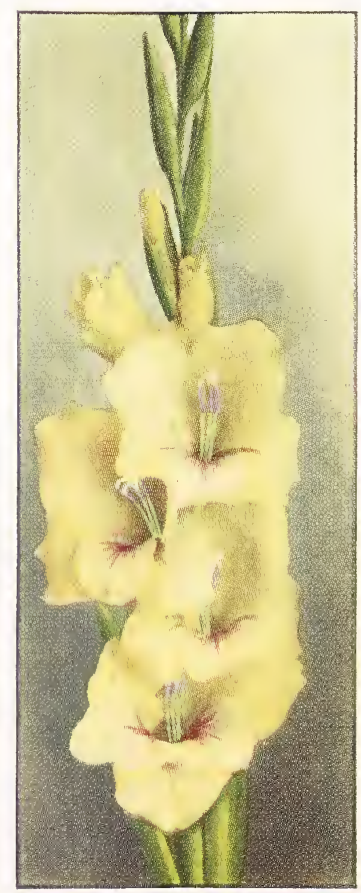

Giant Fawn

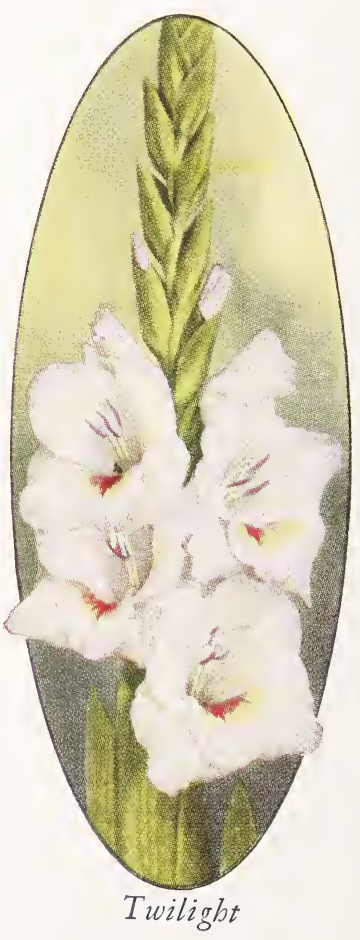

$*$ For Descriptions of Color Illustrations Refer to Index 
(Continued from Page 17)

Lower portion of flower has a wide feathered bar of deep velvety rose red flamed bright red at either side. Opening buds as beautiful as opening rose buds. An extra fine and showy variety and a splendid florist flower. Each, $\$ 2.00$. Doz., $\$ 20.00$.

Orange Feather (1930. 84 days.)-Good height plant and good sized butterfly shaped flowers, strongly ruffled. Color, light orange yellow, flaked beautifully a deep orange, giving the flower much the appearance of the beautiful "Alice Tiplady," only a little lighter in color. A pleasing and very attractive new ruffled variety. Each, \$1.00. Doz., $\$ 10.00$.

Orange Fires (1930. 79 days.)-Medium height and fine plant, with large massive and beautifully ruffled flowers. Color, dark vermilion red. Large throat blotches of deep purplish red with white central lines extending well towards the ends of the petals, giving a very striking and showy effect. A distinct addition to the ruffled list of Gladioli. Each, \$2.00. Doz., \$20.00.

Orange Lily (1930. 65 days.)-Good height plant with giant massive flowers, beautifully ruffled. Upper petals a fine orange color. Lower petals of purest soft chrome yellow, covering entire petals, excepting edges and tips of lower portions. A very magnificent and grand variety. Exceedingly striking and showy. Each, \$3.00. Doz., $\$ 30.00$.

Orchid Butterfly (1930. 62 days.)-Tall and stately plant with very large widely expanded flowers of deepest salmon flesh color. Ends of lower petals of same color as upper petals. Throat elegantly stippled a soft dark red with most of lower petals a very beautiful shade of a delicate straw or creamy yellow. A very orchid or butterfly like flower suggestive of its name. Tall and majestic. Each, $\$ 2.00$. Doz., $\$ 20.00$.

Pink Feather (1930. 79 days.)-Good height plant and a good sized flower on a strong vigorous stem. Six or more flowers open at a time, all facing perfectly. Color soft rose pink on a white ground, beautifully flaked a deep rose pink. Most of lower petals covered with a very beautiful rose red blotch bordered a delicate creamy yellow. An extra fine ruffled variety. Each, \$1.00. Doz., \$10.00.

Pink Pencil (1930. 90 days.)-Medium height plant with five and more large flowers open at a time. Color a fine tone of flesh softly flaked or delicately blushed a little deeper towards the outer edges of the petals. Throat finely

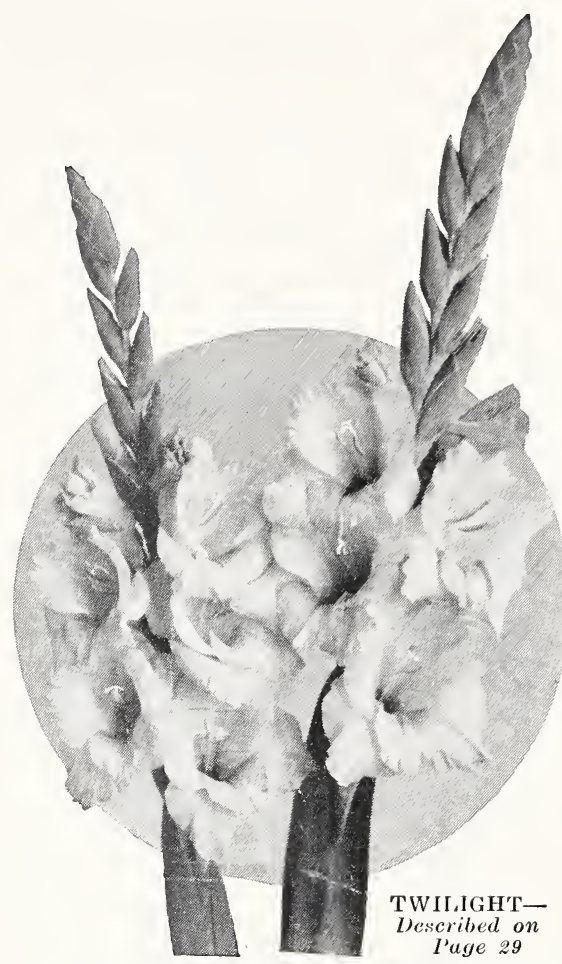

feathered with lightly penciled white and pink penciled thread lines in beautiful effect. A refined and elegant light tinted variety. Each, 75c. Doz., \$7.50. Rosemary Hayes (1930. 77 days.) - Tall fine plant with six or more large flowers open at a time. Color bright rich rose, lighter in upper portion with nearly white, subdued lines on center bars of upper petals. Lower petals have narrow dark red bars in midrib with finely feathered alternate red and white thread lines on either side. Kunderdii ruffled type, lightly ruffled. A fine showy plant and flower. Beautiful. Each, \$1.00. Doz., \$10.00.

Salmon Ruffles (1930. 83 days.)-Nice height plant and fine spike. Color a bright deep salmon rose red. Very pure and even color all over with a beautifully formed humming bird shape blotch of deep red on lower petals. A choice and beautiful Gladiolus. Each, 75c. Doz., \$7.50.

Smiling On (1930. 89 days.) - Fine medium height plant with five or more large very ruffled flowers open at a time. Fine rose pink, covering the entire flower very uniformly, excepting a very large and beautiful blotch of pure red in the center of all the lower petals. These blotches have the rose pink of the ground color extending 
down their sides setting out the blotches very effectively. A rich and showy new ruffled variety. Each, $\$ 2.00$. Doz., $\$ 20.00$.

Song of the Lark (1930. 90 days.)-Fine medium height plant and large flowers very evenly placed. Color a very fresh tone of salmon rose flaked softly a deeper orange salmon. Lower petals on outer portion of center, a soft creamy white, extending with a narrow central line of same color downward into the throat in a beautiful light bright rose red, divided by the white central median line. A very cheery and refreshing color and an outstanding and beautiful variety. Each, 75c. Doz., \$7.50.

Sprinkle (1930. 81 days.)-Fine height plant and large flowers, 6 to 8 or more open at a time. Ground color white, flaked daintily a lavender rose-pink, a little deeper towards the edges of all 6 petals. Beautiful feathered lavender and rose red center of lower petals, edged a delicate cream. A fine showy garden variety suitable for all pur-

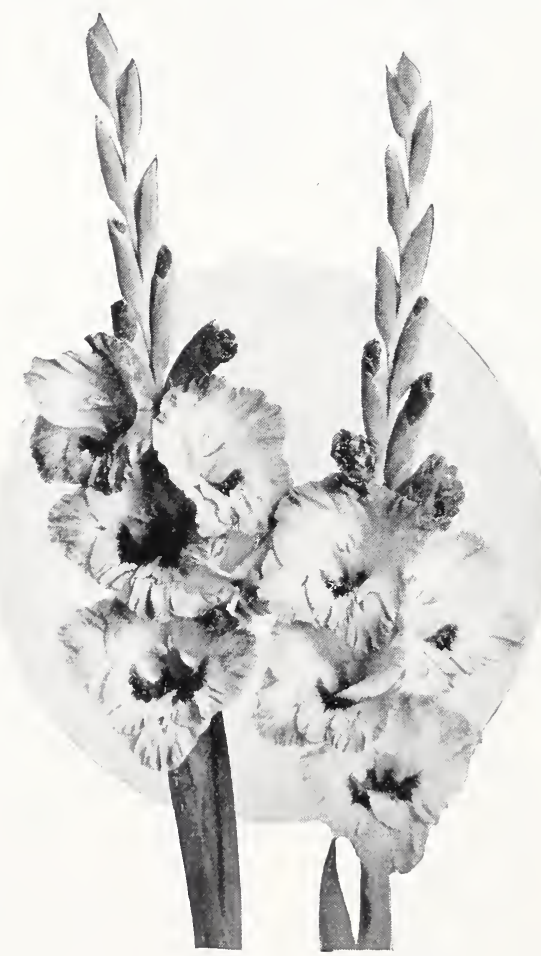

J. OGDEN ARMOUR-Described on Page 25

Rev, Mlfred I. M. Dove, Pennsylvania. "Each year I am becoming more pleased with your productions, and I have found them to be far superior to any others which I have. I believe this year I shall discard all but your bulbs." poses. Splendid. Each, \$1.00. Doz., $\$ 10.00$.

Tanager (1930. 73 days.)-Good height plant and good sized blooms. Form of flowers often upright. Color clear orange flaked slightly a deeper orange towards the outer portion. Throat beautifully golden orange edged beautifully with a bright lighter orange. Elegant and beautiful. Each, 75c. Doz., $\$ 7.50$.

Western Sunset (1930. 90 days.)-Medium tall, fine plant with 6 to 8 or more very evenly placed flowers open at a time. Color dark velvety blood red, flaked dark rose red at outer border of all the petals. Throat a little darker. Almost a perfect "self" color, showy, rich and beautiful variety. Each, 75c. Doz., \$7.50.

"Wonder Glory" (1930. 80 days.)-Very tall, very strong and massive plant and flower. Five or more immense massive flowers open at a time. Color richest deep golden cream daintily blushed, deepening towards the edges of the petals. Most of lower petals a dainty soft canary yellow with beautiful long feather bars extending half their length. Extra grand in every way and surpassed by no other variety in striking and showy appearance. I want to give my friends this rare treat with such a wonderful flower at a very moderate price of Each, $\$ 6.00$.

Vrs. II G. Hambrick, Texas, "I have just received $m y$ order of bulbs from you. They arrived in perfect condition. Many thanks for the generous extra one, 'Purple Queen' which you included. It certainly is a joy to grow Gladioli from your bulbs. They produce such large beautiful flowers and always true to catalog description. Because $I$ am such an ardent lover and grower of flowers (particularly Gladioli and roses) I can visualize the blooms from reading your catalog descriptions and am never disappointed. This year I am after the Garden Club prize with your Gladioli and feel quite confident of winning, having about 12 thirty foot rows of Kunderd Gladioli. Thanking you for past courtesies and wishing you the continued success which you deserve."

Mrs. Leon S. Briscoe, Arkansas. "I want you to know how thoroughly pleased I am with the Special collection of Glad bulbs I received from you this spring. They have bloomed and have such a gorgeous variety of colors. Many luflied. They have been a constant joy. My only regret is that I didn't order twice as many. I'm just home from my vacation and find a special Iris offer from you here but note that your time limit is Sept. 1st. I shall indeed be sorry if I am too late for a collection. Shall enclose check for $\$ 1.00$ hoping you will be able to fill it for I've found Kunderd Glads so satisfactory that I want to try Izunderd Iris also."

John A. Hobson, Kentucky. "I am just in receipt of your new catalog, which is a beauty. The Gladioli bulblets received from you last spring were so satisfactory and created such marked attention from my friends who would ask where I get such beautiful varieties, that I am sending below a list of flower lovers to whom you may send your catalog." 


\section{Collection Offers}

\section{RUFFLED INTRODUCTIONS}

These Collections Are All Sent with Each Variety Properly Labeled

Collection No. 6-All varieties valued at 75c, 8 in all (value $\$ 6.00)$ for.................. \$5.40

Collection No. 7-All varieties valued at $\$ 1.00,8$ in all (value $\$ 8.00)$ for.................. \$7.20

Collection No. 8-All varieties valued up to and including $\$ 1.00,16$ in all (value $\$ 14.00$ ) for... $\$ 12.60$

Collection No. 9-All varieties valued up to and including $\$ 2.00,23$ in all (value $\$ 28.00$ ) for .... $\$ 23.80$

Collection No.10-All varieties valued up to and including $\$ 3.00,24$ in all (value $\$ 31.00$ ) for.... $\$ 26.35$

Collection No. 11-Entire collection, one each of the 25 varieties listed (value $\$ 37.00$ ) for..........\$31.45

Varieties Included in These Collections Are Listed on Pages 16 to 20

Mrs. Daisy E. A. Booth, Wyoming. "Without a doubt your Glads surpass all others I have cver grown, and in the future $I$ intend to send all orders for my Gladiolus to you. My garden is simply gorgeous. I've tried hard to find out which one is the favorite, but have come to the conclusion that they are ALL favorites. Mr. Kunderd, I am happy to tell you that we had our Flower show last week and it proved to be quite a success, much better quality flowers were shown than ever before, but oh, the Gladioli belonging to other exhibitors were poor miserable things compared to those I was showing which I purchased from you. They were finely placed, good strong stems, fine coloring and possessed all the qualities that go to make attractive flowers. So is it any wonder that I walked off with all three prizes for the BEST glads shown? Over my stand was writtoen 'GROW KUNDERD GLADS THEN YOU WILL. BE GLAD,' and this exhibit was classed as the most attractive in the whole Flower Show.'

L. E. Brundage, Connecticut. "Both shipments of glad bulbs received, and I want to thank you for your generous substitution of the Pauline Kunderd, in place of the Nelson Shook. I feel sure that I will be more than satisfied with it. I also want to thank you for the gift of the Mrs. Frank Pendleton bulb which was enclosed in the last shipment. This was an agreeable and unexpected surprise. Although my orders to you were very small, it has been a pleasure to deal with you and I can easily see why your business has prospered as it has. I shall surely do some more business with you and I feel confident that my flowers this year will be all that I could desire,"

D. L. Amstutz, Indiana. "Just a word about the Glads. I have grown Kunderd Glads for the past ten years. In fact, I have never grown anything else, but this year they were the most wonderful of all. My Challengers grew sixty inches high with as many as twenty-one large beautiful flowers on one spike, and as many as seventeen blooms on a side spike after the main or center spike was cut off. I assure you at the Mishawaka Rubber \& Woolen Company where I work they attract a great deal of at tention, as I usually have a few of them on $m y$ table while I work. Kunderd's are good enough for me."

Mrs. A. II. Mokkenbrink, Missouri. "Indeed your bulbs are more than you claim for them, and I have gladly told the members of our Garden Club of the rare treat in store for them in your bulbs. I trust many of them have ordered. Am enclosing three orders for the mixed collection at $\$ 2.00$ each. The one for Mrs. Peterson, Troy, Kansas, is to fulfill the desire of her poor aged mother, to whom I sent you offer last year. She was richer with your blossoms than if I had given her a farm, for the beauty of life had been crushed out with poverty. She is eighty-five years old. You are doing a wonderful deed to enable people of moderate means to enjoy life's richest gifts. I know you will succeed."

Robert R. Amsden, Ohio. "Having purchased two of your special small bulb collections this spring, it may be very gratifying for you to know that I won the special prize ribbon given on Gladiolus cut flowers at the Recent Ash. Co. Fair held this last week. I exhibited 40 spikes cut from this collection and won over some very fast competition. Enclosed find picture taken of me in my Kunderd Glads. These bulbs are small when they arrive, but nearly every one has bloomed for me this first year. I am always a Booster for Kunderd Bulbs."

C. Harveyson, Queensland. "I would be very pleased to receive your latest catalog of Kunderd Gladioli. Previously I have been pur chasing your ruffled varieties locally, and think perhaps I could do better direct. Just a word of appreciation for Anthony Kunderd and Kunderdii Glory-we think they are wonderful here, and many a friend has admired them.' 


\section{Extraordinary Varieties of Ruffled Gladioli-Kunderdii}

This group contains the most famous varieties of ruffled gladioli the world has ever known. One need only to scan the list to tecognize such favorites as Purple Glory, E. J. Shaylor, Dr. Nelson Shook, Chalice Flower, Rose Glory, Crinkles and others. These varieties have become dear to the hearts of flower lovers in every civilized country. You cannot appreciate the beauty of the Gladiolus until you have seen and grown these magnificent ruffled flowers. Reduced prices make it possibie

for you to grow a greater number of these outstanding varieties.

A. E. Kunderd (1925. 88 days.) -Named for "The Originator of the Ruffled Gladiolus." It is a very strongly ruffled variety, tall and stately. A rapid multiplier. Color rich salmon-rose, lighter towards the center of throat with very beautiful markings on three lower petals. Illustrated on this page. Each, \$1.00. Doz., \$10.00.

Alton (1917. 80 days.) -A wonderfully ruffled variety of finest orange color. A magnificent gladiolus. Winner of

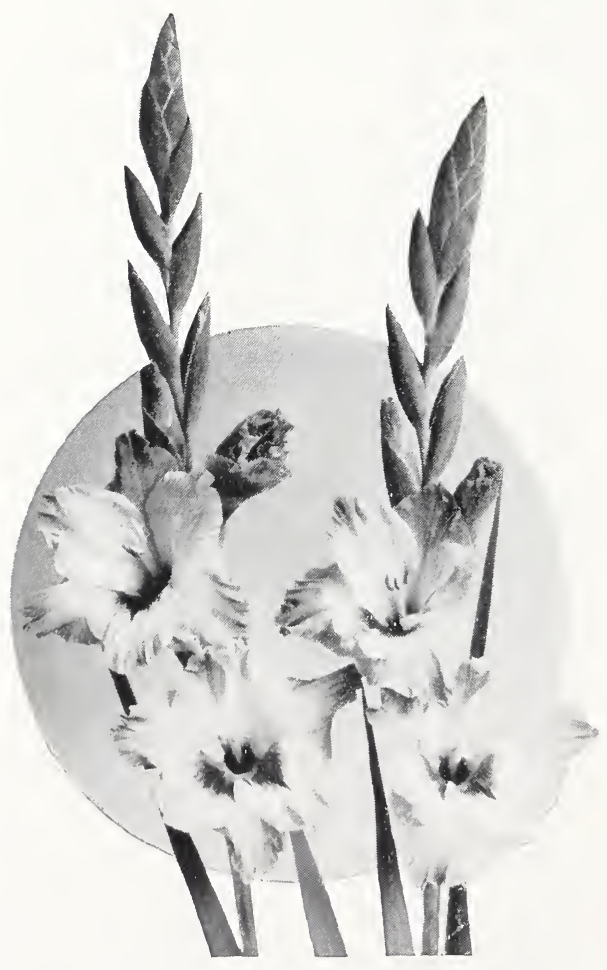

A. E. KUNDERD-Described Above many awards. Each, 20c. Doz., \$2.00. $100, \$ 15.00$.

Anthony B. Kunderd (1918. 86 days.)Tall, large, intensely ruffled flower of delicate, deep cream color. Overspread finest blush pink. Entire lower petals beautiful primrose-cream flushed pink at edges. Grand. Winner of many awards. Each 20c. Doz., \$2.00. 100, $\$ 15.00$.

Antione (1928. 67 days.)-Fine, upright plant. Flowers intermediate in type between large flowered and Primulinus. Color no doubt the richest deep yellow to be found in any gladiolus. A true, rich, deep, pure chrome yellow over entire flower and a pure self. A wonderful, very deep, pure spectrum yellow and first class in every way. Each, \$1.00. Doz., \$10.00.

Arcturus (1928. 66 days.) - A good, strong plant and good sized flowers of deep, rich sulphur yellow. Upper and lower petals a deep or golden canary yellow with blotches of red and deeper dark central bars. Each, 50c. Doz., $\$ 5.00$.

Aralon (1916. 71 days.) - An extra choice blush white with very beautiful red throat markings. A magnificent flower. Illustrated on page 32. Each, 15c. Doz., \$1.50. 100, \$11.25.

Beauty Wave (1927. 83 days.) - Rich shade of canary-yellow. Deeper on lower petals with finely feathered central bars. A sturdy, graceful plant. Flowers well ruffled. Each, 50c. Doz., $\$ 5.00$.

Blanche Bollinger (1925. 72 days.)-A pleasing and showy flower. Many large, medium ruffled flowers open at a time. A very distinct and pleasing shade of old-rose pink. Each, 20c. Doz., \$2.00. 100, $\$ 15.00$.

Blushing Beauty (1922. 88 days.)Opening buds blush pink, flower softest possible blush, many open. Dainty pink throat lines. Plant of good height. 
A marvel of daintiness and refinement. Each, 20c. Doz., \$2.00. 100, $\$ 15.00$.

Bridal Rose (1928. 83 days.)-Large, showy plant with large flowers of a rich rose pink. Lower petals have very beautifully red penciled throat on a delicate, creamy yellow ground. Central or median lined a refined deep red, veined and traced in beautiful, slight thread lines of same color. Each, 50c. Doz., $\$ 5.00$.

Buckeye (1921. 78 days.)-Very large, massive bloom of fine rose-pink color with tint of old-rose at edge of petals. A beautiful, large rose-red throat. Very good. Each, 15c. Doz., \$1.50. 100, $\$ 11.25$.

Cattleya Rose (1928. 70 days.) - Fine height of spike and stately plant. Large flower of beautiful cattleya rose color and exquisite form. Lower petals of a dainty pastel yellow color onehalf way and outer one-third of petals of same color as upper petals. Central part of lower petals have neat median line of deep maroon or wine red, traced and feathered at sides with same color. A very orchid-like and beautiful variety. Each, \$1.00. Doz., \$10.00.

Chalice Flower (1924. 74 days.)-A tall, beautiful plant with a very refined and elegant flower. Flowers large and plenty open at a time. Cup of roundish form, suggestive of its name. Color of light, creamy blush white of pleasing effect. Very artistic and beautiful. This variety won A. G. S. Trophy, 1926, for best funeral spray of white gladioli. It also won two other First Prizes for the best flesh colored variety exhibited at the same show. Illustrated on this page. Each, 25c. Doz., \$2.50. $100, \$ 18.75$.

Charm (1921. 81 days.)-Pure, deep rose-pink. A large and wonderful flower of beautiful shades, perfectly harmonized. A perfect blotch of deep red on lower petals. Grand and distinct. Each, 20c. Doz., \$2.00. 100, $\$ 15.00$.

Chicago (formerly named Luther Burbank) (1927. 69 days.) - A marvelous new ruffled gladiolus. Tall, fine plant with six or more magnificent, large blooms open at a time. Deep geraniumred. Border of all petals has a narrow line of a delicate bluish shade. Lower petals are beautifully feathered deeper red. Throat in upper portion of each flower is blended lighter. Several years ago I had wished to name this variety for myself as the originator of the ruffled type of gladiolus but as it was then in too limited supply I did not do so. Illustrated on page 87. Each, $\$ 5.00$. Doz., $\$ 50.00$.

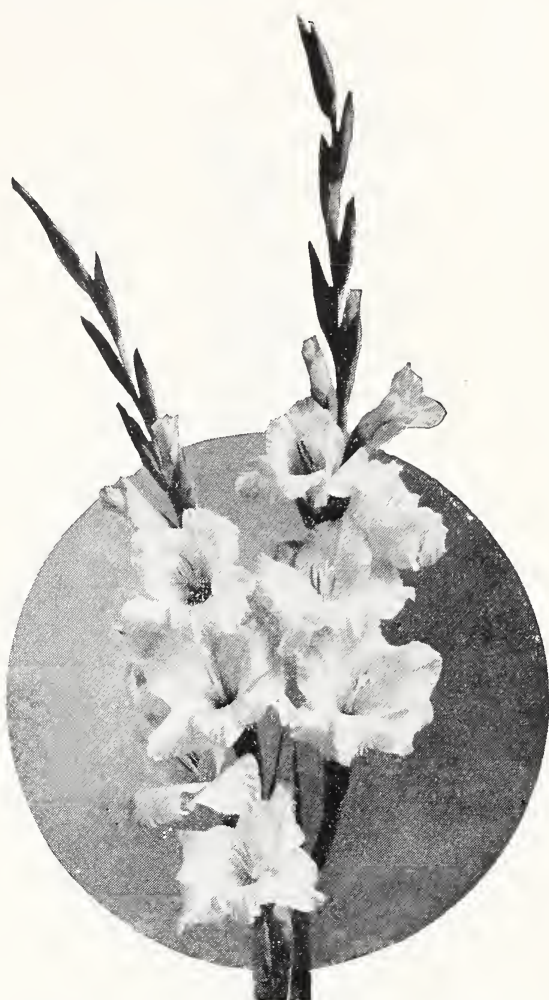

CHALICE FLOWER-Described on This Page

Color Marvel (1928. 80 days.)-Plant of fine height and appearance. Flowers large and grandly ruffled. Color a glowing deep varmilion scarlet. Lower petals much darker all over with very dark, velvety central narrow bars or median line. This is a flower equal in beauty and richness of color to an extra fine pansy and no variety can surpass it in richness of color. Very beautiful. Each, \$3.00. Doz., \$30.00.

Contemplation (1928. 94 days.) - Tall, strong plant with very large massive and heavily ruffled flowers. Color delicate lavender rose pink on a white ground and deeper on lower petals. Lower petals a deeper rose pink with showy red pencilings and terminating yellow. Each, \$3.00. Doz., \$30.00.

Coral Pink (1928. 69 days.) - Tall plant and large, finely ruffled flowers of a clear, deep coral pink. Lower petals same color at the edges but with a blotched, soft apricot yellow throat and feathered central bars. An exceptionally fine new ruffled gladiolus. Illustrated on page 53. Each, 75c. Doz., $\$ 7.50$.

Crinkles (1916. 92 days.)-Deep peachblossom pink. Intensely ruffled. At Mid-western gladi ol us Show, Des

\section{A. E. Kunderd, Goshen, Indiana}




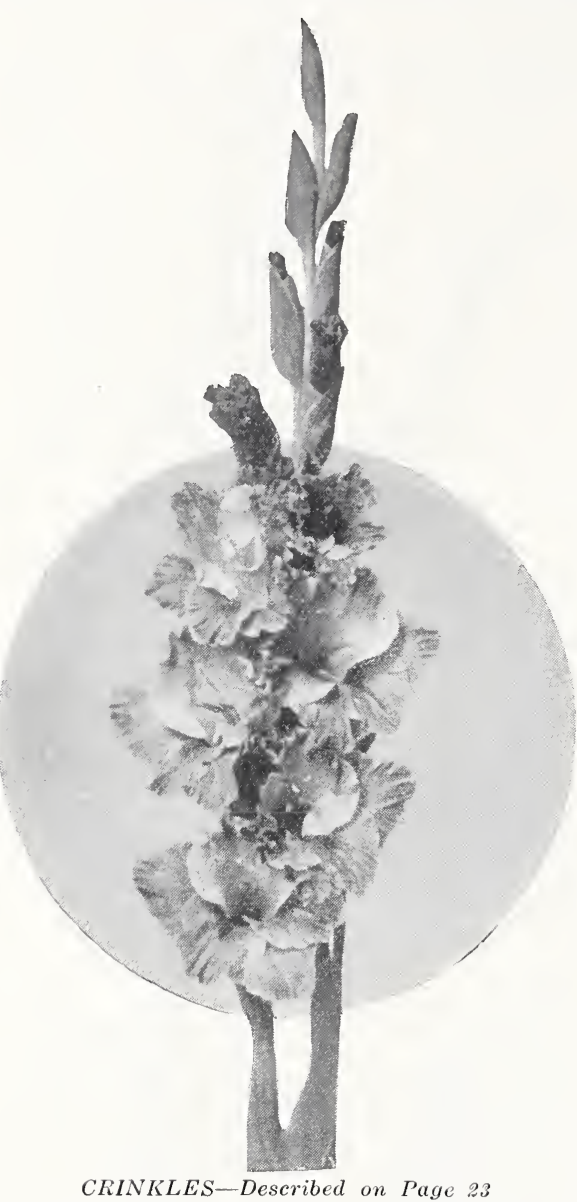

Moines, Sept., 1925, awarded first prize for best ruffled gladiolus, and first for best dark pink variety. Crinkles has never been produced in quantity to meet popular demand. It is one of the most outstanding varieties. Illustrated cn this page. Each, 35c.

Dr. Crist Martz (1925. 79 days.) - A large and beautiful flower of light blood-red. A very showy ruffled variety. Each, 35c. Doz., \$3.50. 100, $\$ 26.25$.

Dr. L. H. Bailey (1927. 72 days.) - Six to eight very large blooms open at a time on strong spike and plant. Rich, velvety tyrian rose. Throat in upper portion lighter and on lower petals very much deeper red velvety blotches. Extremely fine. Named in honor of the great horticultural authority of Cornell. Stock very scarce. Each, \$3.00. Doz., \$30.00.

Dr. Nelson Shook (1925. 78 days.)-A giant in plant and flower. Color of deep tyrian rose. This variety created a sensation at the A.G.S. show, Rochester, Aug., 1925, and was the most talked of variety of the many thousands displayed. It also won A. G. S. Bronze Medal for best basket gladioli exhrbition type; Trophy for best floor basket of gladioli; First prize for spike showing the greatest number of florets open; also, together with a basket each of Sweet Rose, Tiger, Helga and Kunderd's Yellow Wonder won the Executive Committee's Silver Cup for the five best baskets of gladioli. Illustrated on page 87. Each, 75c. Doz., \$7.50.

Dream (1918. 86 days.)-Large, massive bloom. Deep salmon-red. Large, very showy blotches. Extra grand. Each, 15c. Doz., \$1.50. 100, \$11.25.

E. J. Shaylor (1918. 71 days.)-Tall, very strong plant and large blooms. A beautiful, pure, deep rose-pink. Was awarded Certificate of Merit by Royal Horticultural Society of England, Aug. 10, 1920. Each, 10c. Doz., \$1.00. 100, $\$ 7.50$.

Elba (1917. 77 days.) - A very largeflowered, deep lavender-rose. Deeper throat. Showy. This variety was arranged in funeral basket together with "Blanche Bollinger" and "White Butterfly" at the A. G. S. show, Rochester, Aug., 1925, and was awarded first prize, A. G. S. Trophy. Each, 25c. Doz., $\$ 2.50$. 100, \$18.75.

Evening Glory (1926. 83 days.)-Tall, graceful plant and flower. Throat markings same as in Kunderdii Glory, but color of a very fine shade of light rosepink. A beautiful and distinct, new, ruffled variety. Another fine addition to the Glory family. Illustrated on page 52. Each, 25c. Doz., \$2.50. 100, $\$ 18.75$.

Favorite (1921. 83 days.) - Beautiful orange-salmon, deeper in throat. Tall, strong, vigorous plant with many large, finely ruffled flowers open at a time. Very fine. Illustrated on inside front cover. Each, 25c. Doz., \$2.50. $100, \$ 18.75$.

Fern Kyle (1921. 77 days.) -A large, ruffled flower of creamy white color. Vigorous grower. Creates a sensation wherever shown. Introduced at $\$ 25.00$ per bulb. Awarded first prize as best cream colored variety at A. G. S. show, Rochester, Aug., 1925. Illustrated on page 54. Each, 35c. Doz., \$3.50. 100, $\$ 26.25$.

Glorious (1921. 75 days.) - Tall, strong plant. Many blossoms open at a time. Soft cream color with deepest creamy apricot throat, beautifully marked. Extra choice. Illustrated on page 51. Each, 20c. Doz., \$2.00. 100, $\$ 15.00$.

Golden Anniversary (1929. 101 days.)Tall, strong and stately plant bearing 
giant perfectly placed flowers, of a beautiful fawn yellow with a suffused blush of pink. The throat has a large nicely proportioned blotch of glowing red, beautifully blended at its edges. The entire flower is well ruffled, very showy and distinct. Named in honor of the Golden Anniversary of my business. Each, \$5.00.

Golden Beauty (1928. 80 days.)-Large, showy, wide open, very deep daffodil yellow. Lower petals still deeper golden yellow with slight, beautiful, bright red central bars. Golden yellow ruffled variety extra grand. Each, \$2.00. Doz., \$20.00.

Golden Brown (1929. 72 days.) - Fine good height plant with beautiful ruffled flowers of a good size. Color deep mahogany red on outer portion, with a pure brown marking in throat. Ground color in throat. A golden brown suggesting its name. A very rich brown gladiolus. Each, $\$ 2.00$. Doz., $\$ 20.00$.

Golden Glory (1916. 79 days.) - A large, richly colored yellow, with beautiful throat. A fine, ruffled yellow. Each, 15c. Doz., \$1.50. 100, \$11.25.

Golden Robes (1928. 69 days.) - Upper petals a mellow tone of fine daffodil yellow. Lower petals a deeper daffodil yellow. Very light center pencil lines of brownish red or pink. A rich and dainty yellow with finely ruffled petals. A coming florists' yellow. Each, 20c. Doz., \$2.00.

Golden Salmon (1925. 81 days.) - A truly wonderful, ruffled gladiolus of beautiful golden-yellow and salmonred or pink shades beautifully blended. An extra choice and distinct kind. Very unusual and grand. Each, 75c. Doz., $\$ 7.50$.

Harmonia (1928. 80 days.) - Strong plant of good, medium height. Flowers large and of a very decided and glowing, rich, deep orange-red color. Lower petals have narrow central bars with a whitish median line which is bordered with a bluish maroon narrow line on either edge. The whole flower similar, but deeper in color than "Orange Glory" and fully as showy, or more so. A very fine orange. Each, \$1.00. Doz., $\$ 10.00$.

Hermes (1923. 90 days.)-Large, strong plant. Very large, deep, cherry-rose flower with deeper rose on lower petals. Heavily ruffled. A grand variety. Each, 15c. Doz., \$1.50. 100, \$11.25.

Indianapolis (1916. 80 days.)-Verv tall, fine deep violet; deeper throat. Slight white median lines. Beautiful. This variety was withdrawn from my list several year's ago to increase the stock, as it is unusually popular and the stock

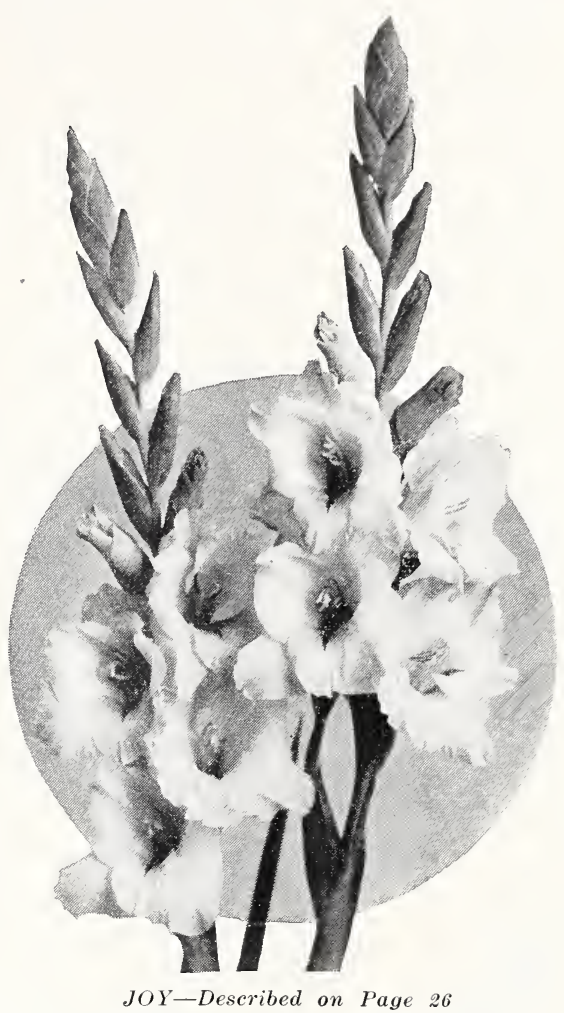

was sold too close. Each, 20c. Doz., $\$ 2.00$. 100, $\$ 15.00$.

Indian Summer (1917. 116 days.) - A cross between a "Kunderdii" variety and species "Quartinianus." The forerunner of a new class of gladioli. Full size bulbs produce strong spikes with six to eight very massive ruffled flowers open at a time. Color a blush or light lavender rose-pink on a white ground. Very distinct flower and in general appearance very showy. Especially valuable to the gladiolus breeder, as it is a seed-bearing "hybrid." Each, 50c. Doz., $\$ 5.00$

Intensity (1928. 92 days.)-Strong, vigorous plant with large, massive, widely open flowers. Color rich, deep, bright red, darker toward outer portion. Fine rich, deep red feathered median line on lower petais. Strongly ruffled and one of the very finest ruffled varieties. Each, 75c. Doz., \$7.50.

J. Ogden Armour (1926. 80 days.) - Tall plant with many large, beautifully placed flowers open at a time. Color of a bright coral salmon-red, lighter in the upper portion of the throat. Lower petals have large, elegant and conspicuous dark-red throat blotches. A showy and distinct new ruffled gladi-

\section{A. E. Kunderd, Goshen, Indiana}


olus of orchid-like appearance. Illustrated on page 20. Each, 25c. Doz., $\$ 2.50$. $100, \$ 18.75$.

Joy (1923. 85 days.) - Extra fine, purest flesh color with daintily tinted soft canary or cream throat, finely marked pink. Very unusual and fine. Illustrated on page 88. Each, 20c. Doz., \$2.00. 100, $\$ 15.00$.

Juno (1928. 76 days.) (Kunderd's.)Fine plant with medium large, perfectly open flower. Color a beautiful apricot with very rich, subdued red throat blotch with fine, deeper red central bars. Upper petals a soft cream daintily blushed, with ends of petals a fine tint of pink and very upright and open. Very pretty for all purposes. Each, 75c. Doz., \$7.50.

Kasson (1917. 73 days.)-Large, lavender rose-pink with deeper rose-pink throat. Finely ruffled. Each, 10c. Doz., $\$ 1.00$. $100, \$ 7.50$.

Kunderdii Glory (1907. 77 days.) -Beautiful, creamy apricot with light tint of pink, and fine markings of red on lower petals. Can be grown over five

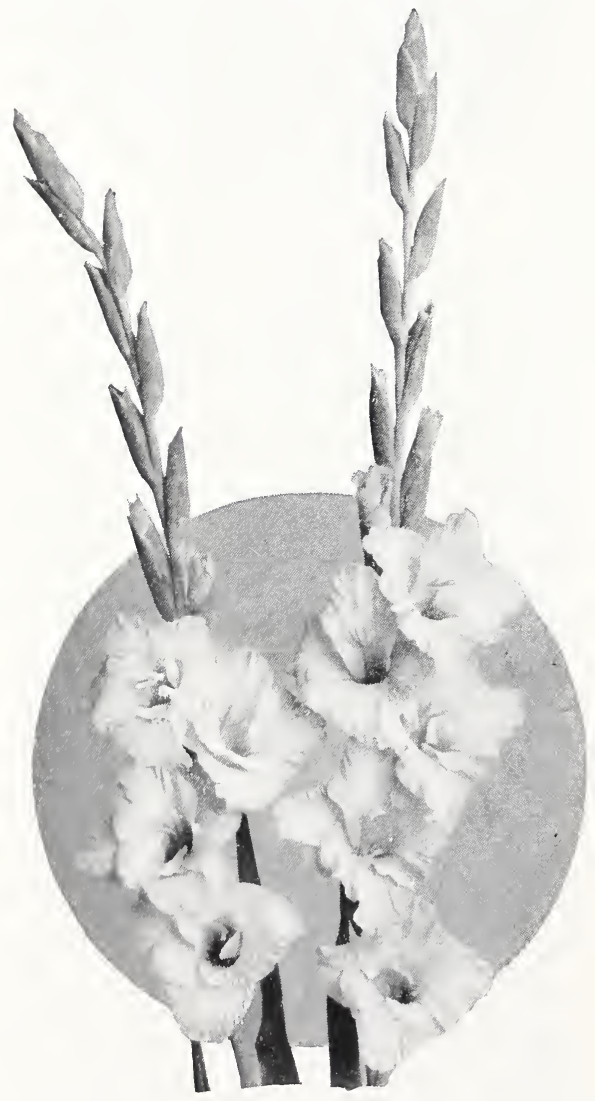

SULPHUR FRILLS-Described on Page 29 feet tall with high culture. This is the first scientifically produced Ruffled Gladiolus ever sent out. It has received many certificates and awards, is known all over the world, and is the parent of many new varieties. Each, 10c. Doz., $\$ 1.00$. 100, \$7.50.

K underd's Apple Blossom (1923. 77 days.) -Apple blossom color. Tall, fine plant and spike. Very refined and beautiful. Each, 15c. Doz., \$1.50. 100, \$11.25.

Kunderd's Wild Rose (1927. 83 days.)Tall, strong, massive plant with many large and intensely ruffled flowers open at a time. Color beautiful, wild-rose with lavender tint. Throat deeper lavender. An exceedingly choice, new introduction. Heavily ruffled. Each, 25c. Doz., \$2.50. 100, \$18.75.

Lavender Pride (1928. 79 days.)-Fine, tall plant, large, wide open flowers of a deep, lavender rose color, beautiful throat of a deeper rose or purplish lavender rose. A splendid and showy flower in good supply. Each, 25c. Doz., $\$ 2.50$. $100, \$ 18.75$.

Lela (1928. 69 days.) - Fine plant with good sized flowers and beautifully ruffled. Upper petals dainty cream very daintily blushed softest flesh pink. A soft, deep creamy apricot over entire lower petals, with only a delicate pink slight central bar on inner portion. Very fine. Each, 75c. Doz., \$7.50.

Lilac Glory (1923. 84 days.)-Large flowers, many open. Soft lilac rose-pink. Beautiful, deeper lilac rose and pink throat. Kunderdii Glory type. Illustrated on page 88. Each, 20c. Doz., $\$ 2.00$. $100, \$ 15.00$.

Lilith (1918. 79 days.) - Color orangesalmon. Heavily ruffled. Good height, average four or five flowers open; one of the best ruffled varieties. This variety had to be withdrawn from my list for a number of years to increase stock. Each, 35c. Doz., \$3.50. 100, $\$ 26.25$.

Lily of Gold (1928. 66 days.) - A sturdy, straight plant of medium height. Flowers five and six or more open at a time and very large and of wide open diamond form. Gracefully and widely open upper petals. Upper central petal extremely large and upright, giving the flower a very striking appearance. (Flowers very evenly and perfectly placed.) In every way a remarkable and wonderful flower. Many who have seen it in flower pronounce it the greatest of all Gladioli. Scarce, but a very rapid multiplier. Color, rich canary yellow, a little deeper on lower petals. Each, $\$ 10.00$.

Maimonides (1928. 83 days.) - Fine, strong plant. Flowers large and massive and facing perfectly one way. Color pure snow white on all six pet- 
als. Lower petals have a showy and beautiful blotch of red. The entire flower is intensely ruffled, very showy and distinct. Each, \$3.00. Doz., \$30.00.

Marshal Foch (1922. 84 days.)-One of the sensations at the American Gladiolus Society's show in August and wherever shown at the big exhibitions. Many giant flowers open at a time on very strong stem and plant. Color of finest salmon-pink. Almost self-color. Each, 15c. Doz., \$1.50. 100, \$11.25.

Marie Kunderd (1918. 69 days.) - A wonderful white, very early. Of purest white with an almost invisible soft pink line in center of lower petals. Grandest of all whites. Awarded First Class Certificate of Merit by North Shore Horticultural Society, Manchester, Mass., summer of 1919. Blooms of this variety worked into a beautiful bride's bouquet and displayed at the A. G. S. show, Rochester, Aug., 1925, awarded first prize A. G.S. Bronze Medal. First prize was awarded this variety at the $1926 \mathrm{~A}$. G. S. show as the best white variety. Also at the same show, it was used in my cross design with Purple Queen and won another A. G. S. Trophy. Illustrated on this page. Each, 35c. Doz., \$3.50. $100, \$ 26.25$.

Masterpiece (1921. 81 days.) - A magnificent ruffled "American Beauty" rose color. Giant flower and plant. Extremely fine. Each, 20c. Doz., \$2.00. $100, \$ 15.00$.

Mona Lisa (1917. 78 days.) - Strong plant. Many flowers open at a time. Of palest soft rose-pink, or blushed white. A magnificent, almost pure selfcolor. One of the most delicate and refined shades ever produced. Each, 15c. Doz., \$1.50. 100, \$11.25.

Moravian (1928. 71 days.) - Neat plant and good sized flowers neatly placed on spike. Medium well ruffled. Color a very pretty shade of lavender with fine veins and tracings on lower petals on a soft creamy yellow ground. Outer portion of petals shaded deeper lavender. A very pretty and pleasing variety. Each, 20c. Doz., \$2.00. 100,\$15.00.

Natalie (1923. 84 days.) - Finest, deep orange-salmon. Deeper color on lower petals. Neat, short white line extending from throat markings. A beautiful and distinct variety. Tall, fine plant and showy flower. Each, 10c. Doz., $\$ 1.00$. $100, \$ 7.50$.

Ne Plus Ultra (1928. 74 days.)-Tall, fine plant with a large, elegantly ruffled flower of most beautiful deep, rich cream in color and has a lovely marking of fine red and finelv penciled central base. One of the most beautiful varieties ever produced and fine for

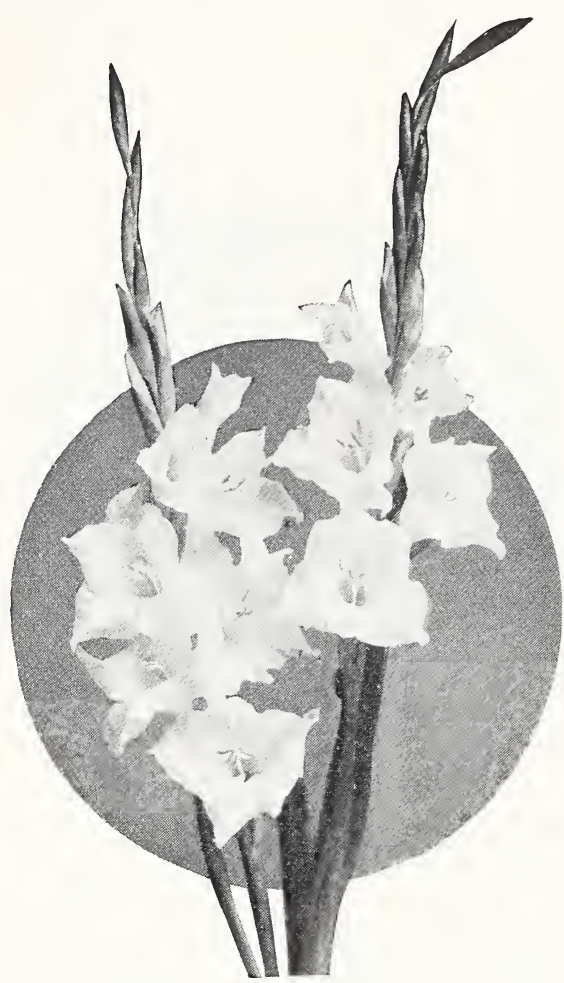

MARIE KUNDERD-Described on This Page

every purpose. Very beautiful. Each, $\$ 1.00$. Doz., \$10.00.

New York (1928. 76 days.) - A fine plant and large flowers. Wide open and upper petals beautiful, upright. Color a rich rose red and lower petals have a fine, deep red blotch. A very fine and beautifully ruffled variety. Sure to please. Each, 50c. Doz., \$5.00. 100, \$37.50.

Oran (1918. 80 days.)-Blushed white, a little deeper than "America." Rose and white penciled throat. Illustrated on page 18. Each, 15c. Doz., \$1.50. $100, \$ 11.25$.

Orange Fire (1929. 74 days.) - A medium sized plant and flower with pure clear deep orange vermilion flowers. Slightly lighter in upper portion of throat. Lower petals are a fiery orange with neat dark velvety red bars. Richest orange color imaginable. A beautiful orange red. Each, \$2.00. Doz., \$20.00.

Peep O’Day (1921. 79 days.) - Tall, beautiful blushed pink on white ground. Long, feather barred throat. Grand. Each, 20c. Doz., \$2.00. 100, \$15.00.

Pink Cloud (1923, 77 davs.) - A large, distinct, showy, ruffled variety. Usually seven to nine beautiful, soft rose-pink blossoms open at a time. A very beautiful, deeper rose throat. A distinct 


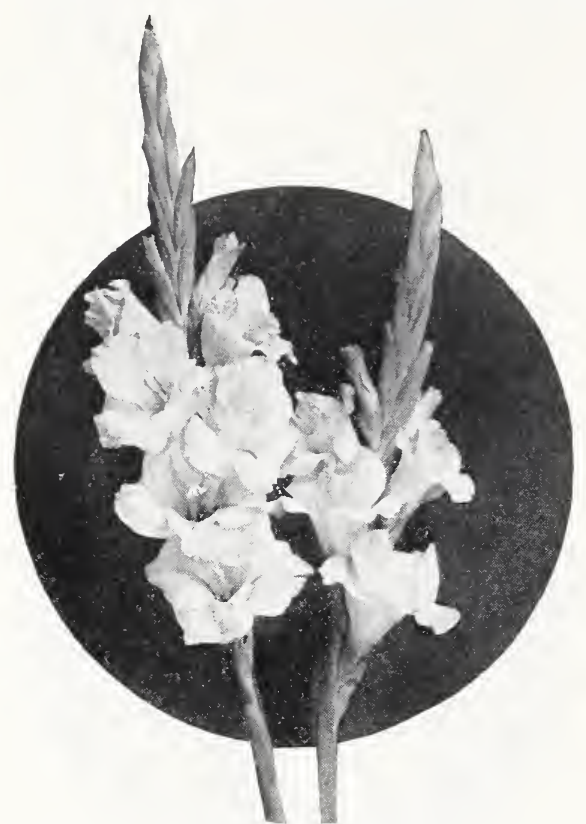

PRIDE OF GOSHEN-Described on This Page

introduction. Received first prize at the 1926 A. G. S. show as the best pink variety exhibited. Each, 25c. Doz., $\$ 2.50$. 100, $\$ 18.75$.

Pink Lily (1916. 77 days.)-A magnificently ruffled rose-pink. Grand. Each, 20c. Doz., \$2.00. 100, \$15.00.

Pride of Goshen (1915. 85 days.) - A giant "Kunderdii Glory" of a salmon or flesh-pink. Flower's very large and petals elegantly waved. Exceptionally tall and vigorous plant. General appearance imposing. Illustrated on this page. Each, 15c. Doz., \$1.50. 100, $\$ 11.25$.

Primora (1928. 76 days.) - Tall, fine, strong plant. Flowers large and showy and wide open, upper petal upright. Color a delicate rose pink on a blush white ground considerably deeper pink towards outer edges of all the petals. Lower petals have a beautiful rosered blotch nicely feathered with beautiful deeper red central bars. An extra fine ruffled variety. Each, 75c. Doz., $\$ 7.50$.

Purple Glory (1916. 79 days.) - The giant of the Kunderdii Glory race, and of remarkable color. Deepest velvety maroon-red, with almost black blotches, like burned into petals. Beautifully ruffled. Extraordinary. This variety was awarded silver cups at two different shows for "Best variety at the show," and several medals during 1923. Awarded first prize A. G. S. show, Rochester, Aug., 1925, in the dark-red and maroon class. Winner of hundreds of other awards. Each, 20c. Doz., \$2.00. 100, $\$ 15.00$.

Purple Queen (1925. 73 days.)-A deep violet-purple beauty. Throat darker. medium ruffled. Very extra of this shade. A wonderfully arranged funeral piece of this variety was exhibited by me at the A. G.S. show, Rochester, Aug., 1925, and was awarded first prize, A. G.S. Bronze Medal. Winner of two trophies and two other first prizes, 1926 A. G. S. show. Illustrated on page 88. Each, 35c. Doz., $\$ 3.50$. $100, \$ 26.25$.

Quantico (1929. 80 days.)-Strong vigorous plant of good height with five or more large massive blooms open at once. Color fine rose pink over all six petals. Lower petals have large bright deep red blotches on clear creamywhite ground. Reminds one of a ruffled "Pendleton." Each, 35c. Doz., $\$ 3.50$.

Red Ribbon (1928. 84 days.)-Tall, fine plant, large flowers on strong, nice stems. Color deep rhodamine purple red. Throat deeper red. Upper portion of throat much lighter than the main portion of petals. Beautiful flowers beautifully placed and finely ruffled. Each, 35c. Doz., \$3.50. 100, \$26.25.

Red Splendor (1928. 77 days.)-Strong, good height plant, with large and massive wide open flowers. Lower petals almost as large as upper ones. Color a decidedly brilliant scarlet with lower petals a deeper, rich velvety red of the ruffled type, but only moderately ruffled. A different, gorgeous and showy red. Very extra. Each, \$1.00. Doz., $\$ 10.00$.

Reo (1929. 80 days.)-Tall grand plant. Flowers large and of a distinct deep dark ruby red. Medium ruffled. A grand deep red of very distinct and attractive appearance. Each, 50c. Doz., $\$ 5.00$.

Rosalind (1918. 70 days.)-Dark, analine-red, deeper throat. Very popular and often spoken of as one of my best productions. Distinct and grand. Each, 20c. Doz., \$2.00. 100, \$15.00.

Rose Glory (1916. 77 days.) - A very large and beautiful ruffled variety. Purest rose - pink color. Deeper in throat. Extra fine. Winner of hundreds of awards. Illustrated on page 51 . Each, 10c. Doz., \$1.00. 100, \$7.50.

Ruffled Splendor (1928. 72 days.)-Medium tall and very vigorous plant. Flowers very large with five or more massive, perfectly placed blooms open at a time. Upper petals and ends of lower petals of a decidedly rich and showy, pure, self colored, deep salmonrose pink. Throat blotches extremely showy and fine, over the entire breadth 
of the broad lower petals. The blotches are beautifully penciled with fine veins of beautiful red with dark velvety red central bar or median line. The blotches are more showy than in "Pendleton." Few gladioli can equal it. Each, $\$ 1.00$. Doz., $\$ 10.00$.

Ruth Huntington (1923. 82 days.)Beautiful violet lilac with deeper lilac markings on lower petals. Large, strong plant with tall, fine spikes. A general favorite. Illustrated on inside back cover. Each, 15c. Doz., $\$ 1.50$. 100, $\$ 11.25$.

Salmon Plume (1921. 69 days.)-Clear salmon flesh, deeper at edges of petals. A pretty red throat. Choice. Each, 15c. Doz., \$1.50. 100, $\$ 11.25$.

Scarlet Glory (1917. 86 days.)-In plant and flower $\mathrm{much}$ like "Kunderdii Glory." but not so deeply ruffled. A very fine red, of rich, distinct shade. Each, 15c. Doz., \$1.50. 100, \$11.25.

Smiles (1921. 82 days.)-Large flower of the Glory type. White petals with fine rose-pink on outer edges. Splendid. Each, 15c. Doz., \$1.50. 100, \$11.25.

Snow Glory (1917. 80 days.) - Of purest all white, with only slight clear irisblue lines on lower petals. Very large and very showy. A wonderful flower. Winner of many awards. Each, 50c. Doz., \$5.00.

Star Lily (1929. 84 days.)-Tall strong vigorous plant and giant flowers of a deep sulphur or light canary yellow. Lower petals only a little deeper canary yellow without any other coloring or markings. Strongly ruffled. A magnificent giant self colored variety. An extra fine "self." Each, 75c. Doz., $\$ 7.50$.

Sulphur Frills (1923. 76 days.)-Tall, many medium sized flowers open at a time. Beautifully ruffled, of finest, pure, soft, sulphur shade. A real wonder. Illustrated on inside óack cover. Each, 25c. Doz., \$2.50. 100, \$18.75.

Sulphur Glow (1921. 74 days.) -A beautiful shade of sulphur-yellow. Many well-expanded, intensely ruffled flowers open at a time. Each, 20c. Doz., \$2.00. $100, \$ 15.00$.

Tempa (1917. 80 days.)-Pink ground. Old rose, bronzy lavender throat. Distinct and fine. A popular variety at the A. G. S. show, Rochester, Aug., 1925. Each, 15c. Doz., \$1.50. 100, $\$ 11.25$.

Thistle (1921. 77 days.)-Large, rosered flower of very open and perfect form. Pretty, large pansy-like throat markings. Tall, stately plant, extra choice. Each, 20c. Doz., \$2.00. 100, $\$ 15.00$.

Thomas A. Edison (1929. 77 days.)-An extraordinary gladiolus named by spe- cial permission of the great wizard of inventions. Color an unusually velvety, dark blood-red. A very large and perfectly placed wide open flower-wonderfully formed and heavily ruffled. Six and seven open at a time. This variety is always greatly admired by visitors, and I am sure it will eventually be found in every first-class collection of gladioli. Very few for sale this season. Illustrated on page 87 . Each, \$5.00. Doz., \$50.00.

Tippecanoe (1929. 97 days.)-Good fine strong plant with numerous large wide flowers open at a time. Color is "America" over again with a similar feather bar a little larger on lower petals, and the flower is beautifully ruffled. This variety won the first prize for best new seedling when shown in 1925 at the Mid-Western Gladiolus Society Show held at Des Moines, Iowa. Each, 50c. Doz., \$5.00.

Twilight (1921. \&5 days.) - Beautifully blushed creamy-buff with throat of grandest yellow and pink. Magnificent. Illustrated on page 18. Each, 20c. Doz., $\$ 2.00$. $100, \$ 15.00$.

Violet Glory (1916. 70 days.)-Massive flower. Rich, self-color deep violet; deeper throat. Medium ruffled. Extra.

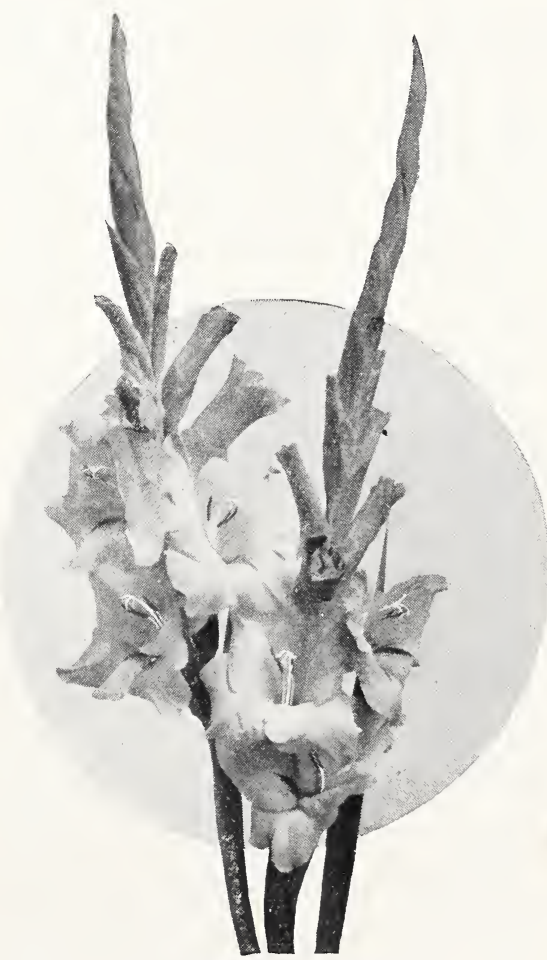

YOUELL'S FAVORITE-Described on Page 30 
Illustrated on page 87. Each, 20c. Doz., \$2.00. 100, \$15.00.

White Glory (1915. 79 days.) - A gorgeous, pure white of exact size and type as "Kunderdii Glory," with beautiful iris-blue throat. Fine as a delicate iris. Grand. Winner of many awards. Each, 20c. Doz., \$2.00. 100, $\$ 15.00$.

Youell's Favorite (1915. 95 days.)-One of Henry Youell's (Sec'y Am. Gladiolus Society) favorites among our ruffled varieties. Large flower and plant. Striking rosy lavender-pink. Conspicuous and fine. Illustrated on page 29. Each, 15c. Doz., \$1.50. 100, \$11.25.
George Pommer, Jr., Minnesota. "Every Kunderd Glad bulb I bought and planted this year grew magnificently and produced a superb flower (in some instances two from one bulb). This I think proves conclusively the superiority of Kunderd Gladioli. I noticed also that every grower of Gladioli who is a true lover of the flower, has various select varieties from Kunderd in his collection. Kunderd Glads are universal."

Mrs. G. H. Yarrington, New York. "I want to tell you we had a Gladioli show here last year. I was delighted to receive fifteen first prizes on Kunderd's Gladioli. I never buy anywhere else, as I am so pleased with your bulbs. As I compared the blossoms with others at the show, I think they are like some people who have individuality. I did not see any blossoms that were so fine and large."

\section{Collection Offers GLADIOLI-KUNDERDII}

These Collections Are All Sent with Each Variety Properly Labeled

Collection No. 12-All varieties valued up to and including $15 \mathrm{c}$, 21 in all (value $\$ 2.90$ ) for........ \$2.60

Collection No. 13-All varieties valued up to and including 20c, 42 in all (value $\$ 7.10$ ) for.........\$6.40

Collection No. 14-All varieties valued up to and including $25 \mathrm{c}$ 51 in all (value $\$ 9.35$ ) for ........ \$8.40

Collection No. 15-All varieties valued up to and including 35c, 59 in all (value $\$ 12.15$ ) for.......\$10.95

Collection No. 16-All varieties valued up to and including 50c, 67 in all (value $\$ 16.15$ ) for.......\$14.55

Collection No. 17-All varieties valued up to and including 75c, 75 in all (value $\$ 22.15$ ) for........\$18.85

Collection No.18-All varieties valued up to and including $\$ 1.00,82$ in all (value $\$ 29.15$ ) for... $\$ 24.80$

Collection No. 19-All varieties valued up to and including $\$ 2.00,85$ in all (value $\$ 35.15$ ) for... $\$ 29.90$

Collection No. 20-All varieties valued up to and including $\$ 3.00,89$ in all (value $\$ 47.15$ ) for... $\$ 40.10$

Collection No.21-All varieties valued up to and including $\$ 5.00,92$ in all (value $\$ 62.15$ ) for... $\$ 52.85$

Collection No. 22-Entire collection, one each of the 93 varieties listed (value $\$ 72.15$ ) for.......\$61.35

Varieties Included in These Collections Are Listed on Pages 22 to 30

Take Advantage of My Offer for Early Orders-See Page 12 


\section{New Plain Petaled Varieties}

\section{for 1931}

The term "plain petaled" is certainly a misnomer when applied to these magnificent Gladioli. The petals are by no means plain for in this group are to be found the widest possible range of colors, the most beautiful shapes and the most delicate blendings of shades and combinations. Some of the outstanding varieties are to be found among the so-called "plain petaled" kinds. If you will notice the illustrations you will observe that the petals are not ruffed but appear to be smooth. The effect is very artistic and beautiful. My 1931 Introductions bid fair to become universal favorites.

Agnes Ball (1931)-Fine, medium tall plant with ample blooms open at a time. Color most beautiful red with very large white throat. This is a pure self fertilized seedling of "Princeps" of better and purer colors. The best Princeps seedling which I have ever seen. A grand garden and show variety. Each \$5.00. Doz., \$50.00.

Aglow (1931) - Fine height plant and medium size flowers of a very pleasing fresh colored, bright rose pink. Faintly flaked a little deeper on outer edge of petals. Lower throat a clean, clear, self colored creamy . white harmoniously blended. A delightful and pretty flower. Each, \$1.00. Doz., \$10.00.

Anna Mae (1931) - Tall strong plant. Flowers large and plenty open at once. Color a creamy white, faintly blushed flesh pink over outer portion of petals. Lower portion of throat a soft canary yellow or deep cream. Colors finely blended. A showy and pleasing flower. Slightly ruffled. Each, \$1.00. Doz., $\$ 10.00$.

Booth Tarkington (1931)-Strong good height plant and large flower with ample blooms open at a time. Colors bright rich Tyrian rose pink with delicate lavender purple blush. Lower petals a deeper rose pink with still darker rose red narrow central feathers or bars. A very richly colored and showy variety. Distinct and pleasing. Each, \$1.00. Doz., $\$ 10.00$.

Burlington (1931) - Fine height plant and good size flower. Color a deep velvety, rose red, deeper in lower throat. Lighter in upper throat. A pretty dark rose red. Each, 75c. Doz., $\$ 7.50$.

C. E. Stout (1931) - Fine height and neat plant with five or more large flowers open at a time. Color of richest deep American Beauty rose pink all over the entire flower. Lower petals have much deeper rose red central bars on a deep rose red throat. This is a very distinct and striking flower of great beauty, and I believe destined to become one of the very best for all purposes. Each, \$3.00. Doz., \$30.00.

Chantry (1931) - Fine medium height plant and good size flowers of a deep peach blossom rose pink color. Lower petals have a beautiful pure rose red blotch. All the petals have a fine soft, blush white, narrow border line, beautifully blended. A beautiful variety. Each, $\$ 1.00$. Doz., $\$ 10.00$.

Coming Joy (1931)-Tall, stately plant. Flowers most brilliant orange scarlet. Lower petals have a beautiful deep, orange red blotch with blackish maroon red lines. Beautifully feathered center towards the base terminated by clear white center lines. A very showy and striking flower. Each, \$1.00. Doz., $\$ 10.00$.

Commander Byrd (1931) - Tall stately plant with ample large, beautifully placed flowers open at a time. Color a rich deep salmon red, a little lighter in upper portion of throat. Lower petals have fine deep velvety purplish blotches with beautiful narrow white lines extending towards the points of the petals. A very choice and beautiful variety for all purposes. Each, \$1.00. Doz., \$10.00.

Contrasta (1931) - Fine height plant with plenty of good size flowers open at a time. Color a rich rose. Upper inner throat has bluish cast and lower petals dark velvety blue central bars on deepest rich velvety red ground, covering entire petals. The lower petals are beautifully ruffled while the upper three petals are plain. A very unusual combination and a very pretty red variety. Each, $\$ 1.00$. Doz., $\$ 10.00$.

Cream Cups (1931) - Fine large plant and flower. Color a pure soft creamwhite, delicately blushed over outer 


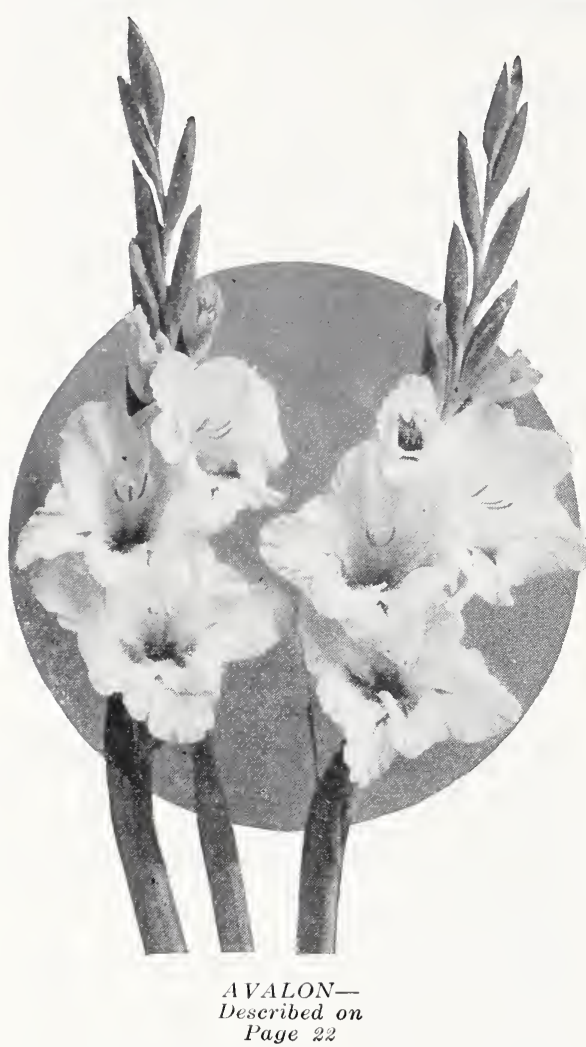

portion of all petals. Throat on lower portion of delicate light canary yellow. All three colors, or tints, so perfectly blended as to give the flower a decidedly rich pastel effect. An exceedingly refined and beautiful flower. Each, $\$ 2.00$. Doz., $\$ 20.00$.

Dainty Lily (1931) - Tall stately plant with six or more large flowers open at a time. Color soft flesh pink flaked deeper on outer portion of all the petals. Throat in lower portion of a rich soft canary or lemon yellow, toning out to a very delicate blushed cream pink toward the ends of petals. A beautiful flower of refined pastel color combination, very pleasing. Each, \$1.00. Doz., $\$ 10.00$.

Dixie Girl (1931) - Good height and fine plant. Color a fiery deep peach blossom rose pink. Large deep rose pink throat with very dark rose red median lines on the lower petals. A brilliant peach blossom rose pink with very beautiful opening buds. Must be seen to realize its beauty. Very extra. Each, \$3.00. Doz., \$30.00.

Dorothy Dick (1931) - Tall fine plant, plenty large flowers open at a time. Color of richest deep salmon red with large clean white throat daintily tinted cream. Extra choice and fine. A beautiful variety in every way. Each, \$2.00. Doz., $\$ 20.00$.

E. T. Barnes (1931) - Tall, strong fine plant. Very large flowers of a beautiful form and perfectly placed. Center of lower petals has a deeper darker red feather. Color a deep rich dark rose red. A very fine showy dark rose red. Distinct and pleasing for all purposes. Each, \$1.00. Doz., \$10.00.

Gloaming (1931) - Fine height plant and large, widely expanded flowers. Color deep Tyrian rose red, lighter on upper central petal and much deeper on most of lower petals. Petals are long pointed and graceful. A fine shade of red and a beautiful flower. Each, 75c. Doz., $\$ 7.50$.

Golden Apricot (1931)-Tall fine plant. Flowers are deep golden fawn yellow on upper petals. Lower petals a deep orange-fawn yellow with finest central lines of orange pink. Petals long, pointed and recurved in most artistic lily-like form a most artistic and beautiful appearance. Very rich color and unusual. Each, 50c. Doz., \$5.00.

H. H. Goldstein (1931) - Tall showy plant with six to eight and more giant flowers open at a time. Color, soft old rose with a tint of blue, lightly flaked rose red and back of flowers dark violet rose red at base. Lower petals have very large orchid or pansy like blotches of deep rose purple blue edged beautifully with creamy blue which again is edged with a faint line of violet rose. A narrow short central line of white still further enhances the striking appearance of this remarkable show and garden variety. A magnificent show variety which cannot be described nor its remarkable appearance realized without seeing it in bloom. Each, \$3.00. Doz., $\$ 30.00$.

Gordon L. Pirie (1931) - Tall stately plant ample and magnificent large flowers. Color as pure a self red as can be imagined of almost the same color as the "President Canna." I do not believe there is another as rich and glowing red glad as this one, and I believe it will create a sensation wherever seen. Each, \$3.00. Doz., $\$ 30.00$.

James M. Sheldon (1931) - Extremely tall plant and foliage and giant wide flowers, spread like a mammoth red butterfly. Color a glowing velvety scarlet with a fine narrow gold bar halfway down lower central petals. Also fine large lower throat blotches delicately mottled with the red and yellow colors combined. Extremely large, stately and showy flowers in every way, and extra grand. One of 
the most wonderful and distinct of all reds. A remarkable flower. Each, $\$ 3.00$. Doz., \$30.00.

J. F. Rosenfield (1931) - Tall graceful plant with six to eight large, widely expanded flowers open at a time and color a blushed cream with lower petals nearly covered a fine shade of canary yellow, outer ends of lower petals same color as upper petals. Buds show a beautiful blending of soft yellow and flesh. Named in honor of my friend, Mr. J. F. Rosenfield, who has originated some of our finest Peonies. Each, \$1.00. Doz., \$10.00.

J. Harry Selz (1931)-Fine tall graceful plant and very large flower. Color bright deep velvety dark maroon red. Lower petals almost covered, much deeper dark red, with only slight white markings near base of throat. A very large and showy variety. Each, $\$ 1.00$. Doz., $\$ 10.00$.

June Night (1931)-Medium height plant with graceful slender spike. Flowers widely expanded with upper central petal well upright form. Upper petals white delicately blushed deeper on back of the flowers. Lower petals across entire petals on inner half of clearest light canary yellow, blending towards the ends to a delicate creamy white. One of those very delicately colored flowers which can only be appreciated by sight. A very delicately colored and beautiful Gladiolus. Each, \$1.00. Doz., $\$ 10.00$.

Lemon Blushes (1931) - Large massive flower of beautiful form and of richest pure self cream color on upper petals. Large soft canary yellow throat on lower petals, with outer ends of same beautiful color as upper petals. Faintest blush of flesh tint on outer borders of all six petals. A very distinct and wonderfully fine blending of softest pastel colors. Each, \$2.00. Doz., \$20.00.

Lewis E. Gary (1931) - Tall stately and showy plant with six to eight and more perfectly placed large flowers open at a time. Unopened buds have a golden flesh tinted color but open flowers are of a very beautiful soft blush tinted cream with lower throat of purest canary yellow. When seen by the late Lewis E. Gary was considered by him the most beautiful among many thousands. Must be well grown to reach its great beauty. Each, \$5.00. Doz., $\$ 50.00$.

Little Red Star (1931) - Tall slender stem. Small gracefully placed upright flowers of fiery deep scarlet self color. A little darker in throat. Stigma and anthers are also upright, giving the flowers a very torch-like and pretty appearance. Each, 50c. Doz., \$5.00.
Louis F. Swift (1931)-Tall fine plant and six to eight large wide open flowers in bloom at a time. Color a striking shade of rose pink faintly tinted lavender and flaked deeper rose. Lower petals, in throat, of richest canary yellow taking on the rose pink blush of the flowers. Outer ends of same rose pink tone as upper petals. A distinct, striking and very beautiful flower in every way. Each, \$2.00. Doz., \$20.00.

Love Song (1931) - Good height plant and large flowers. Upper petals cream, slightly blushed flesh at outer edges. Lower petals light lemon yellow pure self color. A flower which is hard to describe but greatly appreciated when seen at its true worth. A really beautiful and showy flower. Refined and elegant. Each, \$1.00. Doz., \$10.00.

Luxury (1931)-Good height plant and large widely expanded flowers of very striking colors. Upper petals rich canary yellow prettily flushed soft red. Lower petals have most decidedly striking and brilliant red blotches like richest pansies covering most of the petals, with only the outer tips which are of a deep rich lemon yellow. Very beautiful and striking flower. Each, \$2.00. Doz., $\$ 20.00$.

Magnifica (1931)-Tall fine plant and large flowers with plenty open at a time. Color of richest salmon red, delicately flaked toward the outer end of all petals. Lower petals have large beautiful blotches delicately penciled white and orange. These again have a fine central bar of a dark velvety deep orange red. A very harmonious blending of beautiful colors. Very showy and fine. Each, \$2.00. Doz., \$20.00.

Mary Carmichael (1931) - Tall stately plant with six or more large, beautifully placed flowers open at a time. Color of most beautiful deep flesh pink over all petals, tinted faintest lavender rose pink. Inner portion of lower petals blended of most delicate soft creamy yellow. One of the most beautiful and dainty pastel or orchid shades. Impossible to describe. Very beautiful. Each, \$5.00. Doz., \$50.00.

Mischief (1931)-Tall straight plant of good size for an "up," upright flower. Color dark orange red with large dark red throat marks on all petals. One of those new and very unusual "torch lily" types of flower much commented on by all who see them. Each, 50c. Doz., \$5.00.

Mrs. E. A. Hamill (1931) - Tall strong vigorous yellow with six and more large flowers, perfectly placed, open at a time. Color a perfect yellow all over entire flower unmarred by any shade or marking. Far superior to Golden Measure, Gold, or any other 
yellow color and beautiful spikes and flowers. Perhaps as perfect a yellow yellow I have ever seen, in its pure as may ever be sent out. Each, \$3.00. Doz., \$30.00.

Mrs. Geo. W. Hay (1931)-Very tall and stately plant with six to eight or more very beautiful flowers beautifully spaced and perfectly placed, open at a time. Color a pure self lavender rose, a little deeper in upper portion of throat, lower petals have a beautiful narrow feather or central bars of delicate soft rose red. One of the most elegant and best of all. A first class flower in every way for both the florist or in the garden. Each, \$5.00. Doz., \$50.00.

Mrs. John T. Pirie (1931)-Tall stately plant with plenty of very large perfectly placed flowers open at a time. Color on upper side petals beautiful cream blushed daintily on outer portion. Central upper petal faintly blushed delicate lavender with faint lavender thread line on outer edge of petal blending inward on the petal. Lower petals richest soft canary yellow on inner portion taking on the color of upper petals, towards the ends. The whole flower is magnificently beautiful beyond description and truly wonderful. Each, \$3.00. Doz., \$30.00.

Monnie (1931) - Fine showy plant and flowers. Six to eight very dark flowers open at a time. Color intense deepest dark velvety maroon over entire flower. Throat still darker. Lightly ruffled. A very striking and showy "black" of perfect "self" color. Each, \$2.00. Doz., $\$ 20.00$.

Muncie (1931)-Medium tall fine plant with ample blooms open at a time. Color a deep peach blossom pink with a delicate lavender purple cast. Bright rose red on inner half of lower petals. Lighter in inner upper throat portion. A beautiful deep peach blossom colored variety. Each, \$1.00. Doz., \$10.00.

Oracle (1931) - Fine height plant and good size flower, color pure deep rose pink or rose red. Very large pure white throat with faint dainty pink thread lines or veins. A very clean, clear and beautiful white throated red. Each, \$1.00. Doz., \$10.00.

Orchid Flower (1931)-Tall showy plant with six to eight large flowers open at a time. Flowers beautifully and perfectly placed. Color a deep flesh of a very rich orchid tone or color. Inner portion of lower petals a pure soft creamy yellow, outer ends of same beautiful flesh color as the upper petals. A very refined and elegant flower. Among the best and most distinct and beautiful. Each, \$2.00. Doz., \$20.00.

Overture (1931) - Tall neat plant and good sized flowers of roundish form and neatly placed. Color dark rose red. Lighter in upper throat and large dark red throat blotches on lower petals. These have a fine narrow central line of softly subdued white. A rich dark color in this class. Lightly ruffled. Each, \$1.00. Doz., \$10.00.

Peach Blushes (1931)-Neat fine plant with four or more good size flowers open at a time. Color on all petals a beautiful peach blossom pink. Upper throat a little lighter. Lower petals have fine rose pink blotches of pretty form and prettily blended with the main color, which is of the much-admired peach blossom pink. All petals have a blushed lighter border, giving the entire flower a very beautiful effect. A distinct and attractive flower, lightly ruffled. Each, \$1.00. Doz., \$10.00.

Red Mahogany (1931) - Tall slender graceful plant. Flowers medium size and five to seven open at a time. Color intense mahogany deepest brown red over all the petals excepting the throat is of deep blackish red self color. A very richly colored and showy garden flower. Each, 75c. Doz., \$7.50.

Red Torch (1931)-Tall graceful plant and showy flower. Color a deep dark velvety vermilion red. Large lower clear creamy white throat blotches, bordered by a bluish tinted rose. A beautiful garden and showy flower. Distinct and fine. Each, \$1.00. Doz., $\$ 10.00$.

Regal Beauty (1931)_Tall fine graceful plant and large flowers. Color a fine rose pink shaded deeper on outer portion of all petals. Inner portion of petals is a blending of white and soft rose pink, with very large clear canary yellow throat. The flowers are widely expanded, recurved and all the petals are very distinctly waved and curved, giving the flower a very lily-like appearance. A distinct and beautiful form and flower. Each, \$2.00. Doz., $\$ 20.00$.

Rozan Marie (1931)-Tall stately plant with plenty of large showy flowers open at a time. Color a delightful pure rich deep coral pink, or light coral red over entire flower, deepening at outer edges of all the petals which are as beautifully recurved as a lily. Lower petals have deep coral red feathered blotch in finest harmony with entire flower. A distinct and beautiful flower of great beauty, form and general appearance. Each, \$2.00. Doz., \$20.00.

Torpedo (1931)-Another of the new upright type or form. Color dark red with three inner or central petals blotched (neatly) with nearly a black red. Of a most distinct type, a type which no doubt, has a big future when it becomes better known and comes in 
a fine range of color varieties. Each, 50c. Doz., \$5.00.

Western Sunset (1931)-Tall fine plant with plenty medium sized flowers open at a time. Color a dark rich orange red. Deeper on entire lower petals. These again have deep orange central bar or feather, and the edges of petals are a little lighter. A fine bright and showy orange colored variety. Each, $\$ 1.00$. Doz., $\$ 10.00$.

William Randolph Hearst (1931) - Tall showy graceful plant with many large and beautifully placed flowers open at a time. Color deep flesh coral pink over three upper petals, deepening on back of the flowers. Throat on lower petals of richest blushed soft cream canary yellow, deepening toward ends with same flesh pink as the upper petals. No delicately colored rose or any other flower is more beautiful than this wonderful' flower. Was extremely admired by all who saw it in bloom. Named in honor of the great publisher. Each, \$10.09. Doz., \$100.00.

\section{Collection Offers}

\section{PLAIN PETALED IN'TRODUCTIONS}

These Collections Are All Sent with Each Variety Properly Labeled Collection No. 23-All varieties valued up to and including 75c, 7 in all (value $\$ 4.25$ ) for...........\$3.85

Collection No. 24-All varieties valued up to and including $\$ 1.00,26$ in all (value $\$ 23.25$ ) for .... $\$ 19.75$

Collection No. 25-All varieties valued up to and including $\$ 2.00,36$ in all (value $\$ 43.25$ ) for . . . $\$ 36.75$

Collection No. 26-All varieties valued up to and including $\$ 3.00,43$ in all (value $\$ 64.25$ ) for....\$54.60

Collection No. 27-All varieties valued up to and including $\$ 5.00,47$ in all (value $\$ 84.25$ ) for.... $\$ 71.60$

Collection No. 28-Entire collection, one each of the 48 varieties listed (value $\$ 94.25$ ) for...... $\$ 80.10$

Varieties Included in These Collections Are Listed on Pages 31 to 35

D. W. Ryther, Jr., Georgia. "I wish that I might adequately express to you the satisfaction I have experienced from the Gladiolus bulbs purchased from you last Sipring. Such tall healthy plants, such strong spikes and such a range of beautiful color as my small order for twenty-nine bulbs has given me. One of them shooting up two major spikes from the ground, and most of the others having one or two minor spikes jutting out from the main cne. They are certainly a beautiful flower and surprisingly easy to grow. I trust that you will place me on your mailing list for your spring catalog and that $I$ will receive same in time to order a few more bulbs for early planting."

Ir. Ezra Coipitts, Canada. "Last night I received my order of bulblets, $101 / 3$ quarts; quarts of Sulphur Glow, $11 / 3$ quarts of Ventura, 1 quart of Oran, 1 quart of Golden Glory, 1 quart of Avalon, 1 quart of Purple Glory, 1 quart of Rose Glory, 1 quart of Joy and 1 quart of Mary Pickford, and last Thursday received a parcel of Regal Lily seed of 20,000 seed. I counted 1 quart of Sulphur Glow, and if I had 60 bulblets more I would have 4,000 bulblets from one quart. So, make an average, there are about 40,000 in the parcel. If anybody offered me $\$ 100.00$ for them, I would not take it, because I just reckon this parcel is worth ten times the money I paid for them. I have many other of your varieties growing here and next year I expect to order a larger amount from you. I want to get a lot of Lacinatus from you next year if I can. I thank you very much for them, Mr. Kunderd."

Bernard Griffin, Ohio. "I feel that I must write and tell you of the success I had with your bulbs, I only planted a few of your named sorts last spring, but am planning to send for many more this year. The quality, size, variety and coloring of your bulbs have turned me to a Kunderd booster. It must give you pleasure to know that you are making so many of the flower-loving public happy. I only wish I had lots of room so I could send a large order, but by getting a few each year I will soon have a real Kunderd garlen."

W. W. Cannon, Missouri. "I bought about 1200 Gladioli bulbs from you in 1928 and we certainly had some of the most gorgeous bouquets we ever saw. Placed several large baskets on display in down town shop windows and they were admired by hundreds of people. We are in Kansas City quite often, and we visited the different floral shops, but they had nothing that would compare with ours." 


\section{${ }^{36}$ I930 Plain Petaled Introductions}

Like my ruffled introductions of 1930, the "Plain Petaled" varieties have also enjoyed wide popularity. These large, magnificent Gladioli are the result of fifty years of scientific breeding and development. They have reached the highest standard of perfection. The colors are marvelous and their forms are most unusual. These are typical Kunderd beauties priced within the reach of all. Be first in your neighborhood to have these new introductions.

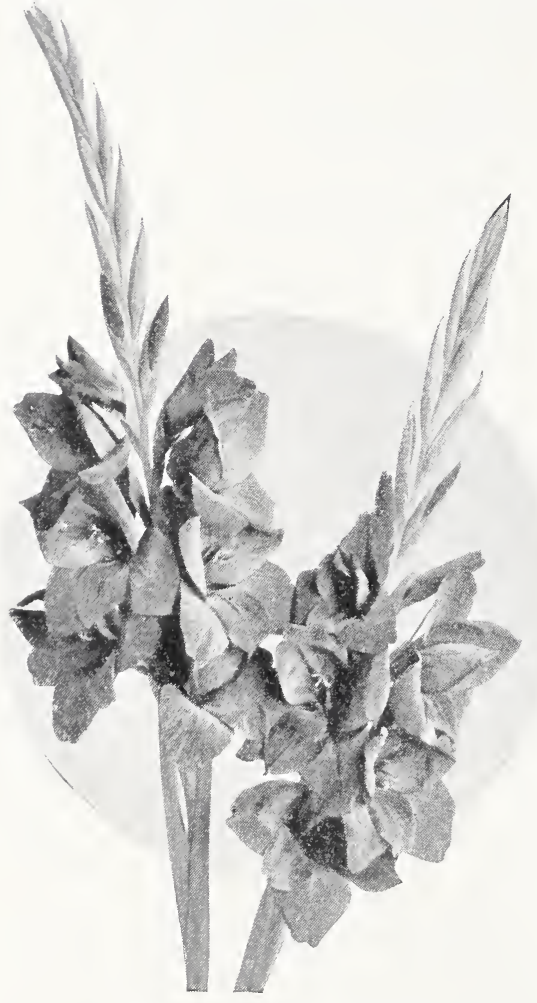

RAJAH-Described on Page 68

Anne Nielsen (1930. 81 days.) - A fine height plant with a giant flower. Petals broad, long pointed and recurved. Color of brightest, rich deep shrimp pink, lighter towards the throat. Large light creamy white throat on lower petals deepening to richest soft clear canary yellow on inner half of the petals. Reminds of "Pauline Kunderd," equally fine, but different shade and color. Very showy and fine. Each, $\$ 2.00$. Doz., \$20.00.

A. R. Cole (1930. 90 days.) - Tall graceful plant with five or more beautiful flowers open at a time. A delicate almost pure white with beautiful blush of pure light pink on outer edges of all six petals. Only faintest cream tone in lower throat, sometimes a little blushed. An elegant, refined, and beautiful flower. Each, 75c. Doz., \$7.50.

Arthur Cowee (1930. 73 days.) - Good height and fine plant. Flowers quite large and five to six open at a time. Color of richest deep clear salmon red. Outer one-half portion of lower petals of same color. Inner portion of glowing fiery salmon red, beautifully feathered with fine alternating lines of beautiful dark red and central bars on a clear white feathered throat. A magnificent flower. Each, \$3.00. Doz., $\$ 30.00$.

Babylon (1930. 70 days.)-Fine medium height to tall plant and large flowers. Color a beautiful deep clear cardinal red all over, excepting narrow dark red median lines on lower petals, extending into the base of the throat. Just the color of "Gov. Hanly," in artificial light, but a little darker in day light (out of doors). Also considerably larger, more massive and showy and much later in season of flowering. A truly magnificent red. Each, 75c. Doz., $\$ 7.50$.

Black Feather (1930. 80 days.) - Tall and showy plant, with six or more good sized flowers, for an upright, open at a time. Color a very dark deep rose red, with throat of an almost black extending clear to the base. This is a very excellent upright flowering variety, in a dark color. Occasionally a forward facing bloom appears on some spikes. A group of this new form is very torch-like in appearance and very attractive. Each, 75c. Doz., \$7.50.

Blushes (1930. 74 days.)-Medium tall fine plant with five or more quite large flowers open at a time. Flowers nicely spaced and widely open. Color almost a white, blushed cream and blushed pink a little deeper towards the outer ends of the petals. Slight, pale pink, narrow pencil lines on mid ribs of lower central petals. Especially fine in artificial light. Each, \$1.00. Doz., $\$ 10.00$. 
Break O'Dawn (1930. 83 days.)-Very tall and stately plant. Large flowers and 5 to 7 or more open at a time. Flowers in upper petals deeply blushed white, becoming deep apple blossom pink or rose towards the ends. Inner, portion of lower petals have a decidedly deeper rose pink color with very rich dark red central bars. An altogether exquisite and beautiful flower which I believe will become very popular. Each, $\$ 1.00$. Doz., $\$ 10.00$.

Bright Spots (1930. 74 days.)-Very tall and showy plant, 6 and more large flowers open at a time. Color a light rose red. Lower petals have very large Gloxinia like throats of very dark velvety maroon red bordered and stippled creamy white. This type usually has distinct smaller blotches or "eyes" on either or both sides of upper petals. A favorite type with the French Gladiolus Specialists. (Another very beautiful kind of this type is the variety “Emblem.”) Each, 75c. Doz., \$7.50.

Brilliant Sun (1930. 86 days.)-Medium tall plant with large brilliant red purple flowers with a very dark purple red lower throat. The color and shade of it are among the most admired and popular. My collection of gladioli contains a number similarly colored varieties, but all of them which I catalog are distinctly different. All are extra fine in artificial light. Each, \$1.00. Doz., $\$ 10.00$.

Burning Bush (1930. 92 days.) - Tall, stately and fine plant. Large flowers of deepest fiery salmon rose red. A little deeper red in lower throat. A white narrow line extends from the throat featherings outwardly, well towards the ends of lower petals, giving a very distinct appearance. Of richest bright salmon red color. Very showy and a fine variety. Each, \$1.00. Doz., $\$ 10.00$.

Capt. B. B. Lipsner (1930. 75 days.)Fine height plant and showy flowers. Flowers good size and very bright fiery rose pink much lighter in upper throat and much deeper on ends of petals and still deeper on lower petals. Inner half of lower petals have beautiful deep rose red throat blotches edged a lighter rose, sometimes edged a very delicate soft tone of cream. A very unusual and showy variety. Each, $\$ 1.00$. Doz., $\$ 10.00$.
Cheerio (1930. 98 days.) - Medium tall fine plant and quite large flowers of richest salmon red. Throat of brightest orange red deeper in the centers. Lower petals especially large, giving the flowers a widely opened and rounded form. A very showy, distinct and beautiful variety. Each $\$ 1.00$. Doz., $\$ 10.00$.

Clarise (1930. 77 days.)-Tall graceful plant with giant flowers. Purest deep flesh or salmon pink over entire flower excepting inner portion of lower petals which is a soft creamy yellow overlaid with very faint pencilings and tracings of delicate salmon pink. Extraordinary showy and beautiful appearance. Refined and delicate coloring. Extra grand. Each, \$3.00. Doz., \$30.00.

Claude Bowers (1930. 96 days.)-Medium tall fine plant. Large beautifully placed flowers and 6-8 or more open at a time. Color of most beautiful pure rose red, a little deeper on lower petals with almost no throat markings, giving an almost perfect self-color effect. The inner upper throat is much lighter rose pink giving a remarkable effect from a straight front view, or when tilted a little backwards. The flower tilted forwards at an angle of $45^{\circ}$ is of a perfect self-color, unsurpassed in color by any red rose. Very, very beautiful and distinct. Each, $\$ 2.00$. Doz., $\$ 20.00$.

Color Beauty (1930. 83 days.) - Tall, graceful plant with eight or more medium sized flowers open at a time. Color deep Tyrian rose red flaked deeper. Outer portion of lower petals intense fiery velvety dark rose red. Upper throat much lighter. Base of throat feathered beautifully and penciled tyrian rose on a white ground. Central bars of velvety tyrian red-an all around beautiful and showy variety of most elegant and beautiful appearance. Exceedingly rich, showy and striking color. May fairly be called a color beauty. Each, $\$ 2.00$. Doz., $\$ 20.00$.

Cream Puff (1930. 84 days.) -Fine plant of medium height with five or more very shapely large flowers open at a time and facing very beautifully. Color upper petals a delicate creamy buff. Lower petals have a large distinct and vivid blotch of deep red, bordered finely by a deep golden buff, extending well out on the petals, shading to a lighter tone towards the petals' ends, 


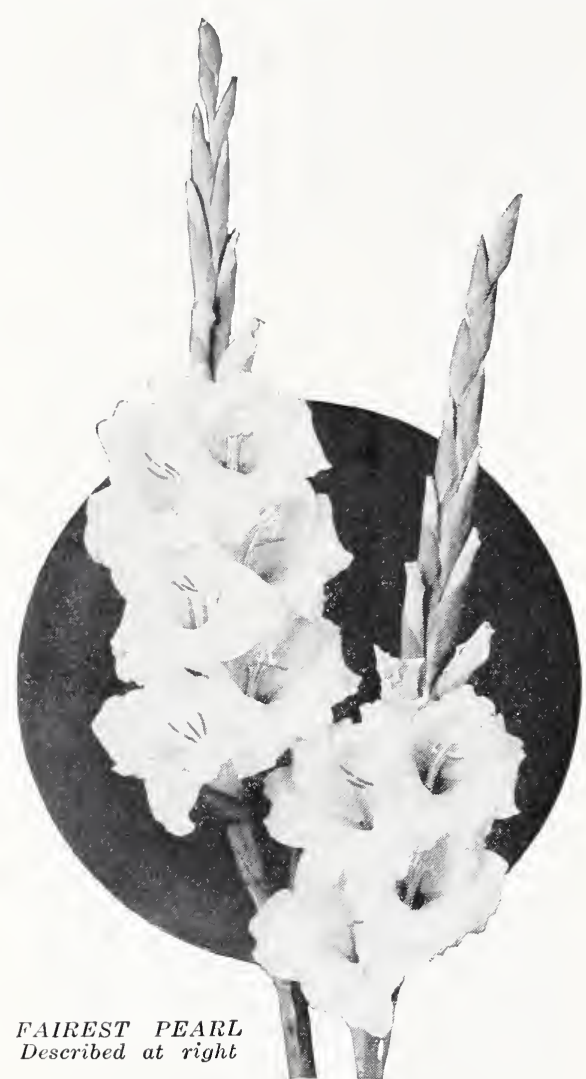

very striking and showy. Each, \$1.00. Doz., \$10.00.

Darling O'Mine (1930. 81 days.) - Fine height and shapely plant. Large flowers widely expanded and perfectly placed. Color delicate salmon pink, deepening towards the ends of the petals. Lower petals have large throat blotches of deep red in the center lightening to a glowing orange red. A distinct and most remarkably beautifu! variety. Each, \$2.00. Doz., \$20.00.

Delafern (1930. 93 days.) - Elegant plant, medium tall. Color a blushed pink over cream. Softest pale yellow on lower petals, pinkest blushed towards ends of petals. Upper petals considerably deeper pink than on inner of throat portion, giving an attractive appearance. The whole effect is very delicate, refined and charming. Each, $\$ 1.00$. Doz., $\$ 10.00$.

Dew of Heaven (1930. 96 days.) - Very tall and stately plant. Flowers large and showy. Color of a rich deep rose pink with a tyrian rose tone which is hard to describe. Throat has a beautiful tyrian rose red blotch with fine central bars of white dividing the same giving a beautiful effect. An elegant and distinct variety. Each, \$1.00. Doz., $\$ 10.00$.

Evening Glow (1930. 77 days.) - Tall strong vigorous plant with large massive flowers. 5 to 7 or more, open at a time. Color very dark cardinal maroon red all over, excepting a deeper flaking around entire flower and lower petals have a much darker throat which in turn has beautiful narrow white lines extending one-half way the length of the petals. A very showy and distinct variety, richly colored. Each, $\$ 1.00$. Doz., \$10.00.

Fairest Pearl (1930. 103 days.)-Medium tall, strong elegant plant with six or more large blooms open at a time. A beautiful white of a delicate creamy tint and faintest soft yellow on lower petals, almost white, and no flaking nor other markings. Splendid substance and of ideal form. Perfect placement. An extra choice tinted white. Illustrated on this page. Each, $\$ 3.00$. Doz., \$30.00.

Fiancee (1930. 83 days.) - Fairly tall medium-sized flowers. Six and more open at a time and exceedingly striking and showy. Color a creamy white with an exceedingly large and very beautiful deep velvety red blotch covering most of the lower petals. The center of these blotches is a little lighter red finely blended with the deeper dark red edges of the blotches. Perhaps no richer blotched variety in existence. Each, \$1.00. Doz., \$10.00.

For You (1930. 79 days.)-Medium tall, fine plant. Five or more flowers open at a time. Color of upper petals a rich orange rose red, flaked deep red. Lower petals entirely covered richest fiery velvet red. Finely feathered white at base of throat and a faintly subdued, small white short line of pale white in middle of the blotches. Medium sized flowers. Fine appearance and very showy. Each, \$1.00. Doz., $\$ 10.00$.

Gay Feather (1930. 74 days.)-Tall fine plant, very striking and showy flower, deep rose vermilion. Lower petals have deeper and beautifully feathered darker red blotches of very neat bird-like appearance. These bird-like blotches have a darker red median line, or body extending towards the throat on a soft rosy pink ground, and the outward ends of the bars, or tails of the birds, are white and extend towards the tips 
of the petals. Nothing more beautiful in a richly colored Gladiolus. Each, $\$ 1.00$. Doz., \$10.00.

Glenn Banks (1930. 98 days.)-Medium tall and fine plant with 5 or more large shapely flowers open at a time. Color dark red purple with throat very much deeper, of very dark, velvety rose red, extending almost to the ends of petals. The center has darker red narrow median lines which sometimes have a slight narrow white central line. A very beautiful dark red Gladiolus. Each, 75c. Doz., \$7.50.

Golden Rose (1930. 88 days.) - Tall stately plant and a large showy flower of delicate old rose color flaked deeper rose on outer portion. Throat very beautifully feathered pink on a large widely deep canary yellow base. A fine deeper yellow median line extends almost out to ends of lower petals. A very distinct Gladiolus. Each, 75c. Doz., \$7.50.

Gov. Emmerson (1930. 68 days.)-Tall strong plant and massive flower of a deep vermilion orange, flaked faintly with a deep orange red. Outer ends of lower petals a deeper shade of same color, but the lower throat is entirely covered by pure deep dark rose red. An outstanding beauty, very showy and massive. Each, \$2.00. Doz., \$20.00.

Graf Zeppelin (1930. 73 days.)-Extra tall and stately plant with many large widely expanded blooms open at a time. Flowers are uniformly and perfectly placed on the spike. Large round flowers with extra strong lower petal development. Color of fine pure soft rose pink, deepening towards outer ends of all six petals. Lighter soft rose pink towards inner portion. Lower petals have a delicate light rose red inner throat marking extending outwards to a delicate white. Each, \$3.00. Doz., \$30.00.

Happy Heart (1930. 79 days.) - Good height and fine plant with 5 or more good sized flowers of a very beautiful shade of red open at a time. Upper throat nearly white. Lower petals, inner portion, nearly covered with deep velvety dark red. A very rich, showy and beautiful red. Each, $\$ 1.00$. Doz., $\$ 10.00$.
Haughty (1930. 80 days.)-Medium tall, fine plant. Flowers very large and massive. Color rich deep rose red. A little deeper on outer edges of the petals, but so subdued in tone as to be almost unnoticeable, might almost be termed a self-color. Magnificent and beautiful. Each, 75c. Doz., \$7.50.

Helen Keller (1930. 79 days.)-Medium tall fine plant. Five or more large flowers open at a time. Color a clear rose pink, moderately flaked deep orange rose towards outer edges of the petals. Lower petals have large wide beautifully feathered soft rose red blotches. Beautiful opening buds. Charmingly effective and pleasing flower. Each, \$2.00. Doz., \$20.00.

H. H. Groff (1930. 67 days.)-Tall showy plant with 6 or more perfectly placed flowers of magnificent purest deep self salmon red color. Lower petals same color with beautifully feathered lavender white on inner portion. I consider this variety unsurpassed in any

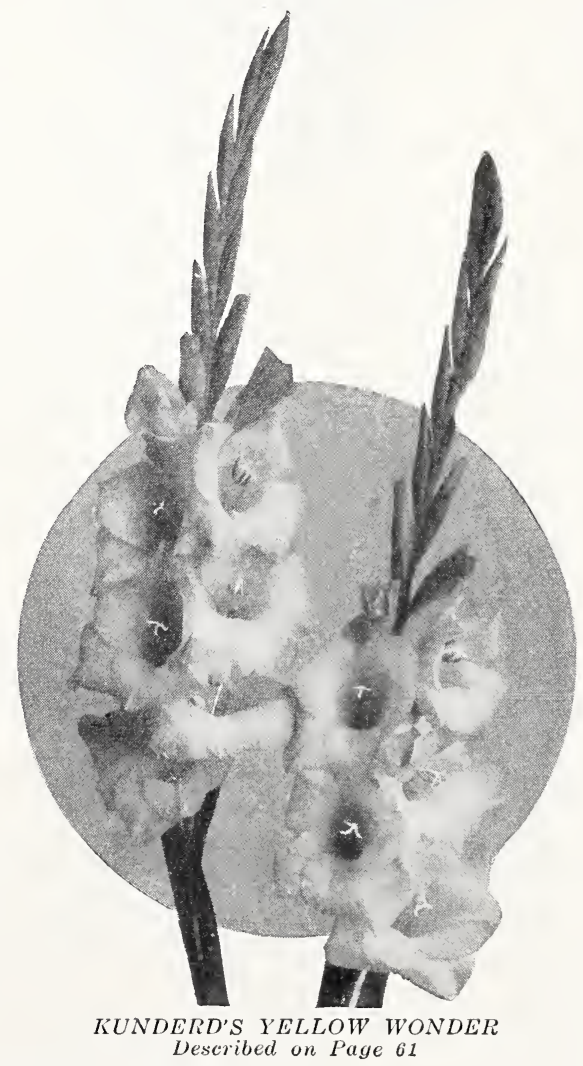




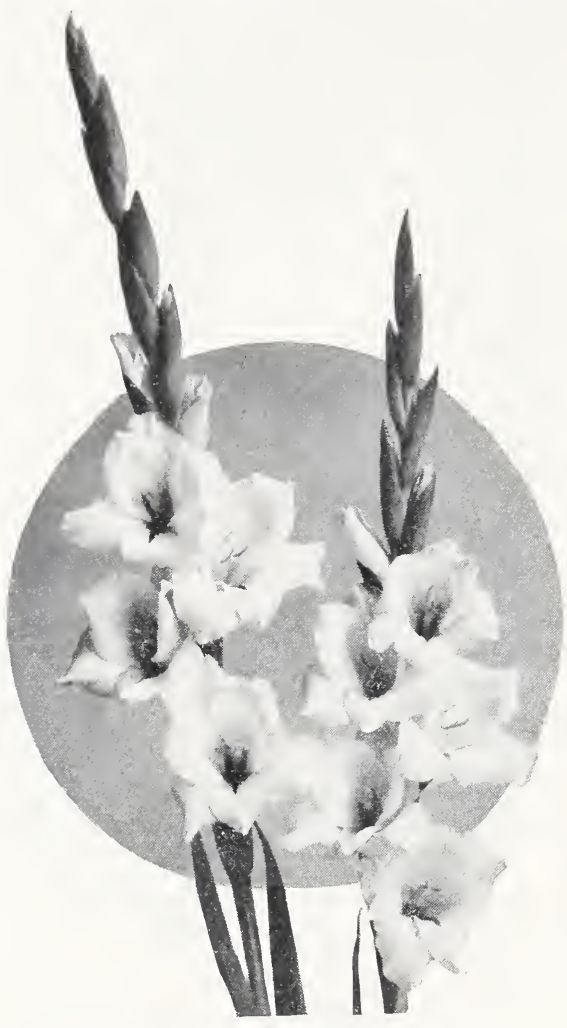

PANTHEON-Described on Page 65

color and have named it in honor of Mr. H. H. Groff of Canada, to whom the Gladiolus world owes a great debt of gratitude. Each, \$3.00. Doz., \$30.00.

Holy Grail (1930. 83 days.) - Very tall plant with elegant foliage and flowers usually cupped and upright. Color almost same as the famous variety "America" only a little more lavender tinted. Lower petal, usually only one, also has the marking of "America" edged at ends a delicate cream. Very unusual. Large flowers and stately spike and six or more flowers open at a time. Each, \$1.00. Doz., \$10.00.

Hugo Eckener (1930. 88 days.)-Very tall plant and very large and massive flower, beautifully formed and perfectly placed on the spike. Color a bright blood red, a little lighter in upper portion of throat. Lower portion of throat deeper blood red down center of petals with full width of petals a wide fiery orange vermilion. A magnificent and gorgeous flower. Each, $\$ 2.00$. Doz., $\$ 20.00$.

June Moth (1930. 88 days.) —Fine height plant with broadly expanded wide open flowers of Nanceianus or Butterfly form. Color, rose red on upper petals and ends of lower ones. Lower petals have very large dark rose red blotches the full width, extending well towards outer ends. The outer ends of the lower petals for a little over onefourth of an inch are of same color as the upper petals. A fine and showy variety. Each, $75 \mathrm{c}$. Doz., $\$ 7.50$.

Leopard (1930. 72 days.) - Graceful plant and a very neat and graceful flower. Ground color a fine tone of rose pink with short flakings or spots so uniformly distributed as to suggest its name. The spots are a beautiful deep rose red. The throat is a large, clear white, lightly flushed pink towards the base and outer portion of blotches is clear delicate soft creamy yellow delicately blended. An altogether distinct and very pretty flower. Each, \$2.00. Doz., \$20.00.

Mahogany (1930. 91 days.) - Tall stately plant with 5 or more large flowers open at a time. Ground color of self deep mahogany red. Large throat of beautiful clear, but dark red elegantly stippled on a white ground. Edges of throat blotches have a wide border of a glowing bright deep red. An elegant show and garden variety. Each, \$1.00. Doz., \$10.00.

Melody Maid (1930. 70 days.) - Very slender, graceful, medium height plant with 5 to 7 or more medium sized flowers open at a time. Flowers graceful and airily poised and of most decided pure self flesh color, excepting a long, wide beautiful red feather on lower petals. Back of stems and buds also of a fine flesh pink color. Foliage very unusual, and elegantly drooping, the lower ones falling in graceful arches to the ground. One of the refined and dainty things hard to describe and must be seen to be appreciated. Each, $\$ 2.00$. Doz., $\$ 20.00$.

Me Too (1930. 83 days.)-Tall stately plant and spike with 6-8 or more perfectly placed flowers open at a time. Color intense, dark maroon over entire flower, excepting large blackish maroon covering inner two-thirds of lower petals. The central one-third of the width of the blotches is of a much lighter red. elegantly blended with the blackish edges of the blotches. An extremely striking, rich and showy flower. Each, \$2.00. Doz., \$20.00.

Nidway (1930. 87 days.)-Fine height plant and extra large flowers of purest deep salmon pink. Lower petals have a large soft yellow throat magnificent- 
ly feathered and penciled deep salmon red. Throat is still further beautified by a narrow deeper red barred median line. An extra showy and beautiful flower in every way. Each, $\$ 1.00$. Doz., $\$ 10.00$.

Miss Springfield (1930. 69 days.)-Tall stately plant with many medium size flowers open at a time. Most of the buds show color when first half dozen blossoms are open, giving a long beautiful spike effect. Color deep tyrian rose red, deeper on lower petals. Upper throat much lighter and all 6 petals have a beautifully subdued bar of white. A handsome showy spike and a pretty flower. Each, \$1.00. Doz., $\$ 10.00$.

Mrs. A. R. Erskine (1930. 70 days.)Fine height plant with six to eight large flowers open at a time. Upper petals fine tint of pure flesh color. Lower inner petals of richest canary yellow perfectly blended with the main color. One of my finest for color blending. Each, \$2.00. Doz., \$20.00.

Modern Beauty (1930. 82 days.-Tall fine plant and large flowers. Color white deeply blushed a soft lavender rose pink. Somewhat deeper on inner upper and the lower petals. Throat on lower petals has large clear creamy blotches edged deeper pink and with a narrow slight pencil line on midrib. An extra showy and fine florists' variety. Very choice. Each, \$2.00. Doz., $\$ 20.00$.

Mrs. Sam Spohn (1930. 85 days.)-Fine plant and large flowers of richest deep clear rose pink. All six petals have a very fine silvery white border nearly one-eighth inch wide, be a u if u lly blended. Lower petals have large blotches almost like "Mrs. Frank Pendelton." These again have subdued creamy white margins. The whole effect is unusually beautiful. More flowers open at a time than "Mrs. Frank Pendleton" and nearly as large. Each, $\$ 2.00$. Doz., \$20.00.

Iottled Feather (1930. 80 days.)-Medium height plant of very neat appearance. Average of five fair sized flowers open at a time. Color, deep orange alternating with orange vermilion fiaking. Central bars on petals usually all six white, with all white narrow thread line of white on the lower ones. Throat has a delicately subdued marking of faint rose-pink. An extremely rich colored fancy variety of great beauty. Each, \$1.00. Doz., \$10.00.

Mountain View (1930. 77 days.)-Medium height plant with five or more very pretty blooms open at a time. Color of all six petals a beautiful white, blushed fine rose pink, deeper on inner upper throat. Lower petals have unusually striking and attractive large deep velvety red blotches on a white ground, daintily cream bordered. An unusually striking and attractive flower. In fair supply. Each, 75c. Doz., \$7.50.

My Self (1930. 97 days.)-Medium tall, strong plant and good sized flowers. Seven and more open at a time. Color, fine distinct rose, almost self color. Attractive and a pleasing flower. Back of flower also very showy. Each, 75c. Doz., $\$ 7.50$.

Nightingale (1930. 72 days.)-A good height plant and fine size flower. Color pure clear rose pink with a strong lavender purple tone on all six petals, excepting a large clear throat of a fine soft golden yellow, bordered with white at outer border. Unusual and fine color combination. Each, $\$ \mathbf{1 0 0}$. Doz., $\$ 10.00$.

Northern Light (1930. 97 days.)-Medium height with five or more very large blooms open at a time. Lower

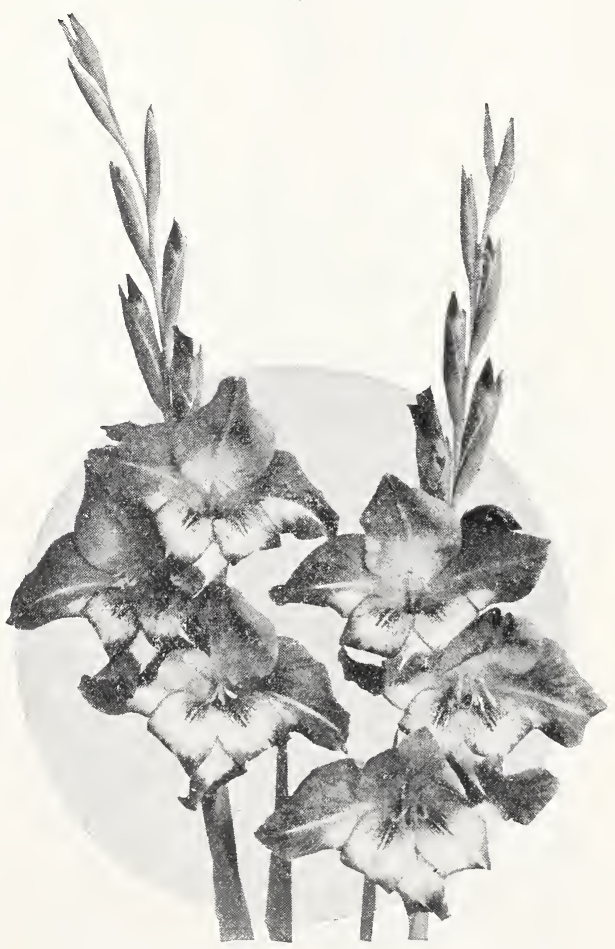

SHOW FLOWER-Described on Page 70 


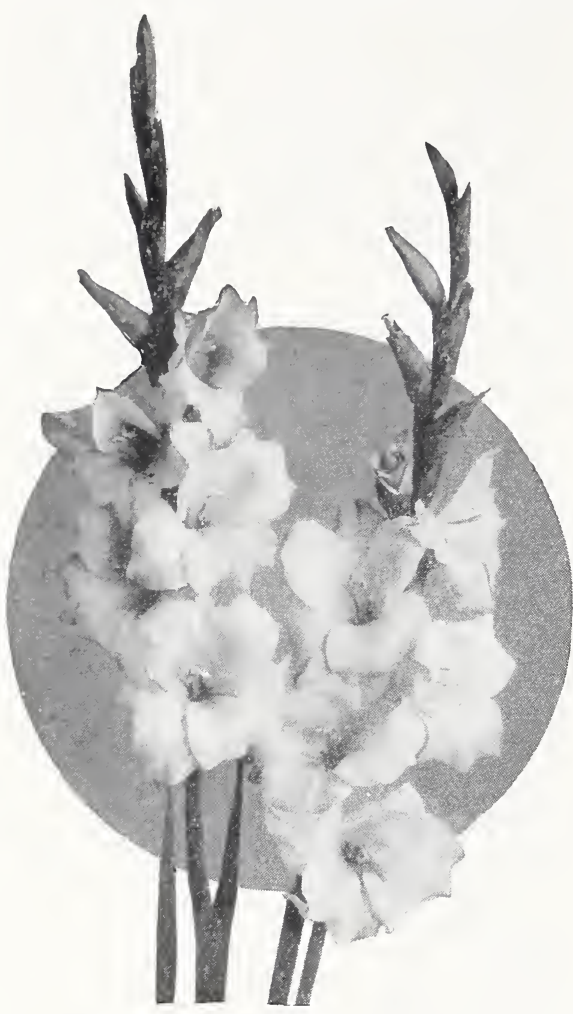

MRS. DR. NORTON-Described on Page 63

petals and ends of upper a fine rose pink. Upper throat almost white, only faintly blushed. Lower throat a little darker than the darker portion of the petals. Back of flowers as beautiful as the face. Unusually colored and extremely fine. Each, \$2.00. Doz., $\$ 20.00$.

Odyssee (1930. 80 days.)-Good height and massive plant with seven and more large massive blooms open at a time. Flowers round in form with very wide round formed petals of strong substance. Color of finest white, very faintly blushed rose pink, slightly deeper towards the ends of all the petals. Fine throat blotches of pure soft rose red with deeper rose red central bars, the effect is much like a beautiful humming bird form with wide wings, and flying down the throat of the flower. Beautiful and showy flower. Each, \$1.00. Doz., $\$ 10.00$.

Opal Fringe (1930. 85 days.)-Medium tall plant with 6-8 and more flowers open at a time. Color, deep orange salmon with very large dark velvety maroon red blotches on lower petals. Lightly and softly stippled a creamy white at edges of the blotches. A showy flower in the garden and for decorative effect. Each, 75c. Doz., $\$ 7.50$.

Orangine (1930. 79 days.) - Medium height and neat plant. Flowers of good size and distinct rich orange color. 'Throat very much like in "Alice Tiplady," but more delicate and subdued on delicate orange yellow-ground. As fine as "Alice Tiplady," but of true orange color. Fine in every way. Each, 75c. Doz., \$7.50.

Peach Bud (1930. 77 days.)-Tall, graceful plant with six to eight nice size and very perfectly spaced flowers, uniformly placed, open at a time. Color a clear and wonderful shade of deep rose pink. Throat lighter in upper portion and has a magnificent blotch of richest rose red on lower petals. One of the richest and purest colors yet produced. Each, \$1.00. Doz., $\$ 10.00$.

Peach Glow (1930. 110 days.)-Medium height and graceful plant. Flowers large and very graceful form. Color deep peach blossom, flaked deep rose pink. Throat a little deeper, rose pink. Opening buds very elegant. Of ruffled form, somewhat upright, and as in the ruffled Gladioli a far more beautiful opening bud than are the buds of the plain petaled varieties. A very fine variety. Each, \$1.00. Doz., \$10.00.

Peacock (1930. 82 days.)-Medium tall and fine plant, with good sized flowers. Color a light rose pink with striking and large showy blotches which show clearly in five color tones beside the basic or ground color of rose pink. Upper petals show the "eyes" clear across the petals near the outer ends. Another "Gloxinia" like variety, rich and showy. Each, \$1.00. Doz., \$10.00.

Pal O'Mine (1930. 75 days.) - Good height plant and large flowers, six and more open at a time facing perfectly. Color, deep purple rose, flaked dark purple on upper petals, deeper at edges. Throat, upper portion much lighter. Lower petals entirely covered deep velvety red purple, deeper towards the center, but lightening towards the base of the throat. A clear narrow line of golden yellow extends clear around all of the lower petals giving the flowers a very unique and beautiful effect. Each, \$1.00. Doz., \$10.00.

Pansy Flower (1930. 75 days.) - A nice plant with good sized flowers of light 
shade of old rose pink. A little deeper on outside of the flowers and on ends of lower petals. Throat has deep velvety rose red pansy like blotches, elegantly feathered creamy yellow and pink at edges. A neat, distinct and pretty flower. Each, 75c. Doz., \$7.50.

Petrella (1930. 81 days.)-Tall fine plant with a long spray of flowers open at a time. Flower of good size, white with a faint lavender blush evenly distributed over entire bloom. Neatly penciled and lightly feathered center of lower petals. A pretty spike and an attractive flower. Each, 75c. Doz., $\$ 7.50$.

Pink Clover (1930. 94 days.)-Tall fine plant and with six or more large flowers open at a time. Color, rose pink, tinted slightly lavender and deeper on lower petals. Upper, inner throat blended from the edges to an almost white, giving the flowers a very unusual and striking appearance. Very showy. A distinct and beautiful variety. Each, 75e. Doz., \$7.50.

Pink Favorite (1930. 102 days.)-Medium tall plant with six or more large showy blooms open at a time, all perfectly placed and color uniformly rose pink all over, excepting a fine deep rose red median line in throat. Appearance of fine self color rose pink. A splendid variety. Each, 75c. Doz., $\$ 7.50$.

Pink Lady (1930. 83 days.)-Medium tall, elegant plant with five or more quite large and widely expanded flowers open at a time. Lower petals relatively quite large. Color a whitish cream, faintly blushed bright pink around the entire flower. Throat has a very elegant delicately feathered pink on a delicate yellow background which is also very daintily blushed pink. Extra fine in artificial light. Each, \$1.00. Doz., \$10.00.

Prince Charming (1930. 71 days.)-Tall graceful plant with many good sized gracefully poised and elegantly spaced flowers open at a time. Upper central petal orange rose red. Almost all of three lower petals and most of two main side petals covered with pure self canary yellow excepting ends of petals are same color as the upper central one. A very neat and charming flower of unusual and attractive appearance. Each, \$1.00. Doz., \$10.00.

Promise (1930. 76 days.) Tall, stately plant with eight and more quite large and very showy flowers open at a time. Ground color a clear, clean blushed white, very beautifully flaked a deep rose pink on all the petals. Throat daintily feathered pink on pure clean white ground. This flower is very much the color of the famous "America." Each, \$1.00. Doz., \$10.00.

Proud Lily (1930. 85 days.) - An upright variety, tall stately plant with six and more large flowers open at a time. Color, deep purple-red all over with an intense blackish purple red throat extending clear down to base. I believe this type of gladioli will become very popular for decorative purposes soon as a wider range of beautiful color shades can be produced This is an outstanding variety of this recent form. Each, $\$ 1.00$. Doz., \$10.00.

Proud Feather (1930. 95 days.)-Tall, slender, graceful plant. Flower fine and shapely, of good size and airily placed. Color in upper portion a deep salmon or shrimp pink, lower portion also a little lighter on outer edges of petals becoming still lighter towards the base of throat, deepening again in

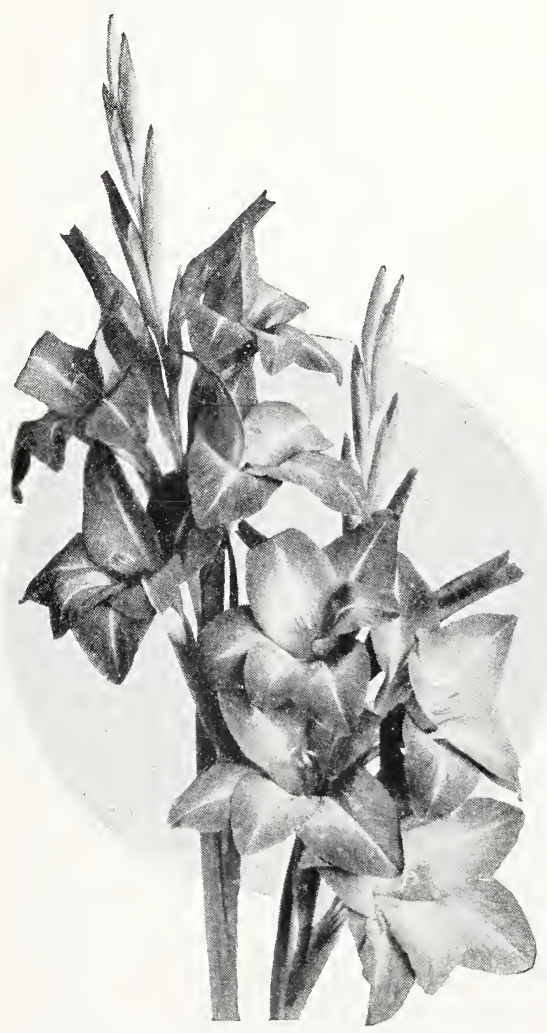

ORANGE PLUME-Described on Page 64

A. E. Kunderd, Goshen, Indiana 


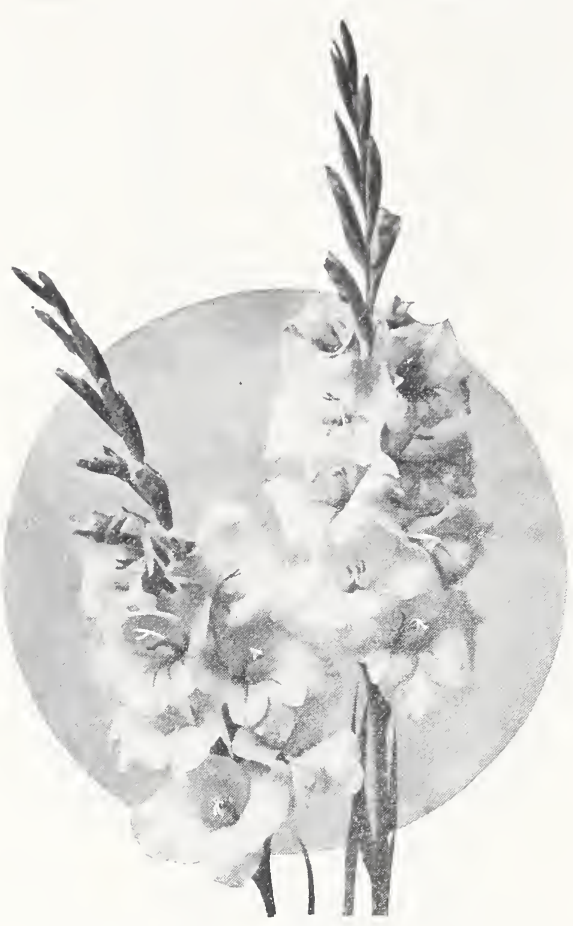

BYRON L. SMITH-Described on Page 50

base of throat. Very distinct and unusual coloring and very delicate and refined. Each, 75c. Doz., \$7.50.

Purple Beauty (1930. 97 days.)-Medium height plant and good size flowers of a deep purple violet. Throat has blotches as large as "Pendleton" clear to base of flowers, bordered at outer portion as subdued white. A conspicuous and richly colored variety. Each, 50c. Doz., \$5.00.

Purple Crown (1930. 94 days.)-Tall, stately plant. Six or more good sized flowers open at a time. Color dark velvety purple, darker on lower petals and darkening towards the base of throat. A short narrow bar of subdued white extends from the dark purple blotches on the lower petals lightening up the whole flower very effectively. A distinct and showy flower of very rich coloring. Each, \$1.00. Doz., $\$ 10.00$.

Purple Feather (1930. 84 days.)-Neat medium tall plant, five and more medium sized flowers neatly placed, open at a time. Color rose purple. Throat in inner portion a deep rose purple. The outer half of the lower petals has large white blotches of pure white full width of the petals, bordering the deep purple inner throat, making a conspicuous and showy flower. Each, 75c. Doz., $\$ 7.50$.

Red Beauty (1930. 96 days.)-Neat height plant with five or more fine and shapely medium sized flowers open at a time. Color a very rich bright deep velvety red, flaked much deeper at the edges of the petals. Lower inside petals very rich darker red and have slight median line of white extending over outer half of throat, about half towards the end of the petals. A very rich and beautiful deep red variety. Each, 50c. Doz., \$5.00.

Red Rock (1930. 83 days.)-Of good height and a strong, vigorous plant. Flowers very large and massive. Color deep blood red, deeper over entire lower petals. Lower petals also have fine narrow very dark velvety red central bar. The whole effect is a rich "self" colored deep red of magnificent and showy appearance. Each, $\$ 1.00$. Doz., $\$ 10.00$.

Red Rose (1930. 86 days.)-Fine plant and large flower. A pure red rose, a little deeper rose red on lower petals. Slightly darker median line extends down the lower portion of the throat, enhancing the beauty of this flower still farther. Each, \$2.00. Doz., \$20.00.

Rolling Prairie (1930. 105 days.)-Tall fine plant with beautiful deep rose pink flowers, flaked slightly a little deeper. Lower throat has a large showy, beautifully blended deeper rose throat with slight faint narrow median line on midrib. Back of lower petal has a creamy white ribbon showing on the outside of the petals, giving a very pleasing and unique effect. A refined and rich flower. Each, \$1.00. Doz., $\$ 10.00$.

Rose Ann (1930. 108 days.)-Tall strong plant and grand flower. Color rose salmon with finely feathered lower center and a beautiful deep red central bar. A gorgeous and showy variety. Truly magnificent and must be seen to be appreciated. Each, $\$ 2.00$. Doz., $\$ 20.00$.

Rose Feather (1930. 84 days.)-Fine height plant and good sized blooms of soft rose pink, tinted old rose, and elegantly flaked deeper rose. Throat a deeper pink, or light rose red with deeper red median line, or central bar on lower petals. A pretty plant and flower. Each, 75c. Doz., \$7.50.

Rose Pendleton (1930. 89 days.)-Medium tall, fine plant. Flowers not 
quite so large as "Pendleton," but reminds one much of that great variety. Color deep rose pink with much darker rose red blotch than in the "Pendleton" and of glowing velvety dark red. A uniform even self colored variety, except the very striking blotches. Each, 75c. Doz., \$7.50.

Rose Splendor (1930. 91 days.)-Fine size plant and large flowers, six and more open at a time. Color a fine self rose pink over all six petals, each having a clear sixteenth inch white border around all of the petals. Pronounced dark rose red throat. The back of the flower is the same beautiful rose pink with the narrow white border of the petals charmingly enhancing the beauty of this flower. Distinct. Each, $\$ 1.00$. Doz., $\$ 10.00$.

Royal Beauty (1930. 74 days.)-Tall, stately plant with five or more large perfect flowers open at a time. Color a very rich deep purple red. Large and very beautiful deep velvety dark purple red throat which greatly enhances the beauty of this flower. Each, $\$ 1.00$. Doz., $\$ 10.00$.

Salmon Fins (1930. 66 days.) - Strong medium size plant with a giant full rounded beautiful flower of most glowing deep bright salmon rose flowers. Lighter in upper portion of throat and a deep orange red over all of the lower petals. Center of lower petals have deep red central bars enhancing still further an already exceptional striking and showy variety. Each, $\$ 2.00$. Doz., $\$ 20.00$.

Sammy Lane (1930. 84 days.) -Flowers large and five or more open at a time. Color a light flesh pink. Lower petals on inner portion are a beautiful white with four narrow rose colored pencil lines alternating with three white nărrow pencil lines extending half the length of the petals. Opening buds show a deep and very beautiful shade of deep shrimp pink giving open flowers a greater charm and beauty. Each, 75c. Doz., \$7.50.

Senator Beveridge (1930. 103 days.)Tall, extra fine plant with medium large and very perfect flowers. Color, pure light blood red, feathered very delicately a little deeper red on throat of lower petals. From these throat feathers an almost imperceptible narrow thread line extends about onefourth of the petals' length. A more beautiful and elegant red is hard to imagine, and the flowers are extremely rich and showy in artificial light as well as in the garden. As fine as the finest. Each, \$2.00. Doz., \$20.00.
Serene (1930. 87 days.)-Extra tall plant with plenty of large blooms open at a time. Color a faintly tinted lavender on a rose pink ground. Lower petals have a large creamy white (almost white), throat clear down into the base. A fine florists' and showy garden variety. Each, \$1.00. Doz., $\$ 10.00$.

Silver Cloud (1930. 72 days.)--Very tall and stately plant with six or more very large flowers open at a time. Buds of a clear pure soft canary yellow. Flowers soft cream-white with single thread line of pink down the center of lower petals on a deep colored background which covers most of the lower petals. A very showy and fine variety. Each, 75c. Doz., \$7.50.

Silver Comet (1930. 77 days.)-Tall graceful plant with large widely expanded and gracefully recurved flower. Buds are the color of "Fern Kyle," but fully opened flower is a beautiful white with small fine pink lines on centers of lower petals and a slight faintly tinted cream background. A very pleasing and beautiful new white variety over five inches across and of fine texture. Each, $\$ 1.00$. Doz., $\$ 10.00$.

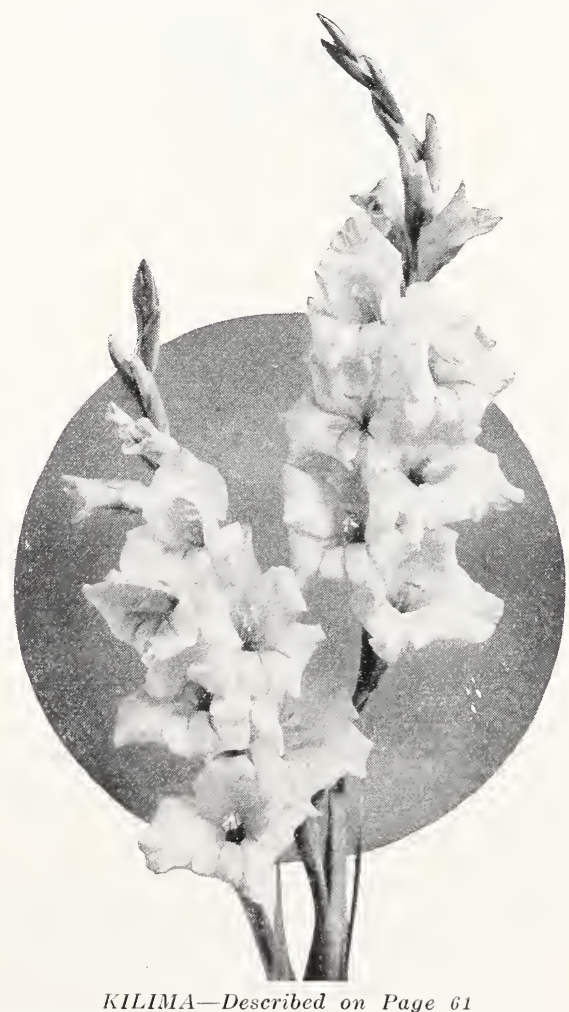

KILIMA-Described on Page 61 


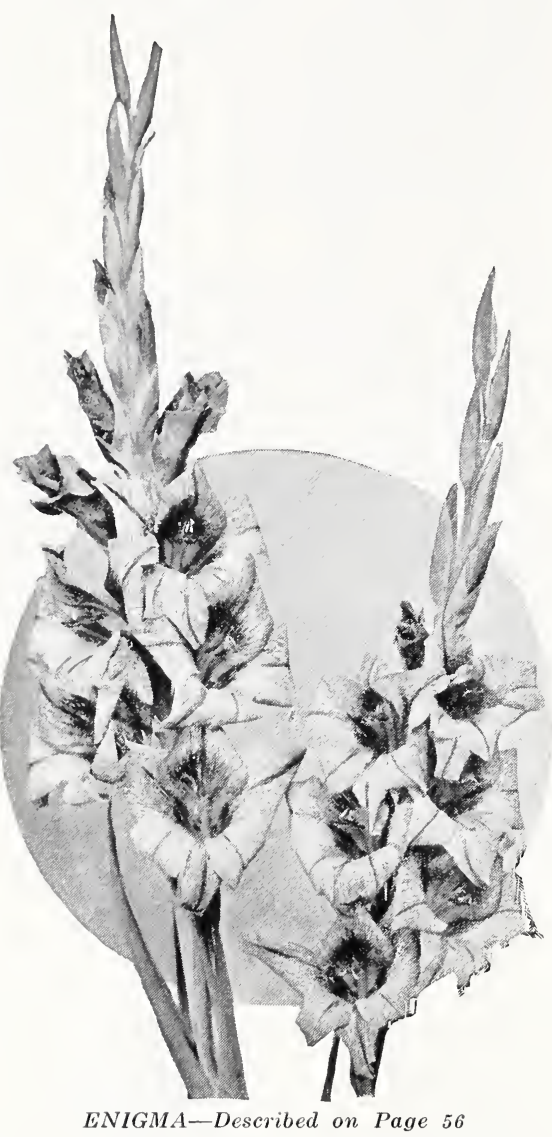

Snowy Morn (1930. 79 days.)-Medium tall plant and very large flowers, much the appearance of "Snow Boy," but finely blushed a faint lavender rose pink. A very elegant deep rose pink, widely feathered on both lower petals. A massive snowy and very fine lavender tinted white variety. Each, 75c. Doz., $\$ 7.50$.

Spangled Beauty (1930. 86 days.)-Tall graceful plant with six or more large perfect flowers open at a time. Color a fine dark rose pink, closely and finely flaked all over, giving the flowers almost a self color effect. Outer portion of lower petals somewhat deeper in color with considerably deeper rose red throat. Very showy and fine. An excellent variety. Each, $\$ 1.00$. Doz., $\$ 10.00$.

Spectrum Beauty (1930. 86 days.)-A fine medium height plant and good sized flowers, beautifully placed. Color a very striking tone of deep rose pink. Lower petals have large dark red blotches beautifully bordered soft creamy white. A very harmoniously blended variety. Each, 75c. Doz., \$7.50.

Stuart Merrill (1930. 68 days.)-Very tall and stately plant. Flowers very broadly expanded and "Recurved" petals very long, pointed and recurved like in a beautiful lily. Main color a delicate apple blossom pink of a beautiful flesh tone deepening considerably towards the outer portion. Lower petals very strikingly penciled and feathered rose red and white on a very dainty cream colored ground. Few, if any, lilies more beautiful. Extra showy and fine. Each, \$2.00. Doz., $\$ 20.00$.

Sunrise (1930. 82 days.)-Fine height and showy plant with large flowers. Flower, red mahogany with lower throat a brilliant glowing red. A distinct and showy garden variety of a decidedly rare color. Each, 75c. Doz., $\$ 7.50$.

Sun Rest (1930. 78 days.)-Tall stately plant with five or more very rich and very beautiful flowers open at a time. Color most vivid deep blood red. Large throat blotches much deeper velvety red. Mottled border of yellow extends beyond the blotches. This is another of those Gloxinia marked and colored varieties equal to an extra fine Gloxinia. Each, \$1.00. Doz., \$10.00.

Sweet Cherry (1930. 70 days.) - Fine showy tall plant and flower, five or more large flowers open at a time. Color of rich deep cherry rose, daintily flaked deeper. Much deeper cherry rose, velvety red over aimost all of the lower petals, only lighter on outer portions. An unusually rich and stately appearance. Extra fine. Each, $\$ 1.00$. Doz., $\$ 10.00$.

Symbol (1930. 84 days.)-Tall plant and large flowers, very beautiful and elegantly placed on the spike. Color a perfect pure deep rose pink. Lower petals a little deeper pure rose color. A fine rose pink gladiolus and as beautiful in every way as can be imagined. Each, \$2.00. Doz., \$20.00.

Tiger King (1930. 81 days.)-Large fine plant and large flowers. Six to eight open at a time facing perfectly and very uniform. Dark maroon red, very heavily flaked with much darker maroon. A distinct and magnificent blotch of fiery red covers the width of the central one-third of lower petals and extending down the throat. It is delicately and finely flaked white. Center of these blotches again has a dark 
velvety bird-like smaller blotch which extends outwardly in a subdued short white bar. Extending outwardly from the fiery blotch is another wide dark border. The whole flower is well entitled to the name of the Tiger King and is extremely striking and wonderful. Each, \$2.00. Doz., \$20.00.

Turkey Run (1930. 86 days.) - Fine strong plant with six or more very large and massive flowers open at a time. A little lighter in color than Marshall Foch and less ruffled, but more beautiful. Very distinct and massive in form and exceedingly showy and fine. Each, \$1.00. Doz., $\$ 10.00$.

United States (1930. 83 days.)-Medium tall, slender graceful plant. Medium large flowers, a little deeper in color than "America" and delicately and faintly flaked soft pink. Throat has a very fine wide feathered blotch of a rich bright light red. A dainty and beautiful gladiolus reminding of "America," but distinct type and color. Each, 75c. Doz., \$7.50.
Weesie (1930. 82 days.)-Tall and very stately and graceful plant with six to eight or more very perfectly placed blooms open at a time. Color a deep salmon or shrimp red of very richest appearance. Throat a little deeper on lower petals in a soft rose pink. General appearance decidedly rich, pure and distinct. Extra fine and beautiful. A treat for 1930. Each, $\$ 1.00$. Doz., $\$ 10.00$.

White Feather (1930. 90 days.)-Tall, stately plant and large showy white flowers beautifully placed. Lower petals have wide bars beautifully feathered. An unusually fine and beautiful white with a distinct and showy throat. Choice and fine. Each, $\$ 1.00$. Doz.s $\$ 10.00$.

W. L. Holcomb (1930. 88 days.)-Strong, vigorous plant with six or more large, beautifully placed flowers. General effect, white finely blushed and feathered towards the edges of all the petals. Throat a delicate creamy pink, beautifully feathered on a soft creamy colored base. Each, 75c. Doz., \$7.50.

\section{Collection Offers}

\section{PLAIN PETALED INTRODUCTIONS}

These Collections Are All Sent with Each Variety Properly Labeled

Collection No. 29-All varieties valued at 75c, 27 in all (value $\$ 20.25)$ for $\ldots \ldots \ldots \ldots \ldots \ldots \ldots \ldots 17.20$

Collection No. 30-All varieties valued up to and including 75c, 29 in all (value $\$ 21.25$ ) for........\$18.05

Collection No. 31-All varieties valued up to and including $\$ 1.00,71$ in all (value $\$ 63.25$ ) for....\$53.75

Collection No. 32-All varieties valued up to and including $\$ 2.00,92$ in all (value $\$ 105.25$ ) for... $\$ 89.45$

Collection No. 33-Entire collection, one each of the 97 varieties listed (value $\$ 120.25$ ) for.......\$102.20

Varieties Included in These Collections Are Listed on Pages 36 to 47

A. E. Kunderd, Goshen, Indiana 
From the Golden Gate of California to the Metropolis of the East, Kunderd Gladioli have won premier honors at Gladiolus shows. In this classification are the varieties de luxe, gladioli that have never been surpassed for beauly or perfection. Each year finds them more popular than the year before. They will be loved more and more as time goes

on. These favorites should be in the garden of every flower lover.

Achillas (1928. 76 days.)-A tall, strong plant. Giant, deep orange red flowers with very beautiful and showy, large, vermilion scarlet throat blotches. Edges of blotches and base of throat daintily stippled with richest yellow. A magnificent, large and showy flower in every way. Each, \$2.00. Doz., \$20.00.

A-Flame (1929. 69 days.)-Medium tall plant with a giant flower of very beautiful orange red color flaked a beautiful lighter shade. Throat has a large beautiful dark red feather, elegantly

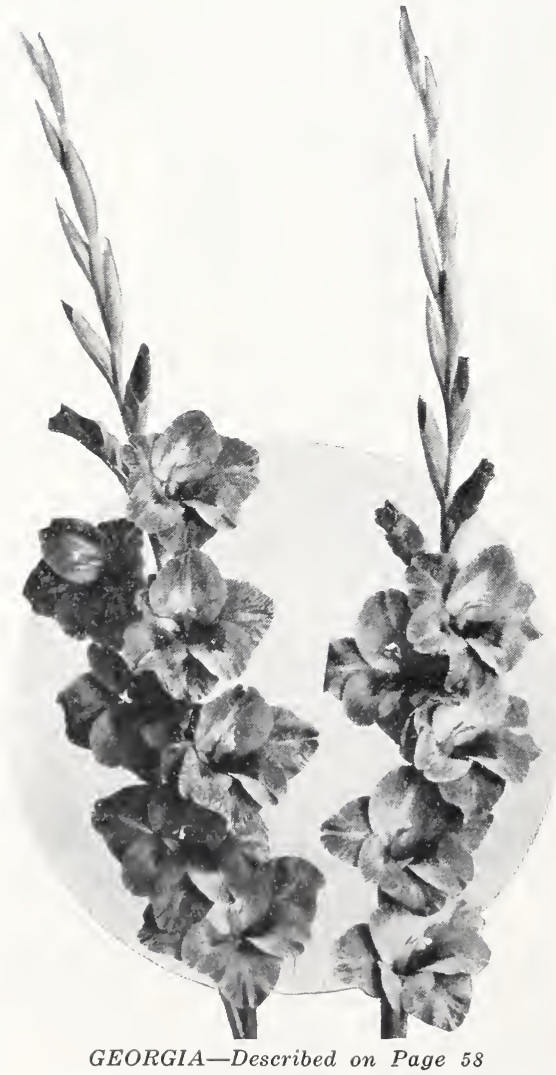

stippled and flaked on a soft yellow ground. A very showy and beautiful large flowered gladiolus of distinct and striking appearance. Each, 50c. Doz., $\$ 5.00$.

Ah (1922. 85 days.)-Pale apricot-pink and yellow. Medium sized flower on vigorous plant and foliage. Has a very beautiful opening bud reminding one of "Ophelia" rose. Illustrated on page 65. Each, 15c. Doz., \$1.50. 100, \$11.25.

Anthony Zonker (1922. 96 days.)-Extra tall, strong plant with five to seven very large, wide open blooms open at a time. Finest deep salmon-rose, beautifully placed. Lower petals as beautifully blotched as "Pendleton." A distinct and showy flower named for a grand old man, my mother's father. Classed among the best. Each, 15c. Doz., \$1.50. 100, \$11.25.

Antonia Antonette (1926. 80 days.)Tall, strong plant with many flowers open at a time. Color, a very striking salmon rose-pink. Neat throat marking: of deeper pink and white, finely blended. A very unusual and beautiful pink of grand appearance. Each, 20c. Doz., \$2.00. 100, $\$ 15.00$.

Al. Smith (1929. 66 days.)-Tall strong plant and large flowers perfectly placed on spikes and perfectly facing one way. Color of finest and purest salmon rose slightly flaked deep salmon red on outer tips of petals. Lower petals deeper on inner throat half portion with a very beautiful purplish central bar which is paralleled with fine veinings, interspersed with delicate pencilings of soft yellow, giving the whole a very beautiful effect. Easily one of the most beautiful of all Gladioli. Each, \$1.00. Doz., $\$ 10.00$.

Ambrosia (1929. 72 days.)-Tall fine plant with five or more large and showy blooms open at a time. Color the most refined old rose imaginable with giant blotch of beautiful deep yellow which again has a fine blotch of rich red extending down into the throat. An extraordinary showy and

See Special Collection Offers, Pages 15, 21, 30, 35, 47, 74, 75, 81, 83 


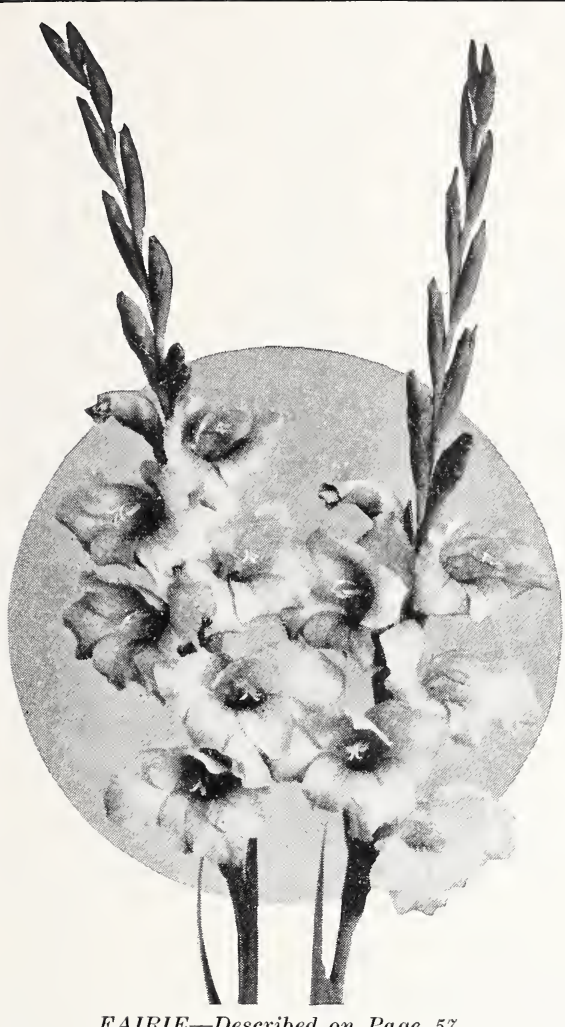

FAIRIE-Described on Page 57

beautiful flower. Each, \$5.00. Doz., $\$ 50.00$.

Arthur Brisbane (1928. 71 days.)-Tall, handsome plant with large, wide open, deep rose pink or light rose red flowers and beautiful, deeper rose red towards the outer petals. Large, deep red throat blotches, with a deeper, velvety red in center of blotches. As finely marked as a pansy. A very beautiful gladiolus. Each, 35c. Doz., \$3.50. $100, \$ 26.25$.

Ashburn (1917. 70 days.) - A very massive salmon-red, flaked deeper. Showy. Illustrated on page 73. Each, 15c. Doz., $\$ 1.50$. 100, \$11.25.

A. T. De La Mare (1928. 85 days.)Strong, vigorous plant with large, massive flowers, beautifully placed. Color of finest rose pink, a little lighter in upper portion of throat. Lower petals of same color but with a very vivid, brilliant red throat blotch. A very outstanding, showy and beautiful flower in every way. Each, 25c. Doz., \$2.50. 100, \$18.75.

Atreus (1921. 77 days.)-Grandest, pure rose-pink of most delicate shade. Strong grower and very, very beautiful. Each, 15c. Doz., \$1.50. 100, $\$ 11.25$.
Autumn Colors (1928. 145 days.)-Strong plant with large flowers. Quartinianus type. Autumn flowering. Color a bright orange red with light yellow throat markings. Fine for fall blooming. Each, 75c. Doz., \$7.50.

Avantis (1928. 72 days.)-Tall, strong plant. Large flower of Pendleton type. Lavender purple on a white ground. Large and showy deep purple, claret blotch covering entire width from throat and fully three-fourths of broad lower petals. Unusual. Each, \$2.00. Doz., $\$ 20.00$.

Baby Blushes (1928. 80 days.)-Tall, strong spike and fine plant. Flowers very large, open and perfectly placed. A very beautiful white with faintly blushed or flaked outer edges. The lower large broad petals same color on outer half with fine creamy or soft yellow throat. A first-class tinted white. Illustrated on page 53. Each, 50c. Doz., $\$ 5.00$.

Battle Creek (1923. 71 days.)-An attractive, almost self-colored deepviolet, a little deeper in throat. Good size and many open at a time. Each, 10c. Doz., \$1.00. 100, \$7.50.

Beverly (1926. 79 days.) -Very fine, showy plant. Good number flowers open. Color of a beautiful violet-rose. Elegant, deep-red. throat blotches. Each, 15c. Doz, \$1.50. 100, \$11.25.

Big Black (1915. 86 days.)-An extra large flower of a very pure, rich, deepred, self-color. Very rich, distinct and showy. The best, large, dark-red. Each, 15c. Doz., \$1.50. 100, \$11.25.

Black Pansy (1915. 77 days.) - Of richest dark-red. Beautiful, pansy-like throat. Extra. A general favorite. Each, 10c. Doz., $\$ 1.00$. 100, $\$ 7.50$.

Blue Isle (1916. 79 days.) - A good sized lilac-blue, dark-red blotches. None better in this class. Illustrated on page 17. Each, 25c. Doz., $\$ 2.50$. 100, $\$ 18.75$. Beauty Flower (1929. 95 days.)-Fine medium tall plant with ample wide open flowers in bloom at a time. In color a clear bright violet red slightly flaked deep velvety dark red. The throat has a very large dark purple red blotch beautifully stippled at the edges with a soft creamy yellow. Upper petals have a similar blotch on each side. Each, \$3.00. Doz., \$30.00.

Blue Lily (1921. 69 days.) - Light violetblue. Medium size flowers. Five and six open at a time. Graceful stem. Each, 20c. Doz., \$2.00. 100, \$15.00.

Blue Orchid (1916. 75 days.)-Rich, selfviolet blue. Black blotch with golden heart on lower petals. Extra. Each, 15c. Doz., \$1.50. 100, \$11.25.

Blushes of Cream (1929. 88 days.)-Fine height shapely plant with many (eight 


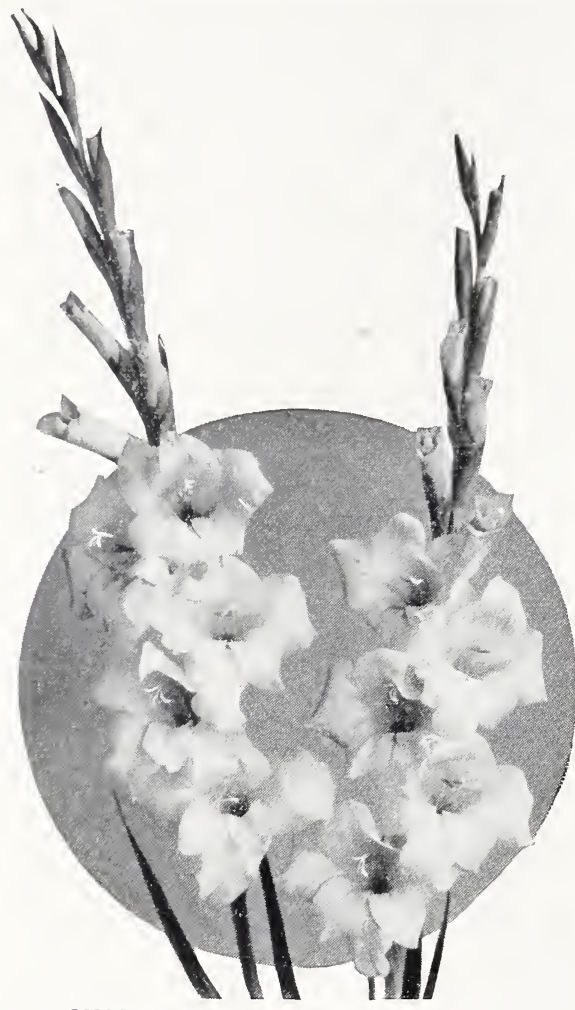

MISS U. S. A.-Described on Page 63

or more), very beautiful and refined flowers open at a time. Color one of those beautiful apricots, blushed deeper in upper throat. Lower throat a very delicate canary yellow blending into the beautiful delicate apricot, or flesh pink. Of great beauty. Must be seen to be appreciated. Each, $\$ 2.00$. Doz., $\$ 20.00$.

Bobby (1925. 78 days.)-An immense and beautiful deep-rose with extra large and beautiful bluish-red throat blotches. First-class. Each, 35c. Doz., $\$ 3.50$. $100, \$ 26.25$.

Buena (1928. 76 days.)-Tall, fine plant. Many large flowers, diamond form, open at a time. A fine light rose pink on a white ground, flaked a brilliant deep rose pink. Lower petals a little deeper red, beautifully penciled and with deep, velvety red central bars. A showy and pretty variety. Each, 35c. Doz., \$3.50. 100, \$26.25.

Byron L. Smith (1917. 76 days.)-One of the very best. Most refined lavenderpink on white ground. Exceedingly fine as a cut flower. Color equal to a very choice cattleya orchid. Winner of many award: Illustrated on page 44. Each, 15c. Doz., \$1.50. 100, \$11.25.
Cardinal Prince (1924. 69 days.)-A magnificent self-colored cardinal. Flowers large and of splendid form and placement, six to eight open at a time. A good, tall plant. An A-1 cardinal, far superior to any other variety in this color. Destined to become very popular. Illustrated on page 53. Each, 25c. Doz., \$2.50. 100, \$18.75.

C. C. Sherlock (1928. 69 days.)-Fine shapely plant with ample good sized flowers open at a time. Flowers of purest deep salmon red imaginable. A deeper toning on outer portions. Throat a little lighter with fine central bars on all the petals. Throat on lower petals has beautiful pure selfcolored blotches of soft canary yellow perfectly blended with the salmon red main color. Illustrated on page 53. Each, 75c. Doz., \$7.50.

Carmine Rose (1928. 84 days.)-Good height plant. Fine plant with good sized flowers and plenty open at a time. Color a fine shade of carmine rose, deeper on lower petals. A very good gladiolus in this color. Each, 20c. Doz., \$2.00. 100, $\$ 15.00$.

Challenger (1915. 88 days.) - Very large and vigorous plant. Giant, dark, rich, velvety-red, solid color. An extraordinary fine variety. Each, 10c. Doz., $\$ 1.00$. 100, $\$ 7.50$.

Chancellor (1928. 70 days.)-Tall, fine and shapely plant. Large flowers, plenty open and perfectly placed on spikes. Color deep violet red delicately flaked or shaded deeper red on outer edges. Lower petals darker with a very dark, wide, rich, velvety red throat covering full width of the petals and has an almost black red central bar on mid rib. Each, 20c. Doz., \$2.00. 100, $\$ 15.00$.

Charles F. Fairbanks (1925. 82 days.)Another red, but a distinct and beautiful variety named in honor of a recent President of the American Gladiolus Society. I have worked up a good-sized stock of this variety, believing it will be in big demand as soon as brought to public attention. Illustrated on inside front cover. Each, 15c. Doz., \$1.50. $100, \$ 11.25$.

Cherry Rose (Quartinianus Hybrid) (1927. 83 days.)-Tall, strong plant and spike. Flowers wide open. Rich cherry-rose color. Central portion of lower petals have beautiful penciled feathers. Feathers barred deeper rosered interspersed with white on a creamy ground. The entire flower is distinct and of pleasing appearance. Well worthy of the space in every garden. Each, 35c. Doz., \$3.50. 100, \$26.25. (Continued on Page 55) 

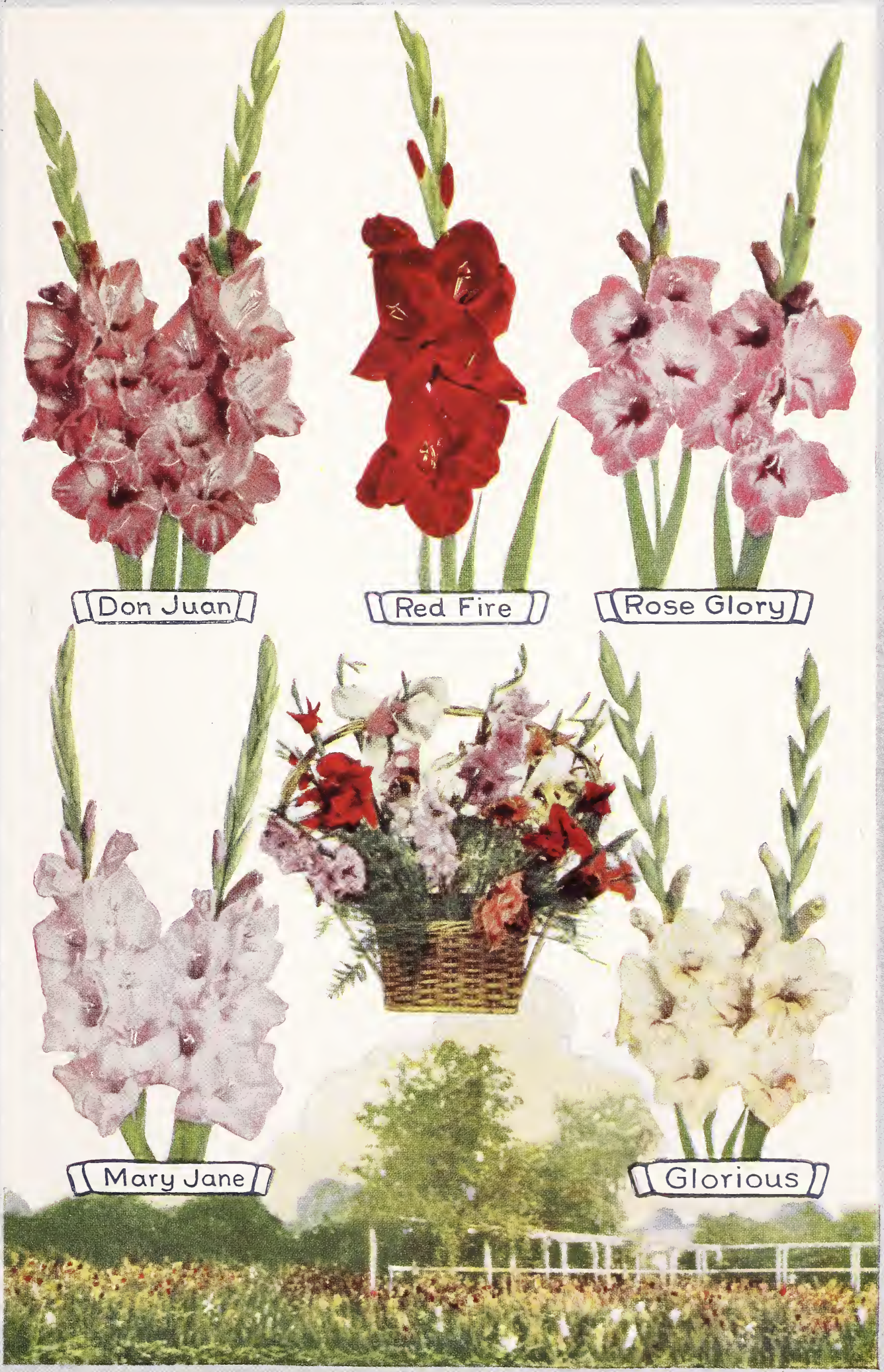


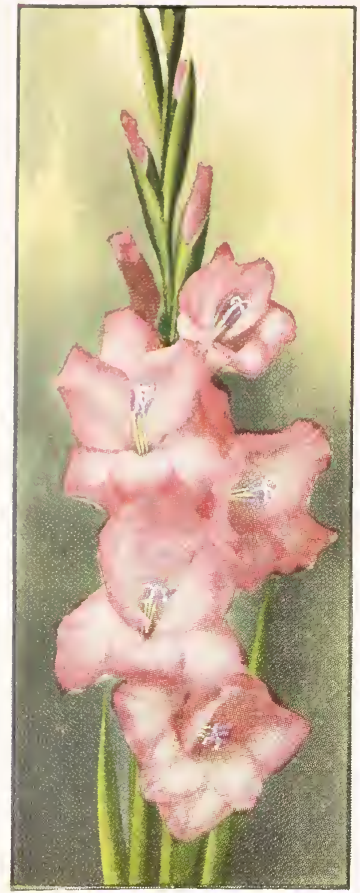

Paramount

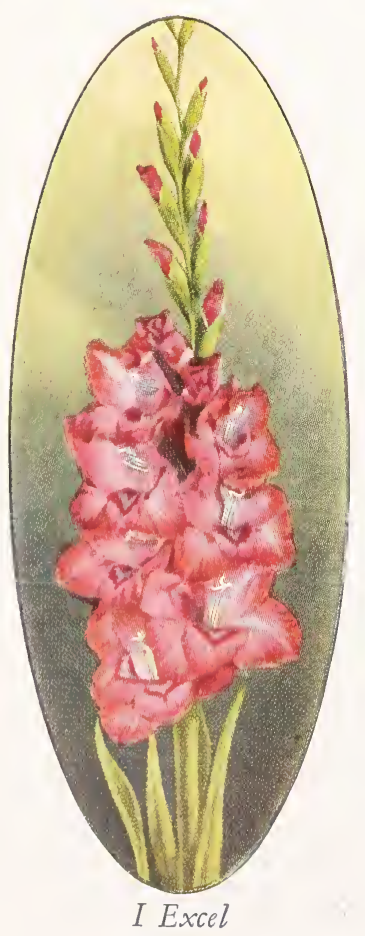

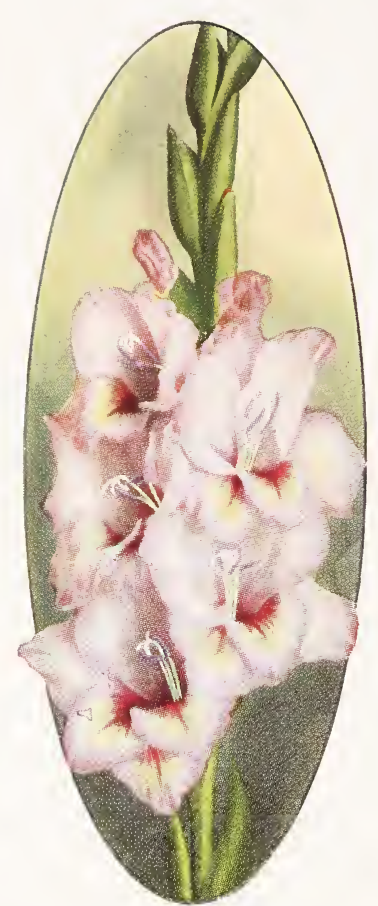

Evening Glory

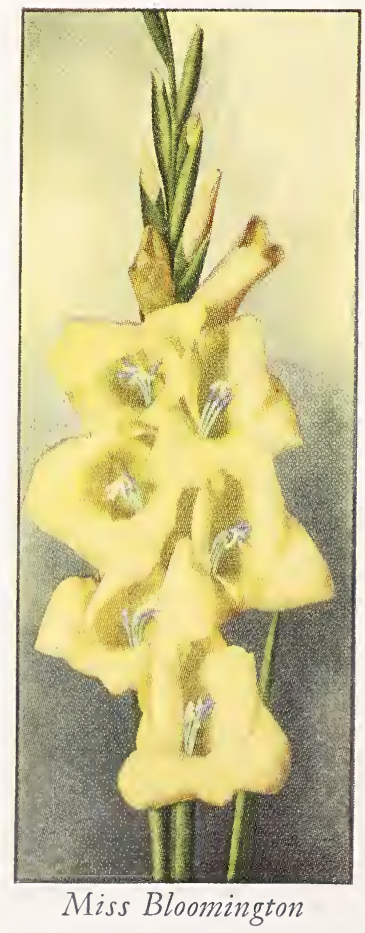

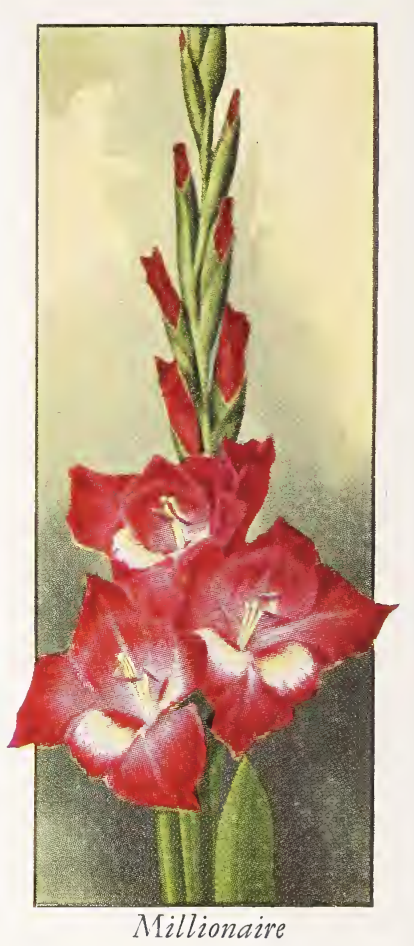

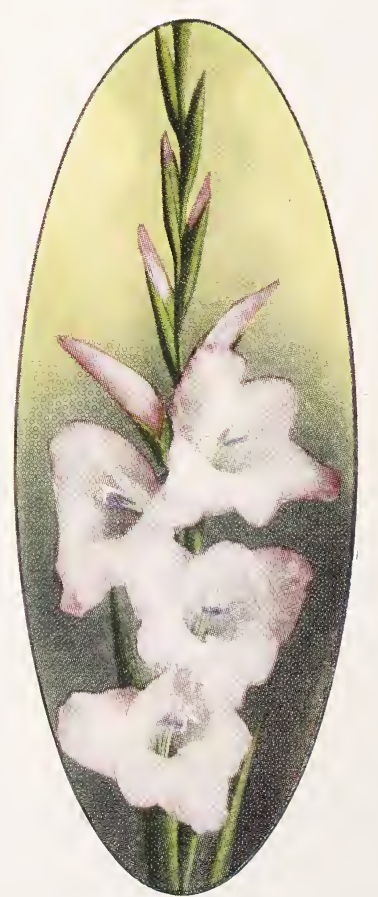

Dr. J. H. Neeley

For Descriptions of Color Illustrations Refer to Index 


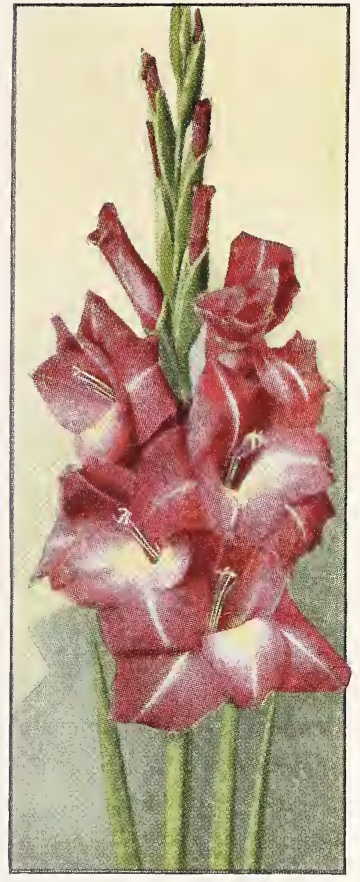

C. C. Sherlock

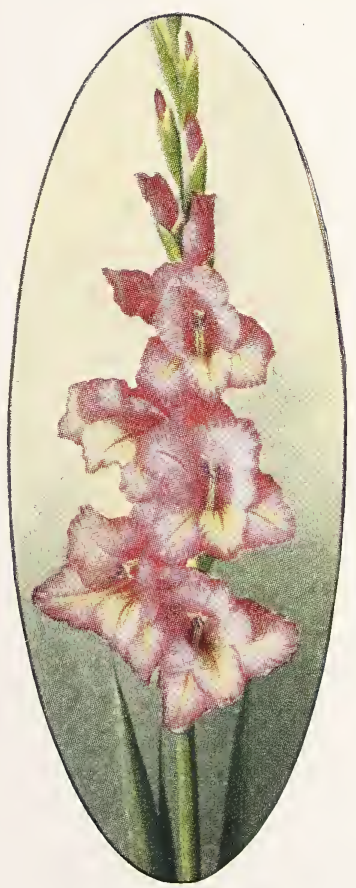

Coral Pink

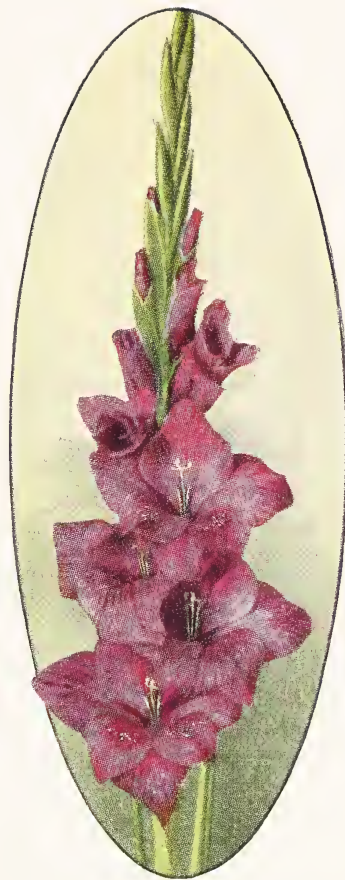

Mrs. Chas. A. Stevens

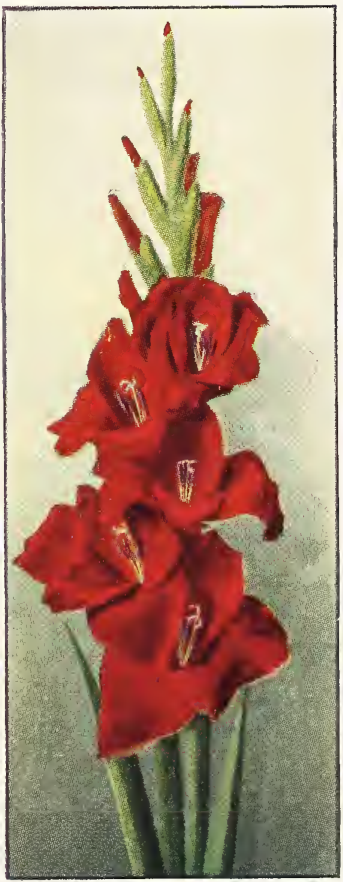

Cardinal Prince
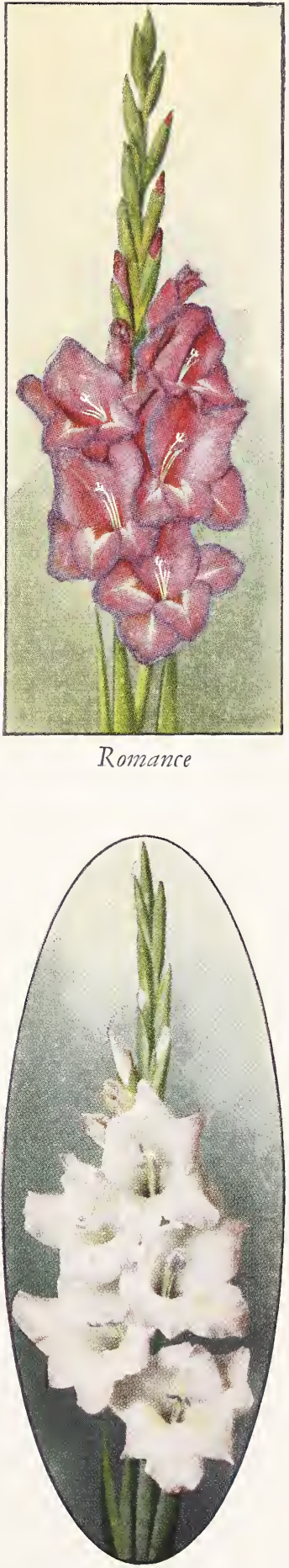

Baby Blusbes

For Descriptions of Color Illustrations Refer to Index 


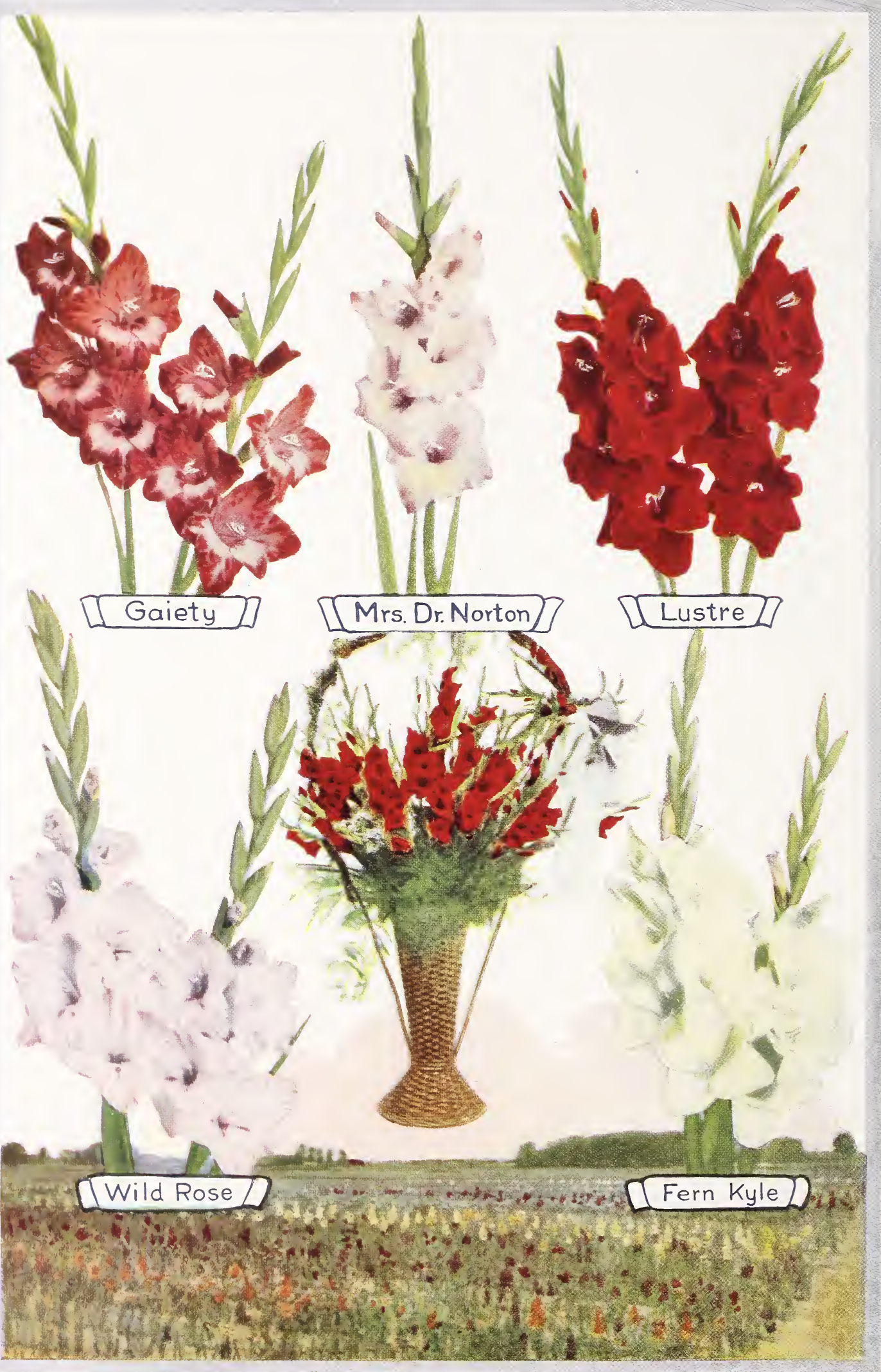

For Descriptions of Color Illustrations Refer to Index 
(Continued from Page 50)

Circe (1916. 73 days.) - Very early, tall, deep dark-red. A large, extra fine, dark flower Each, 15c. Doz., \$1.50. 100, $\$ 11.25$.

Cleo (1927. 77 days.)-Slender, graceful plant, but strong. Medium sized flowers of lavender-rose tint on a whitelike ground. The strikingly mottled and veined blotches on lower petals make this a very attractive variety. Each, 20c. Doz., \$2.00. 100, \$15.00.

Col. Chas. Lindbergh (1928. 76 days.)Tall, stately plant. Flowers large and widely open, and of a beautiful, broad butterfly form. Many open at a time and perfectly arranged on spike. A refined rose with fine lavender tint on a white ground on upper petals. Lower petals covered two-thirds with soft, pastel creamy yellow. Very finely and beautifully stippled and central bars of fine cream color extending beyond the blotches. Ends of lower petals of same Cattleya rose color as the upper petals. A very extra and high class variety. One of the most distinct and beautiful gladioli ever produced. Each, \$2.00. Doz., $\$ 20.00$.

Colors (1928. 77 days.)-Tall, fine plant and large flowers of deep rose pink or red. Very large and showy. Beautiful deep velvety red throat blotches "like a Gloxinia" bordered with a soft yellow which is beautifully stippled. Each, 75c. Doz., \$7.50.

Darkest (1916. 75 days.) $-\mathrm{Sl}$ e n d e r, graceful plant and neat flower. The darkest red I have. Attractive. Each, 35c. Doz., \$3.50. 100, \$26.25.

Delicacy (1928. 79 days.) - A tall, fine plant with a very beautiful and delicate deep rose pink flower. Large and wide open. Throat white very delicately blended with pink. Fine florists' flower and fine for every purpose. Each, 25c. Doz., \$2.50. 100, \$18.75.

Dorritt (1920. 75 days.) - A large, delicate colored lavender-pink with rosered throat markings and quite often splashed with rose-red on all petals. A very popular variety. Each, 15c. Doz., \$1.50. 100, \$11.25.

Dr. Elkins (1922. 81 days.) - A true sport from "Mrs. Frank Pendleton." Same large and showy flower, but the original rose-pink has changed to a white and the large throat blotches to a fine shade of lilac-blue. A distinct and classy flower and a decided acquisition. Each, 20c. Doz., \$2.00. 100, $\$ 15.00$.

Dr. David Griffith (1929. 77 days.)Quite tall and stately plant. Flowers of very remarkable form. Tubular and as upright as a tuberose or a crocus. An altogether unusual type and ex- ceptionally attractive. Color is a beautifully slight lavender blush of pink over all six petals. Throat a little deeper blushed. And back of neck of the flower is a deep rose pink giving a very striking effect. All six petals of same coloring rarely showing the slightest of marking. A unique and remarkable form. Showy and beautiful. (No crocus is as beautiful.) Each, \$5.00.

Dominus (1929. 69 days.)-Tall fine shapely plant with seven and more perfect blooms, all facing one way, open at a time. Color is hard to describe. It is of a very deep dark red yet not of a blackish shade. Beautiful still darker throat blotches with a slight white line extending a little beyond all the blotches. A velvety finish over all and in all respects an exceedingly distinct and showy variety. Scarce. Each, \$2.00. Doz., \$20.00.

Dr. J. H. Neeley (1923. 76 days.)-Tall, massive plant. Very large and refined flower of finest blushed white. Throat clear and clean, pure, soft white, tinted softest light canary-yellow or cream. A grand variety. Illustrated on page 52. Each, 15c. Doz., \$1.50. $100, \$ 11.25$.

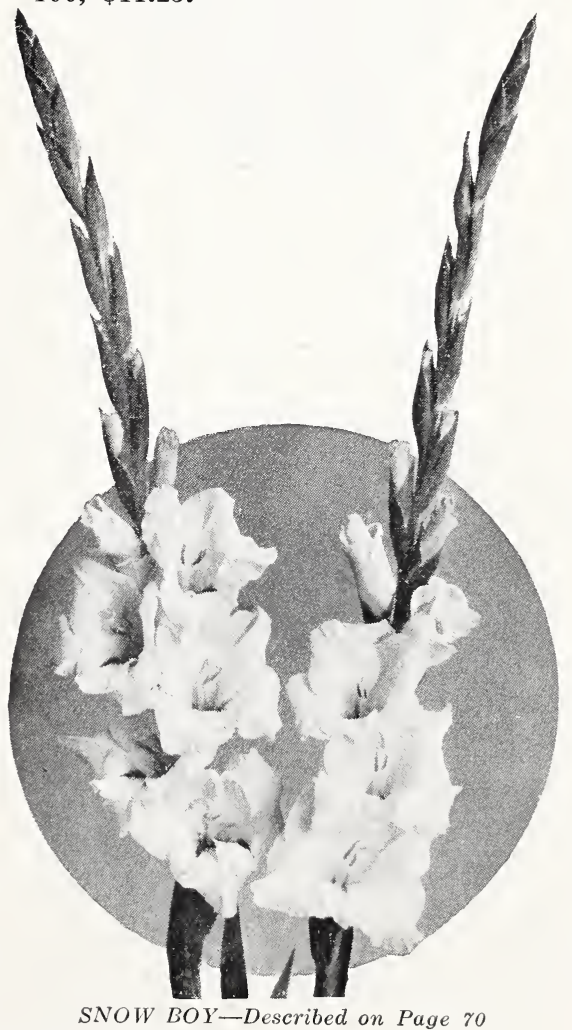

SNOW BOY-Described on Page 70

\section{A. E. Kunderd, Goshen, Indiana}




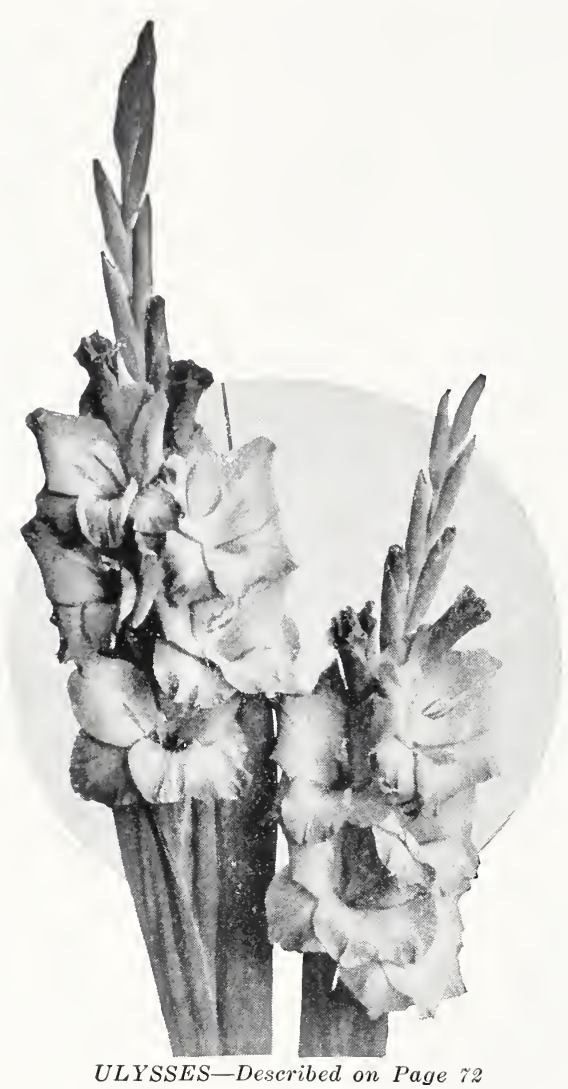

Dr. R. L. Starkweather (1929. 69 days.) - Tall strong plant with very large flowers of a beautiful lavender rose with large and beautiful blotches much like "Pendleton" on lower petals. Very large and showy plant and flowers. This variety is destined to become a favorite both for the garden and florist use. Each, \$1.00. Doz., $\$ 10.00$.

Dream Flower (1928. 85 days.)-Tall, sturdy plant, very large flowers and many open at a time. An "America" seedling of very imposing appearance. Entire flower has a very beautiful shade of pure, soft pink a little deeper than "America" and throat blotches deeper and showier than "America." A very extra florists' flower and a magnificent bedding variety. Each, $\$ 2.00$. Doz., $\$ 20.00$.

Duchess (1926. 89 days.)-Late midseason. Fine plant and spike. Flowers of a fine shade of light watermelon-red with darker red in throat. Fine. Each, 10c. Doz., \$1.00. 100, \$7.50.

Eestasy (1928. 83 days.)-(A Gloxinia, too.) A dark, rich cherry red much like Emblem but considerably darker and like the other carries its blotches on all six petals. On the upper central top petal it gives the snapdragon form to the blossoms. A rich, showy flower for the garden. Distinct and rare type of striking appearance. Each, 75c. Doz., $\$ 7.50$.

Ed Springer (1926. 83 days.)-Strong, fine plant, showy flowers of light lavender rose-pink. Outer edges of petals are a stronger rose-pink color, somewhat flaked. Lower petals have fine rose-red markings bordered and tinted white. Each, 35c. Doz., \$3.50. 100, $\$ 26.25$.

Eighth Wonder (Quartinianus Hybrid) (1927. 89 days.)-Deep, smoky oldrose with a lighter undertone. Lower petals of same color but delicately mottled and flaked with central lines of red. Very large plant with many large blooms open at a time. Each, $\$ 1.00$. Doz., $\$ 10.00$.

Elkhart (1917. 83 days.) -Violet purple, deeper throat blotch. An exceedingly fine variety. Very rich in color. Each, $\$ 1.00$.

Elrose (1929. 79 days.) - Very tall showy plant with very large flowers widely opened. Soft rose pink lightening in upper portion. Flaked deep rose pink and deeper on outer ends of petals. Throat deep cherry red with still deeper central lines. A very showy and fine striped variety. Each, \$2.00. Doz., $\$ 20.00$.

Emblem (1928. 77 days.)-Fine plant and large flowers, six or more open at a time. This is a very unusual, extraordinary and beautiful variety. It is as wonderfully marked as a magnificent Gloxinia. In color a rich cherry red with a very remarkable throat coloring which runs over all six petals. On the lower three it covers first a large, dark, velvety, ruby red blotch wonderfully bordered by two distinct additional color zones. First a very dark, deep red about one-fourth inch wide. This is bordered again by soft yellow, very beautifully striped with red. A wonderful and showy flower in every way. Illustrated on inside front cover. Each, $\$ 2.00$. Doz., $\$ 20.00$.

Enigma (1921. 76 days.)-Tall plant with large flowers. Strikingly striped red, white and blue. Is all that the name implies. Illustrated on paga 46. Each, 20c. Doz., \$2.00. 100, $\$ 15.00$.

Estella (1916. 75 days.)-One of the largest gladioli. Fine, deep rose-pink. Mammoth and beautiful. Each 10c. Doz., \$1.00.

E. W. Allis (1926. 88 days.) - Tall, fine plant with many large, beautiful flow- 
ers open at a time. Color of finest shade of spectrum or scarlet-red. Upper portion of throat much lighter, lower portion deeper shade of bloodred. A winner. Each, 20c. Doz., \$2.00. $100, \$ 15.00$.

Excellence (1927. 69 days.)-Large, fine grower. Blooms large, and a good number open at a time. Color a deep orange-vermilion. Self-color in effect but faint throat mark of slightly deeper shade. Strong, round, open flowers with large lower petals. Conspicuous and very attractive. Each, 35c. Doz., \$3.50. 100, \$26.25.

Fairest White (1918. 79 days.)-Purest white, softest pink throat lines. Ethereally beautiful. Illustrated on page 67. Each, 10c. Doz., \$1.00. 100, $\$ 7.50$.

Fairmont (1929. 85 days.)-Tall slender plant with beautiful butterfly like flower of a bright deep tyrian rose red color. Lower petals in throat deep dark red with velvety blackish red central bars with a sheen approaching delicate bronze towards throat. Upper throat portion nearly white, beautifully veined. Entire back of flowers a pure self rose red. Tall stately striking variety. Each, 75c. Doz., \$7.50.

Fairie (1915. 80 days.) - A delicate, creamy-pink flower with cream throat. Very fine. Illustrated on page 49. Each, 10c. Doz., \$1.00. 100, \$7.50.

Fairview (1928. 77 days.)-Many large flowers open at a time. Petals colored deeper towards the outer ends. Throat blotches, on lower petals, of deep, velvety red with deeper central bars. Edges of blotches beautifully stippled, giving a very rich pansy-like effect. Very choice and showy. Each, 50c. Doz., $\$ 5.00$.

Fairy Maid (1928. 95 days.)-Very tall and graceful plant. Many beautiful, velvety scarlet flowers open at a time. Throats have fine, large canary yellow blotches, ends of lower petals of same scarlet color as upper petals. A finely branched and showy bedding or garden variety. Each, 25c. Doz., \$2.50. $100, \$ 18.75$.

Fantasy (1928. 74 days.)-Tall, graceful, slender plant with six or more perfectly placed flowers open at a time. Color a deep, reddish, dark, violet purple, hard to describe. Lower petals nearly covered with a velvety purple (almost like in Baron J. Hulot) with deep red central bars. A choice dark purple, better than Baron J. Hulot, much larger and showier. Each, $\$ 1.00$. Doz., $\$ 10.00$.

Fawn Gold (1929. 66 days.)_-Tall, strong and perfect plant. Very large flowers and six or more open at a time, beautifully placed but not crowded. Color deep rich fawn to light golden. Large and very striking pale red blotches on lower petals with deeper red central bars extending beyond the showy blotches. Edges of blotches also a deeper red blended into a rich yellow. A magnificent variety in every way. Each, 75c. Doz., \$7.50.

Fidelity (1928. 72 days.)-Tall, strong, elegant plant with large flowers and plenty open at a time, perfectly placed. Back of flowers and upper portion of throat a very striking deep, soft, lavender rose pink. Outer ends of lower petals much lighter. Lower petals on outer half a delicate creamy color of pleasing effect. Lower portion of throat beautifully penciled and stippled on a fine primrose yellow ground. The whole flower is of unusual color effects and beautiful. Each, 50c. Doz., \$5.00.

Fire Ribbon (1915. 67 days.)_Tall, with many blooms open at a time. The spike is a long, fiery band of glowing red. Exceedingly rich and strikingly showy. Each, 10c. Doz., \$1.00. 100, $\$ 7.50$.

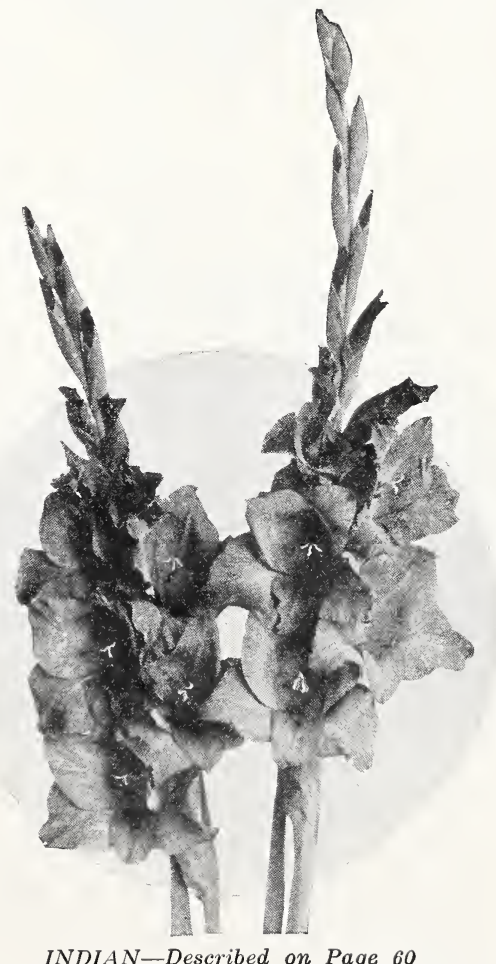

INDIAN-Described on Page 60 


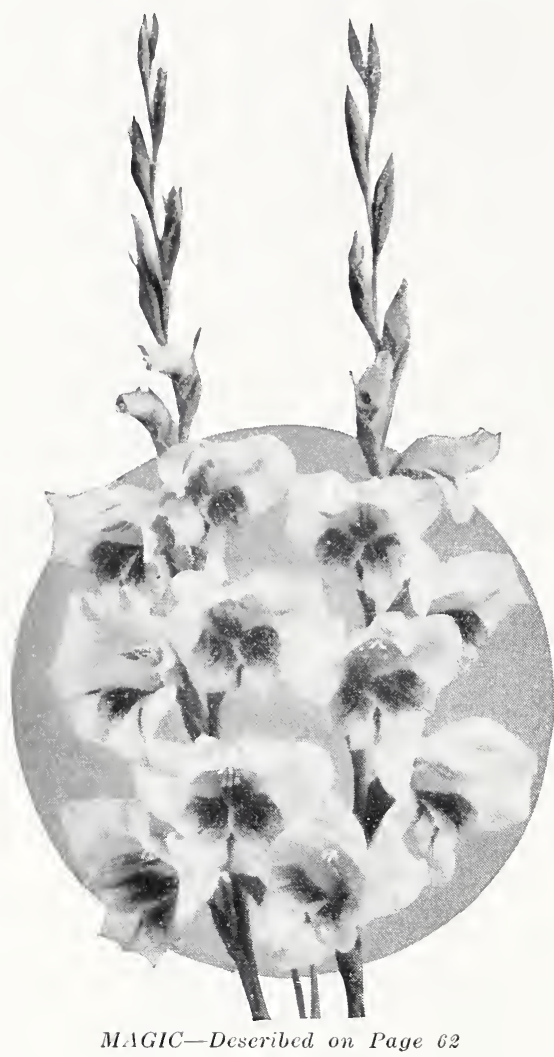

Fire Glow (1929. 72 days.) - Tall stately plant. Flowers of good size and of most intense vivid glowing scarlet. Almost a pure "self." Exceedingly brilliant and showy. Each, \$1.00. Doz., $\$ 10.00$.

Fire Pink (1929. 80 days.) - Tall fine plant with six or more very beautiful deep salmon red blooms open at a time. Of richest glowing deepest salmon red, purest self color over entire flowers. One of the very grandest of all. Scarce. Each, \$1.00. Doz., \$10.00.

Fire Torch (1929. 69 days.)—Quite tall but very slender plant. Small upright flowers of the most intense fiery scarlet imaginable. Very unique and pretty. Each, 50c. Doz., \$5.00.

Flame of Fire (1928. 66 days.) -A very fiery, glowing orange vermilion. Perfectly clear color without flaking but deeper orange lower petals and central bars still deeper shade of same color. Fine, graceful spike. Flowers of good medium size and plenty open. Decidedly distinct and none more brilliant. A rare treat. Each, 25c. Doz., $\$ 2.50$. 100, \$18.75.
Flaming Vale (1921. 74 days.)-Very tall; long spikes with large, deep, cardinal-red flowers. Throat a little deeper. Pure self-color effect. Very good. Each, 15c. Doz., \$1.50. 100, $\$ 11.25$.

Fuld's Favorite (1927. 102 days.)-Massive flowers of delicate, light lavenderrose. Lower petals of same color on outer portions with deeper rose colored throat laid on a ground color of delicate cream. Average of eight and nine flowers open at a time. Tall and strong plant. This variety was the favorite of the late Maurice Fuld, organizer of the American Gladiolus Sociecy, and whose judgment of fine gladioli ranked high. No doubt this choice new variety will become very popular. Stock yet limited. Each, 50c. Doz., \$5.00.

Gaiety (1915. 75 days.)-Bright salmon. pink, flaked deep salmon-red. Very conspicuous pure white blotches on lower petals. Large flower and tall spikes. Exceptionally attractive. Illustrated on page 54. Each, 10c. Doz., $\$ 1.00$. 100, $\$ 7.50$.

Gene Stratton Porter (1925. 86 days.) -A distinct and beautiful soft tone of pink. Of very delicate and beautiful appearance. Late. Each, 25̃c. Doz., $\$ 2.50$. 100, \$18.75.

Georgia (Kunderd's) (1926. 73 days.)Tall, fine, graceful plant and foliage. Many beautifully and elegantly placed blooms open at a time. Color of bright, deep amaranth purplish-red with elegant throat blotches of dark amaranth-red. Illustrated on page 48. Each, 35c. Doz., \$3.50. 100, \$26.25.

Glory Flower (1928. 66 days.)-Medium tall. Large flowers, upper petals of rose lavender tint. Lower petals of same color at outer edges with a large creamy blotch on lower two-thirds of petals. Deeper in throat with a fine rose colored blotch. The whole flower is very distinct. A first-class gladiolus. Each, 75c. Doz., \$7.50.

Golden Buff (1918. 76 days.) -Goldenbuff color. Lower petals yellow with beautiful feather-like throat markings. Distinct and fine. Illustrated on page 71. Each, 10c. Doz., \$1.00. 100, \$7.50. Golden Fringe (1928. 88 days.) - Tall and vigorous plant. Flowers large and of a soft orange on upper petals. Lower petals orange red in throat and outer portion blending to a lighter orange red. All lower petals are delicately bordered with a narrow golden yellow fringe. Very striking, unusual and beautiful. Each, 50c. Doz., \$5.00.

Golden Pink (1928. 80 days.)-Tall, strong plant and large flowers. Upper portion a beautiful, distinct shade of 
soft pink, lower petals a dainty, soft cream yellow with a very pretty red central line. Outer ends of petals similar shade but lighter than upper petals. The whole effect of flowers very pleasing and attractive. Each, 35c. Doz., \$3.50. 100, \$26.25.

Gold Star (1928. 69 days.) - Medium tall, perfect plant with large perfectly placed, deep yellow flowers. Lower petals of still deeper yellow, like a very richly colored golden daffodil. Many flowers open at a time. An ideal landscape and florists' variety. A very low price for such a grand yellow. Each, 75c. Doz., \$7.50.

Gorgeous (1929. 80 days.)-Fine good height plant. Large rich rose-red flowers having a very vivid deep dark red velvet-like throat blotch, as rich as the blotch in "Pendleton." No richer throat blotch in any variety. Extra grand and showy. Each, $\$ 2.00$. Doz., $\$ 20.00$.

Goshen (1923. 83 days.) - A fine Pendleton seedling of medium deep silvery rose-pink color. Large, showy rose-red blotches. Very good. Each, 15c. Doz., $\$ 1.50$. 100, \$11.25.

Gov. Hanly (1915. 65 days.) - Tall, showy, early, rich cardinal-red, with deeper throat color. First-class bedding and cut-flower variety. Each, 10c. Doz., \$1.00. 100, \$7.50.

Grand Glory (1928. 79 days.) - Very tall giant plant and massive flowers. Petals a golden orange with a beautiful yellow throat. Both colors perfectly blended together. An immense and showy variety. Magnificent. Each, $\$ 2.00$. Doz., $\$ 20.00$.

Graphic (1928. 67 days.) — Good height. Very large flowers of outstanding and distinct appearance. Soft, deep, mellow purple or deep tyrian pink. Blotches on lower petals a fine deep rhodamine purple red. A very attractive and showy flower. Illustrated on page 17. Each, 25c. Doz., \$2.50. 100, $\$ 18.75$.

Herald (1928. 97 days.)-Tall, graceful plant and large and very showy flowers of a decided deep, rich rose red. Upper throat a little lighter. Lower petals and throat much deeper dark velvety red. A very showy and beautiful variety. Each, 50c. Doz., \$5.00.

Herbert Hoover (1929. 74 days.)-Fine good height plant with plenty good sized bright deep cherry-rose red blooms open at a time. Large throat blotches, of deep blackish crimson becoming almost scarlet at the upper edge, gives same striking effect that "Mrs. Frank Pendleton" does. A very beautiful variety. Each, \$1.00. Doz., $\$ 10.00$.
Hestia (1927. 72 days.)-An exquisite beautiful deep-cream on three upper petals. Lower petals much deeper, turning to a fine, soft canary-yellow on inner portion. Bars on lower petals of deep-pink. Many large, well formed flowers open at a time on strong spike and plant. A distinct and pleasing new variety, which I am sure will please my flower loving friends. Each, 15c. Doz., \$1.50. 100, \$11.25.

Highland Laddie (1925. 85 days.) Large, massive and beautiful pink of a decided and pleasing shade. A very choice kind and a rapid multiplier. Illustrated on inside front cover. Each, 15c. Doz., \$1.50. 100, \$11.25.

Ida Van (1915. 76 days.) - A most beautiful, deep salmon-red, or flaming orange-pink. Very rich and brilliant color. Highest award at Cleveland, and certificate of merit. Each, 10c. Doz., \$1.00. 100, \$7.50.

I Excel (1916. 80 days.) - Very tall. Large flower. Bright, light rose-red. Many open. Magnificent throat. Il-

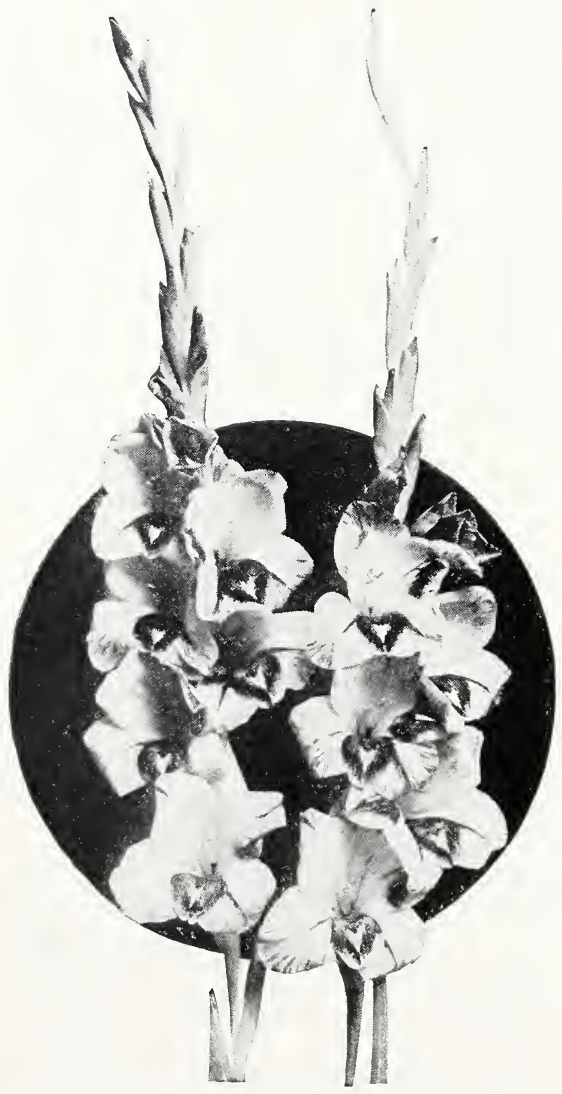

PRES. LINCOLN-Described on Page 66 
lustrated on page 52. Each, 10c. Doz., $\$ 1.00 .100, \$ 7.50$.

Immensity (1921. 92 days.) —Tall, strong plant. Bright salmon color. Very large flowers and many open at a time. Very choice. Won first prize as best American production two years in succession at the Mid-western Gladiolus Show, Des Moines, 1924 and 1925. Illustrated on page 18. Each, 20c. Doz., \$2.00. 100, \$15.00.

Imperial Chimes (1928. 66 days.)-Fine, graceful slender plant and foliage. Flowers large and plenty open at a time. Color intense dark, velvety crimson black or maroon. Lower petals entirely covered still darker and has a fine subdued lighter red narrow median line. No better dark or black red. Each, 50c. Doz., \$5.00.

Imperium (1928. 96 days.)-Extra strong and tall, fine plant. Flowers very large and widely open. Color fine, deep rose pink or light cherry red. Lower petals deeper bright red and have an extra fine bluish red central bar. A perfect and a very beautiful variety. Each, 35c. Doz., \$3.50. 100, $\$ 26.25$.

Indian (1921. 71 days.)-Strong plant, large, well expanded flowers. Many open at a time. Color of deep aniline or Indian-red. Illustrated on page 57. Each, 15c. Doz., \$1.50. 100, \$11.25.

Indian Chief (Quartinianus Hybrid) 1927. 84 days.) -Deep-red with bluishpurple tint. Lower petals deeper with still deeper dark-red median lines blended at the edges a clear red. An exquisitely beautiful, late red variety. Each, 50c. Doz., \$5.00.

Indian Maid (1922. 82 days.)_Tall plant and fine stem. Flowers of beautiful peach-blossom pink with beautiful deeper throat. Very choice and distinct. Each, 10c. Doz., \$1.00. 100, $\$ 7.50$.

Intramura (1928. 86 days.)-A strong, splendid plant with many large, beautiful flowers open at a time. Color almost exactly "America" over again. Perhaps better and has a good deal better plant. Very choice and fine. Each, 50c. Doz., \$5.00.

Iroquois (1929. 70 days.)-Fine medium height and shapely plant. Ample blooms open at a time. Color of deepest dark ruby red. Throat much deeper, almost a black dahlia red. Entire flower over back and face of flowers a very glowing velvety sheen. One of the richest and showiest deep velvety reds imaginable. A striking variety. Each, \$3.00.

Isolita (1929. 69 days.)-Medium height plant with good sized blooms of deep purple slightly flaked deeper. Very large dark velvety purple blotches. Very showy and richly colored. Each, 50c. Doz., $\$ 5.00$.

Jacelia (1929. 71 days.)-Good height and shapely plant with eight or more perfectly placed blooms open at a time with all facing perfectly one way. Color glowing deep rose pink lighter in upper throat, lower petals deeper bright rose red and clearly bordered with narrow white edge. A distinct richly colored flower. Each, $\$ 1.00$. Doz., \$10.00.

J. D. Oliver (1925. 87 days.) - Plant, foliage and spike all of giant proportions. Flowers a pleasing lavenderrose. The many good sized blooms open at a time give this variety a decidedly distinct and outstanding appearance. Illustrated on page 70. Each, 35c. Doz., \$3.50. 100, \$26.25.

J. Horace McFarland (1927. 88 days.) -Extra tall, vigorous plant. Very large flowers approaching g o lde $\mathrm{d}$ ophelia rose-color. Lower petals pure, deep canary-yellow. Some of the petals will occasionally be orange-red, but the whole effect is as described above. At a slight distance the effect of these

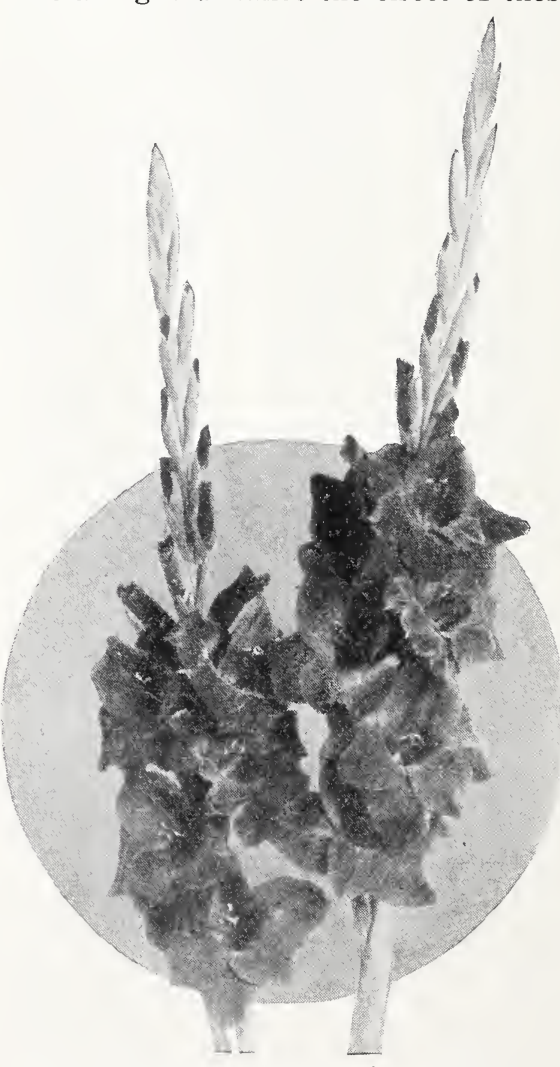

ROYAL PURPLE-Described on Page 69 
colors is remarkable. Sure to become a great favorite. Named in honor of one of America's foremost horticulturists. Each, \$1.00. Doz., \$10.00.

J. J. Mitchell (1926. 80 days.)-Very tall, graceful spike and plant. Large blooms of fine salmon rose-pink. Finely marked throat. Each, 15c. Doz., \$1.50. 100, \$11.25.

John Dunbar (1923. 77 days.) - A red of very striking beauty and appearance. Intense and velvety red color with a sort of dark coppery bronze sheen, difficult to describe. Sometimes give a bent spike, which in a fine variety is very decorative. Each, 10c. Doz., $\$ 1.00$. 100, $\$ 7.50$.

John T. MeCutcheon (1925. 73 days.) A giant wonder red, something like "Bobby," yet decidedly different and beautiful. Named for the great cartoonist. Each, 25c. Doz., \$2.50. 100, $\$ 18.75$.

John T. Pirie (1922. 87 days.)-An exceptionally colored variety and very beautiful. A sort of mahogany-brown with remarkable yellow bordered dark mahogany-brown throat. In a class by itself and should be in every collection. Each, 25c. Doz., \$2.50. 100, \$18.75.

Joseph J. Lane (1928. 72 days.) - Slender, graceful plant. Flower of richest, showy, deep tyrian rose red. Fine central bars of deeper velvety tyrian red. Of the popular color of "Mrs. Geo. W. Moulton." A very pleasing and fine gladiolus. Beautiful. Each, 25c. Doz., \$2.50. 100, \$18.75.

Kilima (1918. 80 days.)-Tall, slender plant. Beautiful creamy salmon blush. Very elegant. Illustrated on page 45. Each, 10c. Doz., \$1.00. 100, \$7.50.

King of Reds (1929. 92 days.)-A giant fiery crimson scarlet with deeper throat. Fine good plant. Very extra red. Each, \$2.00. Doz., \$20.00.

Kunderd's Yellow Favorite (1927. 74 days.)-Rich, deep, yellowish-fawn on back of petals. Entire face of flower deep-yellow with deeper yellow on lower petals. Throat finely feathered and penciled soft-red. The plant is tall and stately. Excellent variety. Illustrated on page 62. Each, 35c. Doz., $\$ 3.50$. 100, \$26.25.

Kunderd's Yellow Wonder (1926. 72 days.)-Tall, vigorous plant and a very rapid multiplier. Flower large and seven to eight open. Almost buttercup-yellow, slightly deeper in throat, without the least marking. Has every point of a perfect gladiolus and is the finest yellow yet produced. This variety won first prize in two classes as the best yellow, also a basket of this variety together with a basket each of Dr. Nelson Shook, Sweet Rose,
Tiger and Helga was awarded the Executive Committee's Silver Cup at the A. G. S. show, 1926. Illustrated on page 39. Each, 35c. Doz., \$3.50.

Lavender America (1915. 68 days.)-A very large, beautiful flower of most artistic form and striking general appearance. Solid lavender color. Tall plant, strong grower, rapid multiplier. Beautifully arranged in a funeral piece and shown at the A. G. S. show, Rochester, Aug., 1925, this variety was awarded first prize for best funeral piece of lavender gladioli, A. G. S. Bronze Medal. Won two first prizes at the Mid-western Gladiolus Show, Des Moines, Sept., 1925, for best lavender. Again in 1926, this variety was awarded another A. G. S. Trophy. Each, 15c. Doz., \$1.50. 100, \$11.25.

Lavender Glow (1928. 86 days.)-Tall, strong plant. Very big flowers, broad, wide open and upright. Color a fine, deep lavender rose pink with a pretty, dark, velvety red throat terminated by a narrow central white mid rib or line. All six petals deeper on outer portion and lighted up softer lavender blush in upper portion of throat. A distinct, good gladiolus. Each, 35c. Doz., \$3.50. $100, \$ 26.25$.

Lavender Rose (1928. 84 days.)-Tall, stately and very graceful plant and fine foliage. Flowers large and very perfectly placed. Color is a most decidedly pure and beautiful delicate rose pink with beautiful blush of lavender. Central narrow bars of petals softest daffodil yellow. Lower petals have a beautiful delicate yellow blotch feathered rose pink at edges. A magnificent gladiolus and unsurpassed in beauty. Each, \$5.00.

Leonard Barron (1928. 77 days.)-Good, large plant with large diamond shaped flowers beautifully placed on spike. Ground color a brilliant rose red with rose blushed white median lines on all six petals. Upper throat lighter, lower darker. The whole flower very distinct, showy and beautiful. Each, 35c. Doz., \$3.50. 100, \$26.25.

Lexington (1927. 86 days.)-Tall, stately and graceful plant. Foliage extra fine. Color a rich vermilion, lighter in upper throat with beautiful, soft, bluish tint on outer portion. Lower petals same color but deeper in throat. Fine, darkred, central lines. One of the finest cut spikes of all gladioli. A perfect spike, easily cut at great length without injury to foliage. A very beautiful red. Each, 25c. Doz., \$2.50. 100, $\$ 18.75$.

Loella (1918. 89 days.) - Smoky oldrose. Flaked deep smoky-blue. Very

\section{A. E. Kunderd, Goshen, Indiana}




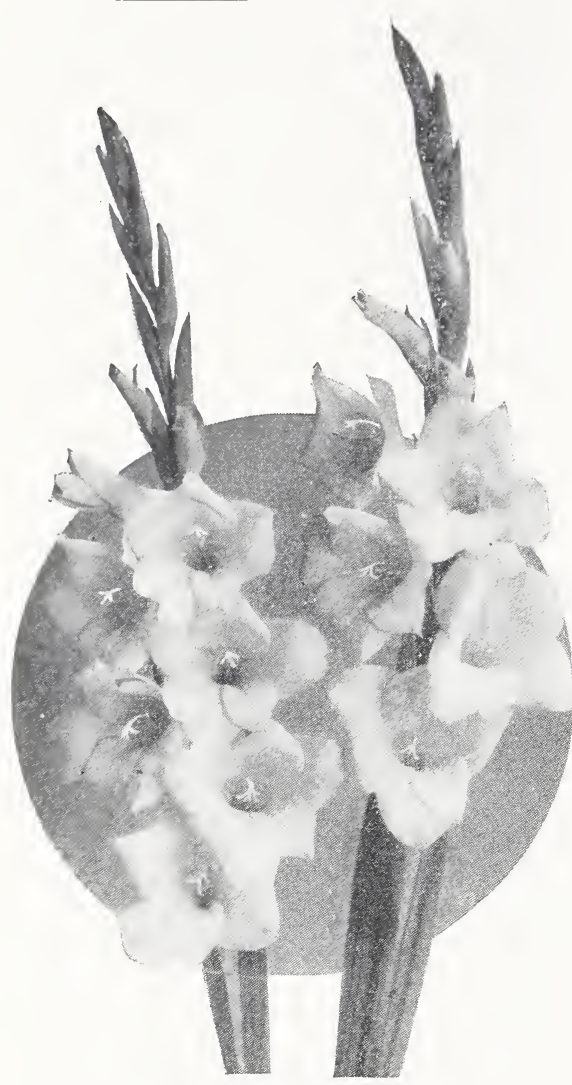

KUNDERD'S YELLOW FAVORITE Described on Page 61

unusual and fine. Illustrated on inside back cover. Each, 15c. Doz., \$1.50. 100, $\$ 11.25$.

Lustre (1918. 87 days.) - Tall, large flowered orange-vermilion. Grand and beautiful. Illustrated on page 54 . Each, 15c. Doz., \$1.50. 100, \$11.25.

Luverne (1917. 73 days.) - Tall, salmonflesh pink. Cream throat, beautifully mottled crimson. The best pink and crimson variegated variety. $\mathrm{Rich}$, grand flower. Each, 25c. Doz., \$2.50. $100, \$ 18.75$.

Magic (1915. 67 days.) - Tall, finest lavender-blue. I a $\mathrm{rge}$, rich, purple throat blotches. Fine. A very admirable basket made up of this variety and Purple Pansy received an A. G. S. Trophy for the best funeral basket at the 1926 A. G. S. show. Illustrated on page 58. Each, 10c. Doz., \$1.00. 100, $\$ 7.50$.

Mary Jane (1925. 81 days.) —A plain petaled variety, which I have decided to name in honor of my beloved mother. A beautiful, silvery pink with light lavender sheen. Delicate, clear throat and many large, perfectly placed flowers open at a time. This variety won first prize for best new seedling at the A. G. S. shows, Kalamazoo, 1922. The Garden Club of America's silver medal. It was also awarded first prize at the Mid-western Gladiolus Show, Des Moines, Sept., 1925 , for the best variety selling that year for more than $\$ 10.00$ per bulb. Illustrated on page 51. Each, \$1.00. Doz., \$10.00.

Mary Pickford (1915. 70 days.) - A extraordinary flower and spike of most delicate creamy-white. Throat finest, soit sulphur-yellow. Stem and calix also white. Was awarded Certificate of Merit by Royal Horticultural Society, London, Aug. 10, 1920; also First Class Certificate of Merit by North Shore Horticultural Society, Manchester, Mass., summer of 1919 , and winner of hundreds of other awards. Awarded first prize as best cream colored gladiolus without marking at A. G. S. show, Rochester, Aug., 1925. Illustrated on page 68. Each, 10c. Doz., \$1.03. 100, \$7.50.

Magnificent (1928. 85 days.)-Extra tall and strong plant. Flowers large, massive and plenty open at a time. Ground color, a very mellow soft purple magnificently flaked deep purple red. Lower petals almost covered a deep, bright velvety red. A truly magnificent and showy flower. Each, $\$ 2.00$. Doz., $\$ 20.00$.

Mahogany King (1928. 98 days.)-Tall, strong, stately plant. Flowers large, many open, perfectly placed. Color a very rich deep mahogany or brown red. Ends of petals a little brighter red. Very large, wide, elongated, pure white throat blotch with bright red, prettily feathered red border between the white throat and the ground color. A very extra and showy variety. Very desirable. Each, 75c. Doz., \$7.50.

Mary Fennell (1917. 81 days.)-Deeplilac, shading paler. Soft primroseyellow throat. Extra. Each, 10c. Doz., $\$ 1.00$. 100, $\$ 7.50$.

May Day (1928. 74 days.)-Fine, tall plant with a large, wide open flower and six or more open at a time. Color soft orange red with a white throat and dainty white lines minutely traced over all six petals. Unique but showy and fine. Each, 35c. Doz., \$3.50. 100, $\$ 26.25$.

Metropolis (1928. 77 days.)_Tall, strong and beautiful plant. Color a light lavender rose with beautiful, deep, lavender rose red throat blotches. Color very pleasing. Only moderately ruffled. Very beautiful opening buds. Each, 35c. Doz., \$3.50. 100, \$26.25. 
Midas (1928. 83 days.) - F'ine height plant with giant, wide open flowers which are widely expanded and perfectly placed. Color a deep tyrian reddish purple. Lower petals have large, deeper red blotches. A very showy flower and fine for every purpose. Each, 50c. Doz., \$5.00.

Millionaire (1926. 65 days.)-Tall, elegant plant, many large flowers open at a time. Flowers richest velvety crimson, beautifully flaked geraniumred. Lower petals flaked deeper. Throat deeper red with cream y blotches, finely mottled and stippled. Very attractive variety. Illustrated on page 52. Each, 25c. Doz., \$2.50. 100, $\$ 18.75$.

Miss Bloomington (1929. 67 days.)-A very tall giant plant with six to eight or more very large, perfectly placed, rich lemon yellow blooms open at a time. A perfect self, only a little deeper yellow on lower petals. A wonderful grand, showy giant yellow. Illustrated on page 52. Each, \$1.00. Doz., $\$ 10.00$.

Miss U. S. A. (1918. 77 days.)-Dain. tiest blush white. Very pure, refined and beautiful. Illustrated on page 50 . Each, 10c. Doz., \$1.00. 100, \$7.50.

Miss Universe (1929. 76 days.)-A neat plant of good height with six or more perfectly placed beautiful flowers open at a time. Bright red tyrian rose. Throat has large clear deep tyrian rose red blotch. A very striking flower greatly admired by all visitors at the field. Each, \$5.00. Doz., \$50.00.

Modesty (1928. 88 days.)-Fine, strong plant with large flowers and six or more open at a time. Color a fine, light rose pink, and a large, deep rose red blotch in throat, with a dark red median line. Much like a "Pendleton" and very showy. Each, 25c. Doz., $\$ 2.50$. 100, \$18.75.

Mommie Dietz (1927. 74 days.)-Tall, strong plant. Many large flowers open at a time. Color deep rose-pink of a very pleasing shade. Throat daintily marked deeper with fine, white pencilings. Entire flower finely flaked with finest shade of soft rose-red. This is one of the most unusual and beautiful of all gladioli. Each, 75c. Doz., \$7.50.

Mrs. Chas. A. Stevens (1929. 72 days.) -Nice shapely plant of medium height with six to eight large blooms facing perfectly open at a time. Color a very fine shade of mellow purple all beautifully flaked a very rich deep rhodamine purple. Outside of petals deeper. Throat stippled a fine purple on a subdued white ground. One of the most beautiful gladioli imaginable. Illustrated on page 53. Each, \$2.00. Doz., $\$ 20.00$.

Mrs. Arthur Meeker (1917. 83 days.)Exceptionally fine, rich, deep American Beauty rose color. A very beautiful and unusual color. Illustrated on page 17. Each, 20c. Doz., \$2.00. 100, $\$ 15.00$.

Mrs. J. C. Bruggen (1926. 66 days.)Tall, elegant plant. Beautiful spike for cut flowers. Color light begoniarose or deep eosine-pink according to Ridgeway Color Chart. Beautiful, clear white $\mathrm{throat}$ harmoniously blended with the rose and pink. Among the most popular varieties. Each, 20c. Doz., \$2.00. 100, $\$ 15.00$.

Mrs. Paul Dieball (1929. 85 days.)Extra tall fine plant with numerous very large and showy blooms open at a time. Color a decided glowing deep salmon pink. Lower throat somewhat deeper salmon. One of the most showy, distinct, and beautiful gladioli ever produced. Each, 75c. Doz., \$7.50.

Mrs. Dr. Norton (1915. 78 days.)Finest cream and pink. The sensation

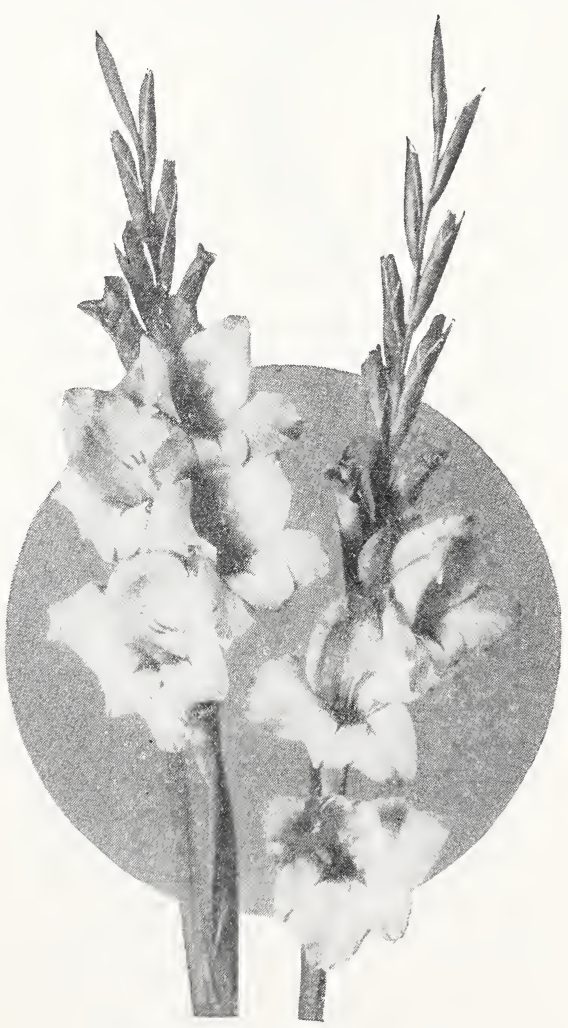

GRAPIIC-Described on Page 59

A. E. Kunderd, Goshen, Indiana 


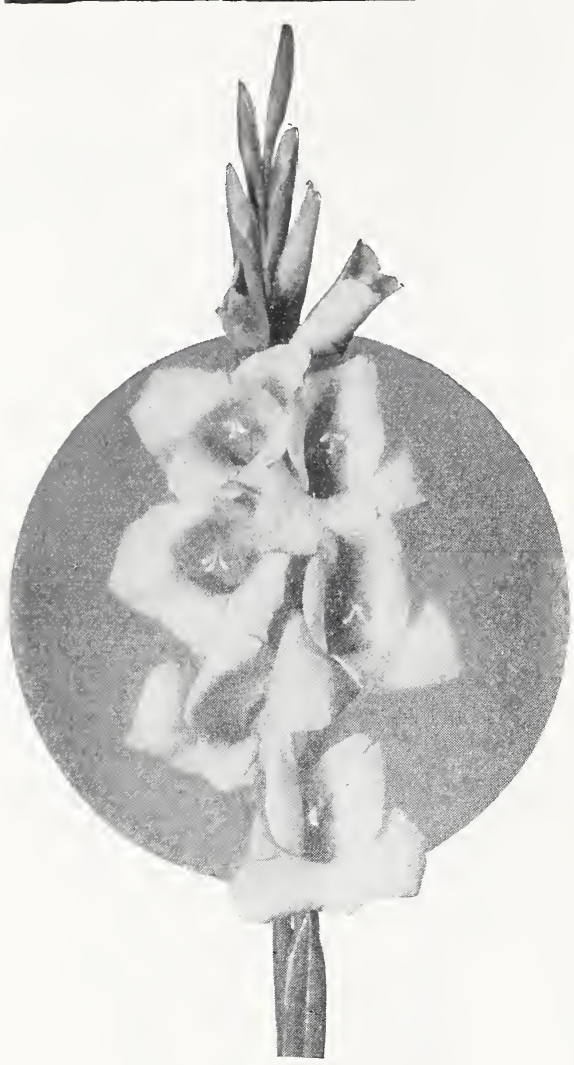

MISS BLOOMINGTON-Described on Page 63

at the American Gladiolus Society's shows. Everywhere awarded the highest honors. Illustrated on page 54 . Each, 10c. Doz., \$1.00. 100, \$7.50.

Mrs. Frank Pendleton (1910. 76 days.) -Bright rose-pink on a pure white ground. A giant blotch of richest carmine-red on lower petals. No grander variety in existence. Awarded highest honors at the American Gladiolus Society, Mass. Horticultural Society, and many others. Illustrated on page 17. Each, 10c. Doz., \$1.00. $100, \$ 7.50$.

Mrs. Geo. W. Moulton (1915. 73 days.) -A giant, violet, red or cerise. Many open. Nicely placed on spike. An occasional blossom comes double. This variety was awarded first prize for the best rose colored gladiolus with markings at A. G. S. show, 1926. Illustrated on inside back cover. Each, 15c. Doz., \$1.50. 100, \$11.25.

Mrs. Walter Lytton (1929. 74 days.) Strong medium height plant with six to eight very massive blooms open at a time. Color a glowing pure deep salmon flesh over all the petals. Throat on lower petals of purest delicate creamy white faintly penciled toward the base. A very distinct and beautiful variety. Easily among the best. Each, \$1.00. Doz., \$10.00.

Merton W. Wentworth (1919. 74 days.) -Very tall and stately plant, blooms large and widely open outer petals delicate pink, shading to Marechal Niel yellow. Backs of petals show a tint of very delicate lavender. Lower petals wonderfully blotched American Beauty rose color. Each, 15c. Doz., $\$ 1.50$. $100, \$ 11.25$.

Myrtle (1915. 69 days.) - Very delicate pink variety. Exceptional for cutting and as a florist flower rates as one of the finest. Each, 10c. Doz., \$1.00. 100, $\$ 7.50$.

October (Quartinianus Hybrid) (1927. 85 days.) - Deep old rose red or wine color, of very large size. Flaked deeper. Throat charmingly marked red with fine white pencilings. A splendid garden and vase variety. Each, 35c. Doz., \$3.50. 100, \$26.25.

Opaline (1928. 105 days.)-Strong, vigorous plant, large, massive flowers. Color soft, mellow violet purple. Fine, deep red throat. Very good for every purpose. Very showy and effective. Each, 25c. Doz., \$2.50. 100, \$18.75.

Orange Glow (1923. 69 days.) - Very tall, showy spikes with glowing, orange salmon flowers. Exceptionally distinct and striking. Each, 15c. Doz., $\$ 1.50$. 100, \$11.25.

Orange Gold (1929. 74 days.) - Tall strong plant with flowers of a deep dark orange red, almost blood orange. Throat still a deeper red. Flowers very large and widely open. One of the most conspicuous and showy of all Gladioli. Wonderful, ext $\mathrm{r}$ a grand. Each, \$2.00. Doz., \$20.00.

Orange Plume (1923. 70 days.) - Fine plant with beautiful drooping foliage. Large, pure, deep orange-red with softly blended, pure white central lines on all petals. Lower petals more white, with red central portions. Illustrated on page 43. Each, 20c. Doz., $\$ 2.00$. 100, $\$ 15.00$.

Orchidian (1928. 66 days.)-Tall, stately plant with many large, perfectly placed flowers open at a time. Upper petals deep violet pink. Entire lower petals covered a beautiful, velvety, deep claret red, with edges beautifully bordered same color as the upper petals. Very striking with noticeable orchid colorings. Each, 75c. Doz., $\$ 7.50$.

Orient (1929. 80 days.)-Tall slender graceful plant with five or more large perfectly placed blooms open at a time. Color a rich pure smoky old 
rose over upper petals. Lower petals deeper and of a bluish old rose color on outer portions. Large throat blotches of pure white edged or bordered soft salmon red towards the old rose blue on ends of lower petals. A very beautiful old rose colored variety. Each, 75c. Doz., \$7.50.

Pageant (1928. 78 days.)-Tall, sturdy plant with six to eight or more large beautiful flowers open at a time. Color a delicate rose pink ground flaked a rich, showy rose red. Deeper toward outer ends of petals. Throat lighter and lower petals a fine shade of yellow with very pretty pencilings. The colors harmonize so perfectly as to give the entire flower an almost self color effect. Very attractive and beautiful. Each, 25c. Doz., \$2.50. 100, $\$ 18.75$.

Palmetto (1929. 76 days.)-Tall fine plant with six to eight and more good sized flowers open at a time. Color of deep pure pink all over outside portion blending to a large white throat, whiter on lower petals. Center of lower petals have wide bars of red with narrow parallel pencil lines of same color. A distinct and showy pink Gladiolus. Each, 75c. Doz., \$7.50.

Pantheon (1922. 73 days.) - A large and massive waxy white on tall, strong plant. Lower petals beautifully penciled and feathered rose. Illustrated on page 40. Each, 10c. Doz., \$1.00. $100, \$ 7.50$.

Paramount (1918. 82 days.)-A wonderful blending of pink and cream. Similar to Mrs. Dr. Norton. Awarded first prize at Mid-western Gladiolus Show, Des Moines, Sept., 1925, for best light pink. Illustrated on page 52. Each, 35c. Doz., \$3.50. 100, \$26.25.

Pauline Kunderd (1926. 87 days.) - The new wonder Gladiolus. A pure rosepink of most fresh and delightful tone, with throat of finest cream in perfectly harmonious blending with. the pink. I do not believe there is a finer gladiolus in existence today. Destined to become famous. Illustrated on page 18. Each, $\$ 1.00$. Doz., $\$ 10.00$.

Philatelia (1927. 83 days.) - L a r g e, strong, vigorous plant. Flowers very large. Color deep tyrian-rose. Upper portion of throat lighter. Lower petals feathered darker than main color. One of the best gladioli produced in recent years. As a landscape and vase variety it would be very hard to surpass. Illustrated on page 87. Each, $\$ 1.00$. Doz., $\$ 10.00$.

Pink Delight (1928. 71 days.) -A strong, tall plant with many large and showy blooms, perfectly placed, open at a time. Flowers of good size, tubular in form, and of loveliest shade of soft, rich rose pink. Throat a delicate whitish cream and deeper soft yellow across middle of lower petals. Each, \$1.00. Doz., \$10.00.

Pink Beam (1928. 72 days.) - A tall, vigorous plant with plenty very large wide open flowers open at a time. Ground color beautiful blushed or flaked white. Upper and lower petals striped with a refined rose-pink. Central bars on lower petals have a long, narrow bar of deep, rich maroon penciled with narrower pencil lines of same color. Each, 35c. Doz., \$3.50. $100, \$ 26.25$.

Persepolis (1929. 81 days.) - Fine height and shapely plant. Six or more very perfectly placed blooms open at a time. Color a clean white ground over all the petals with a pure soft very delicate rose pink blush very evenly spread over the entire flower. Over all is again a very delicate shade of soft lavender. Throat has moderate blotches of deep purplish red beautifully feathered and penciled with same shade as ground color. Each, 75c. Doz., \$7.50.

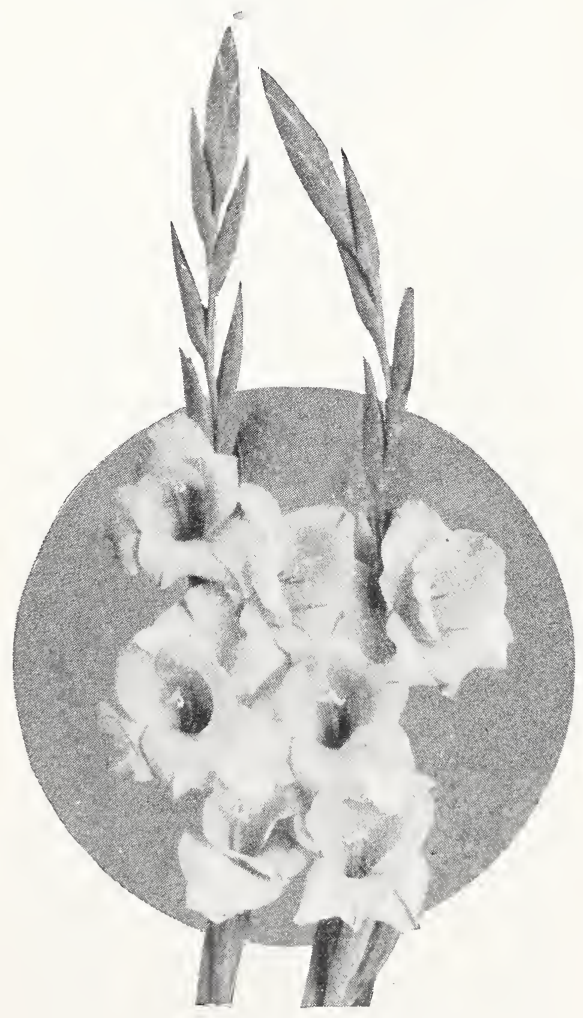

AH-Described on Page 48

A. E. Kunderd, Goshen, Indiana 


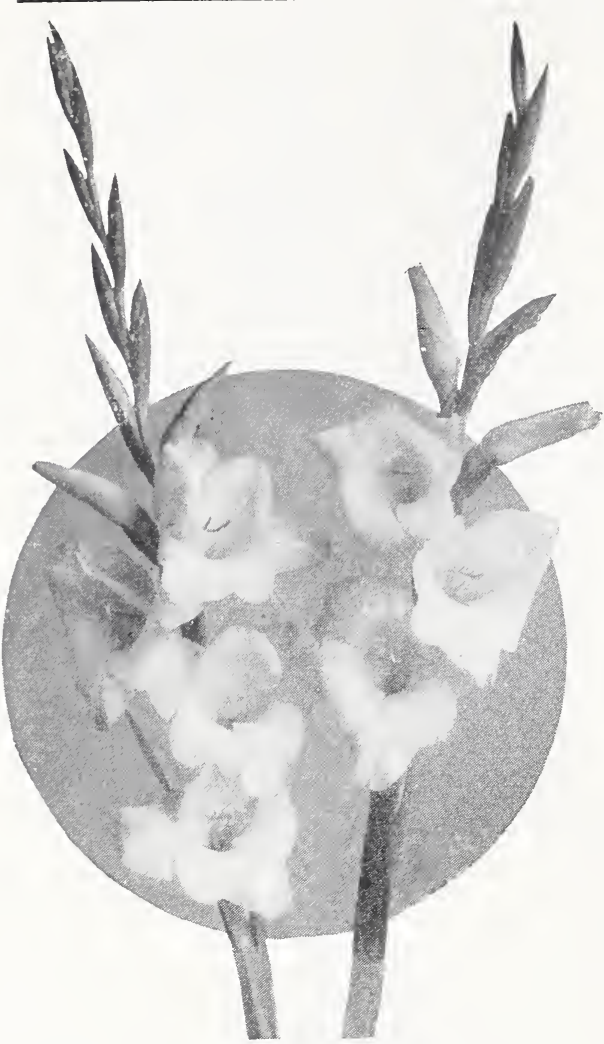

DR. J. H. NEELEY-Described on Page 55

Phillip Breitmeyer (1929. 73 days.)Tall fine plant with many large and beautifully placed flowers open at a time. Color a very rich rose pink with a delicate lavender tone over entire flower. Throat has wide dark red median lines with paralleled thread lines of same color on a whitish ground. A very choice and showy variety. Each, \$1.00. Doz., \$10.00.

Pink Pansy (1928. 83 days.)-An extra large, wide open, massive and showy flower on a fine plant. A deep orange red closely flaked on a lighter ground. Throat marvelously stippled on a beautiful creamy ground. Blotches narrowly bordered finest red and central bars of deeper cream or soft yellow, extending beyond the very showy pansy-like blotches. Each, $\$ \mathbf{1 . 0 0}$. Doz., $\$ 10.00$.

Pink Enchantor (1929. 80 days.)-Tall fine plant with five or more large flowers open at a time. Petals all widely expanded with upper one very upright giving the flowers a diamond shape. Color of the richest glowing rose pink imaginable. Lower throat portion deeper or rose red. A very beautiful variety. Each, \$2.00. Doz., $\$ 20.00$.

Planada (1929. 77 days.) - Tall strong plant with a very large showy flower of fine delicate rose pink color. Rich showy dark central bars paralleled in fine tracery of same color. A showy throat and a very fine pink variety. Each, 50c. Doz., \$5.00.

Polychrome (1928. 74 days.)-Good height plant with well shaped spike and medium large flowers. Color deep mahogany brown over entire six petals excepting a bright blotch of red on lower petals blending harmoniously with the ground color, and has a distinct, small median line of white. A decidedly unusual and showy flower. Each, 75c. Doz., \$7.50.

Pompeian Beauty (1927. 73 days.)-A very large flower, round in shape and wide open. Extra strong plant. Color a pleasing, deep rose-pink. Fine, large throat markings of red with neat white points extending through central lines on lower petals. Five and six perfect blooms open at a time. Lightly ruffled. Excellent bouquet and garden variety. Each, 35c. Dэz., \$3.50. 100, $\$ 26.25$.

Pond Lily (1929. 80 days.)-Fine height showy plant. Numerous quite large most beautiful deep rose pink flowers. Deeper in throat with still deeper central bars on lower petals. A very beautiful pure rich deep bright rose pink variety. Grand and beautiful. Each, \$2.00. Doz., \$20.00.

Predominator (1929. 86 days.)-Extremely tall, slender and graceful plant with five or more large widely opened flowers in bloom at a time. Color of richest salmon scarlet. Lower petals of same color but with a fine wide feather of a beautiful velvety deep red, with narrow creamy-white line extending from the red about onehalf inch. By far the tallest in a field of over 30,000 varieties. A very desirable garden and cut flower variety. Each, 75c. Doz., \$7.50.

Pres. Lincoln (1929. 83 days.)-Tall graceful plant. Good sized flowers of lavender blue ground color flaked lilac blue on three upper and central lower petals. Two lower side petals, all except a narrow border, are covered with a beautiful deep lilac purple blotch which again has a fine long arrow shaped blotch of white towards outer portion. This gives the flower a very showy and orchid like appearance. An extra fine and showv orchidlike blue. Illustrated on page 59. Each, $\$ 3.00$. Doz., \$30.00. 
Pretty Pink (1929. 85 days.) - Fine plant with large (five and more), very beautiful rose-pink colored blooms open at a time. Throat a little deeper on lower petals. Extra choice and fine. Scarce. Each, \$2.00. Doz., $\$ 20.00$.

Primrose Beauty (1918. 73 days.)-Tall, strong, very large, primrose-yellow. Extra. Awarded first prize, A. G. S. show, 1926 , as the best cream colored variety, also winner of many other awards. Each, 10c. Doz., \$1.00. 100, $\$ 7.50$.

Prof. C. S. Sargent (1927. 85 days.)Giant plant of striking appearance. Flowers large. Color clean white, slightly pink with very light crimson marking on lower petals. Of such unusual beauty that it is easy to predict great popularity for this kind. Named in honor of the great curator of Arnold Arboretum, Boston. Each, \$2.00. Doz., $\$ 20.00$.

Prof. E. H. Wilson (Quartinianus $\mathrm{Hy}$ brid.) (1929. 113 days.) - Giant plant. Large, massive flowers. Color a rich, pure orange-red. On lower petals a narrow central bar of deep dark-red. Many blooms open at a time. Very late variety. An immense show flower. Named in honor of the late horticultural explorer and the man who gave America the wonderful Regal Lily. Each, \$2.00. Doz., \$20.00.

Purple Challenge (1928. 83 days.) Tall, stately plant, perfectly formed with fine foliage. Flowers very large and of a very distinct, pure and showy, deep red purple. Far surpasses much similar varieties as Anna Eberius, Elkhart, Jacoba Van Beyren and similar kinds. A good plant and flower in every way. A rapid multiplier. No doubt among the very greatest. Each, \$2.00. Doz., $\$ 20.00$.

Purple Pansy (1915. 73 days.)-Tall, slender plant. Plenty of blooms open at a time. Richest deep-purple, fine pansy-like throat. A very favorable impression was made with my stunning basket of this variety used with Magic. This was one of the most artistic baskets at the A. G. S. show, 1926 , and was awarded an A. G. S. Trophy for the best funeral basket. Each, 20c. Doz., \$2.00. 100, \$15.00.

Purple Progress (1929. 72 days.)-Tall fine plant. Flowers much larger and showier than "Baron J. Hulot" and much finer in every way but almost of exactly the same color. Received a medal of The American Gladiolus Society for best new seedling. A grand "Baron J. Hulot" improved. Each, \$7.50.
Purple Spot (1918. 84 days.)-Large violet-red with very conspicuous dark blotches. Early, showy. Each, 10c. Doz., \$1.00. 100, \$7.50.

Quartin Dillon (1928. 104 days.)-Tall, strong plant with many large flowers open at a time and all facing perfectly one way. Color very dark mahogany brown red. Large throat blotches of a deep bluish red, edged rose red. Very rich and showy garden and show flower. Each, 25c. Doz., \$2.50. 100, $\$ 18.75$.

Queen of Orange (1929. 67 days.)Tall stately slender plant. Large round flowers of a brilliant orange red. Lower petals have five to seven narrow thread lines alternating red and yellow on a deeper orange red. Back of flowers nearly a pure self, but face of flower is finely traced all over with very fine pencilings of yellow. One of the most distinct and outstanding varieties. An extra showy landscape variety. Most showy at a little distance. Each, 50c. Doz., \$5.00.

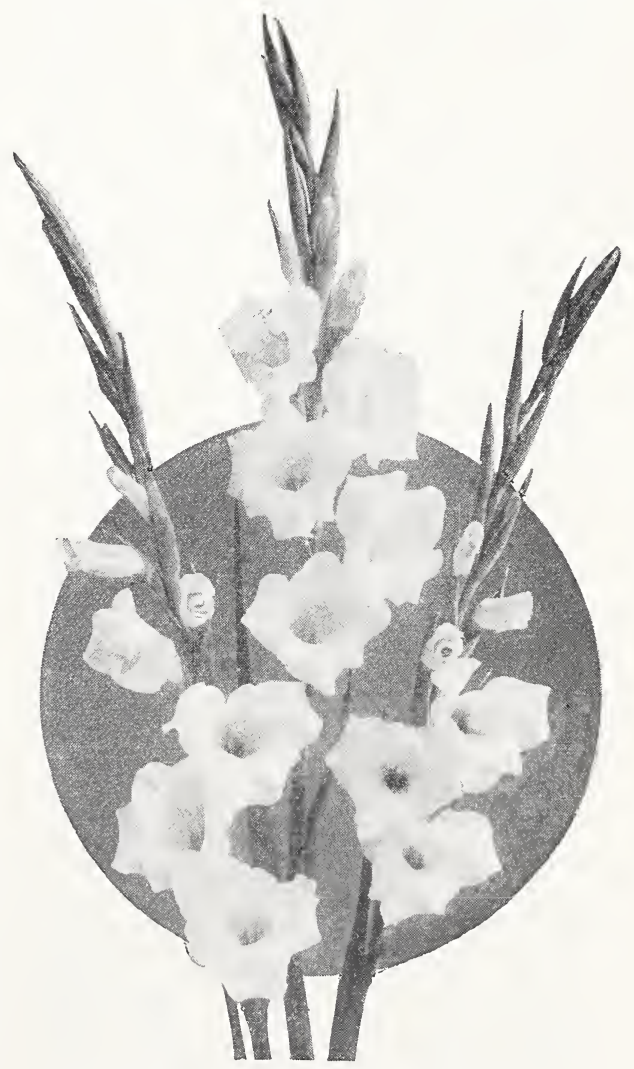

FAIREST WHITE-Described on Page 57 
Rajah (1917. 78 days.)-A well-known, very choice giant dark red. Awarded first price for best red without markings, at the A. G. S. show, Rochester, Aug., 1925. Again in 1926, this variety received first prize as the best dark-red variety, A. G. S. show. Illustrated on inside front cover. Each, 20c. Doz., \$2.00. 100, \$15.00.

Ravenna (1929. 73 days.) - Fine tall plant with large flowers of a very deep ruby red color. Throat a little deeper. Has a velvety sheen over all, especially rich on outside. Sometimes it has a slight white thread line down center of lower petals accentuating its beauty. A grand dark showy red gladiolus. Each, \$1.00. Doz., \$10.00.

Red Butterfly (1928. 92 days.)-Fine plant and flower. Bright rose red with beautiful, deep red throat blotches. These again have deeper, rich, velvety red median lines or midrib. A beautiful and showy variety. Each, 35c. Doz., \$3.50. 100, \$26.25.

Red Cardinal (1928. 72 days.)-Tall, stately plant with a long spike of blooms, beautifully and gracefully placed. Exceedingly showy blooms of indescribably beautiful, deep cardinal scarlet. Has a large, pure white throat with fine, deeper red central bars. Beautiful and distinct. Each, $\$ 1.00$. Doz., \$10.00.

Red Charm (1928. 80 days.) - Tall, fine and perfect plant with five and more large, showy, deep blood red flowers open at a time. The outer one-half of lower petals same rich red with deep, velvety, dark or blackish red throat blotches. A first class red. Each, 75c. Doz., \$7.50.

Red Cherry (1928. 83 days.)-Extra tall, graceful and slender plant. Flowers good sized and widely expanded. Color bright, rich red and deeper on lower petals. An extraordinarily fine plant and a rich, showy flower. Each, 20c, Doz., \$2.00. 100, \$15.00.

Red Cloud (1921. 84 days.)-Grand. Bright-red. Many flowers open. White bar in three lower petals. One of the most talked-of varieties at the Midwestern Gladiolus Show, Des Moines, Sept., 1925. Each, 15c. Doz., \$1.50. $100, \$ 11.25$.

Red Commander (1928. 99 days.)-Tall and very vigorous plant. Very large and massive flowers of deep, rich red. Faintly flaked deeper red on outer portion of all the petals and deeper red in throat. A giant and showy late red, an extra fine Quartinianus Hybrid. Each, 35c. Doz., \$3.50. 100, \$26.25.

Red Copper (1921. 80 days.)-Large flowers, deep salmon-rose, heavily flaked blue. Lower petals red, white and yellow, lined and penciled with blue. A choice, fancy color. Each, 10c. Doz., $\$ 1.00$. 100, $\$ 7.50$.

Red Darling (1929. 89 days.)-Neat medium sized plant and flower. Color a very pleasing, velvety dark cardinal red. Upper portion a little lighter in throat. Lower petals have large dark velvety blotches with still darker red median lines extending beyond the blotches. A very neat and attractive red with colors very prettily blended. A little beauty. Each, 35c. Doz., $\$ 3.50$.

Red Empire (1928. 95 days.)-Fine plant and very large flowers on a Princeps seedling, but with more flowers open at a time. Color a deep, cherry red, deeper in throat. A giant showy flower. An outstanding red. Each, 35c. Doz., \$3.50. 100, \$26.25.

Red Fire (1922. 80 days.) -A seedling of Princeps. Entire flower of richest, pure self-colored bright-red. Very striking and showy. Our best brightred gladiolus. Illustrated on page 51 . Each, 15c. Doz., \$1.50. 100, \$11.25.

Red Roamer (1928. 83 days.-Giant red variety of the Nanceianus form. Many flowers open at a time. Frequently laciniated. Very fine. Each, 75c.

Doz., \$7.50.

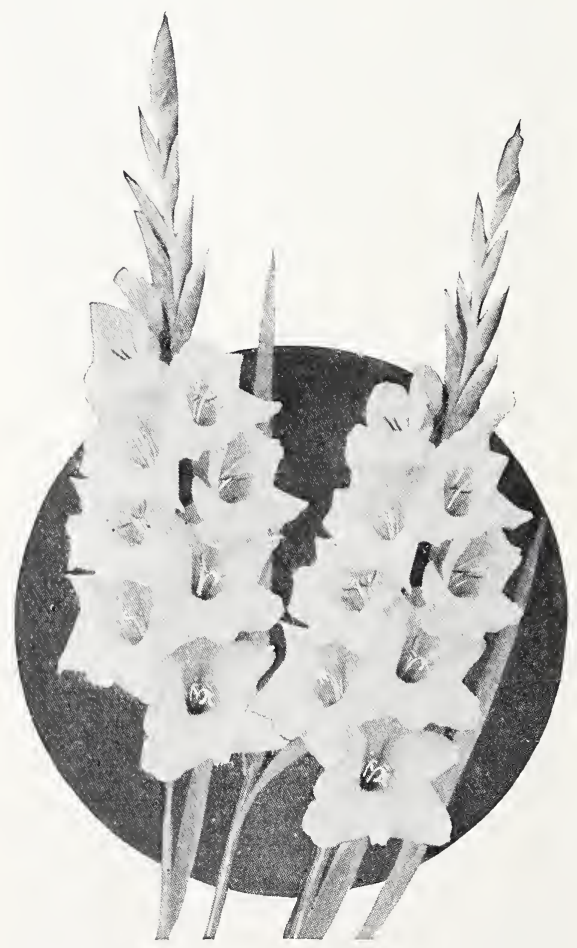

MARY PICKFORD-Described on Page 62 
Red Velvet (1927. 89 days.)-Deep-cardinal or blood-red. Delicately flaked deeper red. Throat bars are of darker red and pure white in narrow lines alternating beautifully. The most velvety as well as the most beautiful deep-red I have ever seen. A shade of red as beautiful as the famous cardinal flower or scarlet lobelia. Wonderfully beautiful. Each 75c. Doz., $\$ 7.50$.

Regulus (1929. 72 days.)-Another deep rose pink or rose red with dark carmine red throat blotches on lower petals. A narrow pinkish white pencil line extends outwards beyond the beautiful blotches. A decidedly rich and showy brilliant rose red. Beautiful. Each, 75c. Doz., \$7.50.

Remarkable (1927. 69 days.)-Very large, round blooms on strong spike. Vigorous plant. Color of a pleasing cherry-rose with entire lower petals deep rose-red, giving this variety a striking appearance. A marvel of beauty and one of the most outstanding garden varieties. Each, \$1.00. Doz., $\$ 10.00$.

Rhapsody (1929. 73 days.)-Tall neat plant. Numerous bright rose-pink flowers of pure self color effect with only a slightly deeper throat. Bright, showy and attractive. Each, 75c. Doz., $\$ 7.50$.

Robert J. Kunderd (1918. 80 days.)Medium tall, very large, most brilliant, deep-vermilion or orange-scarlet. A wonderful showy self-color. Illustrated on page 72. Each, 20c. Doz., \$2.00. 100, \$15.00.

Robinette (1929. 70 days.) - Plant medium height with large flowers, five or more open at a time, correctly placed and all facing one way. Color tyrian rose considerably lighter towards the throat and upper portion. Beautiful slight pencilings and veinings on lower petals. In all a very pleasing and attractive variety. Each, $\$ 1.00$. Doz., $\$ 10.00$.

Roman Candle (1929. 83 days.)-Tall fine beautiful plant. Color most beautiful pure soft self salmon red. Throat deeper. Very showy and grand. A color hard to describe but of the most beautiful shade imaginable. Each, $\$ 1.00$. Doz., $\$ 10.00$.

Romance (1918. 71 days.)-Large, orange, salmon, rose, red and yellow throat. Wine-blue bordered petals. Unusually distinct and very showy. Winner of two first prizes A. G. S. show, 1926. Illustrated on page 53. Each, 15c. Doz., \$1.50. 100, \$11.25.

Rose (1923. 77 days.)-Extra strong, large plant. Large, showy flowers of a pure, deep rose-pink color with large, be a utiful deep-red throat blotches. Very fine. Each, 25c. Doz., $\$ 2.50$. $100, \$ 18.75$.

Rosea (1928. 67 days.)-Good height and fine shaped plant. Flowers large and of fine form with five or more blooms open at a time. Color a deep salmon rose prettily flaked a pleasing shade of deeper rose. Throat stippled still deeper rose red on a white ground and outer portion of blotches terminating a fine white. The whole flower and spike of graceful appearance and regular in form. Each, 50c. Doz., $\$ 5.00$.

Rose Exquisite (1928. 72 days.)-Good, medium height. A fine, tubular bloom of a rich, deep rose pink color with a beautiful, rich, deep rose red blotch in throat. Flowers closely placed but in a neat, attractive arrangement. A beautiful garden or florists' flower. Each, 75c. Doz., \$7.50.

Rose Pearl (1928. 78 days.)-Tall, fine plant, large, wide open flowers beautifully placed. Color finest pure, deep rose pink imaginable. Throat a fine, deep rose stippled white in daintiest manner. Deeper narrow median lines. Color as fine as E. J. Shaylor. Illustrated on page 17. Each, 25c. Doz., $\$ 2.50$. 100, \$18.75.

Rosy Glow (1918. 83 days.)-Giant plant, massive flower of fine rose-pink on white ground. Very beautiful. Each, 15c. Doz., \$1.50. 100, \$11.25.

Rosy Smoke (1928. 84 days.)-Tall, extra vigorous plant with large, massive blooms and plenty open. Color deep salmon red flaked a deep smoky old rose. Base of throat beautifully striped red and white. Large wine blue throat blotches with very red central bars terminating white subdued under soft red. An extra showy variety in the richly or fancy colored class. Each, 50c. Doz., \$5.00.

Royal (1928. 86 days.)-Tall, fine plant with large, wide open, roundish flowers. Color dark, velvety red. Deeper throat edged brighter red. Petals flaked a deeper red. A choice, rich, showy red. Each, 50c. Doz., \$5.00.

Royal Purple (Quartinianus Hybrid) (1927. 101 days.) - A very large bloom of richest violet-purple, slightly red cast. The most beautiful variety known to me in this color. Strong plant, spike tall and slender, making it extra fine for cutting. In great favor at the A. G. S. shows in 1925 and 1926. Illustrated on page 60 . Each, 75c. Doz., \$7.50.

Ruth Field (1927. 77 days.)-Nice, graceful plant. Flowers neatly placed on spike. Color a delicate, lavender rose-pink over entire flower excepting 


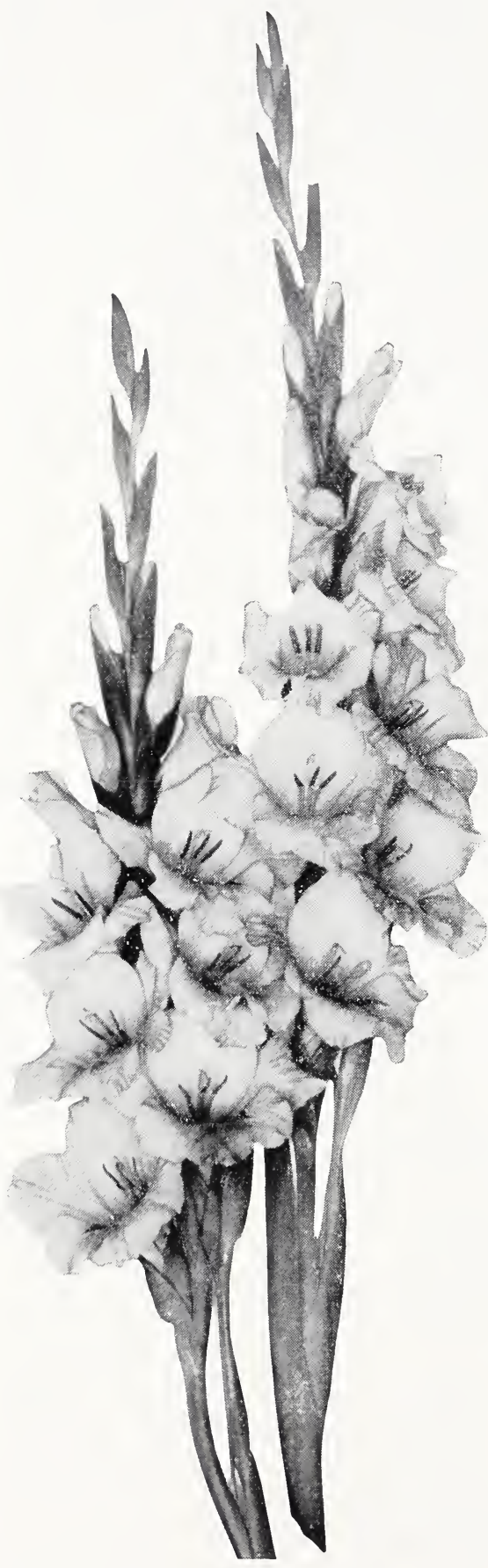

J. D. OLIVER-Described on Page 60 on inner half of lower petals, which are of a pure, soft cream color. No mottles or markings. A flower of very refined appearance. Each, 15c. Doz., $\$ 1.50$. 100, \$11.25.

Salmon Star (1928. 73 days.)-Tall, fine, shapely plant. Six or more good sized blooms open at a time. Color a decided soft self, deep salmon pink, of a mellow tint equal to the best pastel shade in this color. Throat a pure, soft canary yellow blending perfectly with the main color. An extremely beautiful variety. Each, \$1.00. Doz., $\$ 10.00$.

San Francisco (Quartinianus Hybrid) (1927. 89 days)-Large flower. Darkmaroon on wine color. Lower petals daintily penciled a light creamy-white. Self-color effect. Strong plant. Each, 35̃c. Doz., $\$ 3.50$.

Scarlet King (1929. 88 days.)-Good strong plant with a giant flower of a very intense scarlet. Unsurpassed by any other red. A wonderful red. Scarce. Each, \$3.00. Doz., \$30.00.

Scarlet Princeps* (1917. 74 days.)Six or more massive bright red blooms open at a time. Throat a little deeper. Blooms set close. An extraordinary, distinct and massive spike. Won a first prize at A. G. S. show, Rochester, Aug., 1925. Winner of many other awards. Each, 10c. Doz., \$1.00. 100, $\$ 7.50$.

Scarletta (1928. 67 days.)-Fine plant and a very beautiful flower of richest deep scarlet with a dainty and beautiful margin of old rose blue bordering all six petals. Lower petals with faint white lines terminating the narrow mid-rib. A rich, beautiful flower. Each, 20c. Doz., \$2.00. 100, \$15.00.

Show Flower (1923. 70 days.)-A giant flower of great attractiveness. All petals of fine shade of rose-red with immense white face, mottled deeper in throat. Violet and white upper throat. Very extra. Illustrated on page 41. Each, 20c. Doz., \$2.00. 100, $\$ 15.00$.

Snow Boy (1915. 76 days.)-Tall and stately; pure white. Many flowers open at a time. Often has only one beautiful blotch on lower petal. Large flower of finest form. Beautiful. Illustrated on page 55. Each, 15c. Doz., $\$ 1.50$. 100, \$11.25.

Snow Flake (1915. 71 days.)-A fine, all white, large flower on good plant, without any tint or markings. Awarded first prize for best pure white va-

* Scarlet Princeps has been unjustly renamed "Virginia" by some California parties. 
riety at A. G. S. show, Rochester, Aug., 1925. Each, 15c. Doz., \$1.50. $100, \$ 11.25$.

Spirit of ' 76 (1927. 83 days.)-Beautiful flower of deep vermilion-orange. Larger part of each lower petal covered with red lines interlaced with lines of white diverging from the center, giving the flower a decidedly attractive appearance. Artistic plant. Each, 35c. Doz., \$3.50. 100, \$26.25.

Splendor (1923. 68 days.) - A large, round flower of beautiful cardinal-red, approaching Lobelia in appearance. Very velvety, red. Each, 20c. Doz., $\$ 2.00$. $100, \$ 15.00$.

Splendorra (1916. 73 days.)-Splendid, very dark wine-black. A fine, rich, distinct sort. Illustrated on page 88 . Each, 10c. Doz., \$1.00。100, \$7.50。

St. Thomas (1923. 78 days.)-Very large plant. Immense, showy, deep, salmon rose-red blooms. Pure, selfcolor upper petals, lower petals wonderfully blotched with showier blotches than "Pendleton." Blotches dark-red with blackish central bars. Extra showy and grand. Each, 20c. Doz., $\$ 2.00$. $100, \$ 15.00$.

Sun Glow (1929. 80 days.) - A good height plant with very large flowers of purest self deep orange salmon color. Lower petals have a very fine red central bar with daintily penciled parallel lines and veinings of same color on a ground of beautiful golden yellow. On back of these flowers the yellow shown is a purest self which perfectly blends with the beautiful orange red ground color. Each, 75c. Doz., $\$ 7.50$.

Sweet Rose (1923. 76 days).-Very massive flowers on tall, strong plant, of purest deep rose-pink with extra large, beautiful red throat. A wonder rose-pink. In the rose-pink class at the 1926 A. G. S. show, first prize was awarded this variety. At the same show a basket of Sweet Rose was used in connection with a basket of Helga, Tiger, Dr. Nelson Shook and Kunderd's Yellow Wonder and took the Executive Committee's Silver Cup. Each, 35c. Doz., \$3.50.

Sylph (1929. 76 days.) - Tall fine plant. Color a brilliant flaming orange salmon, flaked deep orange red. Lower petals richest deep fiery orange red with beautiful narrow white central bars down the center of each petal. Exceedingly striking and showy variety. Each, $\$ 2.00$. Doz., $\$ 20.00$.

Taro (1921. 75 days.) - Large flowers on strong spikes. American Beauty rose-color. A new shade among gladioli. Each. 35c. Doz., \$3.50. 100, $\$ 26.25$.

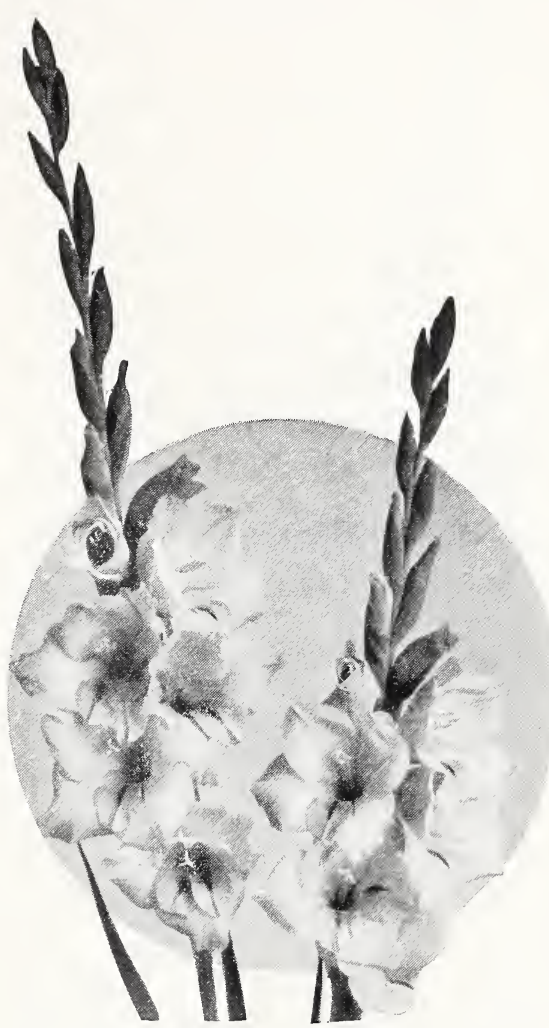

GOLDEN BUFF-Described, on Page 58

T. A. Weston (1928. 79 days.)-Tall, stately, showy plants. Flowers beautifully placed and very pleasing. Color purest deep salmon on rose pink. Throat a very beautiful soft canary yellow, very mellow and delicate. A refined and lovely flower in every way and for every purpose. Each, 75c. Doz., \$7.50.

Tiger (1926. 78 days.)-Mid-season. Tall, splendid plant with large, perfectly placed wide open flowers of remarkable tiger-like markings. Ground color of deep smoky-blue. Outer edges of petals of finest salmon-red flaking. Throat a beautiful red with outer portion of blotches white. Another of the sensations at the A. G. S. show, Rochester, Aug., 1925, and winner of a first prize. One of those unusual and very beautiful varieties which captivates at sight. A basket of this variety entered with a basket each of Dr. Nelson Shook, Sweet Rose, Helga, and Kunderd's Yellow Wonder won the Executive Committee's Silver Cup for the five best baskets of gladioli, A. G. S. National Show, 1926. 


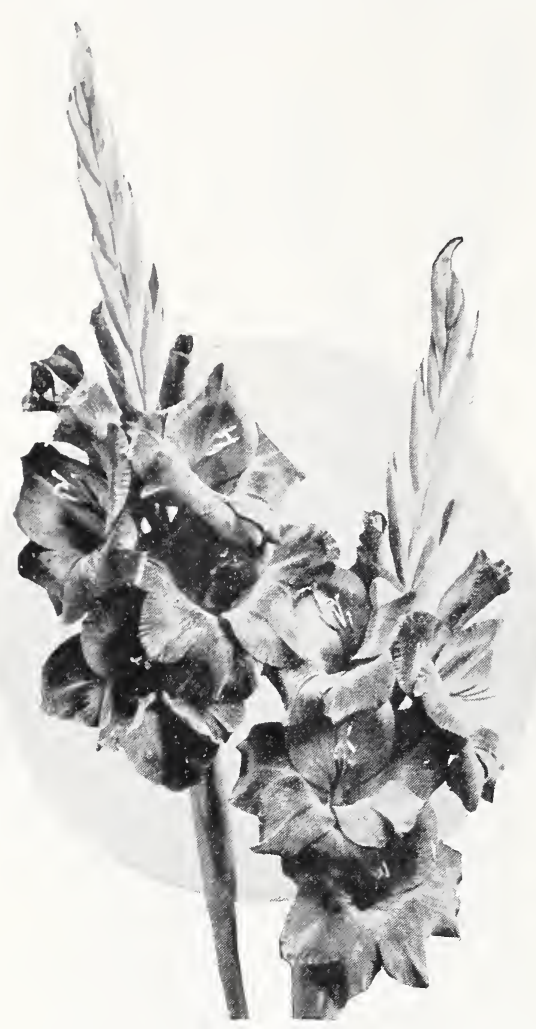

ROBERT J. KUNDERD-Described on Page 69

Illustrated on inside front cover. Each, 35c. Doz., \$3.50. 100, \$26.25.

Toledo (1929. 76 days.)-Tall strong vigorous plant with very large broad showy blooms all beautifully faced one way. Color of deep rich dark tyrian rose red. Large showy deep red crimson throat blotches. Very showy and choice variety. Each, $\$ \mathbf{1 . 0 0}$. Doz., $\$ 10.00$.

Tonopah (1928. 81 days.)-Tall, graceful plant with very large, wide open flowers. Color a deep tyrian rose pink and deeper in throat. A distinct and showy flower. Each, 25c. Doz., \$2.50. $100, \$ 18.75$.

Treasure (1923. 75 days.)-Tall plant. Large, round, wide open flowers of soft, salmon rose pink, flaked deeper rose, blended lighter towards the throat. A distinct and beautiful new variety. Each, 15c. Doz., \$1.50. 100, $\$ 11.25$.

Trianon (1929. 66 days.)-Tall fine shapely plant with large flowers beautifully placed. Color is a deep rich pure salmon pink with white central lines on three upper petals. Lower petals have almost crimson throat markings blending to delicate canary yellow covering most of the petals. A very delicately colored and beautiful variety. Each, 75c. Doz., \$7.50.

Tyrian Beauty (1918. 85 days.)-A beautiful, large flower near "American Beauty" rose color. Grand. Awarded first prize for best plain petaled variety at the Mid-western Gladiolus Show, Des Moines, Sept., 1925. Illustrated on page 87. Each, 15c. Doz., \$1.50.

Tyrian Rose (1928. 79 days.) - Tall, fine plant with plenty fine, large, bright tyrian rose colored blooms open at a time. Flowers finely expanded and perfectly placed on an ideal stem. Upper throat lighter, lower throat a deeper, rich, velvety dark red. Showy and fine in every way. Each, 75c. Doz., $\$ 7.50$.

Uhlan Chief (1922. 69 days.)-Tall, graceful, slender spike. Flower of most intense brilliant vermilion-scarlet. Lower petals deeper color and beautiful, dark feathered. A magnificent red. Each, 10c. Doz. \$1.00. 100, $\$ 7.50$.

Ulysses (1916. 80 days.)-Large, round flower. S mok y-blu e on rose-pink ground, deeper throat. Very attractive. Illustrated on page 56. Each, 15c. Doz., \$1.50. 100, \$11.25.

Velvet Diamond (1928. 79 days.)-Tall, stately, beautiful plant and spike. Flowers large, wide open, with upper central petal upright and curled back. All the petals are curled back and twisted much like a lily. Color richest, deep, velvety, blood red with a brighter shade of red down the center of each. No more beautiful and showy red can be imagined. Extra grand and beautiful. Each, \$2.00. Doz., \$20.00.

Vermilion (1928. 97 days.) - A fine plant with a beautiful, deep orange or vermilion scarlet flower and plenty open at a time. Large, pure white throat blotches with a dainty suffusion of softest canary yellow on outer portion. A very beautiful gladiolus. Each, 25c. Doz., \$2.50. 100, \$18.75.

Viola Gem (1928. 79 days.)-Tall and stately plant with an outstanding and beautiful deep, dark bluish green and perfect foliage. A good sized flower of a deep violet color and a dark, velvety red throat. An outstanding color in both flower and foliage, very distinct and fine. Each, 35c. Doz., \$3.50. $100, \$ 26.25$.

Violet Prince (1927. 73 days.)-Fine plant with flowers perfectly placed on spike. Color almost black violet-red. Pure self-color excepting that the throat is somewhat of a deeper shade of the same color. Six and more 


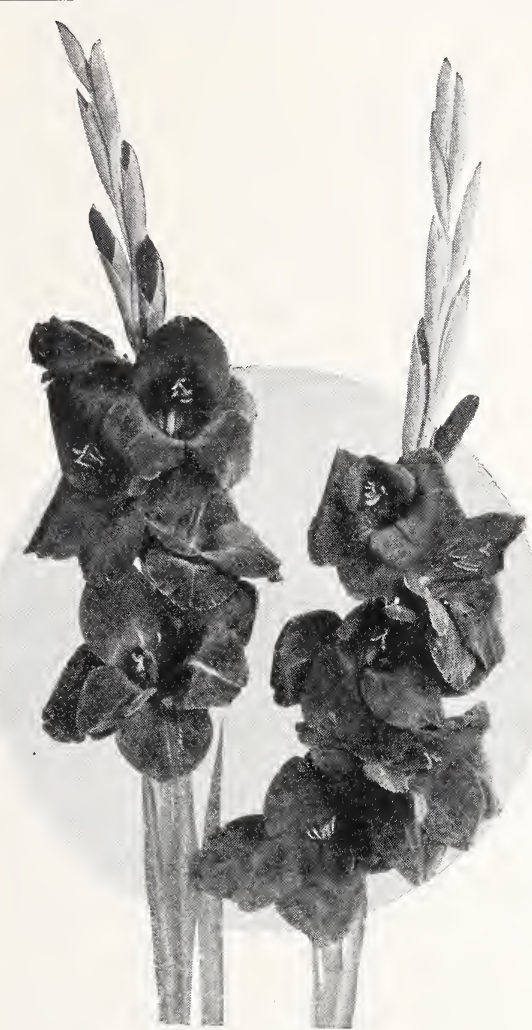

RED FIRE-Described on Page 68

blooms open at a time. An unusually fine, dark variety. Each, 35c. Doz., $\$ 3.50$. $100, \$ 26.25$.

Virginia Hale (1921. 84 days.)-Beautiful, soft creamy salmon-rose, deeper toward border of all petals. Very refined and beautiful variety. Each, 15c. Doz., \$1.50. 100, \$11.25.

Watermelon (1923. 75 days.) - Tall, fine plant. Large flowers, perfect form. Color a pure watermelon. As inviting and attractive as a beautiful watermelon. Unusually distinct and fine. Each, 20c. Doz., \$2.00. 100, \$15.00.

Wawasee (1927. 69 days.) - Very beautiful flower on fine spike. Color soft rose-pink, beautifully flaked all over with a clear, clean red. Elegant throat blotches of same color as the flakes but has deep crimson-red central bars veined white. A decidedly striking and beautiful garden and bouquet flower. Each, 25c. Doz., \$2.50. 100, $\$ 18.75$.

White Pigeon (1921. 70 days.)-Most wonderful, pure all white. Very large blooms, six to eight open. A strong, healthy grower and rapid propagator. Displayed in an unusually fine floral piece this variety was awarded first prize at the A. G. S. show, Rochester, Aug., 1925, A. G. S. bronze medal. In an equally beautiful double spray with "Peach Rose" was awarded another first prize, A. G. S. bronze medal. Winner of many other awards. Each, 20c. Doz., $\$ 2.00$. 100, $\$ 15.00$.

William Booth (1927. 78 days.)-Strong, massive plant. Very large flowers. Color a shade between tyrian-rose and rhodamine-purple. Lower petals of much deeper rhodamine-purple clear to edges. Central bars on lower petals still deeper. The most outstanding $\mathrm{gladiolus}$ of this shade. Each, 35c. Doz., \$3.50.

Wonderful (1927. 89 days.) - Of all my introductions for 1927 this is the most gigantic plant of all. Blooms of a deep rose-pink. Upper petals much lighter in throat and central white bars. Lower petals have large, showy dark-red blotches with deeper darkred bar in center, bordered white. Very attractive plant and flower. Splendid garden and cut flower variety. Don't miss this one. Each, 35c. Doz., \$3.50. $100, \$ 26.25$.

Grace L. Cody, Indiana. "My collection of Gladioli (31) have nearly all bloomed and they are sure fine. One large white and red one measures 64 in. and had 20 blooms on the first blooming stock and had three other stocks. My named variety was 'Pauline Kunderd.' It measures $50 \mathrm{in}$. and has 20 blooms on it. It is sure lovely."

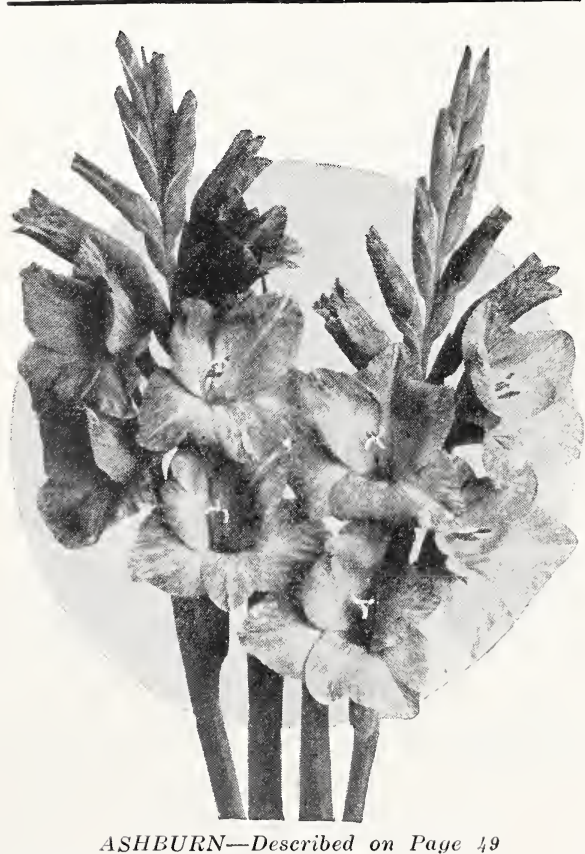

ASHBURN-Described on Page 49 


\section{Collection Offers \\ PLAIN PETALED VARIETIES}

These Collections Are All Sent with Each Variety Properly Labeled

Collection No. 34-All varieties valued at $10 \mathrm{c}, 30$ bulbs in all (value $\$ 3.00$ ) for.............\$2.70

Collection No. 35-All varieties valued at $15 \mathrm{c}, 35$ bulbs in all (value $\$ 5.25$ ) for.............\$4.75

Collection No. 36-All varieties valued up to and including 15c, 65 bulbs in all (value $\$ 8.25$ ) for.....\$7.45

Collection No. 37-All varieties valued up to and including 20c, 87 bulbs in all (value $\$ 12.65$ ) for.... \$11.40

Collection No. 38-All varieties valued up to and including 25c, 110 bulbs in all (value $\$ 18.40$ ) for... $\$ 16.55$

Collection No. 39-All varieties valued up to and including 35c, 144 bulbs in all (value $\$ 30.30$ ) for... \$ $\$ 25.75$

Collection No. 40-All varieties valued up to and including 50c, 162 bulbs in all (value $\$ 39.30$ ) for... \$ \$33.40

Collection No. 41-All varieties valued up to and including 75c, 190 bulbs in all (value $\$ 60.30$ ) for. . .\$51.25

Collection No.42-All varieties valued up to and including $\$ 1.00,215$ bulbs in all (value $\$ 85.30$ ) for ..................\$ \$72.50

Collection No.43-All varieties valued up to and including $\$ 2.00,237$ bulbs in all (value $\$ 129.30$ ) for

$\$ 109.90$

Collection No.44-All varieties valued up to and including $\$ 3.00,241$ bulbs in all (value $\$ 141.30$ ) for ......................\$120.10

Collection No.45-All varieties valued up to and including $\$ 5.00,245$ bulbs in all (value $\$ 161.30$ ) for ......................\$137.10

Collection No.46-Entire collection, one each of 246 varieties listed (value $\$ 168.80$ ) for........ \$143.50

Varieties Included in These Collections Are Listed on Pages 48 to 73

Take Advantage of My Offer for Early Orders-See Page 12 


\section{Introductions}

In this combined group are found the latest of my Primulinus Hybrids, new introductions of those rare and exquisite varieties, that have become so overwhelmingly popular because of their graceful appearance and delicate pastel shades. I regard the Primulinus as the finest of all gladioli. Their adaptability for table, basket and bouquet work is simply wonderful. They are beautiful flowers and you will tove them. They rival the orchid.

Oh Promise Me (1930. 60 days)-Very tall and stately plant with lovely "Prim." flowers. Spaced openly on spikes giving the effect of beautiful butterflies, airily poised on the stems. Widely expanded and open. Color and upper petals of richest flesh tone, deepening towards the edges. Lower a pure, clear delicate cream with ends of same color as upper petals. Six or more of these daintily colored and beautiful butterfly like flowers open at a time. Hardly surpassed by any other "Prim." hybrid in color or artistic beauty. Specially fine for corsages and brides bouquets. Each, \$2.00. Doz., $\$ 20.00$.

Orange Giant (1931)-Tall, strong sturdy plant with giant "Grandiffora Prim." flowers. Three to five open at a time. Color most intense pure deep fiery orange over all petals. Inner portion of throat on lower petals of deep fiery orange red. A mammoth and altogether outstanding rich orange color. Unusually distinct and showy. Very extra in this class. Each, \$1.00. Doz., $\$ 10.00$.

Ora n g e Salmon (1931)-Tall slender graceful stem. Flowers medium size of very distinct Primulinus form and color of a glowing orange with clean clear, large rich pure yellow throat. One of the best of all Primulinus varieties. Each, 50c. Doz., \$5.00.

Phyllis Cloetingh (1930. 64 days.)-Tall stately plant and good sized well open flower for a Primulinus Hybrid. Color of clearest salmon rose over entire six petals excepting a large throat of a soft canary-cream with central bars of a lighter yellow extending beyond the blotches. A decidedly distinct, lovely and beautiful flower. Each, \$1.00. Doz., $\$ 10.00$.
Prim gold (R-1930. 72 days.)-Tall, graceful, slender plant, with many good sized flowers open at a time. Color of upper petals rich canary yellow self. Lower petals deep golden daffodil yellow with long, beautiful red central bars. The whole flower is intensely ruffled and of a decidedly rich and beautiful appearance. One of those not very large but elegant and beautiful flowers which easily charm equal to those boasted large flowered beauties. Each, \$1.00. Doz., \$10.00.

Wonderland (1930. 78 days.) - A very tall and showy plant with very large Prim. Hybrid flowers of richest orange color. Fine large mellow deep orange red throat which has a slight and subdued soft primrose yellow central line extending down the center. A giant, showy and fine Primulinus $\mathrm{Hy}-$ brid of striking appearance. A rich and rare color among Gladioli. Each, $\$ 1.00$. Doz., $\$ 10.00$.

Yellow Frills (R-1930. 83 days.)-Tall, slender, graceful plant with plenty of large flowers in bloom at a time. Flowers widely opened and not hooded. Color, rich, clear, deep canary yellow all over, only slightly deeper on lower petals. Splendidly ruffled. Ideal in type, color and in every way a beauty. Extra fine. Each, \$1.00. Doz., \$10.00.

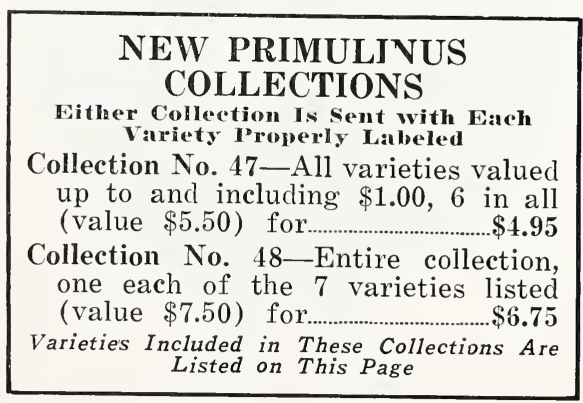


The race of Primulinus as a whole is regarded universally with great favor. Its sudden rise to popularity is phenomenal. Few flowers have risen from obscurity into prominence as rapidly as have Primulinus and I am of the firm belief that their greatest prominence is still far off. These unusually fine Gladioli are destined to become favorites. The spikes are very graceful and blossoms are airily poised upon them. The colors which are mostly of pastel shades are so perfect and so vivid that one must see them to appreciate them. For home use they are unsurpassed. At bridge luncheons and parties of every kind the Primulinus Hybrids are very much desired. Be sure to include them in sufficient numbers.

Alice Tiplady (1915. 72 days.) - A grand, large Primulinus of most beautiful orange-saffron color. Was awarded First-class Certificate of Merit by the North Shore Horticultural Society, Manchester, Mass., Summer of 1919. Winner of hundreds of awards. Very choice. Each, 10c. Doz., \$1.00. 100, \$7.50.

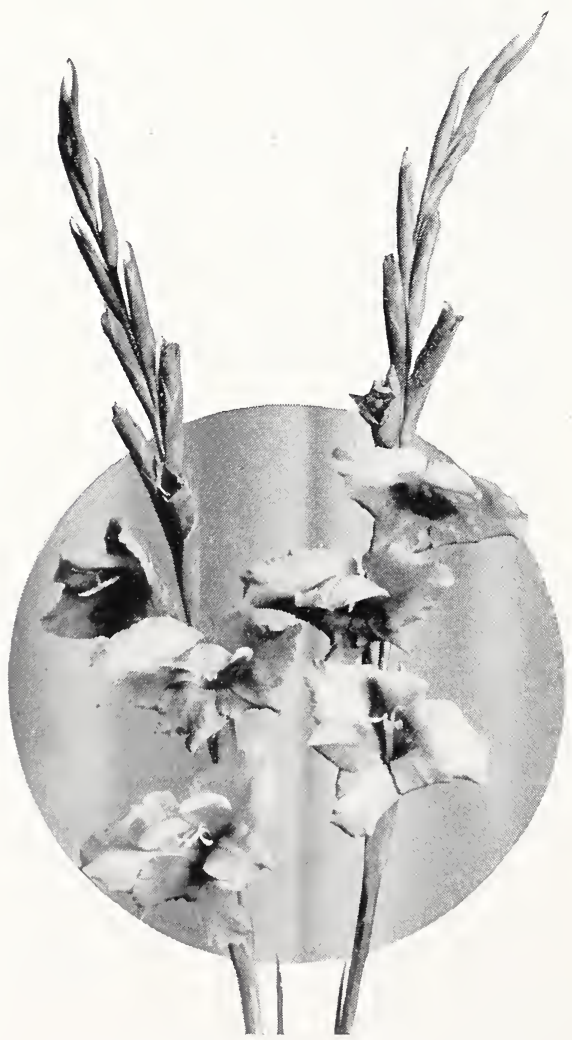

ENCORE-Described on Opposite Page
Altair (1916. 64 days.)-Extra tall, of finest salmon-saffron. A grand color. At the A. G. S. show, Rochester, N. Y., this variety won the A. G. S. Trophy for best corsage bouquet, also Trophy for best Plateau Basket. Winner of many other awards. Each, 10c. Doz., $\$ 1.00$. 100, $\$ 7.50$.

Athene (1925. 86 days.)-Fine, salmon rose-red. A very beautiful and distinct variety. Each, 15c. Doz., \$1.50. 100, $\$ 11.25$.

Butterboy (1922. 66 days.)-An extra tall, strong plant and giant bulb. Large buttercup-yellow flowers, nicely spaced on spike. A decidedly distinct and showy Primulinus variety of much merit. This variety won first prize at A. G. S. show at Rochester, 1926, for best yellow. Each, 15c. Doz., \$1.50. $100, \$ 11.25$.

Butterfly (1915. 76 days.)-Very strong and vigorous. Large, pale, salmonyellow, ruffled flowers. Winner of many awards. Each, 10c. Doz., \$1.00. 100, $\$ 7.50$.

Cassiopia (1925. 67 days.) - Dainty salmon-pink. Lower petals dainty cream blended. Refined and beautiful. Each, 15c. Doz., \$1.50. 100, $\$ 11.25$.

Copper Bronze (1925. 74 days.)-A very striking copper bronze color. Very large flowers. Graceful in appearance as a vase flower. Strikingly unusual. Each, 35c. Doz., \$3.50. 100, \$26.25.

Cygnus (R-1925. 68 days.)-Beautiful salmon-apricot. Lower petals softest daffodil-yellow with fine pink throat lines. A large, very choice, delicate and refined Primulinus variety. Each, 15c. Doz., \$1.50. 100, $\$ 11.25$.

Dainty Orange (1928. 72 days.)-Tall, slender, graceful spike with many small to medium sized flowers open at a time. Flowers perfectly placed and slightly spaced giving spikes a decided and attractive appearance. Ends of all

See Special Collection Offers, Pages 15, 21, 30, 35, 47, 74, 75, 81, 83 
petals of bright, light orange color while upper throat and back of petals is of a very rich, deep orange color. The whole flower is a beautiful glowing orange in effect and very beautiful on the plant or in floral work. Each, 50c. Doz., $\$ 5.00$.

Enchantress (R-1926. 75 days.) - A Grandiflora Primulinus. Medium large flowers of daintiest, soft shrimp-pink. Throat of faintest, soft cream-white, slightly penciled pink. A most excellent variety. Each, 25c. Doz., \$2.50. $100, \$ 18.75$.

Encore (1929. 58 days.)-Good height plant with very beautiful canary yellow upper petals, and lower petals of purest daffodil yellow over almost entire petals excepting lighter towards the ends. Illustrated on opposite page. Each, 50c. Doz., \$5.00.

Evening (R-1927. 69 days.)-Grandiflora Primulinus - Tall, slender, graceful plant. Five to six very dainty, soft flesh-pink colored blooms open at a time. Throat a very dainty, soft canary-yellow of purest tint. Exceedingly fine. Each, 35c. Doz., \$3.50. 100, $\$ 26.25$.

Golden Frills (R-1925. 66 days.)-A large and open flower. Deep, rich daffodil-yellow with slight pink lines on lower petals. Intensely ruffled and very choice. Beautiful tips of this variety arranged in a bowl and shown at the A. G. S. show, Rochester, Aug., 1925, awarded first prize for "best display of gladiolus tips in bowl," A. G. S. Trophy. Each, 50c. Doz., \$5.00.

Golden Gleam (1922. 74 days.)-Tall, very large and open Primulinus of lighter shade than "Alice Tiplady." More orange color. Extra. Each, 10c. Doz., $\$ 1.00$. 100, $\$ 7.50$.

Golden Harmony (1928. 69 days.)-Tall, slender, graceful spike with many very neat ruffled blooms open at a time prettily placed. Color of upper petals fine canary yellow. Lower petals deeper rich canary or daffodil yellow with deeper central golden narrow bars. Each, 35c. Doz., \$3.50. 100, \$26.25.

Golden Light (1928. 71 days.)-Fine, handsome spike with very large flowers. Color a soft, deep sulphur yellow upper petals; lower petals a very rich deeper yellow. The two colors very perfectly blended. A first class florists' variety as well as a very fine garden flower. Each, 50c. Doz., \$5.00.

Golden Arc (1928. 72 days.)-Fine, medium height plant with four and more grand, large, beautiful, light orange colored flowers open at a time. Lower petals a deep, pure, golden daffodil yellow except ends which are the same color as upper petals. The whole effect is a rich, golden orange. Extra grand. Each, 75c. Doz., \$7.50.

Golden Orange (1927. 67 days.-Grandiflora Primulinus) - The name describes it. Tall, fine spike with beautifully formed flowers of good size. Perfectly placed on spike. Color of a beautiful golden or soft orange tone. Self-color. Back of flower deeper shade of same color. Almost like gold. Extremeìy rich and beautiful. Each, 75c. Doz., $\$ 7.50$.

Golden Tinge (1923. 70 days.)-Fine stem and plant. Very dainty, orangesalmon flowers, deepening toward ends of petals. Lower petals deep-yellow with beautiful golden throat lines. A very beautiful throat and a grand variety in every way. This variety displayed in a basket with "White Butterfly" at the A. G. S. show, Rochester, Aug., 1925, won first prize, A. G. S. bronze medal. Each, 10c. Doz., \$1.00. $100, \$ 7.50$.

Golden Victor (1928. 66 days.)-Tall, graceful, perfect plant. Color pure, self, deep yellow, deeper than "Souvenir." Flowers perfectly placed and all facing one way, with many open at a time. I believe this is the finest and deepest pure yellow Primulinus Hybrid to date. Each, 75c. Doz., \$7.50.

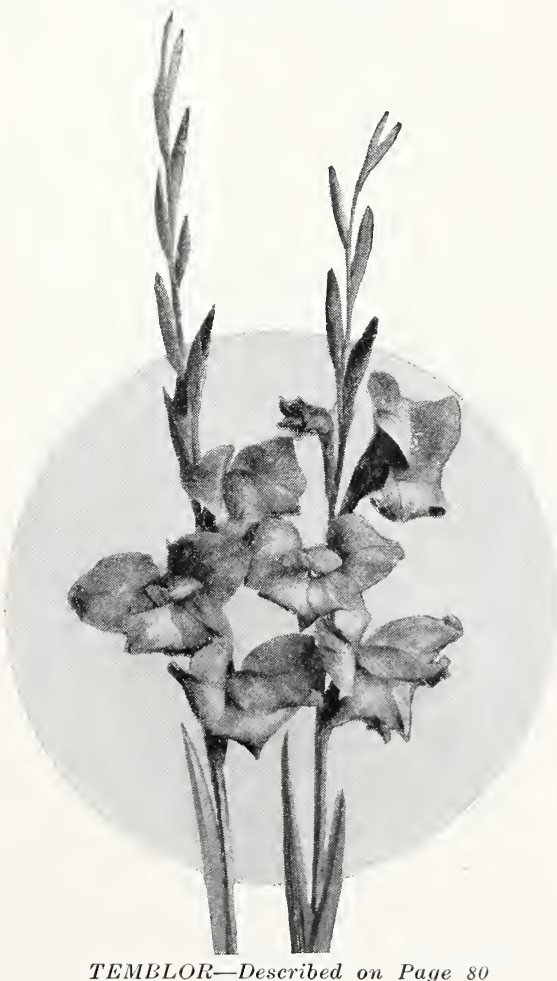

TEMBLOR-Described on Page 80 


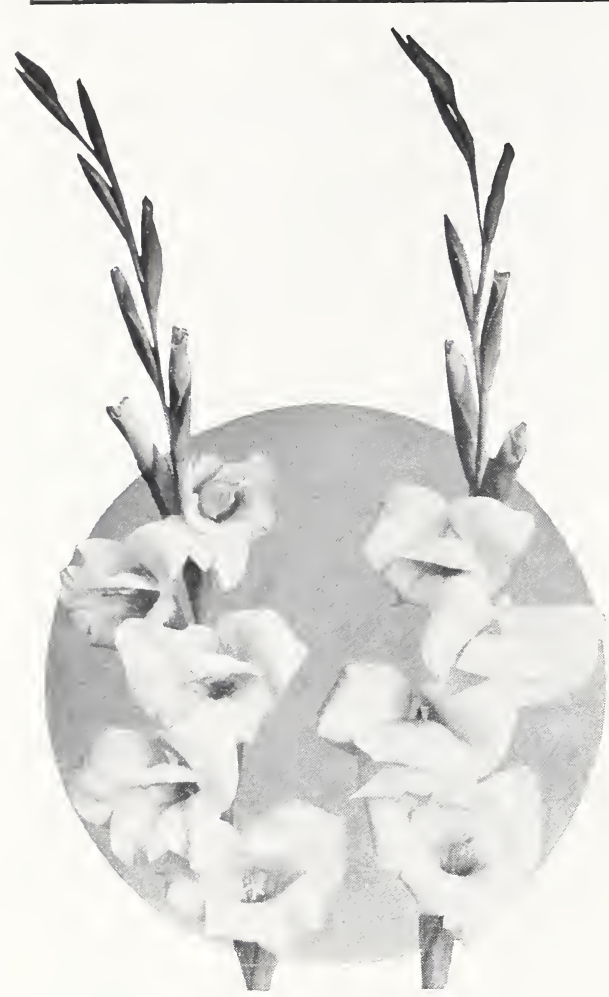

WHITE BUTTERFLY-Described on Page 81

Hoosier Pearl (1927. 69 days.) - A superb variety. (Grandiflora Primulinus) Tall, fine plant, flowers medium size, perfectly placed. Throat purest, soft pastel-yellow on lower petals, blushed pink toward outer edges. Upper petals dainty pink. The entire effect is dainty apricot making it a very pleasing variety. Increases fast and makes two and more spikes from each bulb. An outstanding gladiolus which will no doubt become very popular. Stock yet very small. Each, 35c. Doz., \$3.50.

Jap (1927. 67 days.) - A large, fine shaped bloom on fine spike of good height. Flowers well expanded and beautifully placed on spike. Color a most refined and beautiful tone of lemon-yellow. Self-color. Must be seen to be appreciated. (Grandiflora Primulinus). Each, 35c. Doz., \$3.50. 100, $\$ 26.25$.

King of Oranges (1927. 79 days.) - A large showy Grandiflora Primulinus variety of an intense deep orangesaffron color. Much like the popular variety, Alice Tiplady, but much deeper color and finer. Sure to become a winner. Illustrated on page 18. Each, 35c. Doz., \$3.50. 100, $\$ 26.25$.
Leen Wone (1927. 62 days.)-(Grandiflora Primulinus)-An extraordinary, pure, deep, self-colored orange. Five or more perfectly shaped blooms open at a time. Medium sized flowers. Very lasting as a cut flower. Nothing so fine in pure orange color has ever been placed on sale. Small stock. Each, 20c. Doz., $\$ 2.00$. 100, $\$ 15.00$.

Lorraine Cloetingh (1928. 74 days.)Fine, slender graceful plant. A very large medium ruffled Primulinus $\mathrm{Hy}$ brid. Most beautiful flesh pink outer half of petals. Inner half a softer flesh pink. Throat of daintiest pearly cream perfectly clear down to base of flower. One of the daintiest and most beautiful flowers imaginable. Each, 75c. Doz., \$7.50.

Lullaby (1928. 66 days.) - A light orange yellow with a wider border of deeper orange red on ends of all the petals. Throat a deeper yellow than the upper petals. Very pleasing and attractive. Each, 50c. Doz., \$5.00.

Marigold (1926. 80 days.)-Midseason. A giant Grandiflora Primulinus of most beautiful, deep canary-yellow. Lower petals deeper with slight pencilings. Flowers very large and widely open. Lightly ruffled. One of the most striking and beautiful Primulinus yet produced. Illustrated on inside back cover. Each, 35c. Doz., \$3.50. 100, $\$ 26.25$.

Melody (1928. 69 days.)-Fine, light and graceful plant with large Primulinus flowers of a rich lemon yellow. Enc's of all six petals beautifully bordered a delicate orange red. A very effective variety. Each, 35c. Doz., \$3.50.

Midsummer Dream (1918. 72 days.)-A large, beautiful geranium red. Showy, fine. This variety won first prize as the best dark Primulinus at A. G. S. show, 1926. Each, 15c. Doz., \$1.50. $100, \$ 11.25$.

Ming Toy (1922. 71 days.) - Very large flower of finest form. Showy, deep buff-yellow throat. Tall plant. A sensation at the North Shore Horticultural Show at Lake Forest, Ill. This variety, combined with Golden Frills, was awarded the A. G. S. Trophy for the best hamper of Gladioli at A. G. S. show, Aug., 1926. Also winner of many other awards. Each, 15c. Doz., $\$ 1.50$. 100, \$11.25.

Mongolia (1928. 74 days.)-Very tall, stately plant. Large Primulinus $\mathrm{Hy}-$ brid with flowers perfectly placed and beautifully spaced. Color of intense daffodil yellow, a little deeper in throat 
but as near a perfect self as any. Five or more very large (for a Primulinus) flowers open at a time. I believe this is the deepest yellow and finest yellow Primulinus Hybrid to date and no doubt will become very popular both as a garden favorite and a florists' flower. Each, 50c. Doz., \$5.00.

Mrs. Calvin Coolidge (1927. 66 days.)A superb Grandiflora Primulinus. Fine plant and large flowers. Color of finest deep flesh or salmon rose pink. Lower petals of a soft creamy-yellow tint, bordered same shade of pink as the upper petals. Border of all petals has a very slight white line adding materially to its attractiveness. Unsurpassed in its class. Named by special permission from President Coolidge. This beautiful new introduction won an A. G. S. award of merit as the best new seedling variety in the Primulinus Grandiflora class at A. G. S. show, Rochester, 1926, and easily won as the most outstanding variety at the A. G. S. show, Toledo 1928. Each, \$1.00. Doz., $\$ 10.00$.

Opal (1925. 69 days.)-Large flower of beautiful salmon-pink shade. Lower petals, deep, soft daffodil-yellow. Beautiful and dainty. Each, 15c. Doz., \$1.50. $100, \$ 11.25$.

Ozone (1923. 72 days.)-Tall plant and fine spike with a good number of blooms open at a time. Flowers of purest, deep canary-cream color. Entire lower petals covered with purest deep apricot cream. An exceedingly pure, finely colored variety which must be seen to be appreciated. Each, 15c. Doz., \$1.50. 100, \$11.25.

Paladin (1928. 72 days.-Tall, stately plant with a refined, small and dainty flower intensely ruffled and beautifully placed. Color soft, creamy white with lower petals a fine deeper cream and slight central pink line pencilings. Very dainty, neat and pretty. Each, 3äc. Doz., \$3.50. 100, \$26.25.

Pasteline (1928. 71 days.) -Tall, elegant plant and foliage. Four to six beautifully placed, good sized blooms open at a time. Color, upper petals a decidedly deep, soft creamy yellow. Lower petals a beautiful golden yellow as fine as the finest daffodil. An extra fine Primulinus Hybrid. Each, 25c. Doz., \$2.50. 100, $\$ 18.75$.

Polyhymmia (1929. 79 days.) - Very tall, slender plant of purest white clear down into throat. No flaking and no blotch but daintily blushed purest soft pink on outer portion of petals blend- ing wonderfully to purest white towards the throat. None more dainty and refined. Each, 50c. Doz., \$5.00.

Patricia Carter (1926. 71 days.) -(Primulinus Grandiflora.) Tall, fine plant, rugged in its growth and beautiful. Tall spike with five and six perfectly placed flowers open at a time. Large bulbs average three and four spikes. Flowers are of most beautiful tone of softest, light shrimp-pink color. No markings. The most beautiful Primulinus I have ever offered to my customers and one which is destined to become very popular. Named in honor of the little granddaughter of Dr. F. E. Bennett, so widely known among lovers of the gladiolus and one of the world's largest amateur gladioli growers. Illustrated below. Each, 75c. Doz., $\$ 7.50$.

Ramona (R-1918. 75 days.)-Dainty yellow. Golden throat. Beautifully ruffled. Each, 10c. Doz., \$1.00. 100, \$7.50.

Red Orange (1929. 76 days.) - Tall strong graceful plant, a grand, showy giant Primulinus. Color a deep orange red with beautiful central bars of deeper

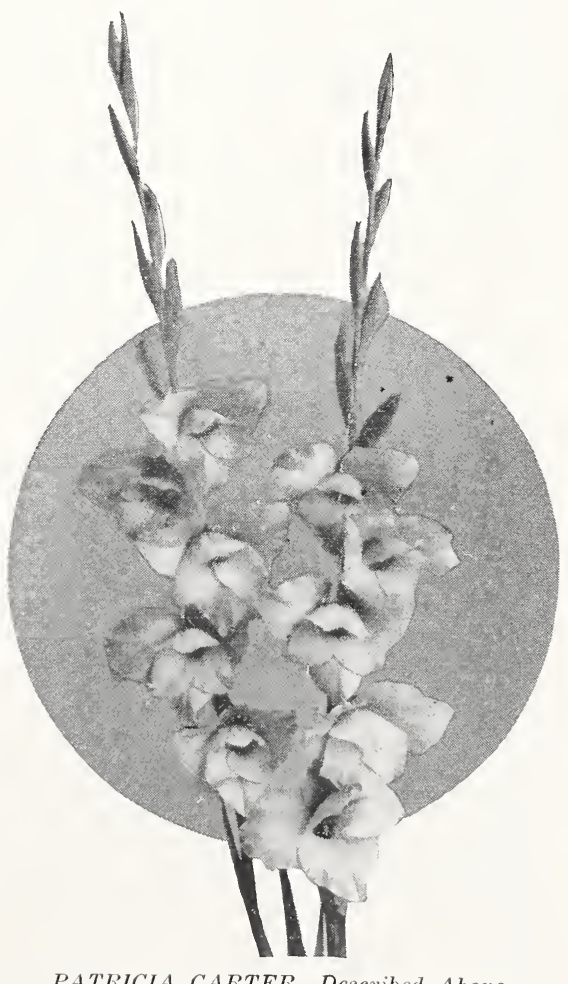

PATRICIA CARTER-Described Above 
red, elegantly penciled on a beautiful soft yellow ground. Very beautiful for basket and all kinds of decorative work. Each, 75c. Doz., \$7.50.

Saffron King (1928. 76 days.) - A very large Primulinus Hybrid of a rich saffron orange color beautifully flaked a deeper orange, rich golden yellow with clear throat blotches of beautiful form and in perfect contrast with the main color. A decidedly fine orange Primulinus Hybrid and very showy and beautiful. Each, 50c. Doz., \$5.00.

Salmon Buff (1922. 88 days.) - A good height spike with very large flowers of beautiful salmon-buff. Throat fine yellow, beautifully penciled. Each, 10c. Doz., \$1.00. 100, \$7.50.

Shell Pink (1921. 73 days.) - Tall, largeflowered, rose-pink with b e a t if u l slightly mottled white throat. Very choice. Winner of many awards. Illustrated on page 17. Each, 10c. Doz., $\$ 1.00$. 100, $\$ 7.50$.

Stippled Beauty (1928. 66 days.)-Tall, graceful plant. Large and showy flower of beautiful, deep, salmon rose pink flaked a deeper rose red shade. Lower petals, all but ends, very beautifully penciled. Stippled a beautiful yellow and red. A very showy and beautiful Primulinus Hybrid. Each, 20c. Doz., \$2.00. 100, $\$ 15.00$.

Sweeter Seventeen (1927. 85 days.)(Grandiflora Primulinus)-Large flowers on tall strong plant. Distinct in appearance. Cleanest, clear, deep salmonpink. Throat, dainty pastel-yellow. Lower petals creamy-yellow; excepting at edges it is salmon pink as upper petals. Excellent spike for cutting and otherwise very fine. Each, 75c. Doz., \$7.50.

Syncopation (1928. 72 days.)-L a r g e Primulinus on a tall, fine plant. Flowers beautifully placed and intensely ruffled. Broad, widle open upper petals and light lemon in color. Lower petals deepest canary or deep daffodil golden yellow with a beautiful narrow pencil line of red on midrib or central bar's. Each, 25c. Doz., \$2.50. 100, \$18.75.

Taurus (1925. 67 days.) - A beautiful Primulinus Hybrid of a fine purple or purple-violet color. Distinct, rare and fine. Displayed in a beautifully arranged basket with "White Butterfly" at A. G. S. show, Rochester, Aug., 1925, won first prize, A. G. S. bronze medal. Each, 15c. Doz., \$1.50. 100, \$11.25.

Temblor (1926. 73 days.) - A g i a $n t$ Grandiflora Primulinus. Tall, graceful

See Special Collection Offers, Pages spike. Five and six blooms open at a time. Color wonderful, clear salmonred, deeper towards outer edge of petals. Throat of purest, soft creamywhite. Elegant. Illustrated on page 77. Each, 25c. Doz., \$2.50. 100, \$18.75.

Today (1926. 77 days.)-A Grandiflora Primulinus. Large flower of grandest salmon-orange. Throat dainty, soft yellow. Flowers beautifully opened with petals recurved as elegantly as a very beautiful lily. Each, 20c. Doz., $\$ 2.00$. 100, $\$ 15.00$.

Ulrica (R-1918. 80 days.)-A wonderfully choice, rich yellow overspread lightly orange. Large flowers and very attractive. Each, 10c. Doz., \$1.00. 100, $\$ 7.50$.

Varro (1929. 69 days.)-Tall slender graceful plant with medium size flowers very beautifully spaced on the spike. Main color is a soft old rose tint slightly lavender. Throat is a beautiful cream with very narrow pencil line through center. A very refined and showy flower. Each, 35c. Doz., $\$ 3.50$.

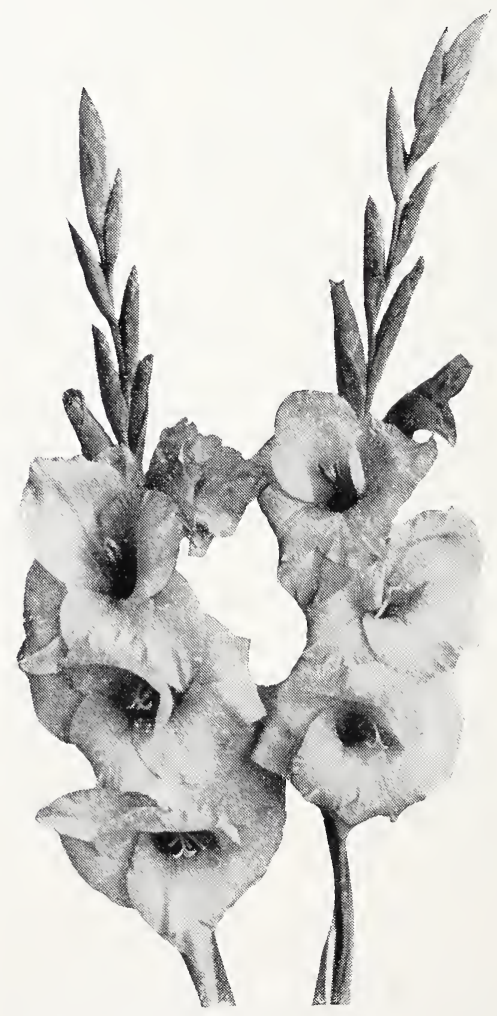

MARIGOLD-Described on Page is 
Virginia Lou (1926. 78 days.)-Mid-season. A giant Grandiflora Primulinus. A widely open flower of large size. Color rich, old-rose pink, throat of daintiest, creamy-yellow with slight pink pencilings deep in throat. An extra grand and beautiful cut flower variety. Each, 20c. Doz.,. \$2.00. 100, $\$ 15.00$.

White Butterfly (1922. 70 days.) - A first-class all-white with soft, creamwhite throat. Fine, slender stem and beautiful cut flower. Exceedingly popular at the A. G. S. show, Rochester, Aug., 1925. Displayed in a basket with "Golden Tinge," won first prize, A. G. S. bronze medal. In a funeral basket with "Blanche Bollinger" and "Elba," won first prize, A. G. S. Trophy. In another basket with "Taurus," first prize, A. G. S. bronze medal, and at the same show took first prize for the best white Primulinus Hybrid. In 1926 first prize was again awarded this variety for best white in Primulinum class. Illustrated on page 78. Each, 15c. Doz., \$1.50. 100, \$11.25

Yellow Prince (1929. 66 days.)-Tall showy plant with five and more very widely spreading pointed petals open at a time. Color of upper and central lower petals is a very pure soft lemon or deep sulphur. Two lower inside petals are a deeper canary yellow extending down the throat. A very refined and beautiful gaint yellow. Each, 75c. Doz., \$7.50.

Zona (R-1927. 67 days.)-(Grandiflora Primulinus)-Attractive plant. Deep salmon rose color. Lower petals rich deep canary-yellow, outer portion a lighter shade of the main color. Deep rose-pink blotches on center of lower petals. A fine flower in every way and sure to please. Blooms of this variety were used in making the prize winning bride's bouquet at the A. G. S. 1926 show, A. G. S. Trophy. An award of merit was also given this variety for the best seedling Primulinus Grandiflora type. Each, 25c. Doz., \$2.50. 100, $\$ 18.75$.

\section{FROM ENGLAND}

Your letter of the 18th ult. reached me on Monday last, and the bulbs arrived on Tuesday. They were unpacked at once and looked in splendid condition, and I have no doubt that they will give a good account of themselves.

I thank you for including some extra bulbs, all of which are new to me, and I shall be interested in watching them bloom.

Yours faithfully,

GEORGe ChuRcher

Beckworth, Lind field

Hayward Heath

Sussex, England

\section{Collection Offers \\ PRIMULINUS VARIETIES}

These Collections Are All Sent with Each Variety Properly Labeled

Collection No. 49-All varieties valued at 10c, 9 in all (value 90c) for ...80c

Collection No. 50-All varieties valued up to and including 15c, 19 in all (value $\$ 2.40$ ) for. $\$ 2.15$

Collection No. 51-All varieties valued up to and including $20 \mathrm{c}, 23$ in ali (value $\$ 3.20$ ) for.

Collection No. 52-All varieties valued up to and including $25 \mathrm{c}, 28$ in all (value \$4.45) for.

$\$ 4.00$

Collection No. 53-All varieties valued up to and including $35 \mathrm{c}, 38$ in all (value $\$ 7.95$ ) for.

Collection No. 54-All varieties valued up to and including 50c, 46 in all (value $\$ 11.95$ ) for.

Collection No. 55-All varieties valued up to and including $75 \mathrm{c}, 54$ in all (value $\$ 17.95$ ) for. $\$ 16.15$

Collection No. 56-Entire collection, one each of the 55 varieties listed (value \$18.95) for. $\$ 17.05$

Varieties Included in These Collections Are Listed on Pages 76 to 81

A. E. Kurderd, Goshen, Indiana 


\section{Laciniated Gladioli}

\section{Kunderd's Latest Creation}

Imagine Gladioli so perfect that you would think a fairy had cut them out with a small pait of scissors, painted and twisted the petals in most unusual and artistic shapes, then you will have a mental picture of the Laciniated Gladioli. This is a race which I originated and which is very different from all the others. A bouquet of Laciniated Gladioli is an object of tare beauty. They are especially desired for delicate floral work. If you desire flowers which are outstanding and tare, be sure to include varieties from this group.

Adair (1929. 62 days.)-Fine height slender plant. Flowers have beautiful recurved and twisted petals, nicely laciniated. Upper petals are creamy white and lower petals a dainty soft canary yellow. A very dainty and beautiful variety of this new type. A dainty beauty. The daintiness and gracefulness of the laciniated varieties make them very popular for basket work. Each, \$3.00. Doz., \$30.00.

Aquila (1929. 66 days.) - Very tall rather strong plant for a laciniated variety. Five or more blooms open at a time and not quite touching each other. Color a deep cream with delicate blush towards outer portion of all six petals. Lower petals a beautiful delicate canary yellow over entire throat. Petals beautifully curved and twisted giving the dainty blossoms a very artistic effect. Each, \$2.00. Doz., $\$ 20.00$.

Comet (1928. 74 days.)-A deep golden yellow laciniated variety with large, red throat blotches. A very rich, deep yellow of pleasing appearance. Each, 50c. Doz., \$5.00. 100, \$37.50.

Fimbriatus (1928. 70 days.)-Tall, fine plant, five or more blooms open at a time. Upper petals fine, deep cream or soft sulphur. Lower petals delicate apricot yellow with fine, brownish pink median lines. True Laciniated type but sometimes more or less laciniated. A very neat and pretty flower and well worthy of a place in this new class. Each, \$1.50. Doz., \$15.00.

Hyperion (1928. 60 days.)-Fine, tall plant deep orange scarlet or vermilion. Lower petals deeper orange. Very graceful, irregular petals. Entire flower, all the petals, bordered daintily with a clear, narrow line of yellow. Back of flowers finely stippled and beautifully penciled orange yellow. A very showy flower in this new race and larger than "Lacinatus." Each, $\$ 1.50$. Doz., \$15.00.
Impresario (1928. 87 days.)-This is Kunderd's largest and grandest Laciniated. Color, upper petals a beautiful, mellow, light, clear lemon yellow. Lower petals most beautiful canary yellow with very delicate central narrow line of golden yellow which is a soft pink in some of the flowers. A very wonderful flower of most wonderful orchid-like appearance and a fine seed producer. Well worth $\$ 100.00$ to the breeder. Scarce. An attraction for your garden. Each, \$7.50.

Interlude (1928. 69 days.)-A good, tall plant and a large flower of light yellow-deeper yellow on lower petals. Five or more perfectly placed flowers open at a time. Rapid multiplier, sometimes more laciniated in some flowers than in others. Each, $\$ 1.00$. Doz., \$10.00.

Lacinatus (1923. 69 days. Rating 90)The forerunner of another new Kunderd race of gladioli. Beautiful rosepink and under good culture will reach the size of $3 \frac{1}{2}$ inches to 4 inches in diameter. Spike is slender, graceful and of good height. Very artistic and especially adapted for fine floral work in dainty decorations. A dainty thing when forced on the greenhouse bench, and as it is a most artistic gladiolus it is certain to become a very popular variety when the stock is once in sufficient supply. A large size bulb will produce four and five spikes of blooms. Illustrated on opposite page. Each, 20c. Doz., \$2.00. 100, $\$ 15.00$.

Lavender Beauty (1927. 69 days.)Pinkish lavender, flaked deeper lavender. Lower petals a little lighter in throat with slight throat markings and narrow central lines. Nice, slender plant. A worth-while addition to the laciniated type. Each, 50c. Doz., \$5.00.

Little Doll (1931) - Tall fine plant with small widely expanded and well laciniated flowers. Color pale creamy white on upper petals. Lower petals 
soft creamy yellow neatly striped, and feathered brownish pink. A neat new laciniated variety. Each, \$1.00. Doz., $\$ 10.00$.

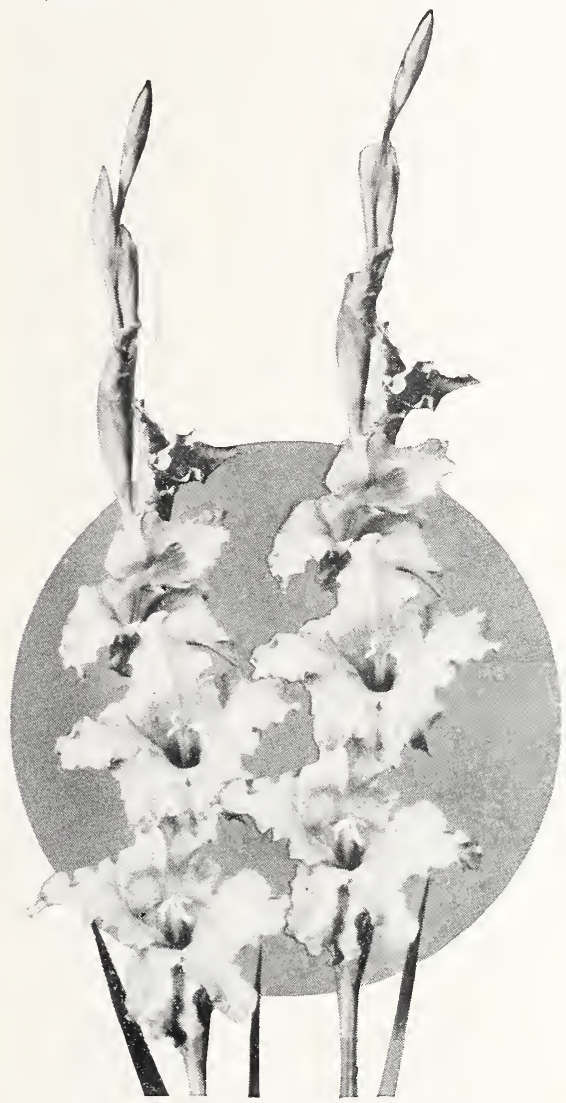

LACINATUS-Described on Opposite Page
Pierian (1928. 70 days.)-Tall, slender and graceful plant with six or more finely spaced flowers open at a time. Upper side petals very upright, bird's wing like, and central upper petals very hooded giving the flower quite an orchid-like appearance. Color of upper petals soft canary yellow, lower petals deeper canary yellow with only a very narrow thread line of pink brown down the center. Sometimes more laciniated than others. Each, $\$ \mathbf{1 . 0 0}$. Doz., \$10.00.

\section{GOLLEGTION OFFERS OF LACINIATED VARIETIES Listed on Pages 82 and 83}

Collection No. 57-All varieties valued up to and including $50 \mathrm{c}, 3$ bulbs in all (value $\$ 1.20$ ) for............\$1.05

Collection No. 58-All varieties valued up to and including $\$ 1.00,6$ bulbs in all (value $\$ 4.20$ ) for............. $\$ 3.80$

Collection No. 59-All varieties valued up to and including $\$ 1.50,8$ bulbs in all (value $\$ 7.20$ ) for............. $\$ 6.50$

Collection No. 60-All varieties valued up to and including $\$ 2.00 .9$ bulbs in all (value $\$ 9.20$ ) for.............\$8.30

Collection No. 61-All varieties valued up. to and including $\$ 3.00,10$ bulbs in all (value $\$ 12.20$ ) for............\$11.00

Collection No. 62-Entire collection, one each of the 11 laciniated varieties listed in this collection (value $\$ 19.70$ ) for. $\$ 17.75$ Each Variety in Collections Is Properly Labeled

\section{Nezw "Snapdragon" Type}

A distinctly new type varying from other types to as great a degree as the ruffled vary from plain petaled Gladioli. The shape of these flowers resembles the snapdragon so closely that it suggested the name I have given this attractive new type.

Snapdragon (1915. 68 days.) - Tall spike, fair sized flower. Reminds one of a snapdragon in its remarkable form. Large, rich, pure yellow throat with bright-red border. Exceptionally distinct and beautifully ruffled. Each, 25c. Doz., \$2.50. 100, \$18.75.
Golden Snapdragon (1929. 66 days.) (Intensely ruffled)-An extraordinarily beautiful Gladiolus of the snapdragon type. The upper petals are of a refined creamy-white shade. The lower petals are also of same shade for the lower or inner half of the petals, but the outer ends are of a very rich, soft canary-yellow. These yellow ends are gracefully curved. This type is sure to become popular as stocks become plentiful enough to meet the demand. Each, 75c. Doz., \$7.50. 


\section{Thousands of Choice Varieties in These Mixtures}

\begin{abstract}
THE standard of my Gladioli in mixture has also been improved in recent years to the same great degree as my newer named varieties have been improved over most of those of earlier years. I have realized for many years the importance of fine mixtures and have therefore given a great deal of attention to them, because only in this way can the thousands of beautiful varieties be furnished as it would be impossible to ever name or number them all.

To secure the greatest variety and beauty from Gladioli, it is absolutely necessary to grow them in mixture also. Any one who has ever had the pleasure of visiting a first-class collection grown in mixture will appreciate this statement.
\end{abstract}

Originators find their highest enjoyment in growing greatest numbers of kinds together, and the average grower for pleasure will derive an equal benefit by growing them in the same way. If I were permitted to grow only a limited number of kinds, each under name and number, or many varieties in a mixture, I would certainly decide in favor of the latter method, for in this way only is it possible to secure and enjoy the almost limitless variety and beauty to be found among the Gladioli.

To secure the best value and variety it is necessary to obtain a considerable number of bulbs, and at the very low prices at which I am offering these bulbs it places them within the reach of all.

In the purchase of bulbs from any of these mixtures it is understood that no one is allowed to name any of the varieties.

\section{Glory Mixture}

\section{It Glorifies the American Garden}

THIS extraordinary mixture comprises 1 over twenty-five hundred new varieties, and well balanced in colors to give you a wide selection even from a moderate purchase. There are many ruffled varieties to be obtained in buying this mixture as well as plain petaled kinds. Every color and shade known to the Gladiolus is included, and the many different forms to be found will also prove a great pleasure to the purchaser of this very fine mixture. During each summer many visitors call on me and when they see this fine mixture they are amazed at the great variety and value I am able to give my customers at such a moderate price. Many of the varieties, if sold under name, would cost several dollars each, but by growing in a mixture I am able to sell at a price that would be impossible when the kinds are grown separately.

\section{$\$ 9 \underline{50}$ per 100 $\$ 1 \underline{35}$ per Dozen 25 AT THE 100 RATE 6 "6 " Doz. "}

\section{Ideal Mixture}

\section{A Pageant of Magnificent Colors}

THIS extra fine mixture this year is 1 so much improved by the addition of many beautiful, new varieties that it is practically as fine as my "Glory Mixture" of last year. No one else can supply a mixture of such high quality. I always add many fine, new kinds to all of my mixtures each season so as to each year enable my customers to secure the better varieties and kinds not procurable elsewhere.

This might be described much as the "Glory Mixture" is described, the principal difference being, that the "Glory
Mixture" contains a greater proportion of ruffled varieties and more new kinds are added to the "Glory Mixture" each year than are added to the Ideal.

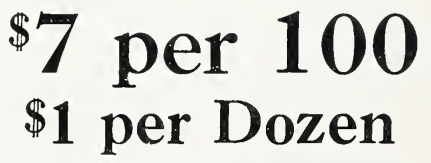

25 AT THE 100 RATE 6 66 6 Doz. 66

See Special Collection Offers, Pages 15, 21, 30, 35, 47, 74, 75, 81, 83 


\section{Wonder Mixture \\ "A Crown of 10,000 Jewels"}

I my many years in growing and developing new Gladioli I have constantly striven to produce the best in mixtures as well as the best in named varieties, as in a mixture it is possible to grow the greatest numbers with the least expense and care. Because of the many commonplace mixtures which have been placed on the market in years past, the public confidence has been somewhat "jarred" and they have become suspicious of the word "mixture." The thousands of people, however, who for years enjoyed the gladioli that they have received from me in my four older mixtures are in readiness to vouch for them. With a greater and still greater goal before me I strove for even better mixtures and

have attained my ideal in my new "Wonder Mixture." To realize that such a high quality mixture is obtainable at the reasonable price I am asking for it, considering the quality, is sure to be a joy to my customers.

\section{$\$$ \\ $12 \frac{50}{\text { per } 100}$ $\$ 1$ 75 per Dozen 25 AT THE 100 RATE 6 6 "6 Doz. "6}

\section{Grand Mixture \\ As Lifelike as Butterflies}

THE most beautiful of the delicate 1 pastel tints are to be found in this collection of Primulinus Varieties, and no other race of Gladiolus contains such harmonious blendings as do the Primulinus Hybrids. This mixture contains upwards of two thousand varieties and a very choice combination of colors and shades. I consider the Primulinus $\mathrm{Hy}$ brids the most beautiful type of gladioli.

\section{$\$ 6 \underline{00}$ per 100 $\$ .90$ per Dozen}

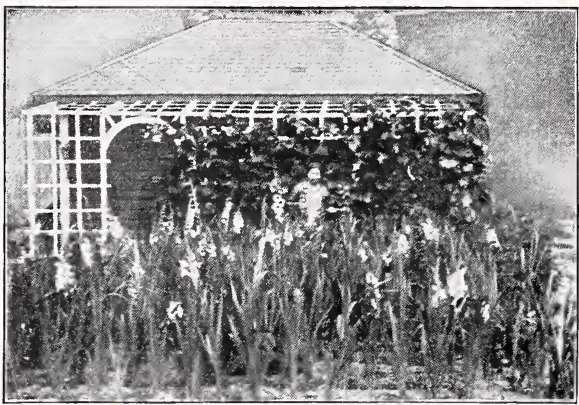

In the garden of Mrs. E. C. Jameson, Ohio A model small garden

\section{AT THE 100 RATE - - 6 AT THE DOZEN RATE}

\section{Orchid Mixture}

\section{As Beautiful as Orchids}

I OFFER you in the "Orchid Mixture" this year thousands of Primulinus Hybrids carefully selected from my seedlings of the past few years to give you the most extraordinary assortment in this fine collection this year. The earlier Primulinus Hybrids consisted principally of yellow and orange colors, and while this is still true to a great extent there are more shades in the Primulinus than ever before. In this mixture you can expect the most recent improvements in this really wonderful type of Gladiolus and very little duplication, because it is very new. This type is superior to other types of Gladioli in pastel shades and daintier flowers for decorative purposes.
They rival the Orchids. In fact it is this type that is often referred to as the Orchid type of Gladiolus. I offer this splendid new mixture with every confidence that it will please my most critical patrons, and prove a revelation of the advance being made in this popular new strain.

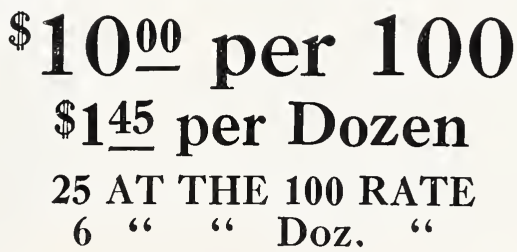

A. E. Kunderd, Goshen, Indiana 
$\mathrm{F}$ LOWER lovers everywhere are filling their gardens with beautiful Gladioli and are adding the newer and finer things each year. Many business men and women are bringing together large collections and are making the Gadiolus their principal garden attraction.

Gladioli are easy to grow and are the most adaptable of all garden flowers. Nothing else of their class costs so little or blooms so readily, in any soil and every climate. Their blooming season is long and their color varieties are literally unlimited.

The ease of culture, and their comparative freedom from diseases and insect enemies, make the Gladiolus, without doubt, the most satisfactory flower to grow, even by the most inexperienced, and no other flower gives so great and so certain returns for the same amount of labor and effort.

The bulbs you buy can be used for years to come and the comparatively few hours devoted to their growing will be considered a "labor of love" by all who cultivate them, because they will be repaid so many times over for the little effort required. Grow at least a small collection selected from the extensive list I offer you here and you will be most enthusiastic about your experience. Your success will be greatest if you follow the simple suggestions about planting, care and storage explained here:

Selecting the Stock: First of all it is necessary to begin with good bulbs (corms) of good varieties. This does not necessarily mean the most expensive, as many of the moderate priced ones are among the best, their price being lower simply because they are more plentiful.

Gladioli are universally successful in every section of this country while many other flowers can only be satisfactorily grown in certain localities. In the Northern States blooms can be produced from late June and early July until hard freezes begin; often very late in the fall. In the Southern States, in California and elsewhere, the season of course begins earlier and extends almost into the winter of the North.

Soil Suggestions: Any good garden soil is suitable. If of a clayish or heavy composition it can be mellowed by addition of sand, sandy loam, muck, etc. In preparing the soil it is necessary to follow only such methods as would give you a fine crop of garden vegetables.
Where to Plant: It should be remembered that Gladioli enjoy sunshine and should not be planted in very shady places. Plant in rows or beds, in borders or among shrubbery, roses, etc. Plant in separate groups or among other flowers and plants. Plant marigolds, zinnias, asters and other flowers among your Gladioli as well as Gladioli among other flowers and plants, and you will discover many possibilities for delightful effects. I would appreciate reports of your experiments as such information may prove valuable to others growing Gladioli.

Location and Preparation of the Soii: It is of advantage, when possible, to use new location or soil each season so that bulbs are not planted more often than every second or third year in the same soil. Spade in a good covering of manure in the fall preceding the planting. The richer the soil and the better the care and culture the better the results will be. In the spring, when the soil is in proper condition, spade deep and pulverize thoroughly.

Planting: Planting should begin as soon as early garden-making will permit and be followed by successive planting's, of say ten-day intervals, until early June in our Northern States and later in the South or they may all be planted at one time. For particularly late blooms they may even be planted as late as July first in the North. The later plantings bloom in a shorter period after planting because of the warmer weather and better ground conditions. This applies to all climates and countries. Also the larger bulbs of equal quality come into bloom a little sooner than the smaller ones. The smaller bulbs may not produce as large spikes but the individual blooms will generally be as large and, if of high quality to begin with, will be more valuable over a period of years and give a much larger increase in new bulbs and bulblets.

Depth of Plant: Bulbs may be planted four inches deep or over in mellow soil, and four to eight inches apart in the row. Rows should be eighteen inches to two feet apart. They will, however, stand closer planting if the space is limited. While deeper planting will help to keep plants from falling over at blooming time they should be staked to protect them against heavy winds.

Fertilizing and Feeding the Soil: When planting, use only well rotted manure or

(Continved on Page 89) 


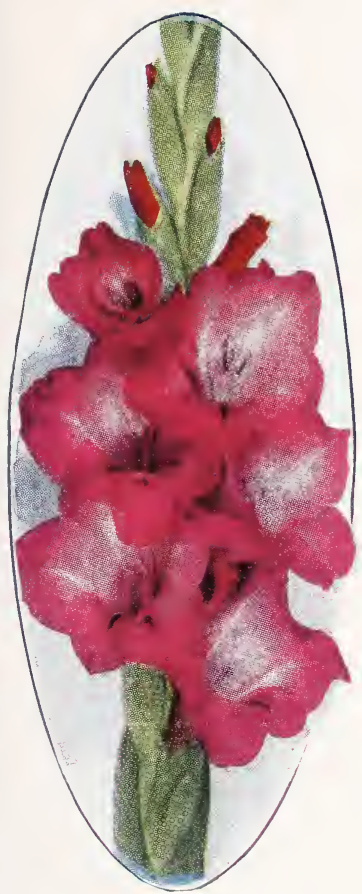

Dr. Nelson Shook

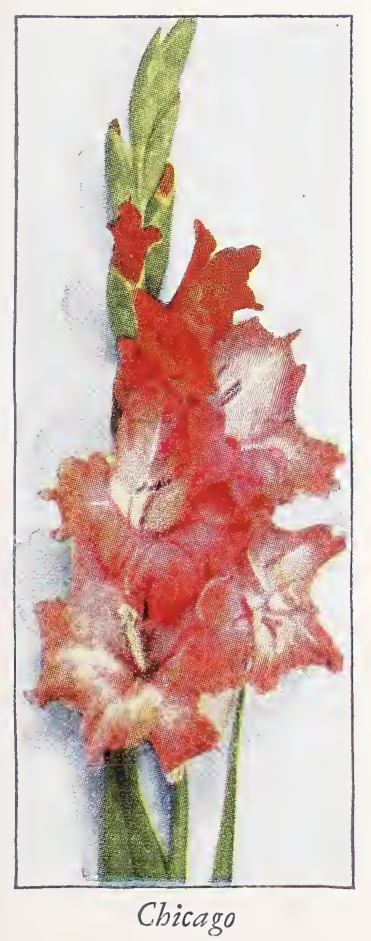

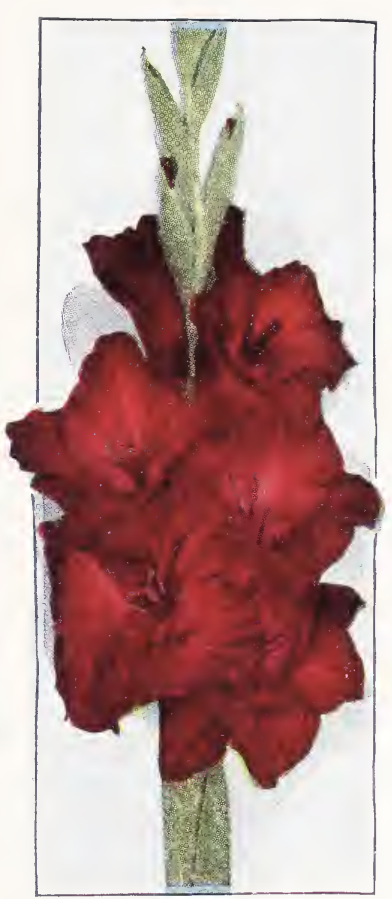

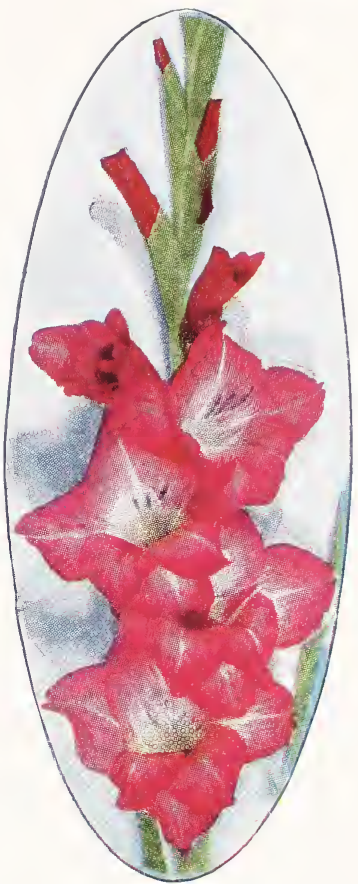

Tyrian Beauty

Thomas A. Edison
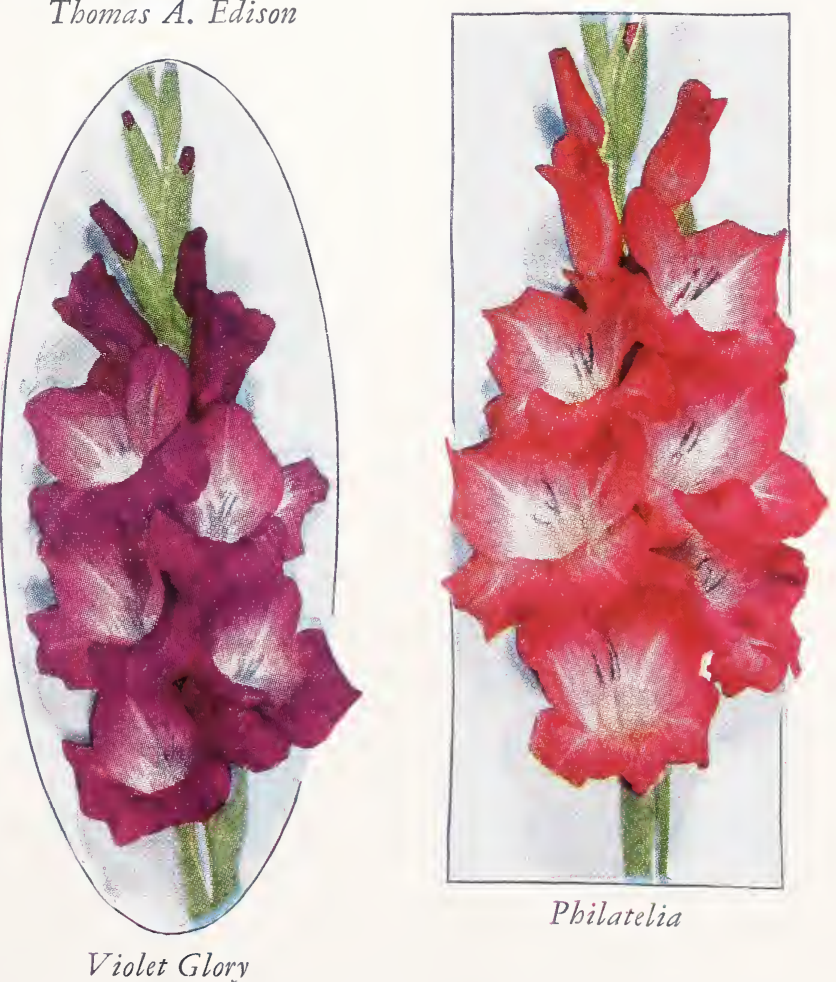

For Descriptions of Color Illustrations Refer to Index 


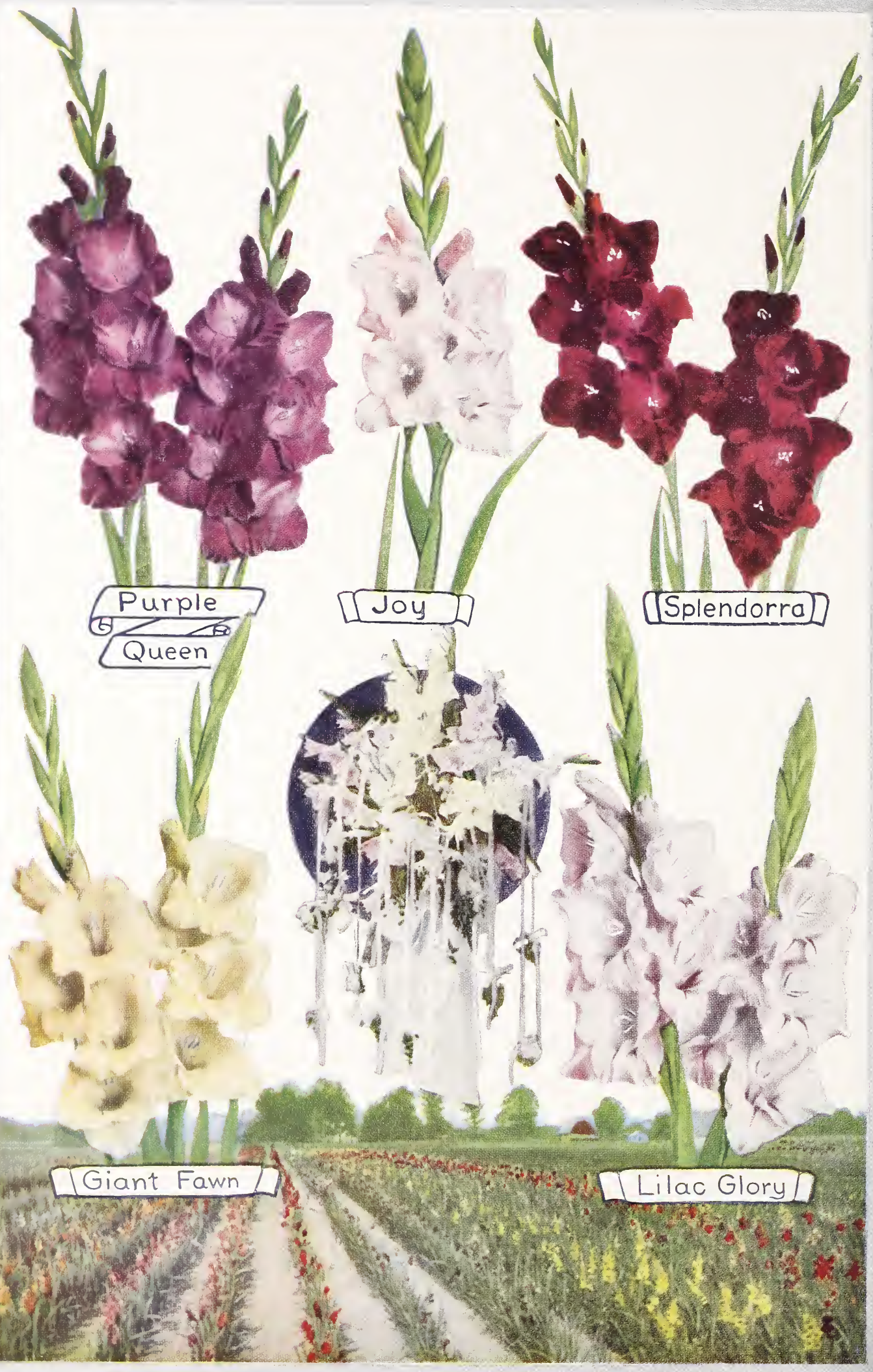

For Descriptions of Color Illustrations Refer to Index 
(Continued from Page 86)

high-grade potato fertilizers. Liquid fertilizer or prepared sheep manure may be applied to the soil near the rows, once every ten to twenty days, care being exercised not to make applications too strong. Frequent, thorough waterings of the soil in the evening is a wonderful stimulant and gives the blooms much greater sun resistance and lasting qualities. Prepared, ground bonemeal, or a high-grade potato fertilizer can be sprinkled over the soil near the plants, between rows, and raked in to good purpose. Nitrate of Soda (a tablespoonful to two gallons of water for each dozen plants), applied to the soil near the rows once each week or ten days after buds begin to show color is very beneficial. Or you can sprinkle the pulverized nitrate of soda over soil, rake in, and water.

Cultivations: Keep the soil well and frequently worked, especially early the next forenoon after watering the previous evening. Water thoroughly at intervals of several days. Excepting in exceedingly dry periods do not water daily. Over-watering is an injury. Keep soil crust from forming in the rows among the plants. After blooms begin to show, cultivate the soil to a lesser depth. Do not work the soil when wet.

A Good Thing to Remember: The three greatest essentials to successful growing of Gladioli, as of most everything else, are-good soil, good and frequent cultivation and plenty of water. When plants begin to ripen, watering should be lessened.

Staking: Slender stakes of light wood or bamboo painted light green make good supports for the spikes at blooming time. When horizontal lines are used they should be fastened to end posts firmly set, and wires tightly stretched. A few more stakes should also be placed at intervals along the lines. Use strips of cloth instead of cords to tie blooming spikes to their supports.

Marking: Painted white pine labels, copper wired, are very suitable for marking plants. As an accommodation to my customers I will supply such painted labels, with bulb orders only, at the rate of 2 for 1c, prepaid.

Blooming: The Gladiolus surpasses all other flowers for cutting purposes and good keeping qualities. Personally I prefer to bloom Gladioli in the house, cutting the spikes when the first two or three flowers open. Cut with a sharp knife to avoid bruising the stems. Cut spikes so as not to remove any more of the foliage than is necessary, leaving about four good strong leaves to develop new bulbs for next year. Each morning remove wilted blossoms, cut off a little of the stems, with a long slanting stroke (not square across), rinse and give fresh water. Keep inside of vases, etc., clean. The flowers will last longer if these suggestions are followed. Placing the cut Gladioli in a cool cellar overnight refreshes and improves them.

After Blooming Season is Over: Shallow cultivation should be continued in order to develop good strong bulbs for next season. Less watering is needed from this time on and especially as the harvesting time approaches. As soon as the foliage begins to turn a yellowishgreen, usually four to six weeks after blooming, the bulbs are then ready for-

Digging and Storing: If the greatest increase of cormlets is desired, bulbs may be left in the ground longer than above mentioned though they should be dug before hard freezing. When digging, cut off the tops close to the bulbs. Dry well in the air and sunshine. Cure thoroughly indoors for a few weeks, then store in a cool, dry cellar. A covering of sand while in storage (after bulbs are well cured) is a protection against frost or dampness. Keep as near forty degrees as possible. Dampness in storage tends to develop disease.

It is best not to pile bulbs to a depth of more than four inches while in storage. Florist's flats are most suitable for this purpose. Such a crate may be made with sides and ends of four-inch boards, using plastering lath, closely laid, for bottoms. Make crates two feet square or $24 \times 30$ in., as may be best suited to your purpose.

Cleaning Bulbs: Bulbs should be cleaned about six weeks after digging, that is, to remove from the bulbs all roots and bulblets. To leave them on until planting time is an injury to the bulbs.

You will find these simple cultural directions amply sufficient to assure abundant returns. Try at least a small collection of the newer Gladioli in your garden this summer. Add to them from year to year and you will find no occupation more pleasant than the time you spend among these beautiful flowers.

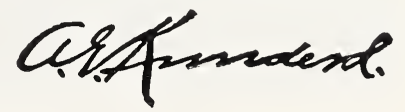


"SPRING Has Come"-the words just

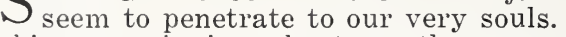
Robins are singing about us, the warm sun rays are here and it's time to make our gardens. How we long for Spring and the privilege of turning up the soil to plant the seeds that will transform the barren spots left by the Winter blasts into pageants of glorious colors! Gene Stratten Porter once said, "There are few joys in the world equal to the joy of a garden, and a garden sets off a home as an appropriate frame does a picture."

Those who have planted seeds, those who have made gardens, can appreciate the real joy and satisfaction to be had; those who have not had this opportunity have still in store for them a real treat. The task is simple and easy, the work healthful and invigorating, and the reward far beyond your fondest expectations. The cost of making a fine garden is but very small.

Every year more and more people are making gardens, others are continually adding to their present gardens. In order to better serve my customers I have made many additions to my seed listings this year which I am sure will meet with instant approval.

Many of the disappointments with flower seeds are due to lack of proper conditions, and while it would be impossible, in the small space available in this catalog, to give definite instructions I believe if you will follow the general

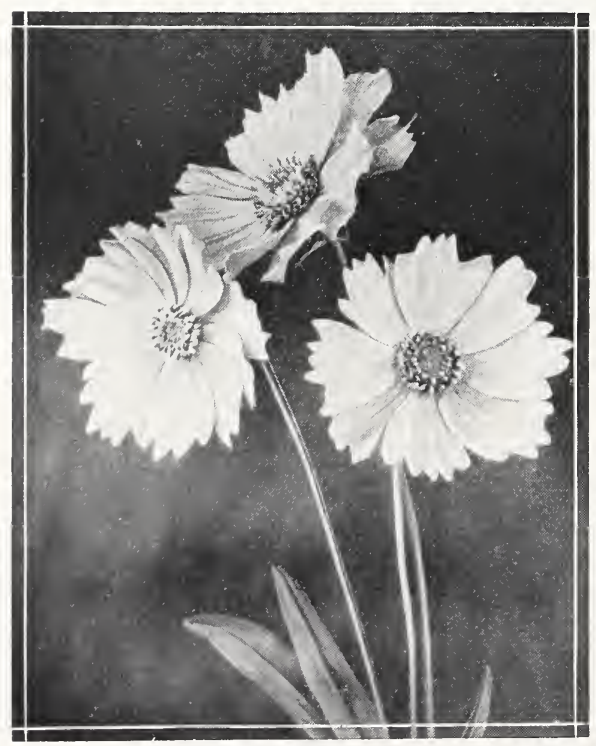

COREOPSIS directions given here that you will have good results.

Most flowering plants will live in almost any soil, but to give them a fair chance to develop, some care should be taken to make the ground suited for their needs. The soil best adapted for flowering plants generally is a light, friable loam, containing a sufficient amount of sand to render it porous. Many flowers are better if produced on plants of vigorous growth, hence a portion of the garden should be prepared by deep digging, thorough pulverization and liberal enriching with large quantities of well-rotted manure. Since some other varieties produce the largest and finest colored flowers when grown on rather light, poor soil, a portion of the garden should not be enriched.

Cultural directions are given on the packets, and I urge purchasers to study them carefully. While some seeds need special treatment, this general rule will apply to all. Make the surface of the soil as fine, smooth and level as possible, and do not plant when the ground is wet.

The vitality of all the seeds is tested before sending them out, and only those of strong germination are sold. Most failures of seed are due to causes beyond my control, such as unfavorable weather and soil conditions; sowing too deep or too shallow; insects of different descriptions destroying the plants as soon as or before they appear; all of which render it impossible for me to guarantee success. While I exercise the greatest care to have all seeds pure and reliable, in common with other seedsmen, I give no warranty, expressed or implied, and will not be responsible in any way for the crop. If the purchaser does not accept the seeds on these terms and conditions, they must be returned at once.

\section{NOVELTY LIST}

\section{*A-Annual *P-Perennial *B-Biennial}

Ageratum (Blue Cap)*A. A new very dwarf and compact variety, blooming freely with larger flowers than any of the older dwarf sorts, splendid for edging.................Pkt. 25c Aquilegia Coerulea Cuprea (Copand distinct color of this beautiful flower. The petals are broad and of a decided copper-red with long spurs of a darker hue, and the corolla is a straw color changing to white which produces a charming effect.

Pkt. 35c

Aquilegia Long S purred Hybrid (Crimson Star)* $\mathbf{P}$. This is a distinct 
color in the Long Spurred Aquilegia, a brilliant dark crimson, splendid for mass effect, one of the best of the season's novelties............................................................... 25c

Aquilegia (Red Riding Hood) *P. A charming variety of double Aquilegia. Umbrella like, color old rose. Calyx is spread out above the pure white double corolla of these dainty blooms; a very uncommon and effective color combination.

Pkt. 50c

Aster (Sunshine.)*A. This is an improved Anemone Flowered Aster of great beauty; all the flowers have a cushion-like center of tiny quills of a contrasting color which adds to their decorative value-there are many shades of pink and blue, also white in the seed we offer which may be depended upon to supply the most attractive asters for cutting; their delicate beauty is hard to describe, the flowers are borne on long stiff stems and last a long time in water.

Pkt. 25c

Calendula (Campfire.)*A. Calendulas are easy to grow, very decorative in the garden and one of the most lasting flowers when cut for decorative purposes. Campfire is a distinct and much improved variety. The very large double flowers are a brilliant orange with a scarlet sheen which enhances the beauty and general character of the flower and are borne on extra-long stems

Pkt. 25c

Calendula (Radio)*A. Medium size orange flower with quilled or comet petals, curled and twisted, borne on medium length stems. Recent introduction from Europe.

Pkt. 25c

Coreopsis New Double Flowering (Lanceolata Grandiflora Fl. Pl.)*P. Coreopsis Lanceolata has for a long time been a gem in the perennial border. This new double and semi-double form is just as easy to grow and the extra petalage adds a further charm to the flower. Will bloom first season if seed is sown early.

Pkt. 25c Cosmos Early Express Bright Pink. mos, flowering within fifty days from planting. Valuable also on account of its dwarf habit of growth, $2 \frac{1}{2}$ to 3 feet. Blooms freely.

Pkt. 25c

Cosmos-New Extra Early Double Flowered.*A. This valuable flower grows to a height of about three feet, forming a perfect bush massed with bloom, bearing beautiful double flowers of good size on long stems. This strain comes about seventy-five per cent double from seed. They bloom in seventy days from planting, so that seed sown the latter part of April will easily be in bloom by the Fourth of July and continue till cut down by frost.

Pkt. 25c
Cynoglossum (Chinese Forget*A. A lovely plant 18 to 24 inches tall with flowers of a true Forget-Me-Not blue. It is a hardy annual of recent introduction from China; will thrive in warm weather better than the ordinary Forget-Me-Not. It is ideal for bedding as well as for cut flowers.

Pkt. 15c

Cynoglossum (Pink)*A. A new color, same habit of growth as Blue and White, makes a very dainty and pretty cut flower .................................................................Pkt. 15c

Delphinium (Blue Bird Strain.) beautiful Perennial Larkspur is procured from one of the finest and largest collections of Delphiniums in this country. A collection-the result of testing the most famous strains procured from all over the world and selecting the finest. The range of colors vary from the palest shades of blue to the deepest indigo and royal purple with many intermediary pastel tones of mauve, pink, and lavender blendings and combinations difficult to describe. The huge flowers are single, semi-double and double and bear on graceful long stems; the semi-double flowers are the most admired...........Pkt. 50c

Delphinium (The Hollyhock), Watkin Samuel's English Wrexham Strain.*P.Pudor, a Delphinium specialist writes in regard to this fine strain: "This is the last word in English Delphiniums. They are now blooming in my garden-and so

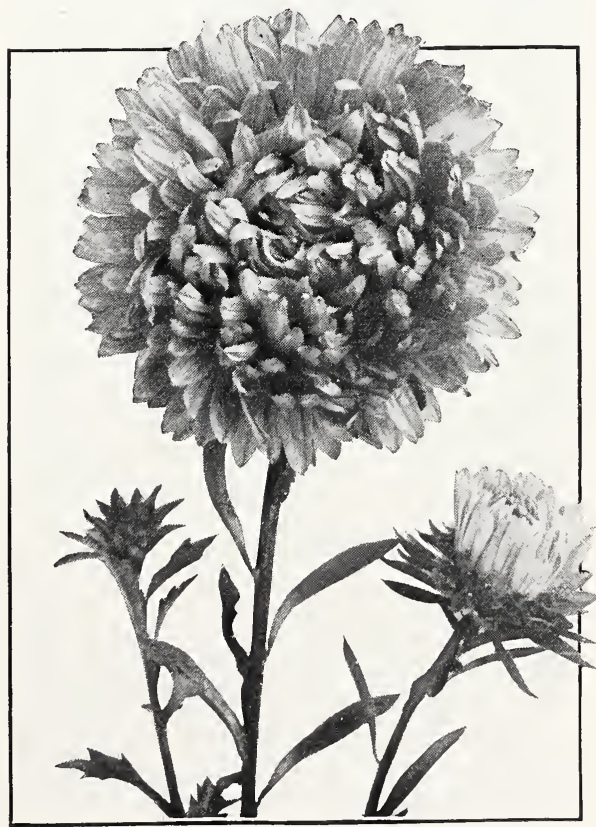

ASTER

A. E. Kunderd, Goshen, Indiana 
marvelous and huge are they, that they take your breath away."

The Wrexham flowers are enormousthe "bees" immense. Watkin Samuel's stalks are superb; he has striven for church-steeple shaped, tall flower stalks, and he has succeeded................................Pkt.50c

Delphinium W r e $\mathbf{x}$ a m Coquette. ${ }^{*}$ P. Violet shaded to deep blue. Height, 6 ft.

Pkt. 50c

Delphinium Wrexham Queen Mauve.*P. $\mathrm{C}$ h a $\mathrm{rm}$ ing silvery-mauve. Height, 6 ft.

Pkt. 50c

Dianthus (S w e e t Wivelsfield)*B. $A$ new hardy annual, good for borders, as a cut flower, and especially adapted for rock gardens. Choicest home grown, hand picked seed. Mixed colors. Pkt. 35c Fremurus (Foxtail Lilies.) Grows iremurus 4 to 8 feet tall; very hardy. Very scarce in this country. Colors, yellow, pink and white. Only mixed colors can be offered this year.

Pkt. 35c

Gaillardia (Burgundy)*P. In this novelty, the dainty yellow edging has completely disappeared; thus it is the ideal of the all red perennial Gaillardias satisfactorily realized. The shining wine-red marguerites are produced liberally on long stems by the bushy plants $2 \frac{1}{2} \mathrm{ft}$. high. They flower

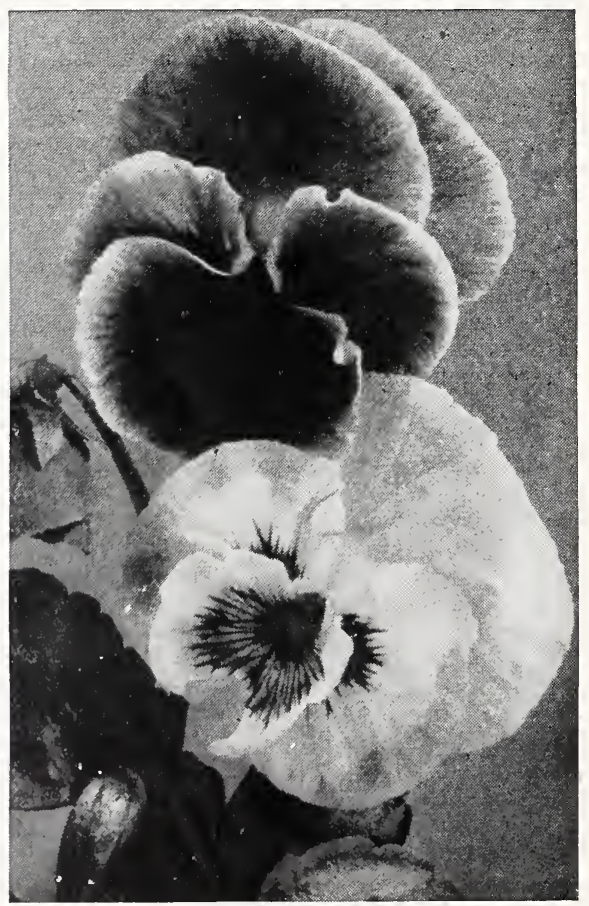

PANSIES from June until autumn and if sown in March blooms will appear the same year. 60 to 70 per cent pure red flowers can be counted on. Most effective both in perennial borders and when cut. Pkt. 35c

Gaillardia (The Dazzler.)*P. By far the largest and most attractive Gaillardia to be had. The flowers are very large of a dark, rich red with a bright orange tip on the end of each petal making it a very attractive flower for house decorations; has long stiff stems and great lasting qualities when cut. A flower of real merit...................................... 25c

Kunderd's Special.*P. New strain of Giant Flowered Gaillardias. Imported from Germany. Choice new colors. Extra fine. Perennial

Pkt. 25c

\section{Helianthus (Sunflower) Excelsior} Hybrids. A. This is an exceptionally fine mixture of small flowering Sunflowers with the red shades predominating and many of the flowers have a large red disk on a yellow ground which makes them a very attractive decorative flower. The average growth is 3 to 4 feet and branching; flowers may be cut with long graceful stems and will last a few days in water-are very suitable for planting among shrubs or in the rear of the flower border.

Pkt. 15c

Helichrysum (Straw Flower.)*A. very Pink. A pleasing new shade of the popular flower. The blooms are two inches in diameter and make a striking appearance either in the garden or when cut.

Pkt. 15c

Hibiscus (Mallow Marvels.)*P. Herbaceous Perennial, $r$ ed flowering strain, $5 \mathrm{ft}$. Blooms August to October. Showy ornamental plants for mixed beds or shrubbery borders or specimens. Blooms first year from seed if sown early. Sow seed $1 / 2$-inch deep, in May, and transplant to $2-3 \mathrm{ft}$. apart the second spring. The seed I am offering is of exceptional quality. It is a strain which I have been developing from the original "Meehan's" introductions. I have been selecting these and breeding them up through a number of generations and I think they are much better than any I have ever seen. The many visitors who come to my place and see these Hibiscus marvel at their great beauty. The flowers are very large and of a rich dark red color.

Pkt. 50c

Larkspur (Empress Rose.)*A. An introduction of unusual merit, the large double flowers are a rich rose color and are borne profusely on long straight stems that are excellent for cutting and charming in the open bud. 
Larkspur (Giant Imperial Blue Spire) *A. Intense deep oxford blue, same branching habit of growth as the popular Exquisite Pink.

Pkt. 25c

Larkspur (Giant Imperial Exquisite Pink)*A. A soft pink shaded salmon. One of the newer and very popular branching type Larkspur......................... 25c

Larkspur (Giant Imperial Lilac Spire)

* A. New this year, beautiful blue color of the same substance and size as the Giant Imperial Blue

Pkt. 25c

Larkspur (Giant Imperial White Spire) *A. A new pure white double Larkspur, with long showy spike, splendid for cut flowers

Pkt. 25c

Larkspur (La France.)*A. Not only a new color in Annual Larkspurs but of much better habit than the older varieties. Color is a very pleasing salmonpink and the large well formed double flowers are well placed on long stems making it one of the most desirable cut flowers

Pkt. 25c

Larkspur (Los Angeles)*A. R i c h salmon ground overlaid with a brilliant and pleasing rose. Type of growth similar to LaFrance but foliage is much darker green, making the large double flowers stand out more prominently. Both Los Angeles and LaFrance are particularly good under artificial light.

Pkt. 50c Lupinus (Lupine.)*P. English $\mathrm{Hy}$ famous strain. Tall, stately blooms, very fragrant. Mixed colors. Valuable for borders, beds or cuttings; prefers a little shade

Pkt. 25c

\section{Marigold (Tall African All Dou-}

ble)*A. New mammoth flowering Marigold, an improved Orange Prince, blooming practically 100 per cent double.

Pkt. 25c

Nicotiana (Crimson Bedder)*A. The Nicotinia Affinis, though valued as a fine decorative plant for groups and the rear ranks of borders, has hitherto not been found suitable for general bedding purposes. This novelty is a distinct break in this direction, being of dwarf and pyramidal habit, not exceeding about 15 inches in height. The flowers are of a rich deep crimson color and very freely produced, making a most striking effect when seen in the mass; "Crimson Bedder" comes fairly true from seed............................Pkt. 35c

Pansy (Swiss Giant Mixture.)*A. entirely different to any other Pansy The beauty, brilliancy and richness of the entirely new color tones is most striking. The perfectly round flowers are held on strong stems well above the unusually vigorous plants. Pkt. 35c
Petunia (Balcony $\mathrm{star}$ of California.) "A. Unsurpassed for window and porch boxes, blossoms freely, flowers very showy deep violet with crimson tinge and starred with five pure white blotches, long trailing branches.......................................................... 5kt. 50

Petunia (Marshall's Violet Queen.)*A. Exquisite single Petunia. Grows from 12 to 18 inches in height. Color, dark violet without a trace of magenta. Surpasses any of its type for border and bedding. Plants are robust and continuous bloomers with flowers averaging from two and one-half to three inches across from early summer until late fall............Pkt. 50c

Petunia (New Dwarf Fringed Rosy Morn.)*A. Bright rose. This beautiful new Petunia has all the lovely daintiness of the single Rosy Morn with the added attraction of the delicately fringed petals ............................................................. 35t. 35c

Petunia (Ruffled Giant.)*A. Flowers of extraordinary size and substance, and distinguished from the large flowering fringed section by deep fluting, giving the appearance as if artificially ruffled.

Pkt. 25c

Poppy (Iceland El Monte.)*A. A enormous size. A hybrid from Australia which comes true from seed in six months. Fine for decorations on account of its brilliant color......... Pkt. 50c

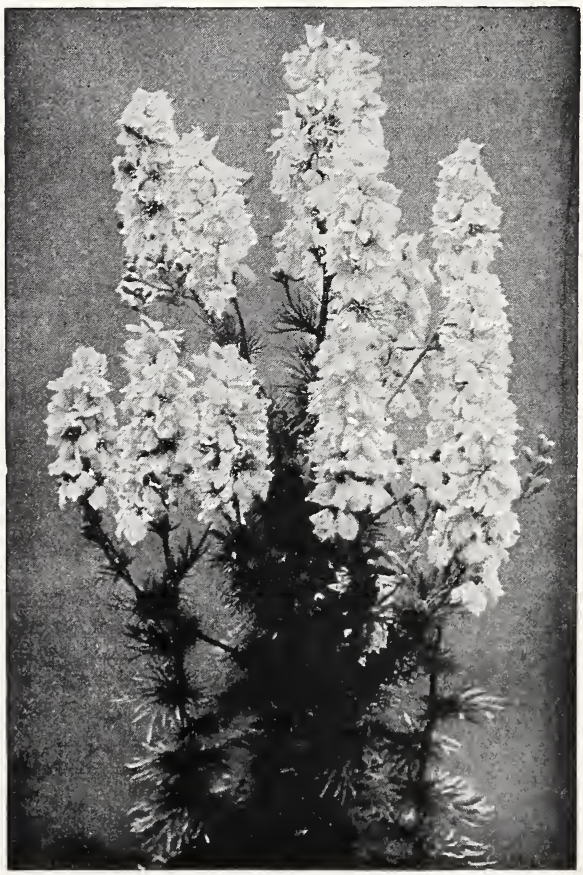

ANNUAL LARKSPUR-"LA FRANCE"

A. E. Kunderd, Goshen, Indiana 
Salvia (Flowering Sage.)*A. A Salvia hedge or bed of Salvia is a blaze of color during late summer and fall. They are used to good effect for bordering Canna beds, also for hedges along walks or lot dividing lines. Seed should be started either indoors or in a hotbed; sow about 1/4 in. deep; do not sow in open ground until soil has become well warmed. Transplant from 12 to 18 inches apart; all are treated as annuals.

Salvia "Wonder." A new kind, produces flowers so abundantly that the foliage is almost hidden, giving the beds the appearance of a brilliant red carpet.

Pkt. 25c

Scabiosa

(Giant Loveliness.)"A. A new color in annual Scabiosa, soft delicate Salmon Rose. Unsurpassed as a cut flower on account of its attractive color, delightful fragrance and long stems.................Pkt. 25c Verbena (Fireball.)"A. A new erbena dwarf Verbena about six inches high, literally covered with brilliant scarlet blooms. Especially valuable for borders

Pkt. 35c Viola Cornuta or Tufted Pansies p ilso known as P a n s y Violets, Johnny-Jump-Ups.)*P. While the flowers of the Tufted Pansies are not so large as the regular type, yet they bloom so freely that they are superior to pansies where effect is wanted. Seed sown in April produces flowering plants by June, and from then on until severe frost they are a sheet of bloom, if the seed pods are removed regularly. Violas are the best edging plants for the hardy border and are one of the most pleasing plants for the Children's Garden, the more flowers picked the better they bloom; do well in sun or shade.

Jersey Gem. New, deep violet blue. Pkt. 50c

Zinnia (California Giant.)*A. Miss Wilmott. A new color in the Mammoth flowering zinnias - a most delicate soft salmon pink. When in full bloom they make enormous show flowers - should be included in every collection of zinnias

Pkt. 25c

Zinnia (Crown of Gold.)"A. A magnificent new strain of the Dahlia Flowered types in beautiful two-tone color harmony of rose, yellow, carmine and burnished red, each petal overlaid with deep golden yellow at the base. A most striking novelty................ Pkt. 50e

Zinnia (D a h li a Flowered Golden Dawn.)*A. Enormous size, perfect type, golden yellow flowers................. Pkt. 25c

Zinnia (Dahlia Flowered Luminosa.) *A. Bright deep rose. The deepest and brightest of all the dahlia flowered rose shades...

Pkt. 25c
Zinnia (Picotte Delight.)*A. A new Pumila type, very free flowering and of compact growth. P etals of flowers ruffled and curled giving a light and dainty effect with the objectional stiffness removed. Very striking for borders or bedding. Colors range through salmon shades, cream, golden yellow and lavender

Pkt. 25c

\section{GENERAL LIST}

*A-Annual *P-Perennial *B-Biennial Ageratum (Little Blue Star.)*A. easy culture. May be started in hotbeds in March or seeded outside when the ground is warm. Plants grow about five inches in height. Bright blue..........Pkt. 15c. Alyssum (Little Gem.)*A. I know An no other flower which is so particularly well adapted for borders, ribbons, etc., as "Little Gem" Alyssum. The plants commence to bloom when quite small and will flower all summer long until late in the fall. Very compact

Pkt. 10c Antirrhinum (Snapdragon.)*A. Aing gorgeous coldragons. Antirrhinums or Snapdragons are now receiving the attention they deserve. They are undoubtedly one of the

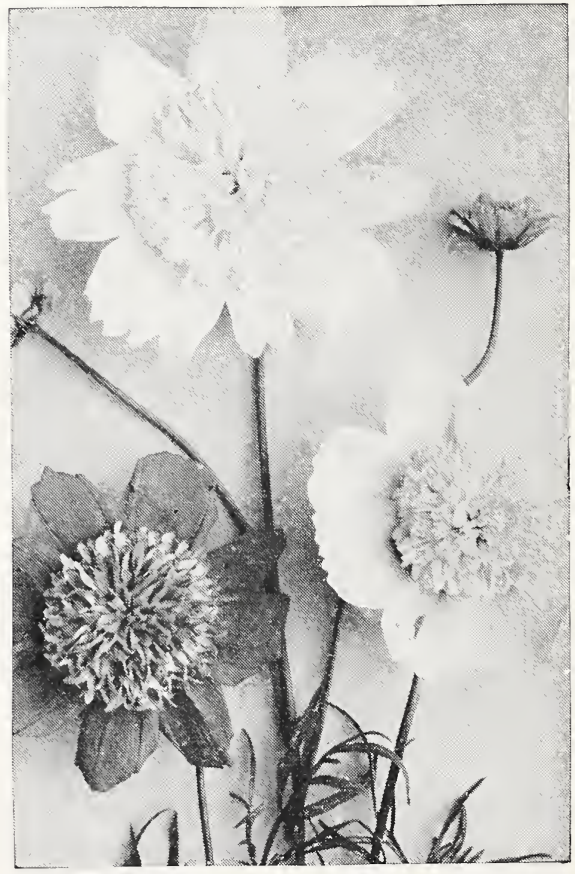

COSMOS-DOUBLE 
best cut flowers which can readily be grown from seed, while for beds or borders they are a constant source of pleasure, being in flower all the time. In the tall, giant flowering sorts, I am able to furnish the following:

Apple Blossom-Pink and primrose color Pkt. 15e

Defiance-Bright scarlet in color...Pkt. 15c Golden Queen - A very beautiful deep yellow Pkt.15c

Purple King Pkt. 15c

Rose Queen-Rose color Pkt. 15c

Ruby-Dark red

Snowflake-White ........................................ 15c

Venus - Pink on white ground, white throat superb …………...........................Pkt. 15c Giant Flowered Mixture. Pkt. $15 \mathrm{c}$ Aquilegia $\begin{gathered}\text { (Columbine.)*P. Hardy } \\ \text { Perennial. An old favor- }\end{gathered}$ ite. The plants form large clumps. Desirable as a border for shrubbery. Flowers profusely in different shades of blue, rose, yellow, purple and white. I offer an improved strain of Long Spurred Hybrids in a Mixture..................... Pkt. 15c Aquilegia (Columbines Double.)*P. In extra fine mixed colors. Hardy perennial. An old favorite. The plants form large clumps. Desirabie as a border for shrubbery. Flowers profusely in different shades of blue, rose, yellow, purple and white

\section{Asters *A. These flowers will thrive in any good soil, prepared in} the same way as you would for a crop of vegetables, but it is well to remember that any extra care taken in the preparation of the soil is repaid by finer plants, larger blooms, with longer stems and more profuse flowering.

California Giant. A combination of the large ostrich feathered type of flower with the long, branching stems of the beauty type.

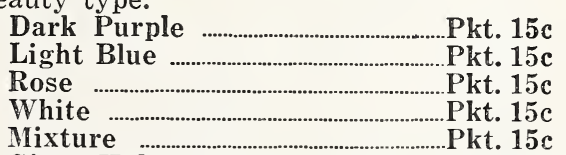

Giant Hohenzollern. A late branching Aster of the comet type. Immense flowers with beautifully broad, wavy petals. Fine for cut flowers. Mixture of all colors.

Pkt. 15c

Heart of France. A beautiful deep-red aster, splendid for cutting................Pkt. 15c

Kunderd's Premier Mixture. This Mixture is made up especially for those who wish to grow an assortment of Asters. It includes the cream of the best varieties: Early, Midseason and Late Flowering, as well as the novelties offered this year and the "Special Mixture." One may look with confidence for the Giant Hohenzollern, the strange Quilled Yellow, the wonderful new red, Heart of
France, Pink Enchantress, and indeed any of the lovely flowers in this fine list of Asters. A practical and interesting thing to do with this "Mixture" would be to plant it in a long row at one side of the garden and cultivate it with the vegetables, using the beautiful, striking and distinct flowers for cutting......Pkt. 50c Balsam (Lady Slipper or Touch-MeNot.) *A. A tender annual, with brittle stems and foliage. Grows about 12 inches high. Plants are profusely covered with large double waxlike flowers of brilliant colors, some selfcolored, others blotched, spotted, and striped in a wonderful manner. Desirable for garden or pot culture. Mixed varieties

Pkt. 10c

\section{Calendula (Pot Marigold.)"A. This} is the "Marigold" of Shakespeare's time; one of the best and showiest free-flowering, hardy annuals. Grows in any good soil and produces a fine effect in beds of mixed borders, particularly bright in late fall.

Lemon Queen, a rich lemon-yellow...10c Orange King, glowing orange................10c Mixture ...................................................... Pkt. 10c Calliopsis *A. Showy, free-flowerture, doing well in any sunny position, blooming all summer, and excellent for cutting and massing. It is best to sow them where they are to bloom. By keeping the old flowers cut off, the flowering season can be lengthened until late autumn. Finest mixed................................Pkt. 10c Campanula (Canterbury Bell.)*B. Cell shaped flowers. Wonderfully showy in beds or borders, and fine for cutting. Colors of white, rose, blue, and purple mixed.

Candytuft *A. Showy, branching plants twelve to fifcearing in profusion terminal clusters of beautiful, single cruciform flowers in a wide range of colors. Considered indispensable for cutting and very effective in beds, masses or rockeries. Mixture ..................................Pkt. 10c Hyacinth-Flowered-White, $1 \mathrm{ft}$. Fine for cutting ............................................... Pkt. 10c Carnations Marguerite Mixed."A. tains all of the various colors of the Marguerite variety - pink, white, and scarlet. These very popular favorites are valuable for culture in the open ground in summer and for pot culture in winter. Seeds sown in the spring will, by August, produce plants that will be full of bloom, until frost takes them; or they may be cut back, potted, and carried over winter in a cool room.

Centaureas (Cyanus, Corn-flower, Two feet Very Bachelor's Button.)*A. 
easiest culture; one of the most graceful of all. Sow early in the spring in the beds where they are to bloom. Thrives well in poor soil. Mixed colors......Pkt. 10c

Imperialis (Sweet Sultans.) *A. 1 to 2 ft. These are undoubtedly the finest of all Centaureas for cut flower purposes. The sweet-scented, artistic shaped flowers are borne on long, strong stems, and when cut will stand for several days in good condition. It is best to sow seed very early in the spring. Mixed colors.

Pkt. 10c

\section{Chrysanthemums *A. Annual} varieties.

The hardy annuals are summer-flowering border plants and quite distinct from the hardy perennial varieties often referred to as painted daisies.

Annual Single Mixed (Painted Daisies.) Many colors. Pkt. 10c

Evening Star (Single.) A splendid variety for cutting, flowers 3 inches across, of pure golden-yellow; in general appearance resembles the Yellow Paris Daisy.

Pkt. 10c

Northern Star. Pure white, with canary-yellow zone around a dark brown eye. ....................................................... 10

The Sultan (Single.) Crimson maroon.

Pkt. 10c

Coreopsis (Lanceolata Grandiflora.) *P. This is one of the finest of hardy plants, with large, showy, bright yellow flowers produced in the greatest abundance from June till frost. Easily grown from seed, flowering the first year if sown early.

Pkt. 10c Cosmos (Early Flowering.)*A. From and afterwards transplanted into light sandy soil, the plants will be 3 or 4 feet high by August, and will bear brightcolored, daisy-like flowers until frost. Mixed

Pkt. 10c

Early Flowering Double. Ever since the introduction of the Double Cosmos, we have been working to get this valuable flower in the early type and have at last succeeded in obtaining it. They grow to a height of about three feet, forming a perfect bush massed with bloom, bearing beautiful double flowers of good size on long stems. This strain comes about seventy-five per cent double from seed. Seed sown the latter part of April will be in bloom by July and continues till cut down by frost...........Pkt. 25c Delphinium *P. Five to six feet. fine flower is coming into favor. It is hardy, grows easily, has a long period of bloom, and gives to the garden one of its stateliest plants.

Gold Medal Hybrids. These magnificent Hybrids produce splendid spikes of very large flowers, single, semi-double, and

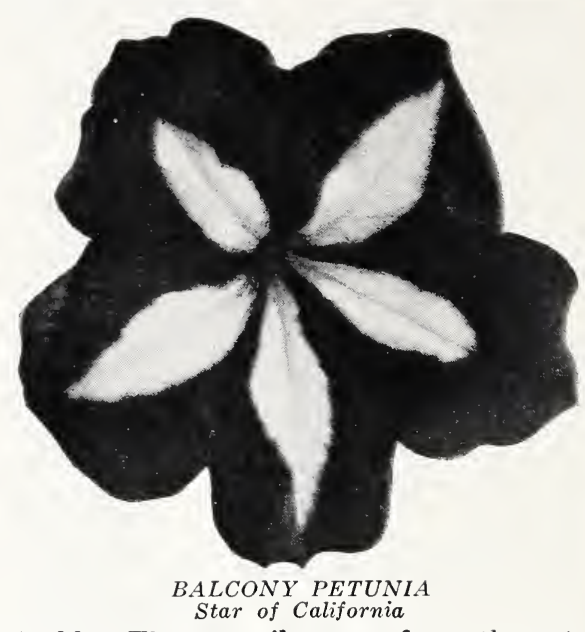

double. Flower spikes are from three to five feet in length. Colors range from pure white through all tints and shades of blue and lavender.

Pkt. 15c

Dianthus or Pinks (Kunderd's Double "Brilliant" Mixture of splendid mixture contains the cream of the Dianthus family. White and dark crimson selves, also white tipped light purple and shades of red with darker blotchings. A mixture of double and single pinks unsurpassed in variety of brilliant coloring and marking; desirable for cutting.

Pkt. 10c

Eschscholtzia (California P opsi-a. A low growing, very pretty annual with bright colored flowers and feathery foliage blooming freely all summer.

Ballet Girl. A beautiful carmine, shading to creamy white. Pkt. 10c Golden West. A clear yellow......Pkt. 10c Single Mixed ...............................................Pkt. 10c Four o'Clock *A. L a rg e and ioned plants of erect, bushy habit, which produce in profusion a succession of brilliantly colored tube shaped flowers, that open about four o'clock in the afternoon, remaining open all night and usually are closed before noon the next day. The flowers are red, white, yellow, or are striped and blotched in shades of these colors. Very desirable for borders, along a wire fence, or as the background of a flower garden, blooming during the late summer and autumn. Finest mixed.

Pkt. 10c, 3 for 25c

Gaillardia *P. Hardy perennial, year if seed is planted early.

Kelway's New Hybrids. Striking combination of orange and scarlet. Blooms until frost. Fine for cutting...........Pkt. 25c 
Annual Varieties (Single). Mixed colors …......................................................... 10 Gypsophila (Baby's Breath.)*A. Gypsophila Dainty white flowers. Blooms in such profusion as to produce a mistlike effect. Valuable for trimming bouquets

Pkt. 10c

Gypsophila (Panticulata.)*P. P u re white. Plants make fine clumps for garden use. Perennial............................Pkt. 10c Helichrysum (Straw Flower.)*A. Large, full, double daisylike flower heads with prominent centers and stiff, overlapping scales, produced in various shades of bright-yellow and scarlet, on stems of good length. The most popular of the so-called Everlasting Flowers, to dry for winter decorations. For this purpose the flowers should be gathered when on the point of expanding. Sow early in spring; thin to one foot apart each way. Hardy annual; two to two and one-half feet high. Finest mixed colors

Hollyhock

Pkt. 10c Hollyhocks make a fine row in a garden, a fine background next to a building, or high wall or fence. The double varieties are the most desirable, but the newer, semi-double, fringed types are also very popular. Seeds of the double varieties sown before mid-summer will insure fine plants the following season. Sow the seed one-half inch deep. Hollyhocks need a rich, well cultivated soil. If troubled with rust, spray freely with Bordeaux Mixture. May be used for cut flowers if the ends are charred over a flame as soon as cut. Choice double mixed

Pkt. 10c

Kochia (Summer Cypress and often (alled Mexican Firebush.) *A. Kō'-ki-a. Two or three feet. Makes a pyramidal-shaped cypress-like bush with feathery, light green foliage, deepening until it becomes a lovely crimson hue about September. Childsii. Excellent for hedges along garden walks......Pkt. 10c

Kunderd's Cut-Flower Mixture. mixture of seeds of hardy annuals, blended to give a continuous succession of beautiful cut-flowers from early summer until late fall. Cut-flowers are much needed for decorative purposes in the home and this mixture will supply different forms and new colors daily during the season. The seed may be sown in the flower garden or better, in rows where the plants can be more easily cultivated and the frequent cutting will not be so noticeable. The more you cut the more you may have to cut if no seed pods are allowed to form. Do not sow the seed too thickly, the plants should average 10 in. to 12 in. apart, the seedings should be thinned out and may be transplanted to other parts of the garden.................................................... 15 c Larkspur *A. 18 to 30 in. These Hyacinth-flowered with their long narrow, spikes as well as those of branching or candelabra habit. Sow seed $1 / 4$-inch deep as early in spring as possible where they are to bloom. Thin out plants to 12 inches apart. Plant little groups in the garden, making attractive spots of color all through the summer and fall. Fine for cutting.

Branching. Mixed Pkt. 10c

New Giant Hyacinth Flowered. A superb class. Mixed................................ Pkt. 15c Tall Rocket. Long showy spikes.

Pkt. 10c

Marigold *A. No flower-garden this fine, old-fashioned garden plant with its brilliant display of yellow and orange, both tall and dwarf sorts, and with finely cut, bright-green foliage. The African varieties are tall, usually one and one-half to three feet, and are well adapted for large beds, backgrounds of mixed borders, while the French are more dwarf and are often used for borders and pot culture as well as bedding.

El Dorado. Orange, yellow..........Pkt. 10c

Dwarf French, Finest Mixed.......Pkt. 10c

Tall, Double African Mixed..........Pkt.10c

Tagetus Signata Pumila. Is an attraetive, shrubby little plant growing about 10 inches high with fern-like foliage and small clean-cut golden yellow flowers. For low-growing borders try combining with Ageratum, Mignonette, Bachelor's Buttons or any other loose-growing low plant of a color that combines well with yellow. Avoid planting closely, which gives an appearance of too great solidity to the border.

Pkt. 10c

Marigolds deserve a place in every garden.

Mignonette * A. A well-known, ducing dense coneshardy annual, promade up of thickly set florets of modest colors. It is often used for cutting to combine in bouquets with other pretentious flowers lacking its delicate and pleasing fragrance. Seed is usually sown outdoors after danger of frost is over and if sown at intervals in spring and early summer a succession of bloom, under favorable conditions, is assured till late frost. Well pulverized soil, preferably light, sandy loam, should be used and the seed covered one-fourth inch deep................................. 10c, 3 for 25c Nasturtium - Kunderd's Premier Nasturtim Mixture of Tall Nasturtiums.*A. A gorgeous mixture. It contains all the new Giant flowering plants. A diversity of rich colors and

\section{A. E. Kunderd, Goshen, Indiana}


new and striking combinations is found in this mixture. A row in full bloom is truly gorgeous, containing every shade and tint of yellow, rose, scarlet, orange, carmine, violet, purple, lemon, bronze, maroon, ruby, cream and pink, both in solid colors and mottled and striped in many ways..................... 10c, 3 for 25c

Kunderd's Premier Mixture of Dwarf or Tom Thumb Nasturtiums-Will give a larger variety of colors in even proportions than any other Nasturtium mixture, for it is put up from named sorts, and also contains a large share of the Lilliput Nasturtium and the dwarf Chameleon, which have the richest and most varied combination of colors ever produced

Pkt. 10c, 3 for $25 \mathrm{c}$

Pansies *A. Seed sown in shallow Pansies boxes in the house, or preferably, in a cold frame where one is available, will produce fine flowers in summer and all through the fall. If the seed is sown in spring, outdoors, in a partially shaded location, the seedlings will bloom in autumn. The plants, if given a slight protection of leaves, usually come through the winter unharmed. Take care of the weakest looking seedling's, as they usually give the finest flowers.

Masterpiece-Petals curled and twisted. Very large flowers more or less blotched and in combinations of colors. The nearest approach to a double pansy.....Pkt. 15c

Bedding Mixture-A pretty strain. The flowers are smaller than those grown from our other mixtures but there are more of them.

Pkt. 10c

Giant Mixture-Made up from and including seeds of all the Giant Flowering Pansies, and several other sorts not otherwise obtainable than in this mixture................................... 15c, 2 for 25c Petunia *A. No bedding plants Petunia make a more pleasing display than petunias. The distinct colors and markings make a brilliant show. The plants make a strong growth and bloom profusely until after hard frosts.

Rosy Morn-The favorite window-box petunia, also fine for bedding. Delicate pink with white throat.................... 10c

Single-A desirable flower for bedding or for porch or window-boxes. The seed is very fine and needs only a slight covering. Plant in a warm, open location. I am offering a mixture of the best large flowering varieties in many beautiful colors

Pkt. 15c

Balcony Petunias*A. A very beautiful kind of Petunia. It grows more erect than the ordinary variety and the flowers are large and fine.

Balcony Blue-A rich, velvety, indigo blue

Balcony Crimson
Balcony Queen-A charming variety. Violet and white........................................Pkt. 20 c Balcony Rose - Flower's of brilliant rose-pink .............................................

Balcony White-Pure white form of this type ..................................................Pkt. 15c Balcony Mixed …................................Pkt. 15c Phlox *A. The annual Phloxes are dazzling in effect, particularly so when sown in masses or ribbon beds of contrasting colors. Few flowers are so easy to grow from seed, so pretty and compact in habit, so quick to bloom, or give such a brilliant display of color. Finest mixed colors............................... 10 c Poppy *A. Poppies should be sown as early in the spring as possible where they are to remain, as they do not stand transplanting. Mix the seed with dry sand and sow very thinly. If they come up too thickly they must be thinned out to stand five to six inches or more apart if you wish best results.

Double-Peony flowering, shrimp-pink. A bed of these tall, stately poppies should have a place in every garden. The flower's are extremely double and under favorable conditions as large as to resemble beautiful pink peonies.

Pkt. 10c

Iceland Poppies (Papaver Nudicaule). *P. While these are hardy perennials, they flower the first year from seed, blooming almost as early as the annual sorts. They are of graceful, neat habit, with bright green, fern-like foliage, formed in tufts, from which issue slender stalks about 12 inches high, bearing their brilliant flowers in endless profusion; most useful for cutting, for which purpose pick when in bud. They remain evergreen throughout the Winter.

Mixed Iceland Poppies.................... Pkt. 10c

Shirley Poppies.*A. These are single and occasionally semi-double, and range in color from the purest white through the delicate shades of pale pink, rose and carmine to the deepest crimson and bloodred, while many are daintily edged and striped. In fact, so varied are they that scarcely any two flowers are exactly alike Pkt. $10 \mathrm{c}$

Single Poppies. Mixed colors.....Pkt. 15c

Poppy Oriental (Papaver Orientale.) *P. From the middle of May until the end of June there is probably no flower in the garden that gives more brilliance and beauty than the Oriental Poppy. These Hardy Perennials may be easily grown from seed and are becoming more popular each year. The seed that I am offering is select seed from the gardens of Dr. J. H. Neeley who is recognized as an authority on Oriental Poppies and whose collection contains all of the best varieties among which are the following: Beauty of Livermore, Trilby, Proserpine, Wurtembergia, Mahoney, Mrs. 


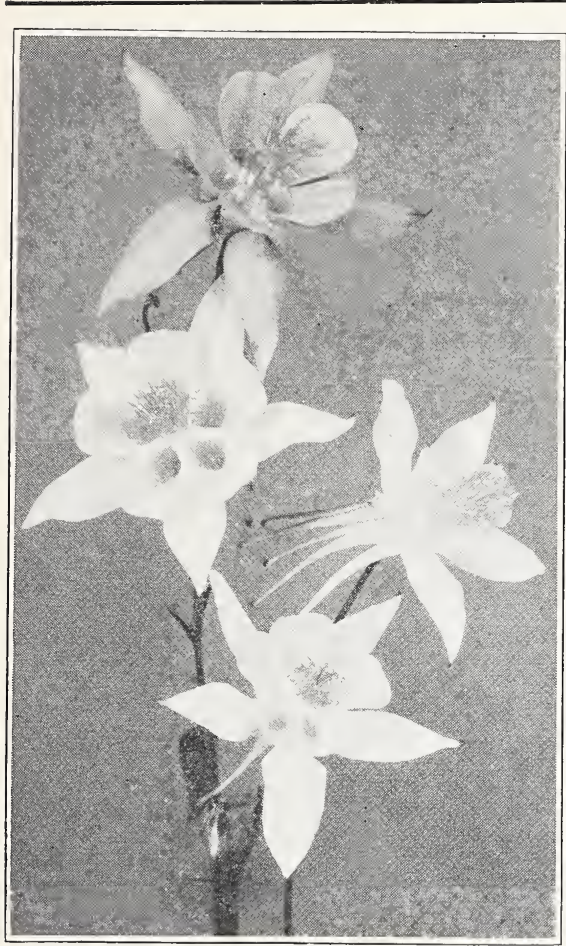

AQUILEGIA (Columbine)

Perry, Perry's White, Rembrandt and Lulu A. Neeley, which is his own production and is considered the equal if not superior to any that has ever been produced.

It will be understood that Poppy seed will not produce true varieties, nor can we expect them all to come true to color. Seed selected from the dark reds may be expected to produce a mixture of seedlings in which these colors will predominate. Seed selected from the white and pink varieties may be expected to produce a preponderance of those colors. While the mixed colors will contain a mixture in which the red and orange colors will predominate but may also have some of the bronze or mahogany colors, along with the whites and pinks.

Seed should be sown during the Spring or early Summer months to produce plants that will bloom the following summer. Cultural directions printed on seed packets.

Select seed from the above named choice varieties.

Per

Per $\quad 1000$

Pkt. Seeds

Dark or Blood Red Varieties...35c $\$ 1.00$

Pink and White Varieties..........35c $\quad \mathbf{1 . 0 0}$

Mixture of all colors.
Portulaca

(Sun Plant or Rose Moss.) * A. Por-tu-lak'-a. One of our finest hardy annual plants, of easy culture, thriving best in a rather rich, light loam or sandy soil, and luxuriating in an exposed sunny location; the flowers are of the richest colors, and produced throughout the summer in great profusion; fine for massing in beds, edgings or rockeries. There always appear single flowered plants among the best of double flowered seed. These should be weeded out as they show bloom.

Finest double mixed. Pkt. 10c Single Mixed-All colors..................Pkt. 10c Pyrethrum *P. Showy, hardy perennials growing 2 feet in height, with most brilliant and lasting flowers, sometimes called painted daisies; luxuriates in rich sandy soil and plenty of water, especially when in bud.

Hybridum. Double. Aster-like flowers, from pure white to crimson. Mixed.

Pkt. 20c

Salpiglossis *A. Sal-pi-glos'is. or border plants with richly colored, funnel-shaped flowers which are borne on long, graceful stems. The flowers of purple, scarlet, crimson, yellow, buff, blue or almost black are beautifully veined or penciled and are excellent for cut flowers. They are easily grown and are most desirable for beds or borders. Mixed.

Pkt. 10c

\section{Scabiosa}

*A. Ska-bi-os'a. Twelve to eighteen inches. This is an old favorite, and of late years has been greatly improved. The flowers are borne on long, wiry stems, in many beautiful colors. An exceptional garden plant and indispensable for cutting. Sow outdoors in May. Keep the seed-pods clipped and the plants will bloom much longer.

Azure Fairy-Blue ............................. 10 c

Peach Blossom-New pink.............Pkt. 25c

Shasta-New white ................................ 25t

Annual - Mixed double cone-shaped flowers in many rich colors borne on long stems. Very desirable for beds or for cutting. All colors mixed........Pkt. 10c Shasta Daisy (Alaska.)*P. Gracepure-white flowers with yellow centers; last a long time. Extra fine cut flowers.

\section{Snapdragons - -See}

Stocks *A. Giant Perfection or Cut proved strain of this old sweet-scented garden favorite. Flowers are more double and much larger than the ordinary stock. They throw out numerous side branches, all bearing double, fragrant 
flowers. Excellent for pots or for cutting. My mixture contains shades of blue, scarlet, pink and white...........Pkt. 10c

\section{Straw Flowers $\underset{\text { Helichrysum. }}{\text { See }}$} Sweet Peas "A. No garden is too sweet peas. The blooming season usually extends from early summer until very hot, dry weather and no other climber equals it for cutting, either for use in bouquets or for table decorations.

Nothing within recent years can approach in importance the introduction of the "Spencer, Butterfly or Orchid Flowered" sweet peas. They are distinguished from the standard sorts by the enormous flowers with crinkled and wavy petals, and also from the fact that they usually bear four blossoms on a long, stout stem.

America-White striped scarlet.

Pkt. 10c

Austin Frederick-A giant lavender.

Pkt. 10c

Commander Godsall-A very beautiful violet-blue Plit. 10c

Crimson King-A true ox-blood, a pure rich crimson. Very distinct..............Pkt. 10c

Dobbie's Cream-A deep primrose.

Pkt. 10c

Hercules-A choice soft rose-pink. Large flowers .................................................. 10 c

King White-No finer white, in every respect, has ever been produced...Pkt.10c

Miss California-One of the newer varieties. A very beautiful orange-salmon

Pkt. 15c

Warrior-An extremely large flower, maroon, almost black. Pkt. 10c

Youth-The most fragrant of all sweet peas. With an exquisite pink picotee on the large, pure-white ground

Pkt. 10c

Kunderd's Blue Ribbon Mixture-This mixture is a beautiful blend of only the largest and brightest colored Spencers. It includes all the standard Spencers of merit and all the very latest novelties, such as Austin Frederick Improved; Mrs. Tom Jones; Picture; Valentine; Royal Scot; Renown, etc...

Pkt. 15c

Kunderd's Premier Mixture of Spencers-Made up from the named varieties in this list and many other choice Spencers including those of recent introduction. Great care has been given in preparing this mixture, so that each packet will contain a balanced proportion of colnr Pkt. $10 \mathrm{c}, 3$ for $25 \mathrm{c}$

Sweet William "P. It is one of able for display in the garden. The plants are easily grown, hardy and free flowering. They produce a succession of flower clusters, thus affording splendid bloom for several weeks. The florets are handsomely colored and marked and are borne on stiff stems in great profusion, forming dense, round topped heads or clusters, often three to four inches across. The colors are exceedingly varied, ranging from white through many shades of rose, lilac, red, carmine, crimson, and maroon to nearly black, usually two shades to each plant. Double mixed.

Pkt. 10c

Single Finest Mixed-Very c hoi c e single-flowering varieties by many much preferred to the double.

Pkt. 10c

Verbena *A. This well-known annual of low growing, decumbent habit of growth is very desirable for massing in beds on the lawn. It is suitable also for borders and window boxes. Large clusters of showy flowers are borne in succession through a long season until frost. Each truss or cluster is about two or three inches across, and includes a dozen or more single flowers about three-fourths of an inch across, tubular with five spreading lobes. The length of stem and texture of the flowers make them of value for bouquets and table decorations. There is a wide range of colors, shades and stripes usually running from pure white to deep purple.

New Gigantea Type Luminosa-A bright-pink, shading to softer shade of salmon

Pkt. 35c

Rosea Stellata-Rose-pink, white eye.

Pkt. 25c

Violacea Stellata-Deep violet, white eye

Pkt. 25c

Gigantea Mixed

Pkt. 20c

"Wild Garden"s Flower Seed."A. A wide variety of hardy flowering annuals mixed together, and wherever planted will insure something new almost every day. Is suitable for sowing in shrubbery, and in beds on which no care will be bestowed, or even for sowing in exposed locations, where wildness is preferred to order and precision. Seed may be broadcast on soil clean from weeds. To those who cannot give the necessary care required in a neatly laid-out flower garden, the "Wild Garden" presents a good substitute. You will be well repaid in giving this a place in your garden.

Pkt. 10c

Zinnia *A. The Zinnia is one of the most brilliant, showy and satisfactory of annuals, and has long been a general favorite. The seed can be sown early in the hot-bed or light window and transplated, or sown later in the open ground. It spring's up quickly, and the young plants begin flowering early. 


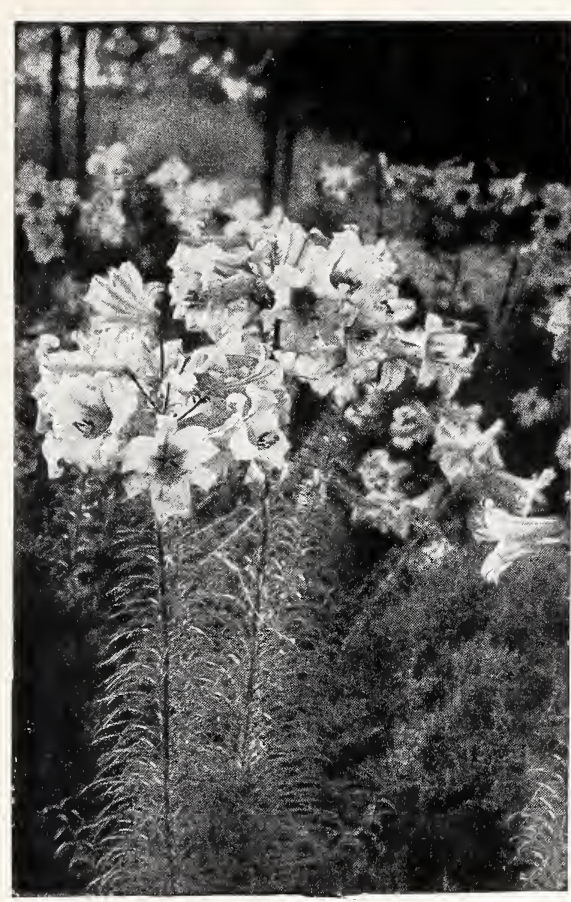

REGAL LILY

Giant Dahlia Flowered

Crimson Monarch-A splendid red of immense size, very showy....................Pkt. 25c

Dream-A deep lavender Zinnia of a most lovely color, combining delightfully with light rose and pink.

Pkt. 25c

Exquisite-A delicate light rose shading to darker rose at the center. It is a very beautiful flower.

Pkt. 25c

Gold State-A striking shade of burnt orange. The distinct color and size of the bloom places it among the choicest of our summer and fall flowers......Pkt. 25c

Oriole-A combination of orange and gold that makes one of the most attractive flowers. It changes slightly with age, but the color is always lovely.

Pkt. 25c

Polar Bear-A pure white, the result of years of hybridization. Deserving of a place in every garden. Pkt. 25c

Purple Prince-A fine deep purple.

Pkt. 25c

Scarlet Flame-A large flower of beautiful bright scarlet. A soft blending of orange through the petals enriches its beauty

Pkt. 25c

Giant Dahlia Flowered Mixture. A good mixture
Kunderd's Special Mixture-This mixture is extra fine and is made up of named varieties of the Giant Dahlia Flowered Types ...........................................Pkt. 25c

Kunderd's Giant Double Flowered Mixture Pkt. 10c

Lilliput-Zinnias-12 inches. When in bloom is a mass of tiny, double, ballshaped flowers about 1 inch in diameter. Very bright. Mixed.

Pkt. $15 \mathrm{c}$

Red Riding Hood-A beautiful little Pompome zinnia of dwarf habit of growth. Splendid for border. Brilliant scarlet flowers that bloom in profusion all summer Pkt. 10c

Salmon Rose-A new shade fine for cutting ............................................................. 15kt

Scarlet Gem - Golden Gem - White Gem Each per Pkt. 10c

\section{Regal rily \\ (LILIUM REGALE)}

This wonderful, new, hardy lily was discovered in China by the late Mr. E. H. Wilson, of The Arnold Arboretum, Boston, and is still but little known to the general public.

He tells of having seen it growing wild by the hundreds of thousands, exhaling its wonderful perfume, giving the air a delightful odor for miles around.

I have been so charmed with it that I am glad to be able to offer it to my customers. It grows to a height of from two to five feet with 3 to 12 and more massive blooms open at a time. Color a beautiful white with delicate, canary-yellow throat and a pinkish tint on the outside of the petals. It blooms in July and increases rapidly both from seed and bulb off sets. It is easy to grow from seed and will bloom the second year.

\section{Grow Regal Lilies from Seed}

This lily can be easily grown from the seed and is proving exceedingly popular as it is no doubt the finest of all lilies. I had scarcely enough to fill orders last year so please send your order early to avoid disappointment.

Seeds from the past season's crop are now ready at the following prices, prepaid:

Regal Lily Seeds-100 for 25c; 1000 for $\$ 1.50$.

\section{REGAL LILY BULBS}

Small blooming size.........20c ea. \$2.00 Doz. Medium size ............................30 ea. $3.00 \mathrm{Doz}$.

Large size ..................................40c ea. 4.00 Doz.

Largest size .............................50 ea. $5.00 \mathrm{Doz}$.

Orders for bulbs accepted now for delivery October, 1931. 
Laciniated Varieties....1 Plain Petaled Varieties p Primulinus Varieties.pr Ruffled Varieties Snapdragon Type

AMERICAN BEAUTY, ROSE COLOR, WINE RED, PURPLE, ETC.

Avantis, $p$

Beverly, p

Brilliant Sun, $\dot{p}$

Burlington, p

Burning Bush, p

Claude Bowers, p.

Color Beauty, p

Contrasta, $\mathbf{p}$.

Dixie Girl,

Dr. L. H. Bailey, r

Dr. Nelson Shook, r

E. C. Vick, $r$

Eighth Wonder, p

Fuld's Favorite,

Georgia, p.

Gloaming, $p$

Golden Rose, p

Graphic, $p$

Haughty, $p$

H. H. Goldstein, p

I mperial Chimes, $p$

Isolita, $\mathbf{p}$.

Louis F. Swift, $\dot{p}$

Lustre,

Masterpiece, $r$

Midas, $p$

Mrs. A. R. Erskine, p

Mrs. Arthur Meeker, p

Mrs. Chas. A. Stevens, p

Mrs. Geo. W. Moulton, p

My Self, p

October, p.

Old Rose, r

Opaline, p

Overture,

Pal O'Mine, p

Philatelia, p

Phyllis Cloetingh, pr.

Primgold, pr.

Prince Charming, $\dot{p}$

Purple Beauty, p.

Purple Crown, p

Purole Feather,

Purple Glory, r

Purple Queen, r

Ravenna, $p$

Red Ribbon, $r$

Red Rose, p

Reo, $\mathbf{r}$

Rosalind;

Rosemary Hayes, $r$

Royal Beauty, $p$

Salmon Ruffles, $r$

San Francisco, p

Sweet Cherry, p . . . 46

Taurus, pr.

Toledo, p

Tyrian Beauty, p. 72

Viola Gem, p. . . . . . 72

Violet Glory,

Violet Prince, p

William Booth, $p \ldots 73$

Yellow Frills, pr .... 75

\section{LAVENDER AND PURPLE} SHADES

Battle Creek, p.

Blue Isle, p

Blue Lily, p

Blue Orchid

Byron L. Smith, p 5

Cleo, p.

Elba, r

Elkhart, p

Fantasy, p
Glenn Banks, p... 39

Holy Grail, p.

Indianapolis, $r$

J. Oliver, $\mathrm{p}, \boldsymbol{c}^{\circ} \cdot{ }^{\circ}, 25$

Kasson, $\mathbf{r}$. 26

Kunderd's Wild Rose, r. $\quad 26$

Lavender America, p. . . 61

Lavender Beauty, 1. . . . 82

Lavender Frills, r. . . . . 14

Lavender Glow, p. . . . . 61

Lavender Pride, $\mathbf{r}$. . . . . . . 26

Lavender Rose, p. . . . . 61

Magic, p

Magnificent, p. . . . . 62

Mary Fennell, p . . . . . 62

Mary Jane, p. . . . . . 62

Mikail, $r$.

Moravian, $\mathbf{r}$

Mrs Geo, W. Hay,

Orchid Flower,

Petrella, p

Pres. Lincoln, p

Purple Challenge, $\dot{p} \cdot \cdot \cdot 66$

Purple Pansy, p. 67

Purple Progress, p . . . . 67

Purple Spot, p. . . . . . 67

Royal Purple, p . . . . . 69

Ruth Huntington, $r$... 29

Serene, p

Varro, pr

White Lavender,

Youell's Favorite, $r$

PINK IN ALL SHADES

A. E. Kunderd, $r$

Anlow, p. . :

Anthony B. Kunderd

Antonia Antonette, $p$

Arthur Brisbane, p.

A. T. De La Mare, p

Blanche Bollinger, $r$

Blushing Beauty, $r$.

Booth Tarkington, $p$.

Bridal Rose, r

Buckey,

Buena,

Carmine. B. Lipsner, p • 37

Cassiopia, pr.

Cattleya Rose, r . . . . 23

C. E. Stout, p

Chantry, p.

Charm, $r$

Col.

Crinkles, r. . . . . . . 23

Dainty Lily, p. . . . . . 3

Darling O'Mine, $\mathbf{p} \cdot . \cdot .38$

Delafern, p . • • • • . . $\mathbf{3} 8$

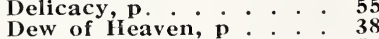

Dew of Heaven, p * · · $\mathbf{3} 8$

Dream Flower, p

Dr. David Griffith, p . . 55

Dr. Elkins, p. . . . 55

Dr. J. H. Neeley, $\dot{p} . *^{*} \cdot{ }^{-} \quad 55$

Ed Springer, p. . . . . 5

E. J. Shaylor, $\mathbf{r}$

Elrose, p.

Enchantress, pr . . . . 77

Estella, p. . . . . . 56

Evangeline Booth, $\mathbf{r} \cdot{ }^{\cdot} \quad 16$

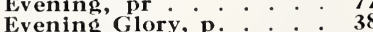

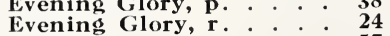

Fairie, p. . . . . . . 57

Fidelity, p.

Gene Stratton Porter, p.

Glory Flower,

Golden Pink, p

Goshen, p

Graf Zeppelin, p

Helen Keller, $p$

Highland Laddie, p

Hoosier Pearl, pr.

Indian Maid, p.

Intramura, $p$

J. J. Mitchell, p

Joanna Hill, r • . . . . . 14
June Moth, p \& • • . 40

Kunderd's Apple Blossom, $r$.

Lacinatus, 1

Lela, $\mathbf{r}$

Leopard, $p$

Lilac Glory, $\dot{r}$

Lorraine Cloetingh, pr

Marshal Foch,

Mary Carmichael,

Merton W. Wentworth, p

Metropolis, $p$.

Millionaire, $p$

. 63

Modern Beauty, p : : : 41

Modesty, p. . . . . . 63

Mommie Dietz, p. . . . . 63

Mrs. Dr. Norton, p. 63

Mrs. Frank Pendleton, $p$ : 64

Mrs. J. C. Bruggen, p. . . 63

Mrs. Laurance Armour, r 14

Mrs. Paul Dieball, p . . . 63

Mrs. Sam Spohn, p. 41

Mrs. Walter Lytton, p : . 64

Muncie, p. . . . . . . 34

Nightingale,

Northern Light, p : : : 41

Odyssee, p

Oh Promise Me, pr : : 75

Opal, pr...... . . . 79

Ophelia, r. . . . . . $\quad \begin{aligned} & \mathbf{1 6} \\ & \text { Oran }\end{aligned}$

Oran, r $: \therefore: \therefore: \quad 27$

Palmetto, p. . . . . 65

Pansy Flower, p. . . . 42

Paramount, p. . . . . 65

Patricia Carter, pr. : : 79

Pauline Kunderd, $p: 0^{\circ} \quad 65$

Peach Blushes, p. . . . . 34

Peach Bud, p. . . . . . 42

Peach Glow, p. : $: \because: 42$
Peacock, p. 42

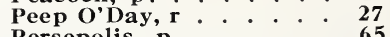

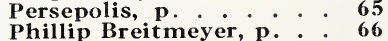

Pink Beam, p. . . : : 65

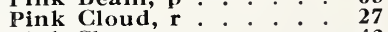

Pink Clover, $p$. . . . . . 43

Pink Delight, p. . . . . . 65

Pink Enchantor, p. . . . 66

Pink Favorite, $p$. . . . . 43

Pink Feather, r . . . . . 43

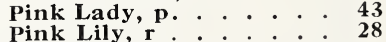

Pink Pansy, p : : : : 66

Pink Pencil, $r: \vdots: \therefore 19$

Planada, p. . . . . 66

Pompeian Beauty, p . . . 66

Pond Lily, p. . . . . . . 66

Pretty Pink, p. . . . . 67

Primora, r. : . : 28

Proud Feather, p. . . : 43

Regal Beauty, p. . . . . 34

Rhapsody, p. . . . . . 69

Rose, p . . . 69

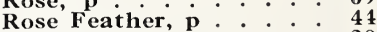

Rose Glory, r. . . • • . 28

Rose Pendleton, p . . . . 44

Rose Splendor, p. . . . . 45

Rozan Marie, p . . . . . 34

Ruffled Splendor, $r$. . . . 28

Ruth Field, p... . . . 69

Salmon Fins, p. . . . . 45

Salmon Star, p. . . . . . 70

Sammy Lane, p. . . . . 45

Shell Pink, pr. . . . 80

Smiling On, $r$. . . . 19

Snowy Morn, p. . . . . . 46

Spectrum Beauty, p . . . 46

Stippled Beauty, pr . . . 80

Stuart Merrill, p. . . 46

Sunrise, p. . . . . $\cdot 46$

Sweet Rose, p . . . . 71

Symbol, p . Weston, $\mathbf{p}: \therefore: \quad \mathbf{7 1}$

T. A. Weston, p... $\quad$\begin{tabular}{l}
71 \\
\hline
\end{tabular}

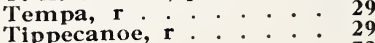

Tonopah, p . . . 72 
Treasure, $p$

Trianon, p.

Twilight, $r$.

Tyrian Rose,

United States, $p$

Virginia Hale, $p$

Virginia Lou, pr.

Wawasee, p William Randph

Wonderful, $p$

\section{RED FROM BRIGHTEST TO} DARKEST SHADES

Achillas, p.

A-Flame, $p$.

Al. Smith, p

Ashburn, p

Athene, pr.

Autumn Colors,

Babylon, $p$.

Big Black, p

Black Feather, p

Black Pansy, p.

Cardinal Prince,

Challenger, $p$

Chancellor, p

Charles F. Fairbanks, $\dot{p}$

Cherry Rose, p.

Chicago, r.

Circe, p . .

Color Marvel, $\mathbf{r}$.

Colors, p

Coming Joy, $\mathrm{p}$.

Contemplation,

Coral Pink, r.

Darkest, p.

Duchess, $p$.

Ecstasy, $p$.

E. T. Barnes, p

E. W. Allis, p.

Fairmont, p

Fairview, p.

Fairy Maid, p

Fire Glow, $p$

Fire Pink, p

Fire Ribbon, p

Fire Torch,

Flame of Fire, $p$

Flaming Vale,

Gay Feather, p

Golden Brown, $r$.

Gordon L. Pirie, p

Gorgeous, p

Gov. Hanly, p

Harmonia, $r$.

Herald, p

Hermes, $r$

Hugo Eckener,

Hyperion, 1 .

Ida Van, $p$.

Imperiu m, $p$

Indian, $\mathbf{p}$

Indian Chief,

Intensity, $r$.

Iroquois, p.

Jacelia, p

J. Harry Seiz, p

John Dunbar,

John T. McGutcheon, $p$.

Joseph J. Lane, p.

Leonard Barron, $p$

Lexington, $p$.

Little Red'Star

Mahogany King, $p$.

May Day, p

Melody Maid, p

Me Too, p

Midsummer Dream, pr.

Midway, p.

Mischief, $p$.

Miss Universe,

Monnie, $p$.

Orange Fire, $\mathbf{r}$

Orange Fires, $r$

Orange Gold, p.

Orchidian, $p$

Predominator,

Prof E H Wilsor

Proud Lily, p 43

Quartin Dillon, $\dot{p}:{ }^{\circ}$

\section{MISGELLANEOUS}

Why Kunderd Gladioli Stand Supreme Endless Uses of the Gladiolus

World's Recognition of Kunderd Gladioli

Why Kunderd Gladioli Represent the World's Greatest Value

Why I List Only Kunderd Originations

Reward for Early Orders

How to Order.

1931 Ruffled Introductions . . . . . . . . . . . . . . . 14

Same in Special Collection Offers . . . . . 15

1930 Ruffled Introductions 16

Same in Special Collection offers : . . . . . : $: 21$

General Ruffled List. . • . • . . . . . . . . 22

Same in Special Collection Offers ........ 30

1931 Plain Petaled Introductions.

Same in Special Collection Offers . . . . . . . . . . . . . 35

1930 Plain Petaled Introductions. . . . . . . . . . . 36

Same in Special Collection Offers . . . . . . . . . . . . 47

General Plain Petaled List .

Same in Special Collection Offers . . . . . . . . . . . . 74

New Primulinus Introductions . . . . . . . . . . . . . . 75

Same in Special Collection Offers . . . . . . . . . . . . . 75

Game in Special Collection offers $\cdot \cdot \cdot \cdot \cdot \cdot \cdot \cdot \cdot \cdot \cdot \cdot 76$

Lacinia ted Gladioli

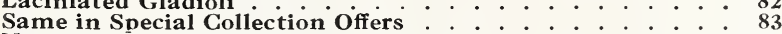

New Snapdragon Gladioli

Gladioli in Mixture .

How to Plant and Care for Gladioli ${ }^{\circ}$. . . . . . . . . 86

Flower Seed Department 00

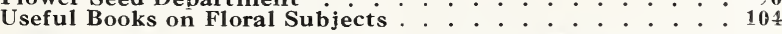

Rajah, p.

Red Beauty, p.: : : 4

Red Butterfy, p : $: \therefore 6$

Red Cardinal, $\mathrm{p}$

Red Cherry, p 68

Red Commander, $\mathrm{p}: \vdots: \quad 68$

Red Copper, $p$. : : 68

Red Darling, p. . . . : 68

Red Empire, p. . . . . . 68

Red Fire, $p$. 68

Red Mahogany, p: : : 34

Red Orange, pr. . . . . . 79

Red Roamer, p. . . . : 6

Red Rock, $p$ 44

Red Splendor, $\mathbf{r}$. . . . . 28

Red Torch, p. . : : : : 34

Red Velvet, $p$

Remarkable, $p$

Dr. R. L. Starkweather, p. 56

Emblem, p. . . • . 56

Gaiety, p. . . * * 56

Happy Heart, p : 39

Herbert Hoover, $p$

I Excel, $p$

James M. Sheldon, p. : 32

J. Ogden Armour, r. . . . 25

Mahogany, p. . . . . . 40

New York, $\mathbf{r}$. . : : 27

Oracle, p. . . . . : 34

Quantico, r . . . . . 28

Red Charm, p. 68

Red Cloud, p. 68

Regulus, p. : : : 69

Show Flower, p . . . 70

St. Thomas, p . . . . . . 71

Robinette, $p . \cdot 0^{\circ} \cdot 6$

Robt. J. Kunderd, $\dot{p}: \vdots 69$

Rolling Prairie, p. : : 44

Rosea, p. . . . . . 64

Rose Exquisite, p. . . . . 69

Rose Pearl, p.

Rosy Glow, p. . . . . . 69

Rosy Smoke, p. : : 69

Royal, p. . . . . . . . 69

Scarlet Glory, r. . 29

Scarlet King, p. . . . · · 70

Scarlet Princeps, p. . . . 70

Scarletta, p $\dot{0} \cdot \dot{70}$

Senator Beveridge, p * * 83

Spangled Beauty, $p .:{ }_{46}$

Splendor, $p$

sun Rest, p

Temblor, pr . . . . 80

Thomas A. Edison, r . 29

Tiger King, p. . . . . : 46

Torpedo, $p$. 34

Turkey Run, p. : . : . 47

Uhlan Chief, p. . . . . . 72

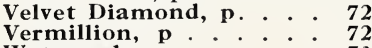

Watermelon, p. . $\cdot \cdot \quad 73$

\section{RED WITH LARGE THROAT MARKINGS}

Agnes Ball,

Ambrosia, p . $\quad 31$

Anthony Zonker, p.: 48

Beauty Flower, p. 49

Bobby, p. . . . 50

Bright Spot, p : 37

Dominus, p 55

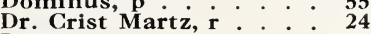

Dream, r.

\section{SMOKY SHADES}

Copper Bronze, pr . . . . 76

John T. Pirie, p . . . . . 61

Loella, p. . . . . 61

Orient, p. . . . . . . . 64

Polychrome, p. . . : 66

Romance, p . . . . . . 69

Ulyser, p $\cdot \dot{p}^{*} \cdot \cdot \cdot$

\section{SALMON, ORANGE,} SAFFRON, ETC.

Alice Tiplady, pr. . . . . 76

Altair, pr . . . . . . . . 76

Alton, $\mathbf{r}$. . . . 22

Arthur Cowee, p.: : 36

Blushes of Cream, p : . 49

C. C. Sherlock, p. : : 50

Cheerio, p . . . . . 37

Clarise, p $\quad 37$

Classic, $\mathbf{r}: \cdots$

Commander Byrd, $\dot{p}:: \quad 31$

Dainty Orange, pr . . . . 76

Dorothy Dick, p . . . . . 32

Excellence, p $: \cdots$

Favorite, r. . . 24

For You, p. . . . 38

Golden Ark, pr

Golden Fringe, p Golden Gleam, pr : : $\quad \mathbf{5 8}$

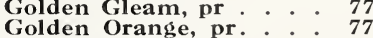

Grand Glory, p. pr : : 59

Good Morning, $r \quad$. . . 16

Gov. Emmerson, p . . 39

II. II. Groff, $p$. . : 39

Immensity, $p$. . . . . 60

J. Horace McFarland, p. 60

.


Julius Rosenwald,

Juno, $\mathbf{r}$

Kilima, p . . . .

King of Oranges, pr

Leen Wone, pr

Lilith, $r$

Magnifica,

Meadow Lark, $\mathbf{r}$

Ming Toy, pr

Morning Sunshine, $r$

Mottled Feather, p

Natalie, $r$

Opal Fringe, p

Orange Feather, $r$

Orange Giant, pr.

Orange Glow, p.

Orange Lily, r

Orange Plume, p

Orange Salmon, pr.

Orchid Butterfly, r

Ozone, pr

Pride of Goshen, $r$

Queen of Orange, $p$

Roman Candle, p

Rose Ann, p.

Saffron King, pr

Salmon Buff, pr

Salmon Plume,

Silph, p

Song of the Lark, $r$

Southern Beauty, $r$

Spirit of '76, $p$

Sun Glow, p.

Sweeter Seventeen,

Tanager, $r$

Today, pr

Ulrica, pr

Weesie, p

Wonderland, pr

Zona, pr

\section{WHITE AND WHITE WITH} LIGHT MARKINGS

Anna Mae, $p$

A. R. Cole, p

Avalon, $r$

Baby Blushes, $p$

Blushes,

Break O'Dawn, p

Chalice Flower, $r$

Fairest Pearl, p

Fairest White, p

Fern Kyle, $r$

Fiancee, $p$

Florence Winter,

June Night, p

Marie Kunderd, $r$

Mary Pickford, p

Miss U. S. A., p

Mountain View,

Mrs. Dr. Bevan, r

Polyhymnia, pr

Prof. C. S. Sargent, p

Silver Comet, p

Smiles,

Snow Boy, p

Snow Flake, p

Snow Glory, $r$

Sprinkle, $r$

White Butterfly, pr

White Glory, r

White Pigeon, $p$
WHITE WITH LARGE

THROAT MARKINGS

Adair, 1

Maimonides, $\mathbf{r}$

Pantheon, p

Promise,

White Feather, p

comb, p

\section{YELLOW, BUFF, CREAM, ETC.}

Achievement,

14

Ah, p 48

Antoine, $\mathbf{r}: \cdots$

Aquila, 1

Arcturus, $r$

Atreus, $p$

Beauty Wave, r

Brown Lily, $r$

Butterboy, pr

Butterfly, pr

Canary Feather, $r$

Comet,

Country Gentleman, $r$ : 16

Cream Cups, p . . . . . 31

Cream Puff, $p$

Cygnus, pr

Cyprian, $\mathbf{r}$

Encore, pr

Fawn Gold, p

Fimbriatus, 1

Glorious, r

Gold Star, p

Golden Apricersary, $r$. 24

Golden Beauty, $r$.

Golden Buff, p

Golden Frills, pr

Golden Glory, $r$

Golden Harmony, pr

Golden Light, pr

Golden Robes, $r$

Golden Salmon, $r$

Golden Snapdragon, $s \cdot{ }^{*}$

Golden Tinge, pr. . . . : 77

Golden Victor, pr $: \vdots^{\circ} \quad 77$

Hestia, p.

Impresario,

Interlude,

Jap, pr

J. F. Rosenfield,

Kunderd's Yellow

Favorite,

Kunderd's Yellow

Wonder, $p$

Kunderdii Glory, r

Lemon Blushes, p

Lewis E. Gary, p

Lily of Gold, $r$

Little Doll, 1 .

Love Song, p

Lullaby, pr

Luxury, p

Marigold, pr

Melody, pr

Miss Bloomington,

Mongolia, pr

Mrs. Calvin Coolidge, pr

Mrs. E. A. Hamill, p.

Mrs. John T. Pirie,

Ne Plus Ultra, r

Orangine, $p$

Otto Carmichael, r
Paladin, pr 79

Pasteline, pr . . . . . . . 79

Pierian, 1 p 83

Primrose Beauty, p . . . 67

Ramona, pr ..... . 79

Silver Cloud, p : . : 45

Star Lily, $\mathbf{r}$. . . . . . . 29

Sulphur Frills, r . . . . 29

Sulphur Glow, r . . . . 29

Syncopation, pr .... 80

Wonder Glory, $\mathbf{r}: \cdots 20$

Yellow Prince, pr : . : 81

\section{COLOR ILLUSTRATIONS}

Baby Blushes

Blue Isle

53

C. C. Sherlock

Chas. F. Fairbanks

Inside Front Gover

Chicago 87

Coral Pink. . . . . . 53

Dr. J. H. Neeley
Dr. Nelson Shook

Emblem . Inside Front Cover

Evening Glory

Favorite. Inside Front Cover

Fern Kyle ........ . 54

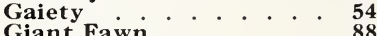

Glorious $\cdot \cdot \cdot \cdot \cdot{ }_{51}$

Graphic：：：：１7

Highland

Laddie. . Inside Front Cover

I Excel

Immensity. . . . . . . . 18

Joy 88

King of Oranges : : : 18

Lilac Glory 88

Loella . . Inside Back Cover

Lustre . . . 54

Marigold. Inside Back Cover

Mary Jane . . . . • • 51

Miss Bloomington

Mrs. Arthur Meeker : : 17

Mrs. Chas. A. Stevens : : 52

Mrs. Dr. Norton . . : $\mathbf{5 4}$

Mrs. Frank Pendleton . 17

Mrs. Geo. W.

Moulton. Inside Back Cover Oran

Paramount

Pauline Kunderd. . . . . 18

Philatelia 87

Purple Queen : . 88

Rajah . . Inside Front Ċover

Red Fire . . . . . . . 51

Romance .. . . . . . 53

Rose Glory : . . . . 51

Rose Pearl

Ruth Huntington

Shell Pink • Inside Back Cover

Splendorra

Sulphur

Frills Inside Back Cover

Thos. A. Edison . . 87

Tiger . . Inside Front Cover

Twilight . 18

Tyrian Beauty : : : 87

Violet Glory . . . . : 87

Wild Rose

\section{USEFUL BOOKS ON FLORAL SUBJECTS}

The Gladiolus, by F. F. Rockwell

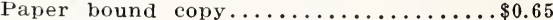

Garden Guide

Paper bound copy..............\$1.15

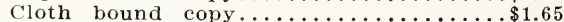

1001. Garden Questions Answered, by Prof. Alfred C. Hottes

Paper bound copy.............\$1.65

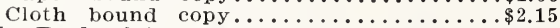

The Book of Annuals, by Prof. Alfred C. Hottes Cloth bound copy ........\$1.65

Fertilizers for Greenhouse and Garden Crops, by Alex Laurie and J. B. Edmond

Cloth bound copy..............\$2.15

Rock Gardens, by F. F. Rockwell

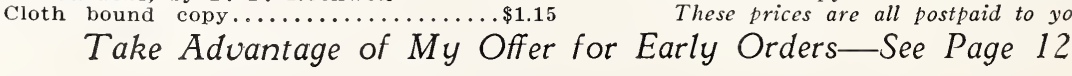

The Book of Perennials, by Prof. Alfred Hottes

Paper bound copy............\$1.65

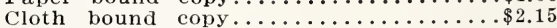

The Woman's Flower Garden-Indoor and outdoor, by Jane Leslie Kift

Paper bound copy............\$1.10

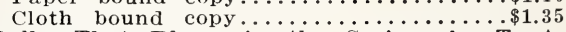

Bulbs That Bloom in the Spring, by $T$. A. Weston

Paper bound copy.............\$1.65

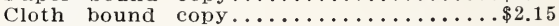

The Principles of Flower Arrangement, by Prof. E. A. White

Cloth bound copy ...........\$3.15

These prices are all postpaid to you. 


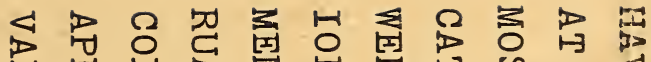

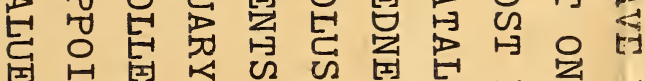

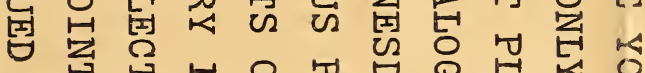

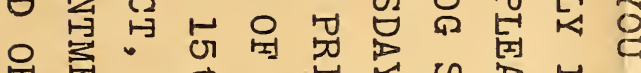

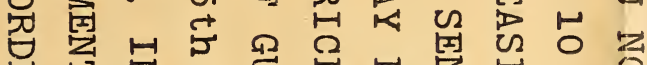

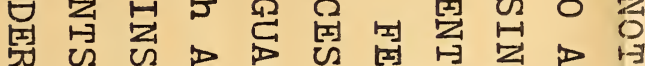

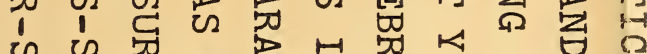

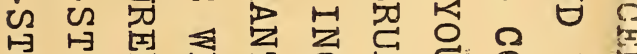
0 O

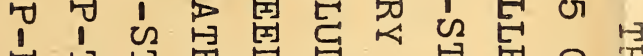

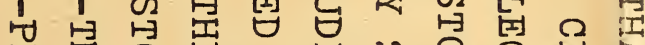

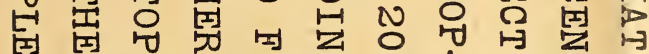

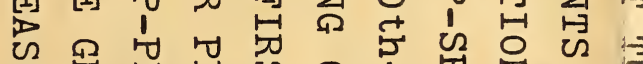

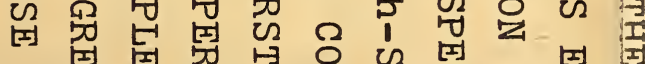

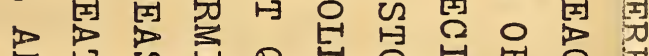

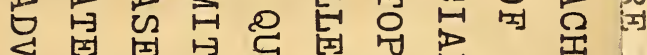

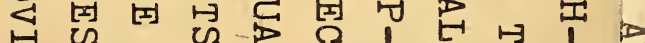

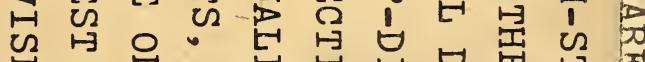
玨

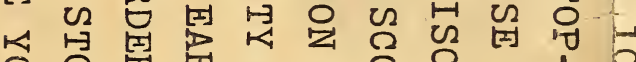
O 0 ॠ

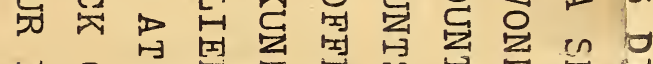

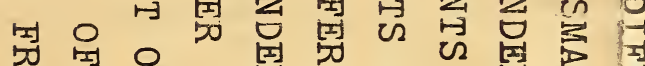

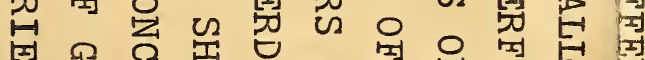

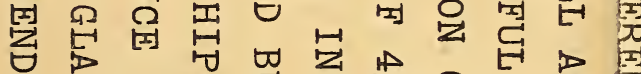

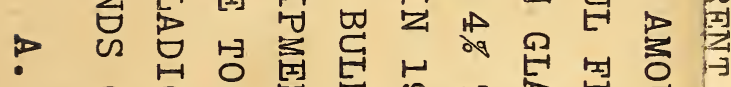
ख

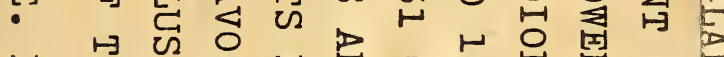

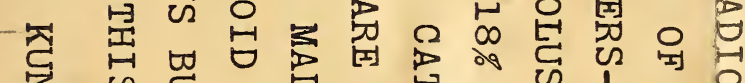

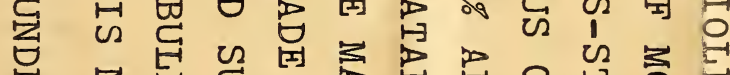

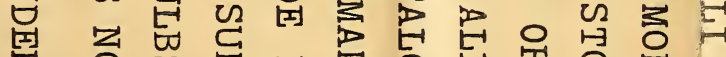
刃

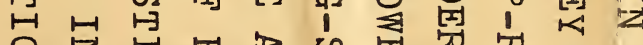
¿ Z

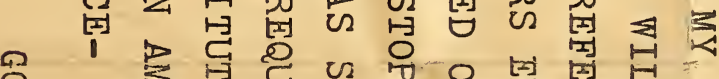

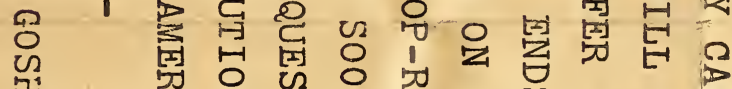

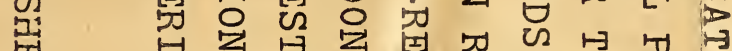
펌 H

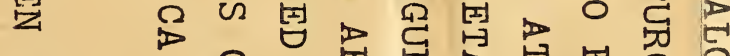

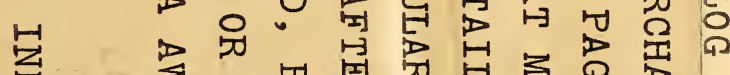

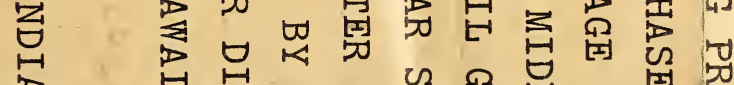

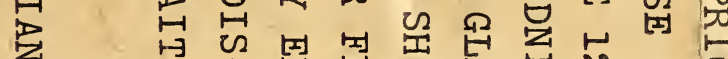

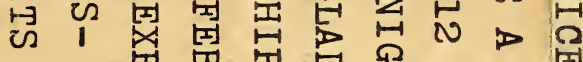
出 11 要 0 四

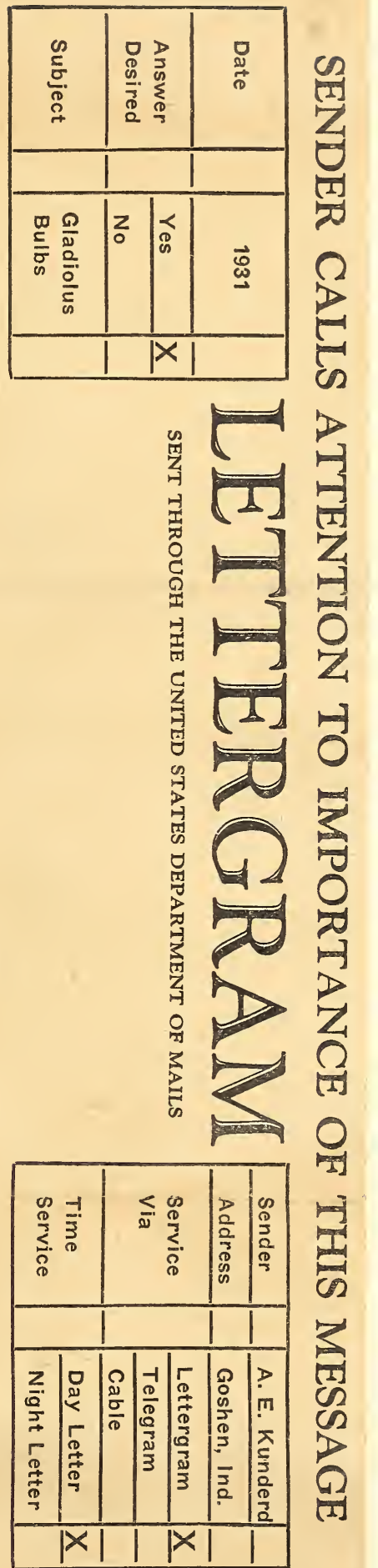

œ.

एक मे

D. C ct

म. $ए$ क स.

एक ट ह

00 'ot

ct to 0

0 . $\mathrm{H}_{\mathrm{CH}}$

$\rightarrow 0$ th

th

0 D

- pos

Q00 ct $Q$

H H

(1)

C. 0

F

ti

H. H

co

01

(D)

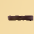




\section{Things You May Have Overlooked}

HIGHLIGHTS OF MY 1931 CATALOG

1. Special Rewards for Early Orders (Discounts up to $18 \%$ ), page 12 .

2. Special Collection Offers on pages $15,21,30,35,47,74,75,81$.

3. Color Illustrations of World's Finest Gladioli, pages 1, 17, 18, 51, $52,53,54,87,88,105$.

4. Kunderd's Flower Seed Department, page 90.

5. "Why Kunderd Gladioli Stand Supreme," page 2.

6. Endless Uses of Gladioli, page 5.

7. World's Recognition of Kunderd Gladioli, page 9.

8. How to Plant and Care for Gladioli, page 86.

9. General Listings of World's Foremost Gladioli, pages 14 to 85 inclusive.

10. Kunderd's Famous Gladioli in Mixture, pages 84 and 85.

It will be of great benefit to again refer to these pages. 


\section{SPECIAL NOTICE!}

All myGladiolus prices slashed $25 \%$ Discount, or $1 / 4$ OFF on all my Retail Gladiolus Prices up to March 1, 1931.

Disregard Catalog and Lettergram Discounts A. E. KUNDERD 



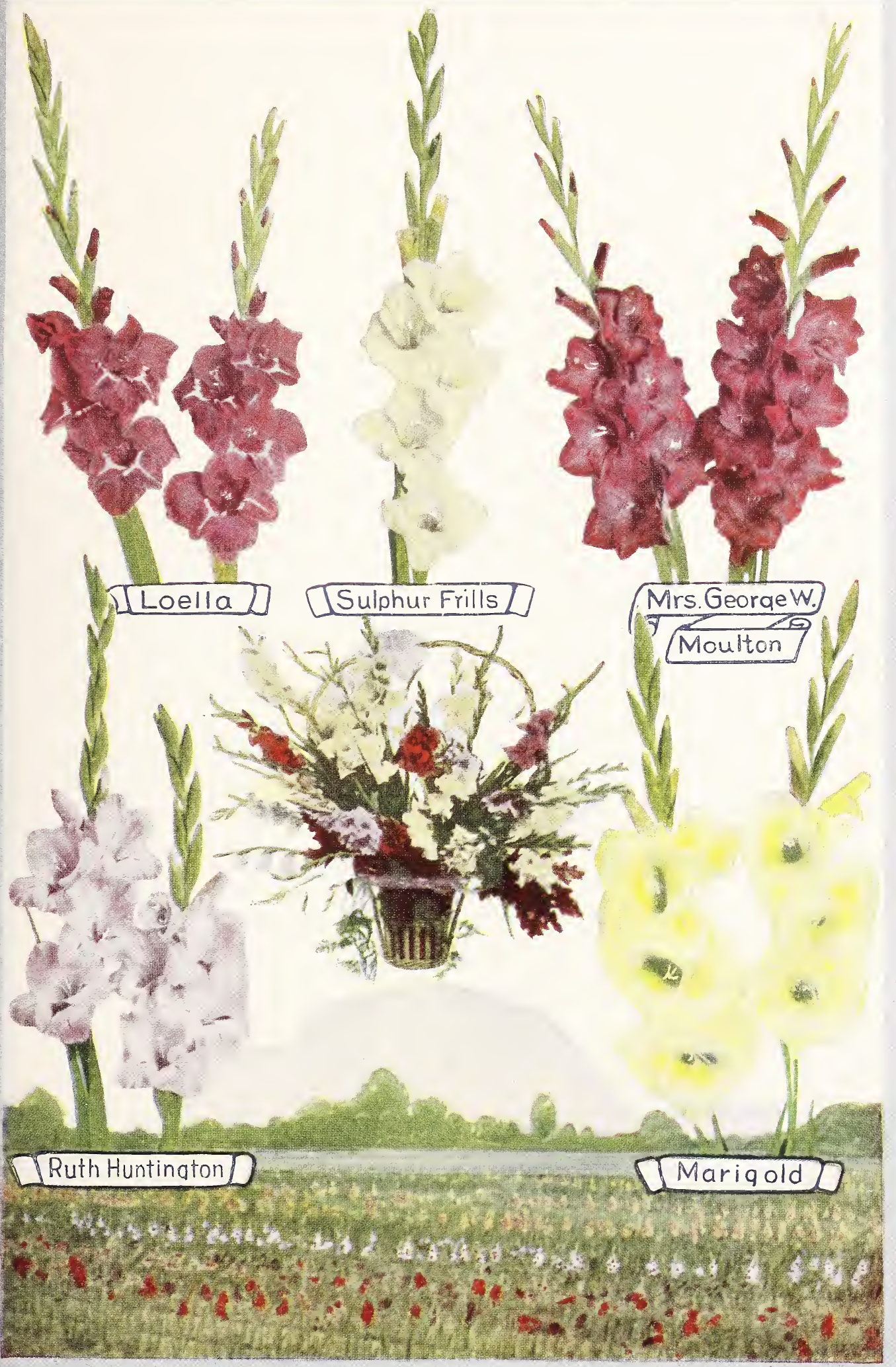


